\title{
Late Moscovian terrestrial biotas and palaeoenvironments of Variscan Euramerica
}

\section{Editors: C.J. Cleal $^{1,{ }^{*}}$, S. Opluštil ${ }^{2}$, B.A. Thomas $^{3}$ \& Y. Tenchov ${ }^{4}$}

With contributions from (in alphabetic order): 0.A. Abbink ${ }^{5}$, J. Bek ${ }^{6}$, T. Dimitrova ${ }^{4}$, J. Drábková7 ${ }^{\text {, Ch. Hartkopf-Fröder }}{ }^{8}$, T. van Hoof ${ }^{5}$, A. Kędzior ${ }^{9}$, E. Jarzembowski ${ }^{10}$, K. Jasper ${ }^{8}$, M. Libertinn ${ }^{11}$, D. McLean ${ }^{12}$, M. Oliwkiewicz-Miklasinska ${ }^{9}$, J. Pšenička $^{13}$, B. Ptak ${ }^{14}$, J.W. Schneider ${ }^{15}$, S. Schultka ${ }^{16}$, Z. Šimůnek ${ }^{7}$, D. Uhl ${ }^{17}$, M.I. Waksmundzka ${ }^{18}$, I. van Waveren ${ }^{19}$ \& E. L. Zodrow ${ }^{20}$.

1 Department of Biodiversity \& Systematic Biology, National Museum Wales, Cardiff CF10 3NP, UK.

2 Faculty of Sciences, Charles University in Prague, Albertov 6, 12843 Praha 2, Czech Republic.

3 Institute of Biological, Ecological and Rural Sciences, Aberystwyth University, Llanbadarn Fawr, Aberystwyth SY23 3AL, UK.

4 Geological Institute, Bulgarian Academy of Sciences, G. Bonchev Street Block 24, 1113 Sofia, Bulgaria.

5 TNO, P.0. Box 80015, 3508 TA Utrecht, the Netherlands.

6 Department of Palaeobiology \& Palaeoecology, Institute of Geology, Academy of Sciences of the Czech Republic, Rozvojová 269, 16500 Praha 6, Czech Republic.

7 Czech Geological Survey, Klárov 131/3, 11821 Praha 1, Czech Republic.

8 Geologischer Diest NRW, De-Greiff Straße 195, D-47803 Krefeld, Germany.

9 Institute of Geological Sciences, Polish Academy of Sciences, Kraków Research Centre, Senacka1, 31-002 Kraków, Poland.

10 Maidstone Museum, St Faith's Street, Maidstone ME14 1LH, UK.

11 National Museum, Václavské nám stí 68, 11579 Praha 1, Czech Republic.

12 MB Stratigraphy Ltd, 11 Clement Street, Sheffield S9 5EA, UK.

13 Palaeontology Department, West Bohemian Museum in Plzeň, Kopeckého sady 2, 30136 Plzeň, Czech Republic.

14 Institute of Geological Sciences, Polish Academy of Sciences, Upper Silesian Branch, Sosnowiec, Poland.

15 Department of Palaeontology, Geological Institute, Technische Universität Bergakademie Freiberg, Bernard-von-Cotta Straße 2, 09599 Freiberg, Germany.

16 Forschungsinstitut Museum für Naturkunde, Invalidenstraße 43, D-10115 Berlin, Germany.

17 Forschungsinstitut und Naturmuseum Senckenberg, Frankfurt am Main, Germany.

18 Institute of Geological Sciences, Polish Academy of Sciences, Warsaw, Poland.

19 Naturalis, P.0. Box 9517, 2300 RA Leiden, the Netherlands.

20 Palaeobotanical Laboratory, Cape Breton University, Sydney NS, Canada B1P 6L2.

* Corresponding author. Email: chris.cleal@museumwales.ac.uk.

Manuscript received: December 2009; accepted December 2009

\section{Abstract}

A synthesis of the upper Moscovian sedimentological and palaeontological record of terrestrial habitats across the Variscan foreland and adjacent intramontane basins (an area which is referred to here as Variscan Euramerica) suggests a contraction and progressive westward shift of the coal swamps. These changes can be correlated with pulses of tectonic activity (tectonic phases) resulting from the northwards migration of the Variscan Front. This tectonic activity caused disruption to the landscapes and drainage patterns where the coal swamps were growing, which became less suitable to growth of the dominant plants of the swamps, the arborescent lycopsids. They were progressively replaced by vegetation dominated by marattialean ferns, which through a combination of slower growth and larger canopies resulted in less evapo-transpiration. This in turn caused localised reductions in rainfall, which further affected the ability of the lycopsids to dominate the swamp vegetation. These changes were initially 
localised and where the coal swamps were able to survive the lycopsids and pteridosperms show little change in either species diversity or biogeography, indicating that at this time there was minimal regional-scale climate change taking place. By Asturian times, however, the process had accelerated and the swamps in Variscan Euramerica became progressively replaced by predominantly conifer and cordaite vegetation that favoured much drier substrates. Except in localised pockets in intramontane basins of the Variscan Mountains, the last development of coal swamps in Variscan Euramerica was of early Cantabrian age. Further west, lycopsid-dominated coal swamps persisted for a little longer. The last remnants of the lycopsid-dominated coal swamps in the Illinois Basin disappeared probably by middle-late Cantabrian times, as the cycle of contracting wetlands and regional reductions in rainfall generated its own momentum, and no longer needed the impetus of tectonic instability. This tectonically-driven decline in the Euramerican coal swamps was probably responsible for an annual increase in atmospheric $\mathrm{CO}_{2}$ of $\mathrm{c}$. $0.37 \mathrm{ppm}$, and may have been implicated in the marked increase in global temperatures near the Moscovian - Kasimovian boundary, and the onset of the Late Pennsylvanian interglacial.

Keywords: Pennsylvanian Subsystem, Climates, Vegetation, Faunas, Sedimentology

\section{Introduction}

Pennsylvanian (late Carboniferous) coal deposits have had a profound effect on mankind. They were the main energy resource that powered the Industrial Revolution, which in turn was the impetus for the development of modern western society. In recent decades, oil and gas have tended to replace coal as our main source of energy in the west, but there can be little doubt that our energy-intense life-styles had their origins in the $19^{\text {th }}$ and early $20^{\text {th }}$ centuries' coal bonanzas. Moreover, the increasing price and scarcity of oil is starting again to bring coal back into the energy equation, not only in the west but also in the rapidly growing Asian economies, notably of China and India.

In recent years it has become evident that these coal deposits may also be important to us in another, less direct way. We are now living in what has become known as an 'ice-house' world, where relatively low levels of atmospheric $\mathrm{CO}_{2}$ have restricted global temperatures and allowed significant quantities of ice to build up at both poles. Such conditions are not unique, with at least six earlier ice-ages having been recognised during Earth's 4.5 Ga history (Frakes et al., 1992). But such cool intervals are not the norm; at least during the Phanerozoic Eon, 'greenhouse' conditions with relatively high global temperatures have existed for some $90 \%$ of the time. Moreover, the present-day is unusual because of the role that land vegetation is playing in helping control atmospheric compositions, a role that has only been possible since Devonian times, when plants have come to dominate the landscape. There is in fact only one other time in Earth's history when there were both comparable levels of polar ice and widespread vegetation, especially in the tropics, and that was the Pennsylvanian Subperiod (Cleal \& Thomas, 2005; DiMichele et al., 2009). Consequently, the only independent (i.e. pre-Pleistocene) data that we have available to test if climate-atmosphere-biosphere models are robust for predicting future trends is that obtained from the Pennsylvanian geological record (DiMichele et al., 1996a, 2001, 2009; Cleal \& Thomas, 2005).

The coals were the result of widespread wetland vegetation (often referred to as the coal swamps) that was dominated by arborescent lycopsids (DiMichele, \& Phillips, 1985, 1994; Phillips et al., 1985; Phillips, \& DiMichele, 1992). The long history of commercial exploitation of the coals has meant that there is an almost equally-long history of scientific investigation into them and their associated rocks and fossils. Extensive historical data sets are therefore available, which should allow detailed analyses of Pennsylvanian biotic and palaeoenvironmental changes within the coal swamps. However, previous efforts to integrate these datasets have been less than successful for a range of reasons: national differences in palaeontological taxonomy, taxonomic subjectivity when one specialist has attempted to synthesise the data, and a failure to compare data from different disciplines.

There have lately been attempts to overcome these problems through international collaborative projects. One such project looked at the beginning of the coal swamps in Bashkirian and early Moscovian times (Eble, 2004). In 2003, a second project was initiated under the auspices of the International Geological Correlation Programme (IGCP) to look at the dramatic contraction and change in composition of the swamps that took place in Euramerica towards the end of the Moscovian Age (Cleal, 2004, 2008a; Jarzembowski, 2007). This change to the swamps is of particular interest as it appears to have coincided with marked global climatic warming that has been identified in both the southern (Gondwana) and northern (Angaran) middle to high palaeolatitudes (Meyen, 1982; Gonzalez, 1990; Durante, 1995; Fielding et al., 2008). As pointed out by DiMichele et al. (2009), however, establishing that two events are correlated does not necessarily mean that one caused the other - what they term the 'conflation of correlation with causation.' Moreover, even if there is a causal link, it is not always clear what caused what in such a situation; uniformitarian comparisons of events in Palaeozoic times with today's very different biotas and environments (so-called 'actualistic models') are potentially very misleading.

IGCP 469 aimed to throw light on this problem by establishing in more detail the pattern and timing of the change to the Euramerican coal swamps in late Moscovian times. It brought together a team of stratigraphers, sedimentologists, 
palaeobotanists, palynologists and palaeozoologists from across Europe and eastern North America. Twice-yearly meetings were held at various centres across the study area (Table 1) allowing regular interaction and discussions between the specialists, as well as providing opportunities for visiting exposures and collections in the different countries. The original proposal drew interest from 39 specialists in 11 countries, but as the project progressed this was distilled down to 30 active participants from 9 countries. The scope of the project also rapidly became more focussed. Originally, the intention had been to cover all of Euramerica but, for a combination of practical reasons, the remit became narrowed to the Variscan foreland between the Canadian Maritimes and Dobrudzha in north-eastern Bulgaria, together with the adjacent intramontane basins associated with Saar-Lorraine and the Bohemian Massif. This area, which we have termed Variscan Euramerica (Fig. 1), was one of the largest areas of coal swamps of Moscovian age and has one of the most extensive geological data sets that can be brought to bear on the problem. Moreover, there is now an active community of geologists and palaeontologists in this region that is interested in the Moscovian Stage, some of whom have been willing to come together in a collaborative project of this nature.

This extended paper represents the final report of IGCP 469. In order to keep-up momentum during the five years of the project, we have progressively been publishing the results of our work and there have been collections of papers published in the journals Geologica Balcanica (vol. 34, parts 1-2, 2004), Zeitschrift der Deutschen Gesellschaft für Geowissenschaften
Table 1. IGCP 469 meetings.

\begin{tabular}{lll}
\hline Date & Venue & Coal Basin \\
\hline August 2003 & Utrecht, the Netherlands & \\
April 2004 & Sofia, Bulgaria & Dobrudzha and Svoge \\
October 2004 & Freiberg, Saxony, Germany & Zwickau \\
April 2005 & Cardiff, UK & South Wales, Radstock \\
June 2005 & Halifax NS, Canada & Canadian Maritimes \\
October 2005 & Bucharest, Romania & Reşiţa, Sirinia \\
May 2006 & Kraków, Poland & Upper Silesia \\
September 2006 & Prague, Czech Republic & Central Bohemia \\
April 2007 & Birmingham, UK & Pennines \\
October 2007 & Leiden, the Netherlands & Limburg \\
\hline
\end{tabular}

(vol. 156, part 3, 2005), Geological Magazine (vol. 144, part 3, 2007), and Studia Geologica Polonica (vol. 129, 2008). However, the current report will draw together the various themes that have been investigated in these papers and present a holistic view of the changes that appear to have taken place in Variscan Euramerica during late Moscovian times.

\section{Statement of the problem}

That there was a major change in Euramerican terrestrial habitats in late Moscovian times was first suggested by White \& Thiessen (1913), based on a combination of macrofloral and stratigraphical evidence. However, the model became more fully developed in the 1980 s mainly through work in the

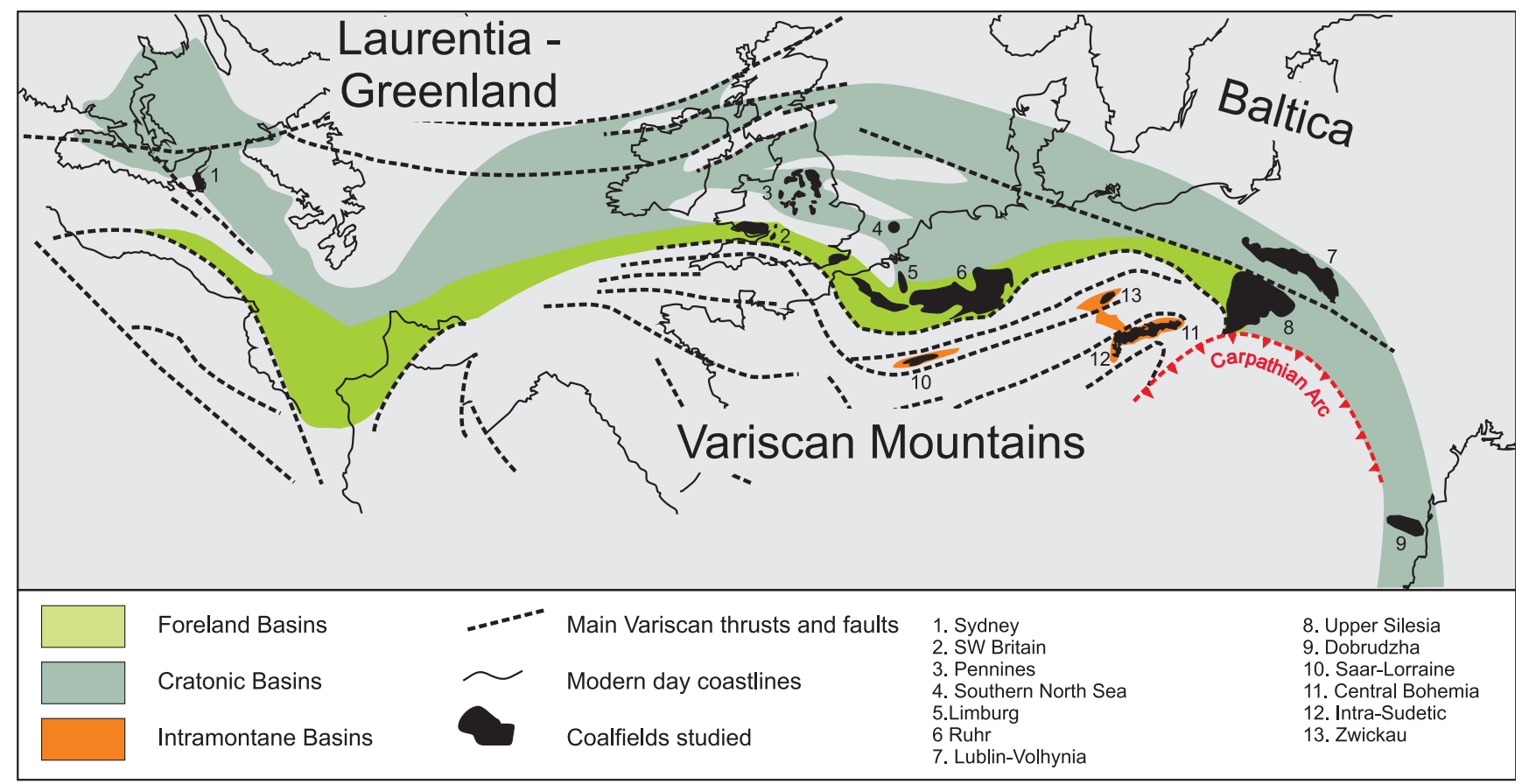

Fig. 1. The palaeogeography of Variscan Euramerica showing areas where coal swamps developed during late Moscovian (late Westphalian - earliest Stephanian) times. Using a similar approach to that used by Cleal \& Thomas (2005) this is an attempt to show the total area where the swamps developed rather than just where their remains are preserved today, or areas where there are terrestrial deposits but no coals. Based on maps by Ziegler (1990), Stampfli \& Borel (2004), Wagner (2004), Glennie (2005) and Opluštil \& Cleal (2007). 
Illinois and Appalachian coal basins, where various data sets were integrated and which suggested marked differences in depositional conditions and vegetation between the Middle and Upper Pennsylvanian parts of the succession (Phillips \& Cecil, 1985). It was concluded that the observed changes were a consequence of climate change and the evidence does seem to suggest differences in rainfall patterns between Middle and Late Pennsylvanian times. However, the change in the vegetation reported by Phillips and his co-workers was very abrupt, with no evidence of significant change in the run-up to the Middle - Upper Pennsylvanian boundary (Phillips, 1981; Phillips et al., 1985; DiMichele et al., 1985; DiMichele \& Phillips, 1995, 1996a). It was explained that this was a consequence of the community structure of the swamp vegetation, which allowed them to withstand considerable environmental stress before undergoing significant change (DiMichele \& Phillips, 1995; DiMichele et al., 1996a, 2001). Only when the so-called 'framework ecomorphic species' were lost - the arborescent lycopsids - did the swamp community collapse and become replaced by a quite different type of tree-fern and seed-plant dominated vegetation.

The problem with this scenario is that it was based mostly on data from coal balls and coal palynology, which mainly reflect the vegetation of areas of peat substrates within the coal swamps. This swamp vegetation, with its unusual plants adapted to extreme environments (DiMichele \& Phillips, 1994) probably did have an intrinsic robustness to extrinsic environmental stress. Consequently, changes in this vegetation would be a poor proxy for extrinsic environmental change, such as climate change. The clastic-substrate vegetation preserved in the adpression macrofloras, although representing a relatively small part of the coal swamps, was less insulated from the vegetation of the areas surrounding the swamps and would thus be more likely to change in response to environmental change. Although some of the later papers attempted to incorporate data from the adpression record (e.g. DiMichele et al., 1996a), this was based on a number of poorly-documented American floras, together with a rather generalised analysis of American and European records by Pfefferkorn \& Thompson (1982).

Much of the American coal ball data came from the Interior Coalfields, notably the Illinois Basin. This was an essential stable, cratonic, coastal area subjected to repeated marine incursions and, although yielding beautifully-preserved coalball floras, represented a rather different habitat to most of the other Euramerican coal basins. Covering an area of perhaps $1-2 \times 10^{5} \mathrm{~km}^{2}$ the coals of the Interior Coal Basin have been interpreted as the 'largest tropical peat mires in Earth history' (Greb et al., 2003) but as we will show in this report this is only a fraction of the overall area of coal swamps in Variscan Euramerica at their maximum. It was assumed that the vegetation patterns observed in Illinois could be generalised across Euramerica (e.g. DiMichele et al., 2009, p. 205) but no real justification for this assumption has been given.
This has been further complicated because of problems of correlating the American and European upper Moscovian sequences, making it difficult to compare the changes in biotas and habitats in the two areas. The mis-correlation of the Westphalian-Stephanian stage boundary with the DesmoinesianMissourian boundary in the North American sequences continues to appear in the literature; the WestphalianStephanian boundary in fact correlates with a level in the middle Desmoinesian (Wagner, 1984; Wagner \& Winkler-Prins, 1985; Cleal et al., 2003). There is also the continuing debate as to whether or not there is a stratigraphical break at the Desmoinesian-Missourian (Moscovian-Kasimovian) boundary in the American sequences. Internal correlation within the USA, especially of the marine bands, seems to suggest that there is no significant break here (e.g. Heckel, 2008). However, a comparison of the macrofloras from just above and below the Desmoinesian-Missourian boundary with the European macrofloral biostratigraphy suggests a substantial time gap (Wagner \& Lyons, 1997); this is equivalent in the Spanish succession, which has the most complete Stephanian succession in Europe, to some $6 \mathrm{~km}$ thickness of strata (R.H. Wagner, pers. comm., 2009). In some American basins there is some physical evidence of a break in the sequence here (e.g. Heckel, 1991; Peppers, 1996; Wagner \& Lyons, 1997; Pfefferkorn et al., 2008) and although there has been some debate as to the size of stratigraphical break (e.g. Eagar \& Belt, 2003), even a small break would make any change in vegetation at about this time appear more abrupt than it really was. Clearly this needs to be resolved by improved biostratigraphical analyses of the American biotas, especially the macrofloras, and is beyond the scope of this report.

In order to gain a better understanding of events at and about the Moscovian-Kasimovian boundary, we clearly need to obtain additional data relating to the non-swamp habitats of Euramerica, preferably from basins of more representative habitats. The Appalachian Basin would potentially be an important source of data but, despite a number of biostratigraphical studies (the most important by Blake et al., 2002) the macrofloras from there remain very poorly documented. The present study has therefore focussed mainly on the Variscan foreland that stretched from the Canadian Maritimes across western and central Europe to the Black Sea, which was one of the largest areas of coal swamp in Euramerica. This has been complemented by data from the immediately adjacent intramontane basins of Central Bohemia and adjacent areas, and Saar-Lorraine.

In this report, we start by summarising the stratigraphical and sedimentological evidence from the key basins in Variscan Euramerica. Against this background, we will then examine a number of the major groups of fossils found in these deposits (macrofloras, palynology, insects and spiders) to see what evidence their distribution provides of changing environments of the time. The study focuses on the upper part of the Moscovian 
Stage, as defined in the IUGS Global Chronostratigraphy for the Carboniferous System (Heckel \& Clayton, 2006). For practical reason, however, it is still normal in Variscan Euramerica to use the Carboniferous stages and substages of the Heerlen Regional Chronostratigraphy (see Wagner, 1974 for a historical review of this classification, although it should be noted that what were in 1974 called series and stages have subsequently been demoted to stages and substages). In this Heerlen classification, the interval being covered in this report belongs to the Bolsovian and Asturian substages of the Westphalian Stage and the Cantabrian Substage of the Stephanian Stage (Fig. 2).

\begin{tabular}{|c|c|c|c|}
\hline \multicolumn{2}{|c|}{ IUGS Global Chronostratigraphy } & \multicolumn{2}{|c|}{ 'Heerlen' Regional Chronostratigraphy } \\
\hline Series & Stages & Stages & Substages \\
\hline \multirow{4}{*}{$\begin{array}{c}\text { Upper } \\
\text { Pennsylvanian }\end{array}$} & Gzhelian & Autunian & \\
\hline & \multirow{3}{*}{ Kasimovian } & \multirow{4}{*}{ Stephanian } & Stephanian C \\
\hline & & & Stephanian B \\
\hline & & & Barruelian \\
\hline \multirow{3}{*}{$\begin{array}{c}\text { Middle } \\
\text { Pennsylvanian }\end{array}$} & \multirow[b]{3}{*}{ Moscovian } & & Cantabrian \\
\hline & & \multirow{4}{*}{ Westphalian } & $\begin{array}{c}\text { Asturian / } \\
\text { Westphalian D }\end{array}$ \\
\hline & & & Bolsovian \\
\hline \multirow{5}{*}{$\begin{array}{c}\text { Lower } \\
\text { Pennsylvanian }\end{array}$} & \multirow{5}{*}{ Bashkirian } & & Duckmantian \\
\hline & & & Langsettian \\
\hline & & \multirow{3}{*}{$\begin{array}{l}\text { Namurian } \\
\quad \text { (pars) }\end{array}$} & Yeadonian \\
\hline & & & Kindersencoutian \\
\hline & & & $\begin{array}{c}\text { Alportian } \\
\text { Chokierian (pars) }\end{array}$ \\
\hline
\end{tabular}

Fig. 2. The relationship between the IUGS global chronostratigraphy and the Heerlen regional chronostratigraphy for the Pennsylvanian Subsystem. The grey-shaded area represents that part of the interval that is covered by IGCP 469. The area shaded with oblique lines represents the uncertainty as to the position of the Bashkirian-Moscovian boundary (see Kullmann et al., 2007).

\section{Basins Studied (S. Opluštil \& A. Kędzior)}

Pennsylvanian strata of of Variscan Euramerica were deposited in basins established either at the end of Early Palaeozoic or during Late Palaeozoic times. In both cases, their tectonosedimentary histories were significantly affected by the Variscan Orogeny. This orogeny was a consequence of an oblique (dextral) continental collision between the southern margin of the Old Red Continent (Laurussia and Avalonia) and the north edge of Gondwana, together with intercalated small plates of Armorican/Iberian affinity (Ziegler \& Dèzes, 2006; Franke, 2000, 2006; Pharaoh et al., 2006; Winchester et al., 2006). This collision resulted in the W-E striking Central Pangaea Mountains, of which the Variscan Mountains formed a major component, and which followed the line of the Carboniferous palaeo-equator (Ziegler et al., 1997). Basins developed along both sides of this mountainous belt as well as within the orogenic belt itself (intramontane basins). Depending on their geotectonic position within the zones of various intensity and character of the Variscan deformation processes (0pluštil \& Cleal, 2007), the Late Palaeozoic basins of Europe can be broadly divided into three groups: (1) cratonic or pericratonic basins, (2) foreland basins and (3) fault related, intramontane basins (Fig. 1).

\section{Cratonic basins}

Coal-bearing strata occur on the cratonised northern part of the foreland, which was composed of terranes amalgamated in pre-Variscan times (in Early Palaeozoic or even earlier times). The basins that developed on this stabilised basement are referred to as the cratonic or pericratonic basins. At least in Britain they were initiated as a result of a combination of Viséan lithospheric stretching, Namurian rifting and compressional intra-plate stress (Kombrink et al., 2008). Orogenic processes tended to have little effect on the cratonic basins and so their strata are typically horizontal to subhorizontal, and mostly disrupted only by normal faults. Reverse faults and folds are less common, except in some pericratonic basins located along the craton margin and affected by adjacent Variscan processes (e. g. Lublin- Volhynia Basin along the Polish-Ukraine border). Coal rank in the cratonic basins is typically low to medium. Palaeogeographically, these basins occupied large coastal to near-coastal lowlands, and underwent frequent marine incursions during glacial minima. Slow and even thermal subsidence allowed the development of glacio-eustatically driven cyclothems (e.g. Gibling \& Bird, 1994). There are also glacio-eustatically driven marine bands that are widespread and can be correlated across western Europe and North America (e.g. Calver, 1968, 1969; Bless et al., 1977; Ramsbottom et al., 1978).

These basins have many features in common, in particular a progressing regressive trend that continued until early Stephanian times, and is related to Variscan uplift (Dreesen et al., 1995). Because of this trend, the depositional environments in these basins grade from shallow marine, through coastal delta plain to fluvial, and alluvial setting.

\section{Sydney (E.L. Zodrow)}

The Carboniferous Canadian Maritimes Basin was initiated after the Devonian Acadian Orogeny, which is contemporary with the latest stage of the Caledonian Orogeny in Europe. The sedimentary characteristics and nature of deposition of the Carboniferous Maritimes Basin were shaped by continuing tectonic activity in the area, which persisted to Permian times in the various parts of the Appalachian Orogen. Sediment entered the Basin from both local sources (e.g. Precambrianage granite of the Cape Breton Highlands) and the Appalachian Basin. The result was that a thick sedimentary blanket of Late Devonian to Early Permian age covered an area of approximately $150,000 \mathrm{~km}^{2}$ of New Brunswick, Nova Scotia, Prince Edward Island, and parts of south-western Newfoundland (Fig. 3b). 


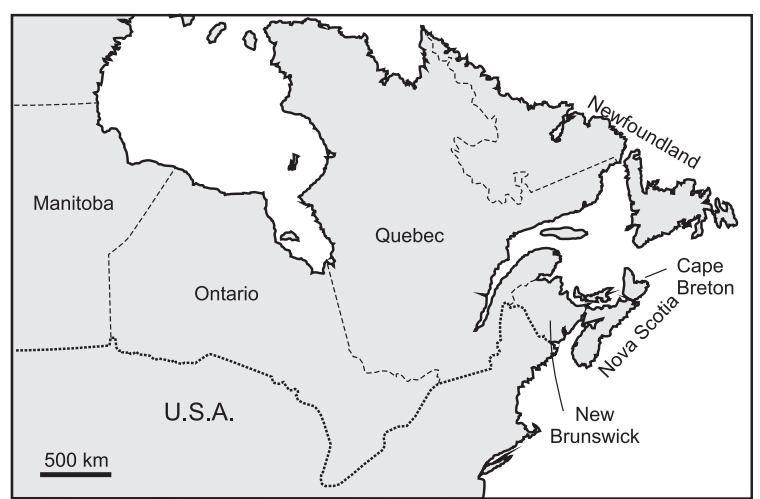

a.

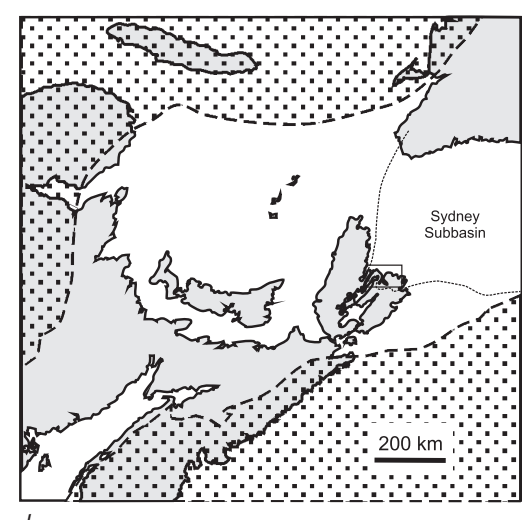

b.
Fig. 3. The Sydney Coalfield, Cape Breton Island, Canada. a. General map of eastern Canada showing location of Cape Breton; b. Western and central part of the Carboniferous Canadian Martimes Basin, showing position of the Sydney Sub-basin; rectangle outlines are shown in geological map (c); c. Generalised geological map of the Sydney Coalfield, the on-shore part of the Sydney Sub-basin, showing the geographical distribution of the three Pernnsylvanian formations. Re-drawn partly from Gibling \& Bird (1994) and Marchioni et al. (1996).

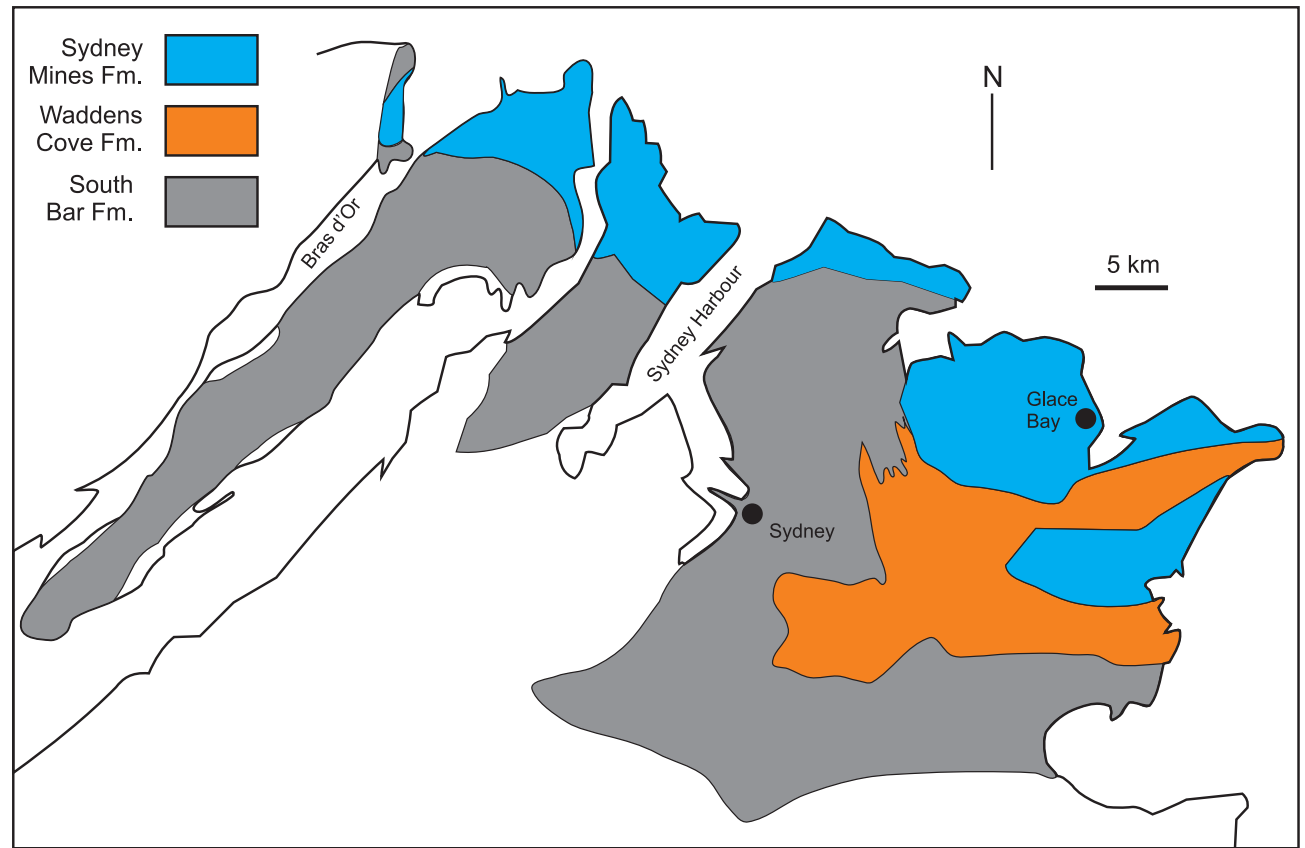

c.
The Sydney (Sub-)Basin is a $450 \mathrm{~km}$ long fault-bounded depression within the Canadian Maritimes Basin, extending between Cape Breton and Newfoundland (Fig. 3b). It has a Carboniferous succession about $1.2 \mathrm{~km}$ thick, including marine and terrestrial Mississippian deposits (Windsor and Mabou Groups) and a coal-bearing Pennsylvanian sequence (Morien Group). The Morien Group is essentially non-marine (e.g. Vasey \& Zodrow, 1983; Zodrow, 1991), although there is evidence of marine influence in the far east of the coalfield (Wightman, et al., 1994). There is also an overlying red-bed sequence (Pictou Group) that is also probably of Pennsylvanian age, although it is only known from boreholes. The subsidence that allowed the Morien Group sediments to accumulate has been linked to orogenic activity (Pascucci et al., 2000).

Although there has been a significant increase recently in knowledge about the off-shore portion of the Sydney Basin (Pascucci et al., 2000), much of our knowledge of the Morien Group comes from work on the on-shore part of the basin, known as the Sydney Coalfield (Fig. 3c; see Calder, 1998 for a historical review). In particular, the spectacular cliff sections along this stretch of coast have been the subject of a series of recent studies on the sedimentology and coal petrography (Gibling \& Bird, 1994; White et al., 1994; Marchioni et al., 1996; Tandon \& Gibling, 1997; Gibling et al., 2004).

The Morien Group of the Sydney Coalfield is divided into three formations in ascending stratigraphical order, following Boehner \& Giles (1986) (Fig. 4).

1. South Bar Formation. Grey and sometimes pebbly sandstones, with rare conglomerates, mudstones and thin coals.

2. Waddens Cove Formation. Red and grey siltstones, mudstones and sandstones, with some calcretes and thin coals.

3. Sydney Mines Formation. Mainly grey mudstones, siltstones and shales, with some coals and thin red mudstones. Also present are some diagenetic carbonates, non-marine limestones, and thick coals.

The Sydney Basin underwent rapid sedimentation and shallow burial from 320 to $290 \mathrm{Ma}$ (based on age of coalification - Ryan et al., 1991). As a result, diagenetic effects are generally minimal (maturity levels are between $0.65 \%$ and $0.70 \%$, as measured by 


\section{Sydney Coalfield}

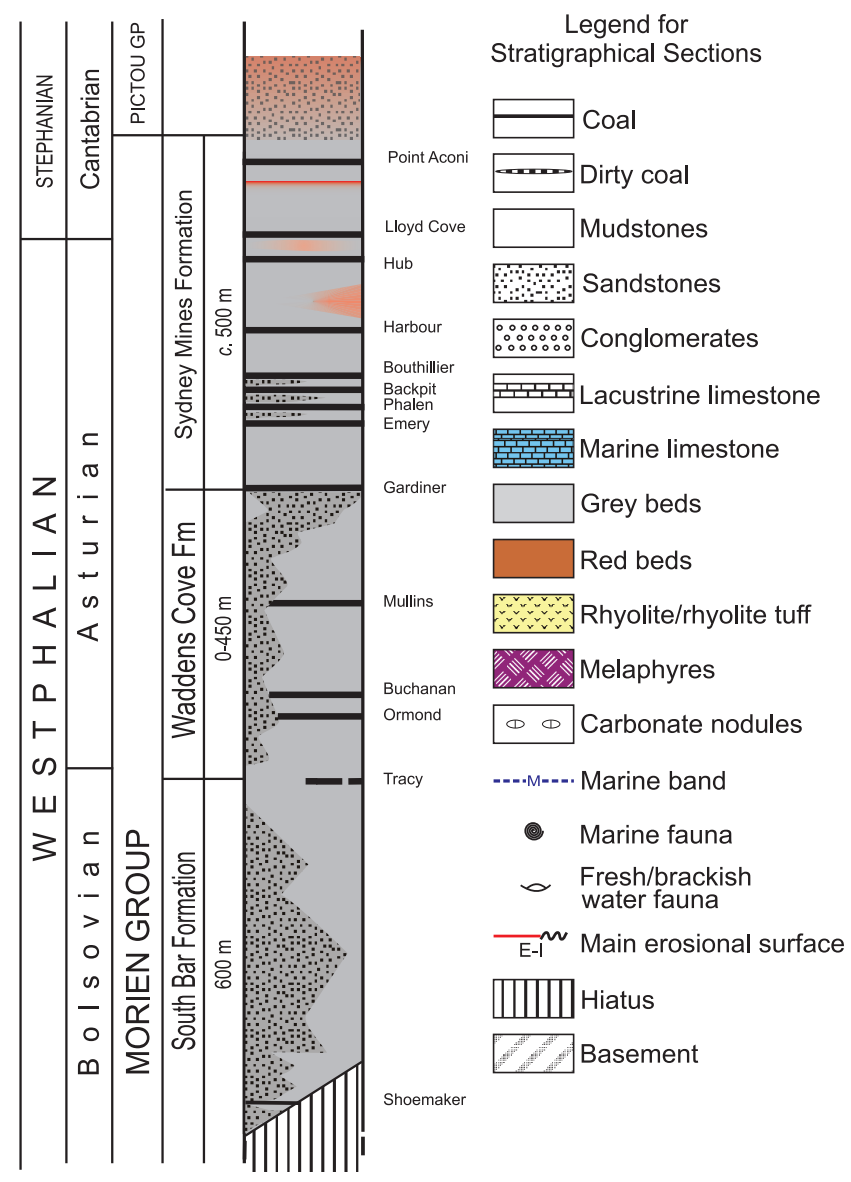

Fig. 4. Stratigraphy of the Morien Group, Sydney Coalfield, Cape Breton, based on data in Boehner \& Giles (1986), Gibling \& Bird (1994) and Gibling et al. (2004). Also showing the proposed positions of the substage boundaries based on the macrofloras and palynology (Zodrow \& Cleal, 1985; Cleal et al., 2003).

vitrinite reflectance, but nevertheless increase with depth of sediment burial - Calder, 1998) and this favoured exceptional preservation of cuticles, pollen and spores.

\section{Pennines (S. Opluštil \& A. Kędzior)}

The Pennine Basin covers approximately $67,700 \mathrm{~km}^{2}$ between the Wales-London-Brabant High and the Southern Uplands of Scotland (Fig. 5), and has resulted in unfolded and subhorizontally lying coal-bearing Pennsylvanian strata covering vast areas of central and northern England. This basin represents only the western part of a much larger depocentre that extends east beneath the present-day North Sea and into continental Europe (Cope et al., 1992). Due to erosion and/or cover by post-Carboniferous deposits, coal-bearing strata of the Pennine Basin are divided into numerous separate coalfields. Correlation between them is based on marine and freshwater fauna bands. The Pennine Basin was separated from the Variscan foreland to the south (e.g. the South Wales Coalfield) by the

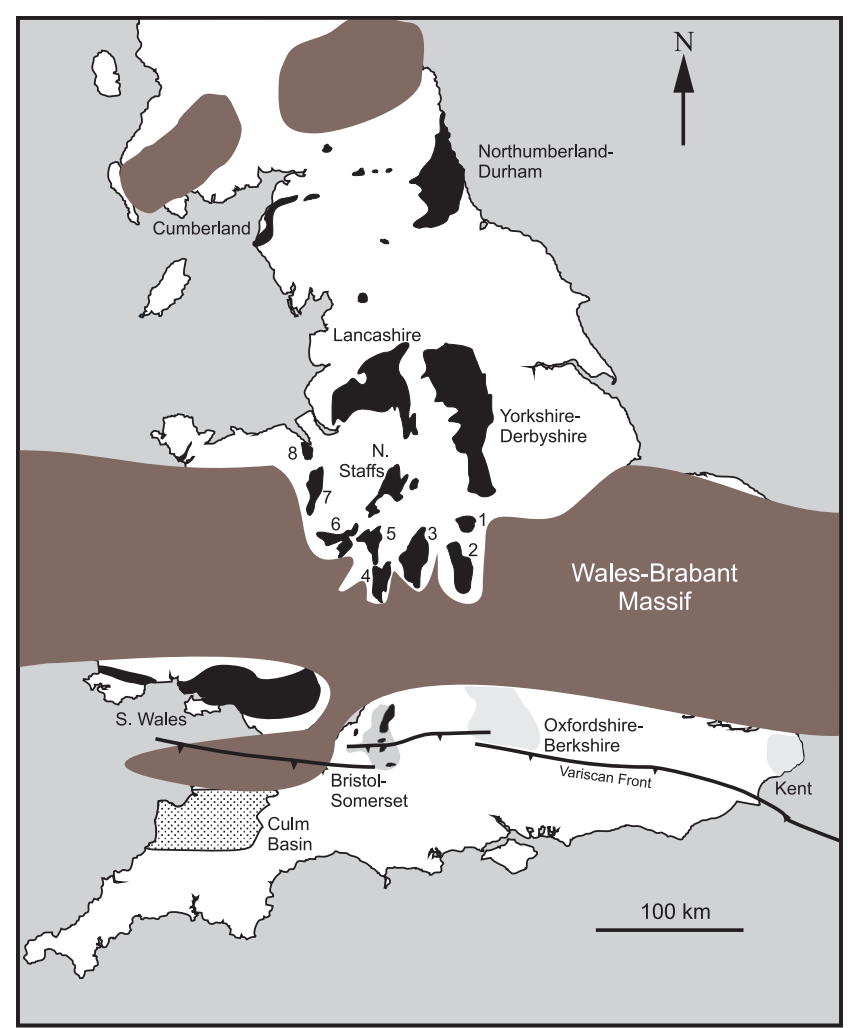

Fig. 5. Distribution of main coalfields in England and Wales, shown relative to the area of non-deposition known as the Wales-London-Brabant High. Exposed coalfields shown in black, concealed coalfields in grey, areas of non-deposition in brown, areas of marginal marine ('Culm' facies) deposition in fine stipple. For coalfields immediately north of the Wales-Brabant Massif: 1 = Leicestershire - S. Derbysire; $2=$ Warwickshire; $3=$ S. Staffordshire; $4=$ Wyre Forest $; 5=$ Coalbrookdale; $6=$ Shrewsbury; 7 = Denbigh $; 8=$ Flint . Adapted from Cleal $(2005,2007)$.

palaeohigh of the Wales-London-Brabant High, an orographic barrier caused by an underlying late Ordovician granitic body that existed throughout most of the Carboniferous Period (Cope et al., 1992; De Vos, 1997; Waters \& Davies, 2006), although it provided little clastic sediment to the Pennine Basin. Despite this physical barrier, the Namurian and most of the Westphalian deposits of both areas are similar in their lithological development, although they differ in the upper Westphalian and Stephanian parts of the basin-fill (see below). The lithostratigraphy used in this report (Fig. 6) mainly follows Powell et al. (2000) and Waters et al. (2007, 2009).

The Pennine Coal Measures Group is up to $1,900 \mathrm{~m}$ thick in the centre of the basin near Manchester but thins significantly to as little as $150 \mathrm{~m}$ near the basin southern margin, such as in the South Staffordshire Coalfield. Across most of the basin it rests conformably upon the Millstone Grit Group, but along the southern basin margin it oversteps the Millstone Grit and rests unconformably upon pre-Carboniferous rocks of the WalesLondon-Brabant High. The Millstone Grit as numerous marine bands and is mostly coal-barren, although discontinuous coals up to $0.8 \mathrm{~m}$ thick start to appear in the upper (Yeadonian) part. 
The lower part of the Lower Coal Measures consists of lower delta plain deposits including several marine or brackish-water bands (Guion \& Fielding, 1988; Guion et al., 1995). Typical are micaceous and/or feldspatic sandstones, many ganisters, and thin and discontinuous coal seams (up to $0.8 \mathrm{~m}$ thick) developed in planar mires (Aitkenhead et al., 2002). Sandstones show the same palaeocurrents from the north and northeast to those seen in the Millstone Grit (Chisholm et al., 1996; Hallsworth et al, 2000). Quartz arenitic sandstones are interpreted as shoreline and shallow-marine wave-reworked deltaic deposits (Fielding, 1984a; Waters \& Davies, 2006).

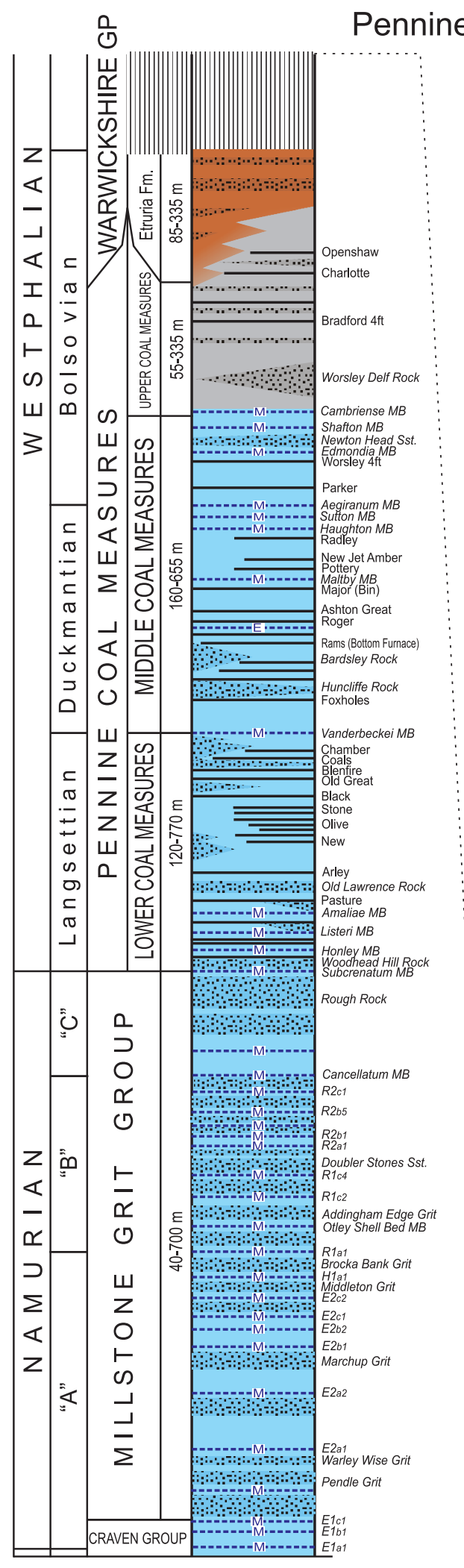

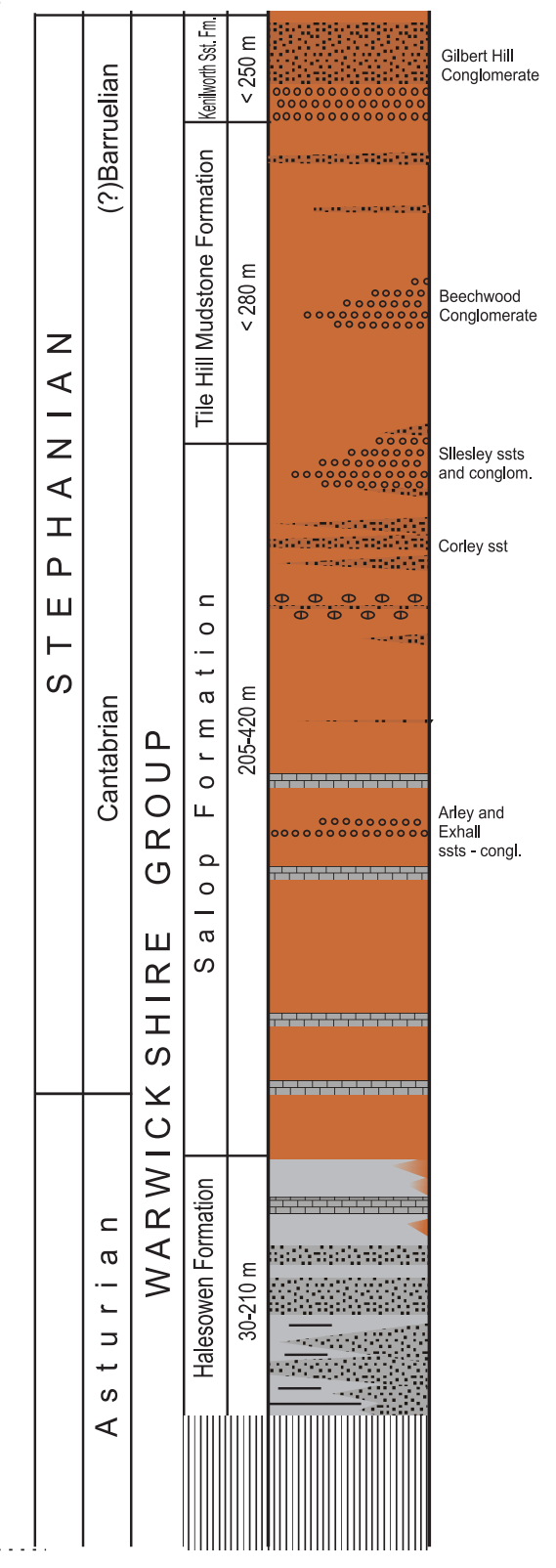

Fig. 6. Pennsylvanian stratigraphy of the central part of the Pennine Basin (Lancashire and Yorkshire coalfields), UK. Redrawn from Cleal (1997, 2005, 2007). For legend, see Fig. 4. 


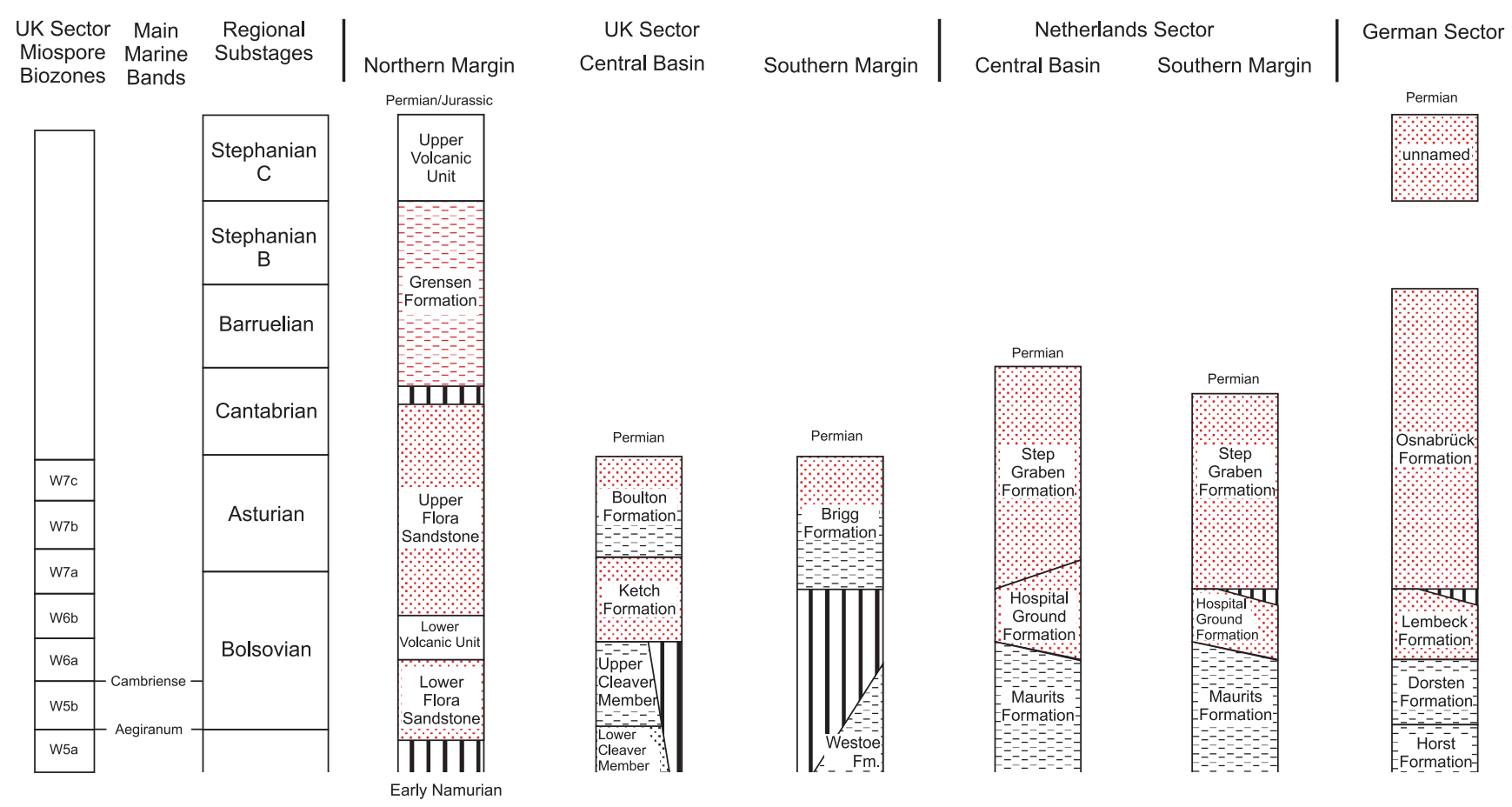

Fig. 7. Lithostratigraphical divisions of the upper Westphalian and Stephanian stages in the southern North Sea Basin. No vertical scale implied. Generalised lithofacies are indicated by shading as follows: grey = poorly-drained, coal measures facies; red = well-drained continental facies; stippling = sandstone dominated facies; dashes = mudstone dominated facies. The divisions used for the UK sector are based on Cameron (1993) and Besly (2005); those for the Netherland sector on Adrichem Boogaert \& Kouwe (1993), Collinson (1993) and Quirk (1993, 1997); and those for the German sector correspond to those used for the Ruhr Basin (see Schuster, 1968, Fabian, 1971, Lund, 2001).

The rest of the Lower Coal Measures and the Middle Coal Measures are dominated by mudstones with localised sandstone bodies, representing deposits of a lower to upper delta plain environment (Fielding, 1984a, 1984b, 1986, 1987; Guion \& Fielding, 1988; Guion et al., 1995; Rippon, 1996; Aitkenhead et al., 2002). The main distributary channels were up to $20 \mathrm{~m}$ thick and $10 \mathrm{~km}$ wide, and carried either micaceous sediment from the north; or greenish grey, weakly micaceous and clay-rich sediment from the west (Chisholm, 1990; Chisholm et al., 1996; Hallsworth and Chisholm, 2000). There are numerous persistent, thick coal seams, which are low in ash and sulphur, representing raised mires (Smith, 1962). Most of the workable coals are typically 1-3 m thick, but along the basin margins only a few but rather thick amalgamated coals occur due to a lower subsidence rate (e.g. the $17 \mathrm{~m}$ thick Thick Coal of South Staffordshire Fulton, 1987).

A new influx of sediment from the east and southeast appears in the upper part of the Middle Coal Measures, above the Maltby Marine Band (Halsworth \& Chisholm, 2000) and this came to dominate deposition in the Upper Coal Measures in the eastern part of the Pennines. This change in sediment source was probably associated with the advance of the Variscan fold-belt to the south (Evans et al., 2001). The Upper Coal Measures consists of braided fluvial deposits with medium- to coarsegrained sandstones packed into thick amalgamated bodies with internal erosional surfaces, thin coals, lacustrine sediments with estheriids, but no marine bands (Guion \& Fielding, 1988;
Guion et al., 1995). The thickness of this unit varies due to the erosion during early Asturian times (0pluštil \& Cleal, 2007).

The transition between the Coal Measures and the overlying Warwickshire Group is transitional and diachronous, occurring earlier in the southernmost part of the basin (Besly \& Turner, 1983). The Warwickshire Group consist mostly of clastic material derived from the rising Variscan Mountains to the south of Britain and are in effect a more distal equivalent of the Pennant Sandstone Formation of southwest Britain (Besly, 1988; Besly \& Cleal, 1997). The lower part of the group, the Etruria Formation, represent deposits of a well-drained alluvial floodplain, including purple, red, brown green and grey mottled mudstones with pedogenic horizons (Besly \& Turner, 1983; Besly, 1987, 1988; Besly \& Fielding, 1989; Glover et al., 1993, Waters and Davies, 2006). Subordinate lenticular sandstones and conglomerates contain an admixture of volcanic and lithic clasts. Thin coal seams are also locally present. The sediment was deposited during ever-wet climatic conditions, and their red colouration was the result of post-depositional oxidation in well-drained substrates (Besly \& Turner, 1983; Besly, 1987; Powell et al., 2000; Opluštil \& Cleal, 2007).

The rest of the Warwickshire Group lies unconformably on the Etruria Formation. Mostly they are red and red-brown inter-bedded mudstone and sandstone, with subordinate conglomerates representing well-drained alluvial plain environments with shallow lakes formed during drier (?semi-arid) climatic conditions (Waters \& Davies, 2006). However, one part 
of the grop, the Halesowen Formation, consists of grey-green micaceous sandstones and mudstones with thin coal seams, fresh-water spirorbid limestones, and palaeosols with pedogenic carbonates, indicating relatively high water table conditions (Besly \& Cleal, 1997; Cleal, 2005). There is only limited evidence as to the age of these higher parts of the Warwickshire Group, but macrofloras from the Halesowen Formation suggest a late Asturian age and from the Salop Formation a Cantabrian age (Besly \& Cleal, 1997; Cleal, 2005, 2008c).

\section{Southern North Sea (D. McLean)}

The Pennsylvanian southern North Sea Basin extends as an eastwards continuation of the British Pennine Basin (Maynard et al., 1997). Within the basin, Westphalian strata rest conformably upon Namurian deposits, but on the northern and southern basin margins they onlap older rocks of the Mid North Sea High - Ringkøbing - Fyn High and the Wales-London-Brabant High. To the east, the basin is continuous with the subsurface Carboniferous basins of the Netherlands and northern Germany. The basin is interpreted as the result of post-rift, passive, thermal subsidence of the Variscan foreland (Leeder \& Hardman, 1990) with more than 2,000 $\mathrm{m}$ of Westphalian sediment preserved in the basin depocentres. More than $200 \mathrm{~m}$ of Stephanian strata may also be preserved beneath the major erosional Late Permian unconformity.

The Pennsylvanian sequences in the basin record a progressive change from marine influenced fluvio-deltaic deposition (Chokierian to Marsdenian age), via poorly drained, fluvio-lacustrine lower- and then upper-delta plain deposition (Yeadonian to mid Bolsovian age), to well-drained, continental deposition (late Bolsovian to Stephanian age). Langsettian to early Bolsovian strata consist of grey, fluvio-lacustrine Coal Measures (Cowan, 1989; Collinson et al., 1993; Cole et al., 1995) with occasional marine horizons (e.g. McLean et al., 2004). Langsettian and early Duckmantian sequences are comparable to the sandstone-prone Pennine Coal Measures of the Durham Coalfield (Haszeldine \& Anderton, 1980; Fielding, 1984b), passing upwards (into mid Duckmantian to mid Bolsovian age) and laterally southwards (Cameron, 1993; Quirk, 1993) into finer-grained facies comparable to the mudstone-prone Pennine Coal Measures of the East Midlands, onshore UK (Rothwell \& Quinn, 1987; Fraser \& Gawthorpe, 1990). The mid Bolsovian is marked by a major intra-Westphalian unconformity, which appears to coincide with a period of nappe emplacement on the Variscan front (Hollmann, 1997; Hollmann \& von Wintereld, 1999) and a major shift in palaeoclimate (Besly et al., 1993). Above the unconformity lie mainly red (but occasionally grey - H. Kombrink, pers. comm., 2010) sandstone-prone continental beds of late Bolsovian to Stephanian age (Besly et al., 1993; Pearce et al., 2005).
Lublin-Volhynia (M. I. Waksmundzka \& B. Ptak, A. Kędzior, S. Opluštil)

The Lublin-Volhynia Coal Basin is entirely located on the East European Platform (Narkiewicz et al., 2007). It is about $350 \mathrm{~km}$ long and $80 \mathrm{~km}$ wide, elongated in a NW-SE direction, and lies between the Vistula and Bug rivers straddling the PolishUkrainian border. It has been interpreted as a pull-apart basin that developed under a transtensional regime (Narkiewicz et al., 1998) along the Trans-European Suture Zone, a major crustal discontinuity marking the western boundary of the EastEuropean Craton. The Carboniferous succession (Fig. 8), which is covered by post-Carboniferous sediments everywhere, varies from several tens of metres thick in the north-eastern part of the basin to c. $1,600 \mathrm{~m}$ thick in the central part. It lies unconformably on older sedimentary and in places crystalline basement, and varies from middle Viséan to Asturian in age, with coal-bearing beds first appearing in the upper Viséan Stage (Musiał \& Tabor, 1988; Waksmundzka, 2005).

The Terebin and lower Dęblin formations represent marineparalic deposits, with shallow shelf and deltaic conditions prevailing in the Polish part of basin (Waksmundzka \& Ptak, 2006). Marine-paralic conditions are indicated by the widespread occurrence of marine bands with faunas, alternating with terrestrial sediment deposited during short-term marine regressions. Restricted areas of peat accumulation developed during these regressive phases along the southern edge of the basin, notably between Chervonograd and Lviv on an eastward prolongation of the Bogdanka and Stoczek-Dorohucza synclines (Shulga et al., 2007; Zdanowski, 2007). The basin was connected both with the western and eastern European seas.

There is a stratigraphical gap between the upper and lower parts of the Dęblin Formation. Deposition continued under paralic conditions but with limited influence of the open sea. The zone of peat accumulation has been estimated as $100 \mathrm{~km}$ wide, restricted to coastal lowlands and deltas, and interdistributary areas of various scale (Shulga et al., 2007). The importance of fluvial environments increases upwards stratigraphically, with river systems transporting clastic material from eroded areas to the north and south-west of the basin. Marine incursions are represented by thin limestone interbeds, predominantly in the Ukrainian part of the basin. In contrast, coals in this formation are mainly found in the Polish part of the basin, suggesting conditions here were more continental. The uppermost part of the coal-bearing succession is not known from the Lviv-Volhynia segment due to post-Carboniferous erosion.

The Lublin and Magnuszew formations (Porzycki, 1979) are only known from the Polish part of the basin. The lower Lublin Formation represents deltaic and shallow shelf environments, but the upper part is composed only of continental deposits: fluvial siltstones, shales, Stigmaria seat-earth and sandstones. The coal seams, which vary in thickness from 0.10 to $2.77 \mathrm{~m}$, were accumulated within marshes on fluvial flood-plains. The 


\section{Lublin Coal Basin}

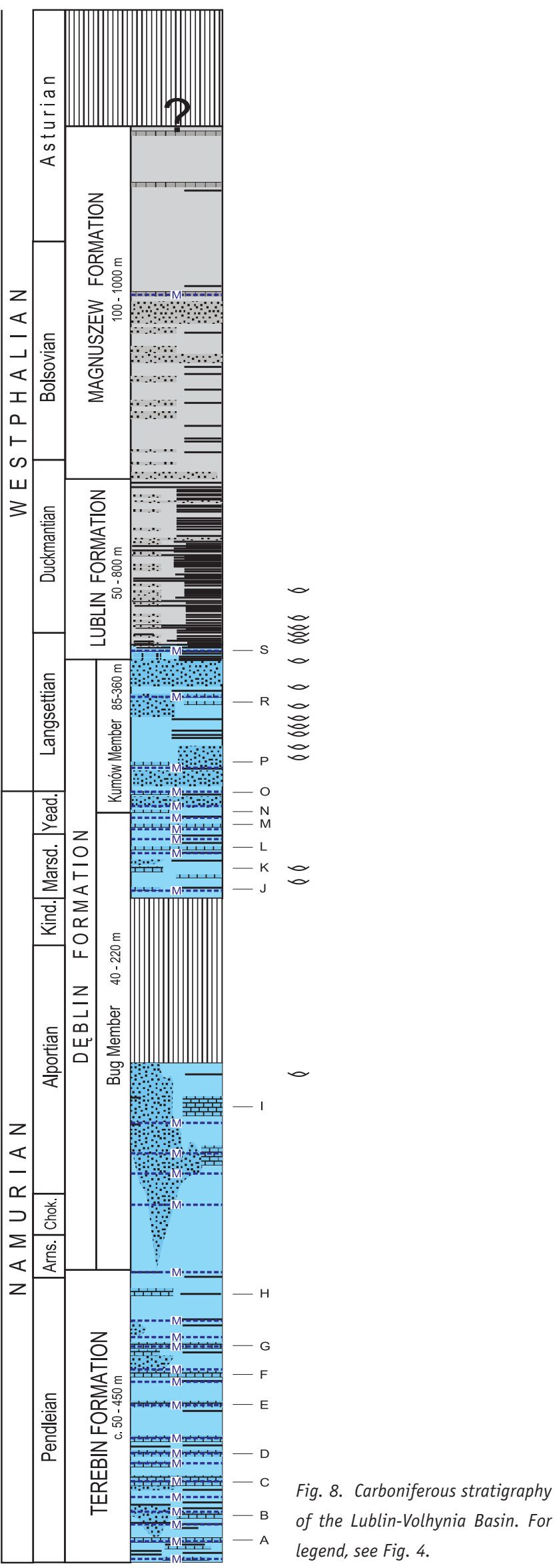

coal seams are composed mainly of clarino-vitrine lithotypes across most of the basin, but there are also lenses of fusaine and vitrite microlithotype in the northern part, whereas lenses of claystones and vitrite, clarite and duroclarite microlithotypes occur in the central part. The Magnuszew Formation consists of fluvial siltstones, sandstones and shales. Coal seams of mainly clarino-vitrine and vitrino-clarine lithotypes occur only in the lowermost part of this formation.

\section{Foreland basins}

Variscan foreland sedimentary basin developed along the margins of the active orogenic belt, between the Variscan Mountains and the external craton. The basin was a narrow c. 2,000 km long W-E striking area flanking the margin of the Variscan orogenic belt in Europe (Ziegler 1990; Gayer et al., 1993) and can be traced either in outcrop or subcrops from the southern British Isles, through northern France, south Belgium, the south-east Netherlands and adjacent part of Germany, to Poland and the north-east Czech Republic. The continuation of the basin belt further south-east is obscured by Alpine Carpathian Arc but as discussed later appears to extend to the Dobrudzha Basin on the western Black Sea coast (Tenchov, 1989).

These foreland basins differ from the cratonic basins to the north in having more strongly folded successions disrupted by both normal and reversed faults. They are sometimes separated from the cratonic parts of the basin complex by pre-Variscan highs: for instance, the coalfields of the southern British Isles, northern France and Belgium are separated from the Pennine Basin by the Wales-London-Brabant High. However, where there is no such high acting as a buffer, there is a transition in the Carboniferous deposits between foreland and cratonic settings (Kombrink et al., 2008).

The Variscan foreland was initiated by the closure of the Rheic 0cean, and the initial collision of Gondwana and Iberia/ Armorica during Late Palaeozoic times (marked by the Sudetian orogenic phase). The resulting Rheno-Hercynian nappes caused crustal thickening and served as the main source of clastics into the foreland basin (Warr, 2000; Franke, 2006). Deposition was controlled mainly by tectonics and sedimentary influx; purely eustatically-driven cyclothems as seen in the cratonic basins where there was slow and even thermal subsidence, are in the Variscan foreland basins overprinted by stronger tectonic influence and high clastic input (Heckel, 2002; Wagner \& Winkler-Prins, 2002). The basin-fill can be up to several kilometres thick along the southern margin, but the thickness-maxima for particular intervals indicate a northward migration of depocenters due to the progressive advance of the Rheno-Hercynian nappes in the same direction (Gayer et al., 1993). As with the cratonic basins, there was a progressive marine regression from east to west, with marine deposits finally disappearing in mid-Westphalian times. 
Volcanic rocks represent only a very small part of the basin fill because they were located outside of the main volcanic centres (Lyons et al., 1994). Volcanites are represented mostly by distal volcanic ash-falls resulting in thin tuff partings (tonsteins) either intercalated in coal seams or associated with clastic sediments. Although usually only a few millimetres to centimetres thick, they are often widespread and isochronous, and therefore represent excellent correlation markers and a source of radiometric ages (Lippolt et al., 1984; Burger, 1990; Burger \& Billig, 1987; Burger et al., 1997).

Deciding on the palaeogeographical position of the Dobrudzha Basin in north-eastern Bulgaria has presented certain problems. At least during Westphalian times, it was a fault-controlled basin and shows certain similarities with the intramontane basins within the Variscan Mountains. However, the macrofloras have closer affinities with those of the foreland basins, especially with Upper Silesia (e.g. Cleal, 2008d, 2008e). This seems to be supported by the location of the basin relative to the Variscan Front (Fig. 2; see also Tenchov, 1989). On the other hand, the basin-fill is relatively unfolded and thus resembles more the succession of the cratonic part of the foreland such as the Lublin-Volhynia Basin. In this report we have opted to regard it as one of the foreland basins located near the Variscan Front, but acknowledge that this decision must remain provisional.

\section{South Wales (S. Opluštil, C. J. Cleal \& A. Kędzior)}

This is the largest and stratigraphically most complete remnant of coal-bearing strata of the Variscan foreland (Fig. 9). It was historically the most extensively-worked coalfield in southern Britain and consequently the most studied (Kelling, 1988; Gayer \& Jones, 1989; Burgess \& Gayer, 2000). It has a current areal extent of c. $2,300 \mathrm{~km}^{2}$, although the basin was originally much wider, having been subjected to up to $60 \%$ tectonic shortening (Jones, 1991; Gayer et al., 1993). The lithostratigraphical nomenclature for the coalfield used here follows Woodland et al. (1957) and Waters et al. (2007, 2009).

Deposition in the basin occurred between Mississippian and earliest Stephanian times (Fig. 10). Viséan carbonates are unconformably overlain by clastic sediments of the Marros group (formerly the Millstone Grit), a change in deposition indicating the onset of flexural subsidence in a foreland basin (Gayer et al., 1993). The Marros Group spans a large part of the Namurian Stage and is essentially of marine origin with only a minor evidence of fluvial conditions (e.g. Jones, 1958) related to lowstands of glacio-eustatically-driven sea-level cycles, including the mid-Carboniferous eustatic event. It consists of sandstones, conglomerates and intercalated shales, with only thin coals. Sediment is deposited in coarsening upward cycles, the result of southerly prograding deltaic lobes of a lower delta plain (Hampson, 1998).

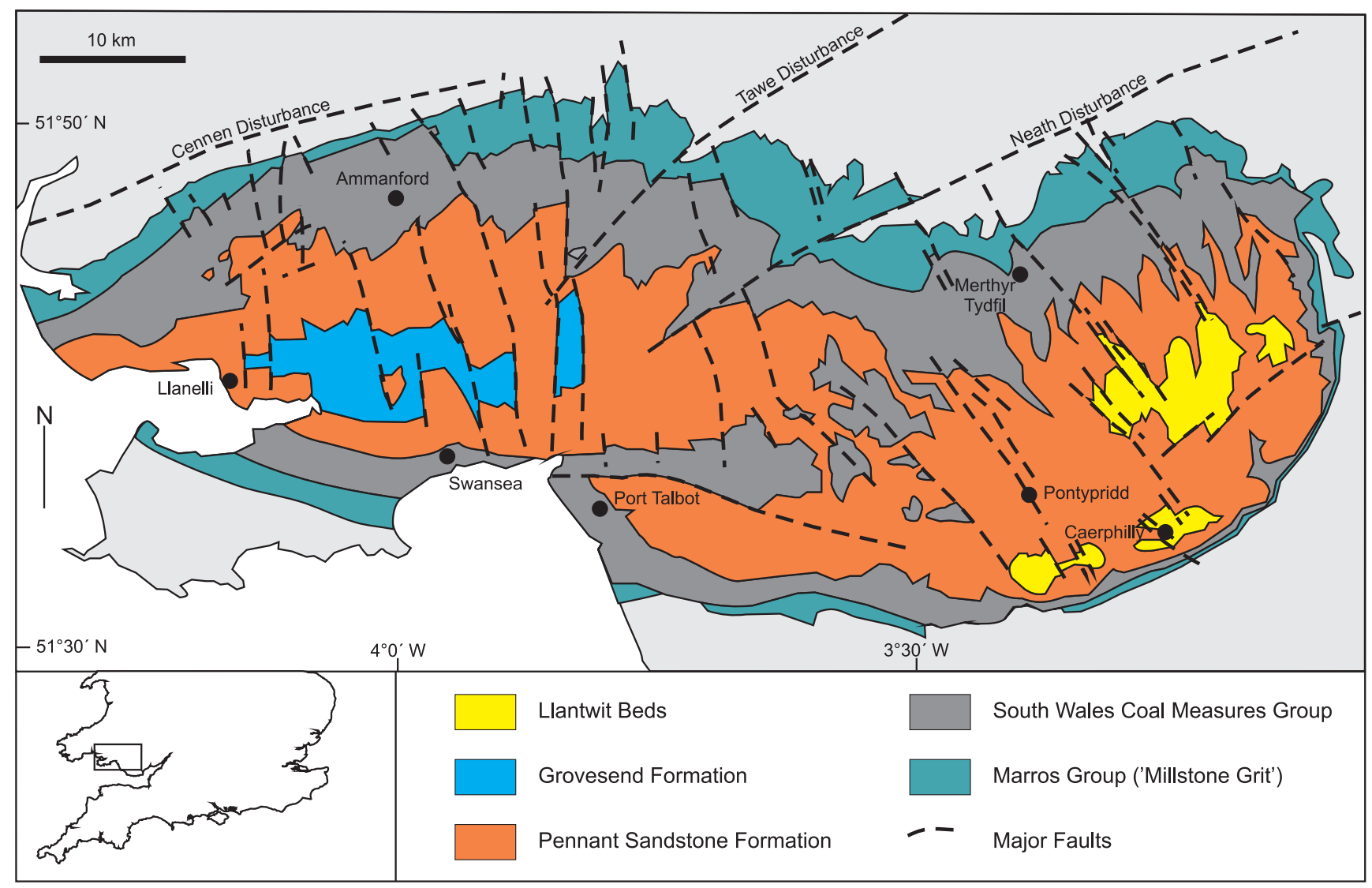

Fig. 9. South Wales Coalfield, UK. Redrawn from Cleal \& Thomas (1995). 


\section{South Wales}

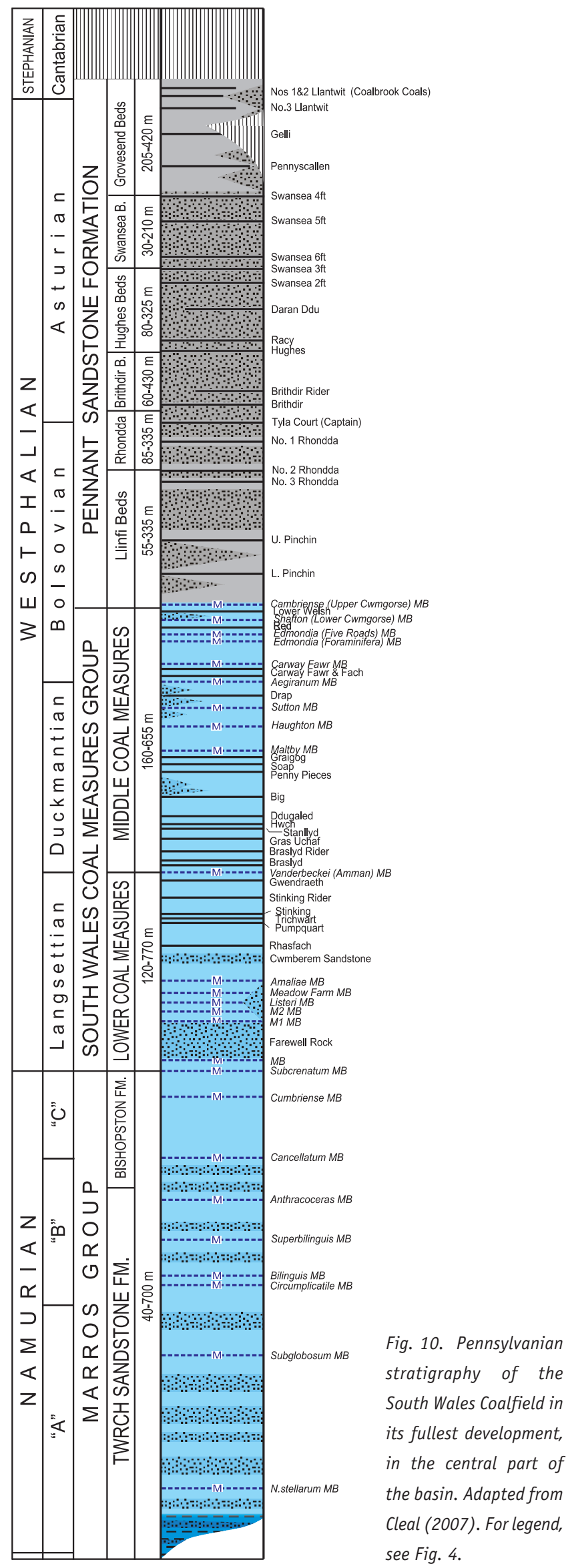

The Marros Group facies continues up to just above the Subcrenatum Marine Band, which marks the base of the Westphalian Stage. A thick sandstone body called the Farewell Rock immediately above the Subcrenatum Marine Band represents mostly fluvial channel fills or southward prograding delta-lobes although some thick lenticular coarse-grained and pebbly sandstone bodies in the south and east of the coalfield were formed in a litoral to sublitoral setting (Kelling \& Collinson, 1992). This is then replaced by the South Wales Coal Measures Group, formed when fluvial conditions became more dominant and which persisted until the end of deposition in early Stephanian times (Jones, 1989, 1991; Hartley \& Warr, 1990; Hartley, 1993a, 1993b). Marine influence is restricted to numerous but discrete marine bands. All the significant changes in thickness and sedimentary environment in the group have been related to synsedimentary tectonic activity associated with the northward migration of the Variscan Orogen (Kelling, 1974, 1988; Gayer and Jones, 1989; Hartley, 1993a, 1993b).

The lower Lower Coal Measures Formation consists mainly of fine-grained lithologies with thin and impersistent coals, common Lingula-bearing marine bands and scattered sandstone channel fills. This has been interpreted as deposits in a lower delta plain or coastal plain environment (Kelling, 1974; Jones, 1989). The remaining part of the Lower Coal Measures and the Middle Coal Measures formations have thicker coal seams, seat earths, sideritic ironstones and relatively few marine bands. Clastics were derived mostly from northerly and easterly located sources (Wales-London-Brabant High and Usk Axis, respectively) and only to a lesser extent from the south (Jones, 1989; Hartley, 1993b). The presence of thick coals and less frequent marine incursions are indicative of an upper delta plain environment in this part of the succession (Kelling, 1974; Jones, 1989).

The junction between the South Wales Coal Measures and the overlying Pennant Sandstone Formation is diachronous across the basin (Woodland et al., 1957). In the central part of the basin, where the Pennant Sandstone Formation reaches its maximum thickness of $1,700 \mathrm{~m}$, the junction with the underlying formation is just above the Cambriense Marine Band (sometimes known locally as the Upper Cwm Gorse Marine Band). In the eastern part of the basin, however, the base of the formation is at a significantly higher stratigraphical level; here, the interval between the Cambriense Marine Band and the base of the Pennant Sandstone is called the Upper Coal Measures Formation. There is also a stratigraphical gap in the Pennant Sandstone in the eastern part of the basin, possibly coinciding with Leonian tectonic movement (Cleal, 1978).

The Pennant Sandstone is dominated by coarse-grained, locally conglomeratic, feldspatic and micaceous lithic arenites. Palaeocurrent data and the northwards thinning of the formation suggest the main clastic input of the poorly matured sediments was from a rising Variscan hinterland to the south (Kelling, 1974, 1988; Jones, 1989; Gayer and Jones, 1989). There is generally a slight increase in grain size in the upper 
part of the formation, indicating a northward progradation of the alluvial system. The erosive-based coarse fluvial lithic sandstone bodies comprise about $70 \%$ of the formation and, although there are several thick and important seams, in general coal development is significantly poorer compared to the underlying Coal Measures Group. The sandstones have a predominance of in-channel bedforms and their low palaeocurrent dispersion, as well as the low proportion of floodplain fines and the absence of point bar deposits indicate they were formed in low to moderate sinuosity braided rivers (Kelling \& Collinson, 1992). Thick and amalgamated sandstones are interpreted by Jones (1989) as channel bars. The presence of rounded coal clasts in this unit suggests that this southerly located source area contained already compacted coal-bearing sediments that became cannibalised as the Variscan deformation propagated northward (Gayer et al., 1993, Gayer \& Pešek, 1992).

The youngest unit in the central part of the coalfield, the Grovesend Formation, is marked by a change from a sandstoneto a mudstone-dominated succession with thin, only locally mineable coals and subordinate sandstones in its upper part. This indicates predominantly floodplain deposition in a meandering and/or anastomosing fluvial system. The occasional presence of red-beds may indicate periods of reduced subsidence resulting in water table lowering (Besly, 1988). In the eastern part of the coalfield, strata of similar age are about $150 \mathrm{~m}$ of Pennant-like sandstones (locally known as the Llantwit Beds) that lie with clear discordance on top of the Pennant Sandstone Formation proper. These Llantwit beds indicate that a braided fluvial system was operating in this part of the basin. Cleal $(1991 a, 1997)$ considered that the Llantwit Beds were a lateral equivalent of the Pennant Sandstone Formation of the Forest of Dean, rather than being genetically related to the South Wales Pennant Sandstone which is stratigraphically older and probably of different provenance.

\section{Forest of Dean (S. Opluštil, C. J. Cleal \& A. Kędzior)}

This small coalfield, about $100 \mathrm{~km}^{2}$ in size, represents an erosional and tectonic remnant of the northern margin of the foreland basin belt in southern Britain (Fig. 11); there are also smaller outcrops known as the Severn and Newent coalfields; Cleal, 1986, 1987). The Pennsylvanian strata of this relict lie unconformably on mainly Mississippian and Devonian sediments. Due to its marginal position within the Variscan foreland Basin and its proximity to the southern slope of the Wales-London-Brabant High, Pennsylvanian deposition in the basin did not start until late Asturian times and lasted until early Cantabrian times (Fig. 12).

The lower part of the succession consists of mainly alluvial sandstones with subsidiary coals and mudstones (Stead, 1974) that are of similar facies to the Pennant Sandstone Formation of South Wales, although they are a little younger and probably of different provenance. The basal part of this interval consists

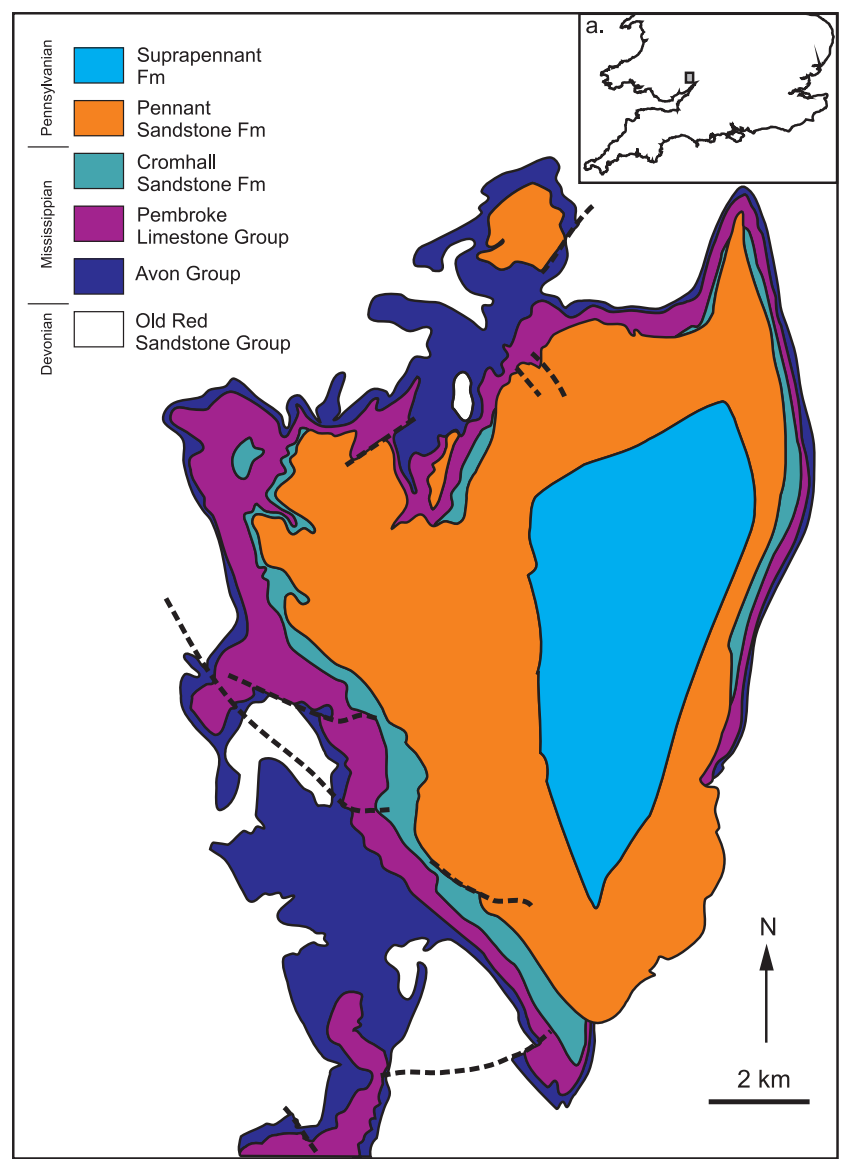

Fig. 11. Carboniferous of the Forest of Dean. Redrawn from Trotter (1942) and Gayer \& Stead (1971).

of an interval of quartzose conglomerates and pinkish grey quartzose coarse-grained sandstones, whose thickness and clast size increases northwards (Jones, 1972). Traditionally these lower beds, which only have very thin coals, have been referred to as the Trenchard Formation but Cleal \& Thomas (1995) have argued that they are better regarded as a member of the Pennant Sandstone Formation.

These alluvial deposits are overlain by more argillaceous sediment called the Suprapennant Formation. The lower part of this formation (the Household Coal Member) is the most important coal-bearing unit in the coalfield; the Woorgreen Member is similar but contains fewer coals. The intervening Serridge Sandstone is a mostly coal-barren, red-bed interval. Based on the macrofloras, the Westphalian-Stephanian stage boundary has been placed in the upper part of the Household Coal Member (Wagner \& Spinner, 1972).

Some distance to the east, coal-bearing strata are concealed below thick Mesozoic deposits in 0xfordshire and Berkshire, and show a similar succession to the Forest of Dean (Worssam, 1963; Poole, 1969; Dunham, \& Poole, 1974; Foster et al., 1989). The main difference is that palynological evidence suggests that in Berkshire there is a condensed sequence of early Westphalian age coal-bearing rocks below the Pennant Sandstone Formation, not seen in the Forest of Dean. 


\section{Forest of Dean}

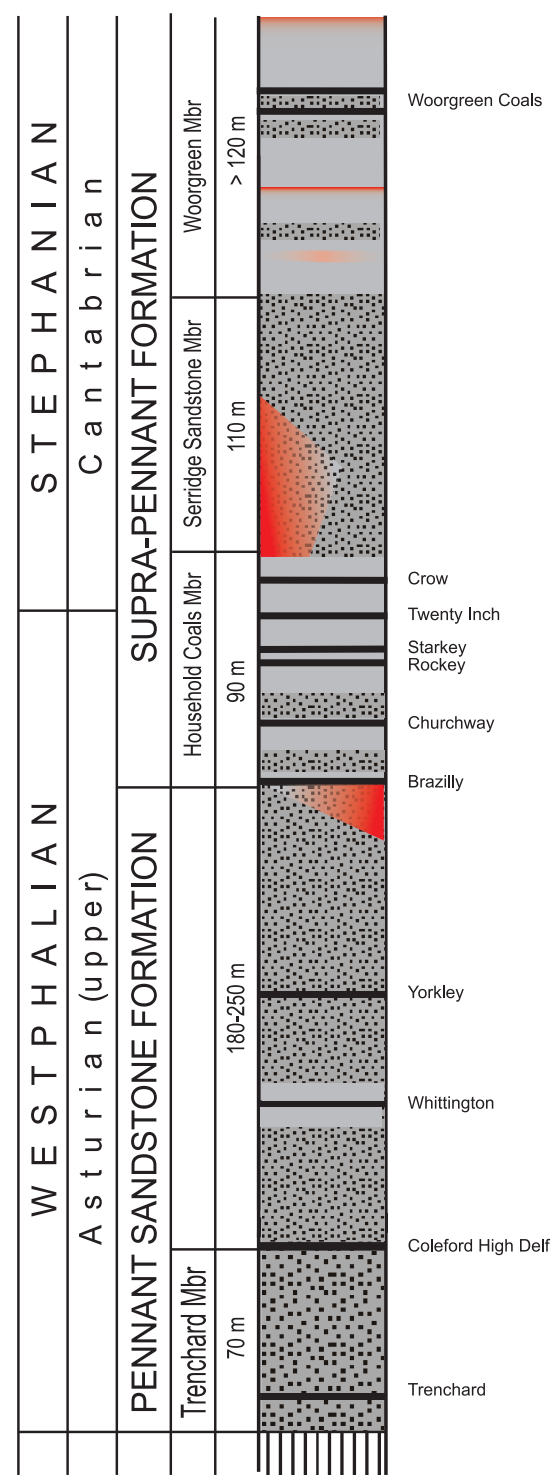

Fig. 12. Pennsylvanian stratigraphy of the Forest of Dean Coalfield, UK. Adapted from Trotter (1942). For legend, see Fig. 4.

\section{Bristol-Somerset (S. Opluštil \& A. Kędzior)}

This large coalfield covers about $870 \mathrm{~km}^{2}$, of which about $700 \mathrm{~km}^{2}$ is concealed below Mesozoic cover. Due to the limited exposure and the lack of recent mining activity in the area, the geology of this coalfield is relatively poorly understood. The most detailed account, including significant historical records, is by Kellaway \& Welch (1993).

The lithological development is essentially similar to that of the South Wales Coalfield, and a similar set of lithostratigraphical units is used: Mississippian limestones are overlain by middle to late Namurian Marros Group - a lower delta plain complex with frequent marine bands. This is in turn overlain by a Langsettian to early Bolsovian coal-bearing sequence containing up to 40 mineable coal seams usually less than $1 \mathrm{~m}$ thick, and assigned to the South Wales Coal Measures Group. The equivalent of the South Wales Pennant Sandstone Formation is assigned here to the Downed and Mangotsfield formations, 90$610 \mathrm{~m}$ and $420 \mathrm{~m}$ thick, respectively (Kellaway, 1969; Stead, 1974; Kellaway and Welch, 1993). This complex is thinning northward towards the Forest of Dean Coalfield.

Biostratigraphical data from the Downed and Mangotsfield formations is limited, but there is some evidence to suggest that there is a stratigraphical gap above these Pennant-like formations, corresponding to the similar depositional break in the eastern part of the South Wales Coalfield. The equivalent of the Grovesend Formation in the Bristol-Somerset Coalfield is lithologically similar but up to $900 \mathrm{~m}$ thick, and consists of a complex of continental grey coal-bearing and red coal-barren sediments, divided into the Farrington, Barren Red, Radstock and Publow formations. Mudstone-dominated sediments with localised channel fill sandstones bodies indicate deposition in a meandering fluvial system. The Farrington and Radstock formations contain the major coal seams of the coalfield. The Westphalian-Stephanian boundary was located by Cleal (1997) in the lower part of the youngest Publow Formation with only few workable coal seams, but more recently Cleal et al. (2003) suggested it may be at a lower level, somewhere between the Radstock and Farrington formations.

\section{Limburg (T.B. van Hoof, O.A. Abbink \& I.M. van Waveren)}

The historical Dutch coal mining area is restricted to the Province of Limburg, in the southernmost part of the Netherlands. This area belongs to the most south-eastern part of the Campine Basin (Fig. 13). The Campine Basin was an elongated depocentre situated between the Wales-London-Brabant High and the Krefeld High - Maasbommel High complex (Fig. 13), and was a more or less continuous subsiding basin during LangsettianDuckmantian times. Pulses of uplift occurred during BolsovianStephanian times, and are associated with an increase of sandstones. This resulted in north-south trending depocentres such as the Ems Basin (Selter, 1990) of which a small part is located in the most eastern part of the Netherlands (Fig. 13). Post-Westphalian tectonics led to uplift phases in most areas, which resulted in an unconformity between the top Carboniferous and overlying deposits. Nowadays in the Limburg area, Duckmantian and Bolsovian deposits subcrop beneath Jurassic and Tertiary deposits. In most other parts of the Netherlands, Carboniferous strata subcrop beneath the Upper Rotliegend Group.

In the Campine basin, late Langsettian to early Bolsovian sediments mostly belong to the Maurits Formation, which is characterized by mainly light-grey mudstones with relatively frequent coal-seams intercalated with sandstones; this formation correlates with the Productive Coal Measures in Britain. The depositional environment was predominantly lacustrine with intermittent swamp and fluvial-plain conditions. Isolated sandstone beds were formed by meandering and anastomosing 


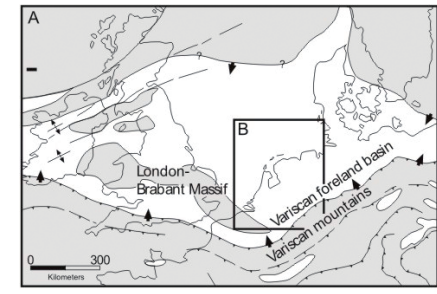

a.

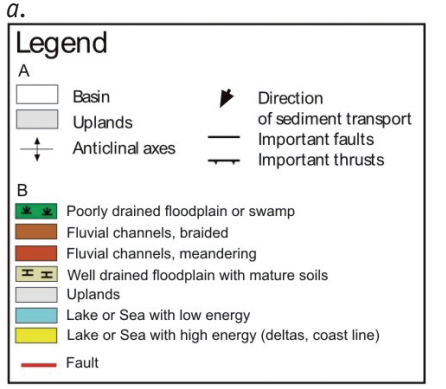

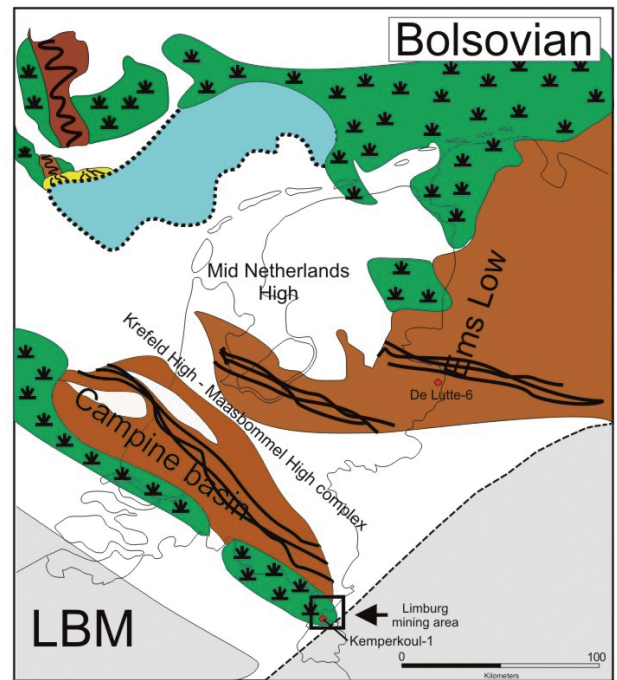

b.

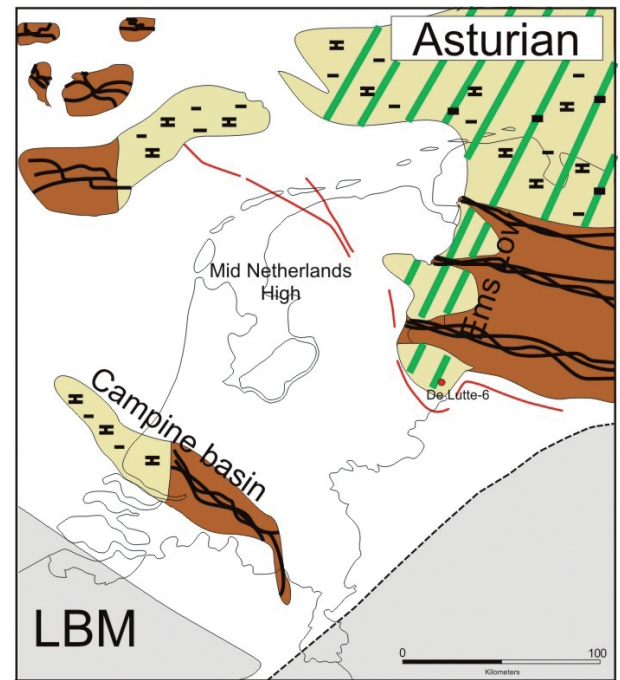

c.

Fig. 13. Palaeoenvironments of the Limburg Coalfield during Middle Pennsylvanian times (after van Buggenum \& den Hartog Jager, 2007). LBM = LondonBrabant Massif. a. General palaeogeographical position of the Netherlands in Middle Pennsylvanian times; b. Bolsovian reconstruction; c. Asturian reconstruction.

fluvial systems, which also formed lacustrine deltas and crevasses (David, 1990). In general, marine incursions were rare and only in the Limburg mining area (south-eastern part of the Campine Basin) have marine bands been recognized sufficiently well to be used for stratigraphical correlation.

Late Bolsovian deposits in the south-eastern part of the Campine Basin change to alternating lake, swamp and floodplain deposits, with sandstones reflecting fluvial channel fills, and are known as the Kemperkoul Member (Van Adrichem Boogaert \& Kouwe, 1993). In the more western and central parts of the Campine Basin, the upper Bolsovian Substage is dominated by massive fluvial sandstones of the Hellevoetsluis Formation (Van Adrichem Boogaert \& Kouwe, 1993). Similar fluvial sandstones in the Dutch part of the Ems Low Basin, but which range up into the lower Asturian Substage, are known as the Tubbergen Formations (Van Adrichem Boogaert \& Kouwe, 1993). These massive fluvial sandstones are regarded as a lateral equivalent of the Hospital Ground Formation in the southern North Sea.

In the western and central part of the Campine Basin, the Hellevoetsluis Formation is succeeded by well-drained distal fluvial or floodplain deposits of the Strijen Formation, which are late Bolsovian to Asturian in age (Van Adrichem Boogaert \& Kouwe, 1993). In the Ems Low area, the Tubbergen Formation is succeeded by deposits of the De Lutte Formation represented by a well-drained distal flood-plain setting, where sands were mainly deposited by sheet floods or minor fluvial-fan systems (Van Adrichem Boogaert \& Kouwe, 1993). This formation consists of a succession of reddish brown to grey-green, silty to very fine-grained sandy mudstones intercalated with light grey, white and pink fine to medium grained sandstones, and are informally referred to as the Barren Measures as coal seams are thin and rare (Van der Meer \& Pagnier, 1996). A discrepancy that existed between the palynological and palaeobotanical age-interpretation of this well (Van Amerom, 1996; Van de Laar \& Van der Zwan, 1996) has been resolved and it now seems that the bulk of the formation is early Stephanian in age (Van Hoof et al., 2007; Van Waveren et al., 2008). The soil types found are seat earths or gleys, ferralic soils, immature calcic soils and mature calcic soils (Van der Meer \& Pagnier, 1996; Van der Zwan et al., 1993). There is a transition in soil type preserved in the De Lutte Formation suggesting a slow and gradual change from tropical-wet to arid and semi-arid conditions across the Asturian-Cantabrian boundary, indicating a change in regional climate (Van der Zwan et al., 1993). The De Lutte and Strijen formations can be considered lateral equivalents of the Step Graben Formation in the Dutch North Sea sector.

\section{Ruhr and nearby basins (A. Kędzior, D. Uhl \& S. Opluštil)}

The Pennsylvanian geology, sedimentology and stratigraphy of the Ruhr and nearby basins (i.e. Aachen Coalfields, Osnabrück area) have recently been summarized in a monograph on the Pennsylvanian in Germany published by the German Stratigraphic Commission (e.g. Burger et al., 2005; Drozdzewski, 2005; Eagar, 2005; Hartkopf-Fröder, 2005; Josten, 2005; Köwing \& Rabitz, 2005; Menning et al., 2005; Süss, 2005; Wrede \& Ribbert, 2005; Wrede \& Zeller, 2005).

The basins considered here developed north of the Variscan Orogen and represent foreland-molasse basins. The basin is bounded by the Lippstadt Highland to the northeast and the Krefeld High to the southwest. The southeastern boundary is erosional but it is supposed that the basin was prolongated to the Remscheid or Ebbe anticlines. On the northern flank, the basin is covered by about 2,000 m of mostly Late Cretaceous deposits. The elongate basin has a SW-NE alignment, and is 
$150 \mathrm{~km}$ long and about $80 \mathrm{~km}$ wide (Drozdzewski, 1993, fig. 1). The total thickness of the coal-bearing sequence attains 5,000 $\mathrm{m}$ in the south-eastern part of the basin (close to the Variscan Orogen front) and towards the northwest decreases to 4,000 m.

Although some thin coal-seams are known from older units (e.g. the Kaisberg Formation of Namurian B age contains three coals) coal-bearing strata in the Ruhr are usually accepted as starting with the Yeadonian Substage. The coal-bearing sequence is divided into formations essentially following Wrede \& Ribbert (2005) (Fig. 14). Details of the coal composition in each formation is summarised in Table 2. The Sprockhovel and Witten formations are paralic deposits with frequent largescale marine incursions (Hampson et al., 1999, fig. 3; Suess et al., 2007). They include thick and wide-spread sandstone bodies, and thin discontinuous coals with a high ash and sulphur content. This interval is overlain by predominantly fine-grained, coal-bearing deposits formed in shallow delta platforms and delta plains, and referred to the Bochum and Essen formations (Suess et al., 2007). The Bochum Formation has several marine bands, but the Essen Formation mostly only has brackish fauna horizons. The distribution of sandstone bodies varies across the basin (Casshyap, 1975) and in the Essen Formation these sandstones often have an erosional base (Diessel, 1992, fig. 7.35). Sediment transport tended to be parallel to the Variscan orogenic front.

In middle Duckmantian times there was a change to more middle and upper delta plain conditions (Suess et al., 2007) and the resulting Horst and Dorsten formation have much fewer brackish and marine fauna horizons (Strehlau, 1990; Drozdzewski, 2005); the boundary between the two formations is at the stratigraphically-highest (Ägir) marine band in the basin. The total content of coals and seat-earths is also less. Although fine-grained sediment remain dominant (Strehlau, 1990; Wrede \& Ribbert, 2005), there are more sandstone bodies with erosional bases and internal surfaces indicating repeated episodes of deposition and erosion (Diessel, 1992). This trend to increasingly upper delta plain and alluvial conditions is continued into the Lembeck Formation, which is dominated by thick sandstone bodies and conglomerates (Diessel, 1992), although there are also ten coal seams and numerous seat earths (Wrede \& Ribbert, 2005).

There are no Asturian deposits in the Ruhr Basin itself, but they occur in the Lower Saxony Basin near Osnabrück to the north. The lower part of this formation is dominated by grey clastics with 10 coal seam-groups, but the upper part is dominated by red clastics with no coals (Köwing \& Rabitz, 2005). At Piesberg near 0snabrück and in some borehole cores, the presence of a thin marine band has been demonstrated by means of geophysical (Schuster, 1968, 1971) and micropalaeontological analyses (Knauff et al., 1971).

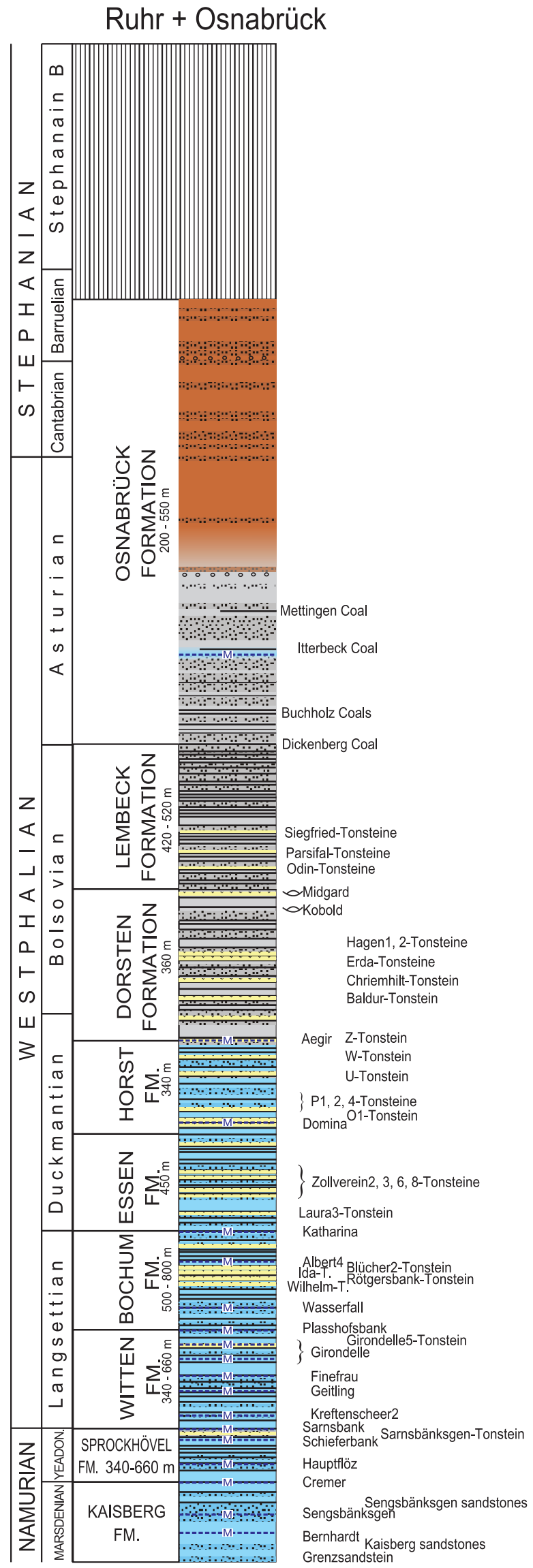

Fig. 14. Pennsylvanian stratigraphy of the Ruhr Coalfield, Germany. For legend, see Fig. 4. 
Table 2. Changing coal compositon through the Pennsylvanian Subsystem of the Ruhr Coalfield (data based on Strehlau, 1990 and Wrede \& Ribbert, 2005).

\begin{tabular}{llllllll}
\hline Formation & No. of seams and proportion & Sulphur & Mineral & \multicolumn{2}{l}{ Vitrinite } & \multicolumn{3}{l}{ Maceral groups (\%) } \\
\cline { 6 - 8 } & of formation thickness & Content (\%) & matter (\%) & reflectance $\left(\mathbf{R}_{\mathbf{r}}\right)$ & Vitrinite & Liptinite & Inertinite \\
\hline Lembeck & $10(3-4 \%)$ & 1.85 & 7 & & 64 & 18 & 12 \\
Dorsten & $13(4 \%)$ & 1.38 & 5 & & 65 & 17 & 14 \\
Horst & c. $15(4-6 \%)$ & 1.20 & 4 & 0.89 & 66 & 14 & 15 \\
Essen & c. $28(3-5.5 \%)$ & 1.06 & 4 & & 64 & 13 & 19 \\
Bochum & c. $50(2.5-6 \%)$ & 1.10 & 5 & 1.38 & 70 & 23 & 4 \\
Witten & $19(1.1 \%)$ & 1.41 & 5 & 1.80 & 77 & c. 10 & c. 10 \\
Sprockhovel & $19(0.8 \%)$ & 2.37 & 10 & 2.15 & - & - & - \\
\hline
\end{tabular}

Upper Silesia (A. Kędzior \& S. Opluštil)

This triangular shaped coalfield is the largest coal basin in Europe with a total area of c. 7,400 km² (Fig. 15). It has mainly tectonic boundaries: on its western side overthrusted Devonian to Mississippian sediments of the Moravo-Silesian fold-zone; and to the north the Lubliniec-Kraków tectonic zone, a part of a larger tectonic structure known as the Hamburg-KrakówDobrodzha Fault. Based on records in deep boreholes, its southern limits have been identified below Miocene deposits and nappes of the Outer Carpathians.
Some typical features of flexural foreland basins have been observed (Gradziński, 1982): (1) a general decrease in the rate of subsidence and a gradual eastwards shift of the zone of maximum subsidence (the opposite direction to the overthrusted Moravo-Silesian sediments); (2) a general transport direction parallel to the front of the orogen; (3) stronger tectonic deformation adjacent to the orogen; and (4) cannibalism of parts of the previously deposited sediments. The Upper Silesian Coal Basin, therefore, appears to have been an integral part of the Variscan foreland paralic basin-complex. Unlike the other coal basins in this complex to the west, however, there is

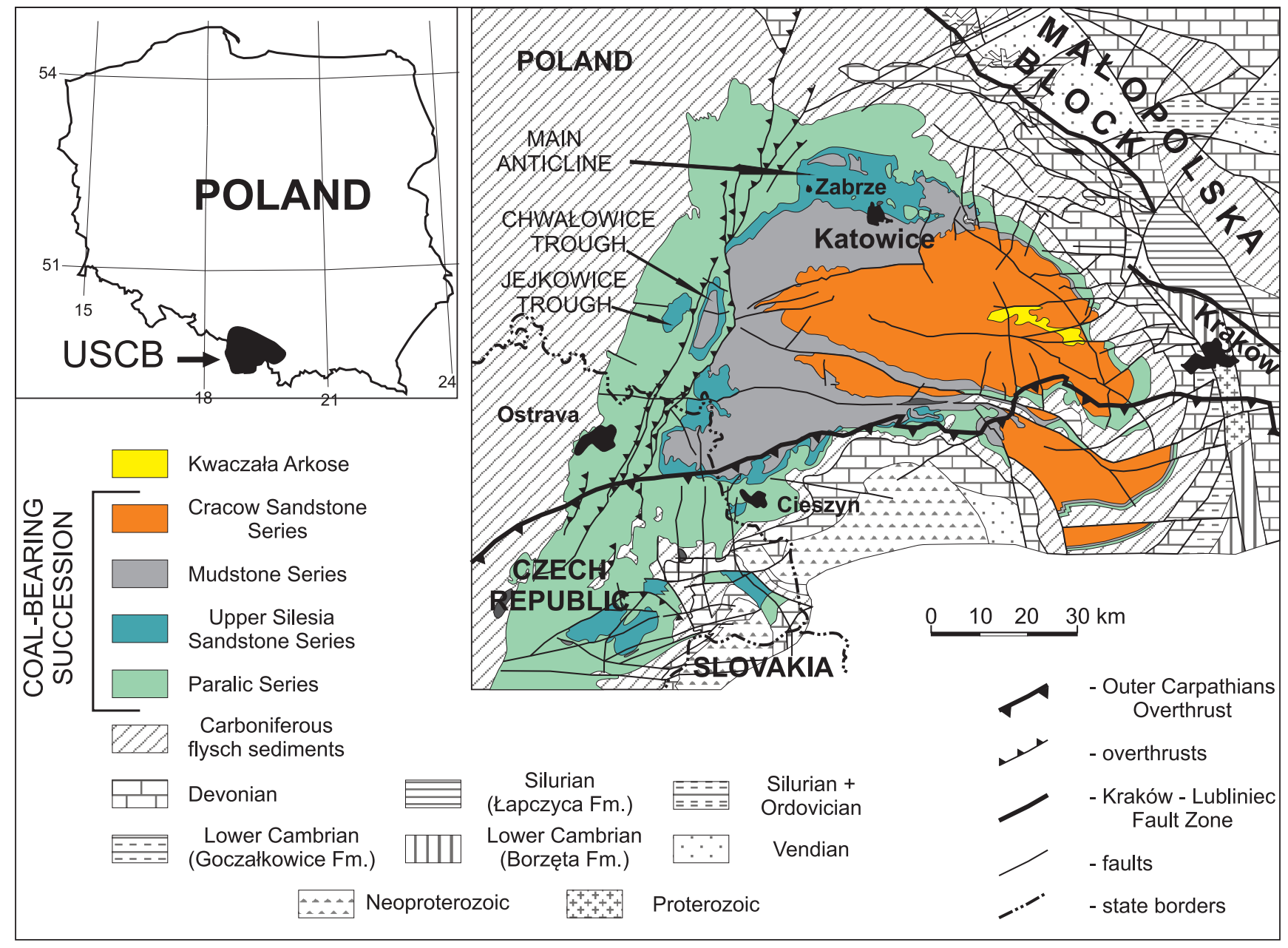

Fig. 15. Geological map of the Upper Silesia Coal Basin (after Buta \& Żaba, 2005). 
no evidence of marine deposits in the Pennsylvanian part of the succession.

There are up to 8,500 $\mathrm{m}$ of coal-bearing deposits, ranging in age from late Mississippian to Asturian (Fig. 16). They are characterized by repeating lithosomes of sandstone, mudstone and coal seams, and with a virtual lack of limestones. The succession consists of two parts (Dembowski, 1972): the Mississippian 'Paralic Series' with evidence of repeated eustatic marine transgressions (Doktor \& Gradziński, 2000); and the Pennsylvanian continental 'Limnic Series' with no marine intervals.

The 'Paralic Series' is most fully developed in the western, Czech part of the basin, where four subdivisions are recognised (as shown in Fig. 16). In the eastern part of the basin, the succession is more condensed and only three divisions are recognised (Kotas \& Malczyk, 1972). The 'Limnic Series' is, in contrast, most fully developed in the western and to an extent the central part of the basin, and is all but absent from the Czech part. This upper part of the succession is divided into three major divisions and seven subdivisions (Fig. 16). This distinct tripartite division was caused mainly by allogenic factors. The development of intervals dominated by coarsegrained deposits (the Upper Silesia Sandstone and Cracow Sandstone series) was the result of an increasing supply of clastic material due to tectonic movement in the source areas. Significant lateral and vertical variability on both regional and local scales of the clastic and phytogenic sediments was controlled mainly by autogenic phenomena (Doktor \& Gradziński, 2000).

The coal-bearing succession is overlain by the Kwaczała Arkose, which lacks coal seams (Siedlecki, 1951). Several stratigraphical gaps have been recognized within that part of the basin fill (Kędzior et al., 2007).

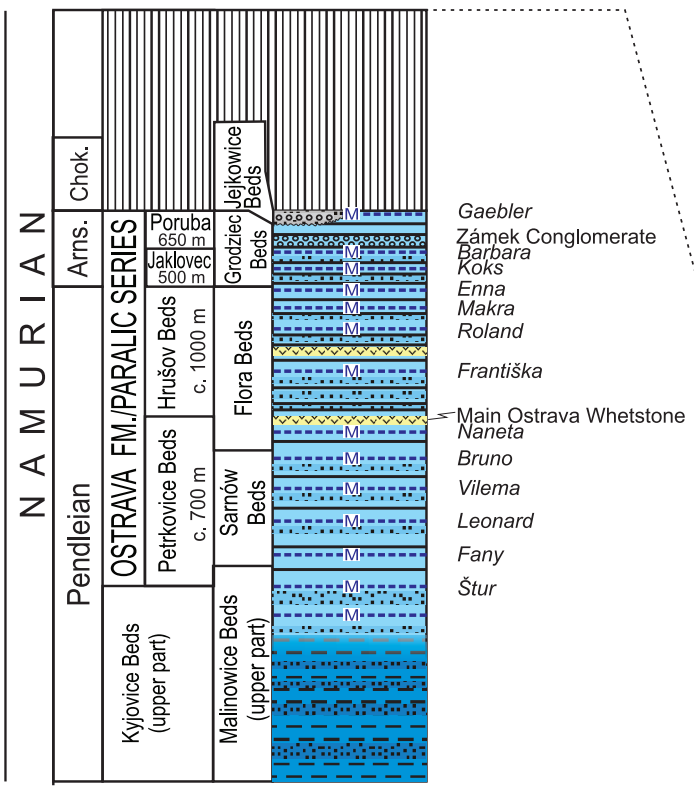

Upper Silesia Coal Basin

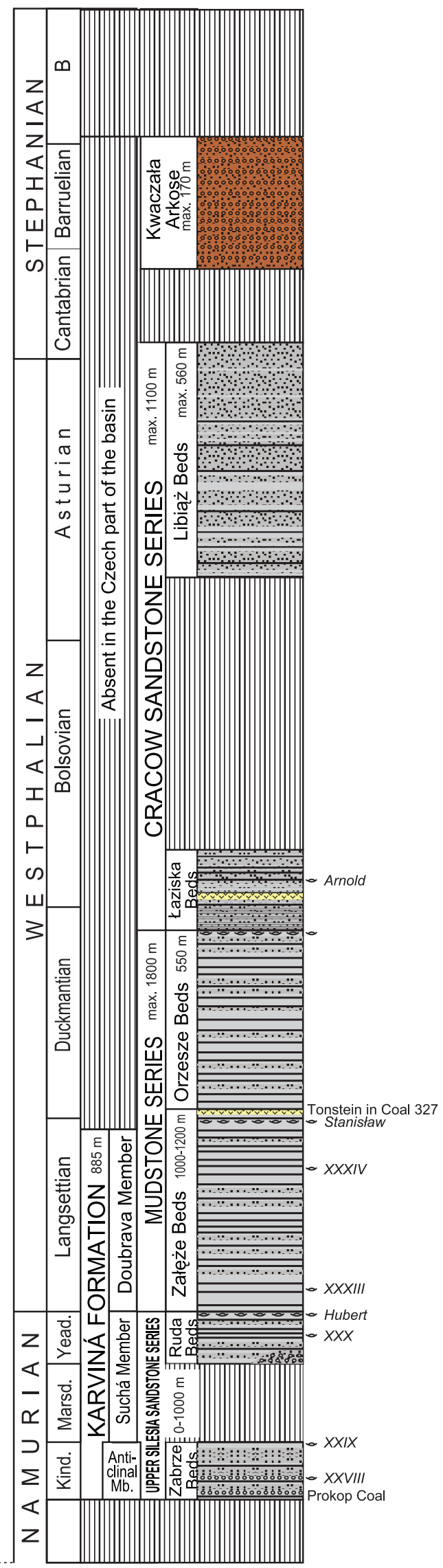

Fig. 16. Pennsylvanian stratigraphy of the Upper Silesia Coal Basin. For legend, see Fig. 4. 


\section{Dobrudzha (Y. Tenchov \& A. Kędzior)}

The Dobrudzha Basin (Fig. 17) was formed in the Saxo-Thuringian Zone, in a depression bounded by the Shabla and Seltse faults (Fig. 18). To the north of the Shabla Fault (A in Fig. 18), mainly marine sedimentation was continuous from Devonian to at least early Westphalian times. To the south of the Seltse Fault, an extensive plain developed in Viséan and early Namurian times, at least $60 \mathrm{~km}$ wide (as far as the Marash Borehole) and slightly inclined to the north ( $C$ in Fig. 18), where localised ephemeral swamps produced thin and intermittently developed coals.
The Dobrudzha Basin, which was $500 \mathrm{~km}^{2}$ in size, was one of a series of similar depressions along the large faults around the Donets Basin: other examples include Lviv-Volhynia, maybe Reşiţa (Romania), the Black Sea coastal coalfields in Turkey, and perhaps the coalfield of the Northern Caucasus slope. Marine Viséan-Namurian deposits lie unconformably on Devonian limestones, and then pass up into continental coal-bearing deposits. Activation of the Seltse Fault caused intensive erosion and considerable quantities of sediment to be washed into the basin from the southern side of the fault, resulting in deposition of the Irechek Member. The coal pebbles and fragment of dried

Fig. 17. Variscan zones and Carboniferous deposits in Bulgaria.
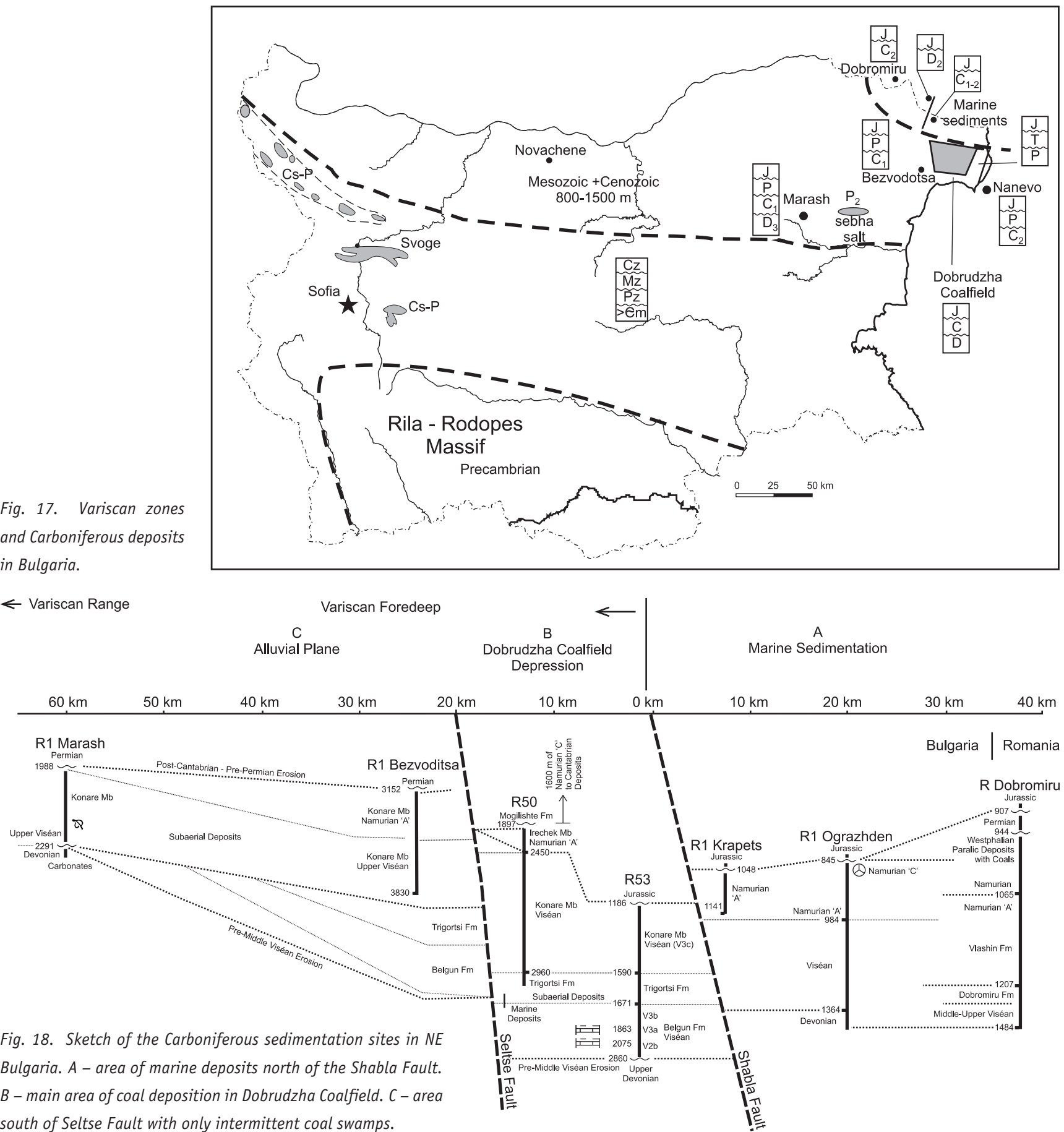
trunk fragments are characteristic for the main part of this member. The top of the member has some coal-bearing deposits dated as Namurian A in age. The sandstones are without pebbles.

A short break in sedimentation followed, maybe reflecting the Erzgebirge tectonic phase, although the exact length of the hiatus is still under discussion (Tenchov, 2004a; 2005). Alluvial, swamp and lacustrine conditions developed in the Dobrudzha
Basin, resulting in 1,600 m of Namurian $C$ to Cantabrian coalbearing deposits - the Balchik Group, which is divided into seven formations (Fig. 19).

The Mogilishte Formation is mostly characterised by finegrained clastic deposits with coals indicating mainly lacustrine conditions in the middle part of the basin and swamps in more marginal positions (Tenchov, 2005). There are also sandstone

\section{Dobrudzha}
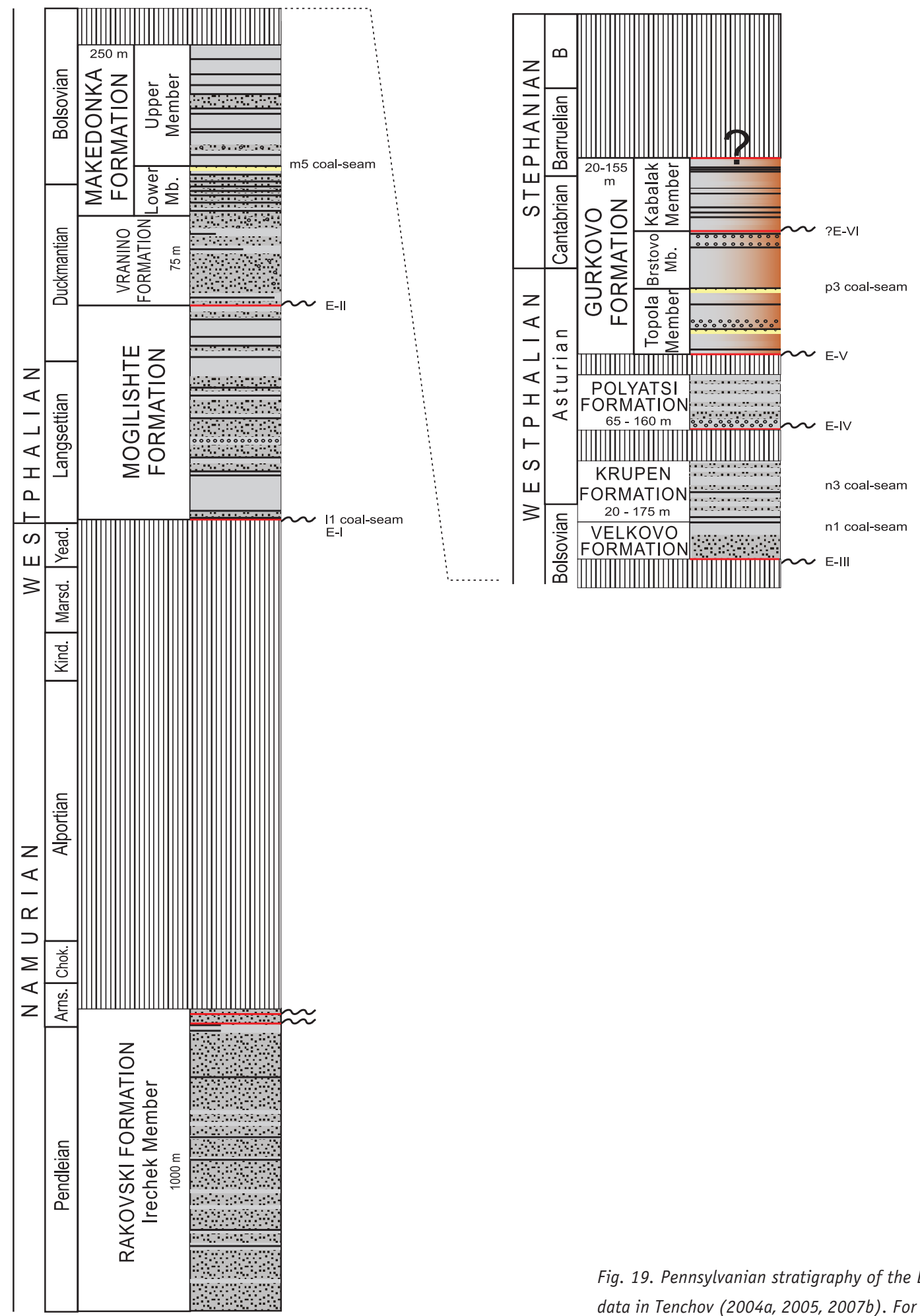

Fig. 19. Pennsylvanian stratigraphy of the Dobrudzha Coalfield. Based on data in Tenchov (2004a, 2005, 2007b). For legend, see Fig. 4. 
bodies, notably in the middle part of the formation where there are also fewer coals, and this interval is interpreted as braided river deposits on an alluvial plain in the southern part of the basin. Thin conglomerate layers in this middle part of the formation contain coal pebbles, and claystone clasts resulting from the erosion of soft, only partly lithified sediment.

The remainder of the Balchik Group consists of three units: each has an erosional non-sequence at the base, a lower mainly coal-barren formation and an overlying coal-bearing formation (Tenchov, 2007b). The lower, coal-barren formation of each couplet consists mainly of coarse-grained sandstones and conglomerates deposited in braided-river systems and alluvial fans, and often include coal clasts eroded from underlying formations. There are also clasts of volcanic rocks and glass probably derived from outside of the basin. In one of these intervals (the Bolsovian Velkovo Formation) some sandstones have anhydritic cement suggesting deposition in a dry climate.

The upper formation of each couplet often does not differ substantially from the underlying unit except for the presence of coal seams, and for the Vranino/Makedonka and Velkovo/ Krupen couplets the boundary is transitional (Tenchov, 2007b). There tend to be more mudstones and shales than in the lower formations, but coarse, often volcanomictic sandstones still predoiminate, especially in the lower parts of the formations. Deposition was in meandering, high sinuosity or braided rivers, often draining into a lake in the central part of the basin, and surrounded by floodplan swamps and lakes (Tenchov, 1993). Mostly the strata are grey indicating high water tables, but in the Gurkovo Formation red-beds appear indicating the onset of more arid conditions and lower watrer tables. There is some evidence of volcanic activity in the surrounding area, with major basin-wide tonsteins occurring in the Makedonka Formation (this is used to divide the formation in to two members) and Gorkovo Formation.

Coals occur mainly in the Mogilishte, Makedonka, Krupen and Gurkovo formations and their main characteristics are summarised in Table 3. In all but the Gurkovo Formaton, the coals show an eastwards increase in vitrinite reflectance (Konstantinova \& Nikolov, 1974).

\section{Fault-related basins}

South of the foreland and cratonic basins of the foreland, faultrelated basins developed within the Variscan Mountains. Although most were established during Late Carboniferous times, during the final phases of the Variscan Orogeny, some of these basins were initiated during Mississippian or early Pennsylvanian times (e.g. the Intra Sudetic Basin). However, the potential for preservation of such basins was generally very low; most were in terranes involved in Variscan processes that were subject to uplift, resulting in the erosion of several to several tens of kilometres of rock and the exhumation of highgrade metamorphic rocks (e.g. Kotková \& Parish, 2000; Scheuvens \& Zulauf, 2000; Zulauf et al., 2002a, b). Consequently, most of these basins only record a sedimentary history from middle or late Pennsylvanian times onwards. This period is characterized by widespread wrench faulting and basin formation (Arthaud \& Matte, 1977).

The resulting basins are smaller compared to their foreland and cratonic counterparts, and the strata are usually disrupted only by normal or strike slip faults. Coal rank is considerably variable, ranging from high to low volatile bituminous coals or even anthracites (Havlena, 1965; Kneuper, 1971). Basin fill is characterised by an alternation of red coal-barren and grey coal-bearing continental strata, interrupted by frequent hiatuses. Palaeogeographically, these basins formed along faults within the orogenic belt, at altitudes estimated to have been between a few hundred metres to more than $3 \mathrm{~km}$ (e.g. BecqGiraudon et al., 1996; 0pluštil 2005). The fill of these basins is, therefore, predominantly continental/non-marine, although weak temporary marine influence has been proved in some basins such as the Intra Sudetic Basin during late Viséan times (Bossowski et al., 1995). Their intra-continental position and higher altitude could result in local climatic conditions that were different from those in basins located along or near the coast in low altitudes (Opluštil \& Cleal, 2007). Particular basins were separated from each other by highland to mountainous topography. Although land-locked, it is assumed that they were drained to the Variscan foreland basins, and various basins could thus be interconnected via fluvial-valley systems (e.g. Gaitzsch et al., 1998; Schneider et al., 1998; Opluštil, 2005). Deposition in continental basins was often accompanied by

Table 3. Changing coal compositon through the Pennsylvanian Subsystem of the Dobrudzha Coalfield (data based on Tenchov \& Kulaksuzov, 1972 and Konstantinova \& Nikolov, 1974).

\begin{tabular}{|c|c|c|c|c|c|c|c|}
\hline \multirow[t]{2}{*}{ Formation } & \multirow[t]{2}{*}{ No. of seams } & \multirow{2}{*}{$\begin{array}{l}\text { Average } \\
\text { thickness (m) }\end{array}$} & \multirow{2}{*}{$\begin{array}{l}\text { Mineral } \\
\text { matter (\%) }\end{array}$} & \multirow{2}{*}{$\begin{array}{l}\text { Vitrinite } \\
\text { reflectance }\left(R_{\mathrm{r}}\right)\end{array}$} & \multicolumn{3}{|c|}{ Maceral groups (\%) } \\
\hline & & & & & Vitrinite & Liptinite & Inertinite \\
\hline Gurkovo & 11 & 2.3 & 12 & $0.61-0.84$ & 50 & 15 & 26 \\
\hline Krupen & 5 & 2.2 & 14 & $0.62-0.88$ & 52 & 14 & 19 \\
\hline Makedonka & 12 & 1.7 & 14 & $0.68-0.88$ & 48 & 14 & 20 \\
\hline Mogilishte & Up to 70 & $0.2-0.6$ & 32 & $0.75-1.87$ & 35 & 3 & 30 \\
\hline
\end{tabular}


strong, explosive acid volcanism, which generated various lava bodies, ignimbrites and volcanic ash deposits, the latter (often referred to as tonsteins) forming laterally very widespread isochronous horizons - excellent correlation markers and a source of radiometric data. Basic volcanism was less common in Pennsylvanian times but became more important from Early Permian times due to the onset of rifting processes.

\section{Saar-Lorraine (S. Opluštil, C. J. Cleal \& A. Kędzior)}

The Saar-Lorraine Coalfield straddles the Franco-German border, between Faulquemont in France and Ottweiler in Germany. It is probably the most intensively-studied of the Westphalian-aged Variscan intramontane basins, having an essentially continuous upper Duckmantian to upper Asturian succession with finelypreserved fossil faunas and floras (Schindler \& Heidtke, 2007). It was long regarded as the standard succession for the Westphalian-Stephanian stage boundary, although the evidence now suggests that the junction is a substantial non-sequence (Germer et al., 1968; Cleal, 2008b). The Saar-Lorraine Pennsylvanian succession is also important as it contains several tonsteins that have yielded radiometric dates, that can be tied to the macrofloral and palynological biozonations (Lippolt et al., 1984; Burger, 1990; Burger \& Billig, 1987; Burger et al., 1997; Gradstein et al., 2004)
It is an area of outcrop of coal-bearing Pennsylvanian strata about $80 \mathrm{~km}$ long and up to $30 \mathrm{~km}$ wide (Fig. 20), which was intensively exploited since the end of $18^{\text {th }}$ century. However, the coalfield represents only a small part of a much larger continental (Saar-Lorraine or Saar-Nahe) basin, whose former extent is indicated by deep boreholes and seismic profiles that have proved Pennsylvanian and Permian strata beneath younger Mesozoic cover (Falke \& Kneuper, 1972). The whole present-day extent of the Late Palaeozoic sediments is therefore estimated to be about 300 by $100 \mathrm{~km}$ (Korsch \& Schäfer, 1995) between Épinal, Metz, Saarbrücken and Mainz.

The basin forms a half-graben structure located along the SW-NE striking South Hunsrück Fault, which marks the boundary between the Rheno-Hercynian Zone to the north and the Saxo-Thuringian Zone to the south, and represented here by the Northern Phyllite Zone and Mid-German Crystalline Rise (Franke, 2000). The South Hunsrück Fault, which marks the northern margin of the basin, was active during the Westphalian and Stephanian deposition as a dextral strike slip, as indicated by the progressive migration of the depocentre towards the northeast (Korsch \& Schäfer, 1995). The South Hunsrück Fault was also responsible for a high subsidence rate that resulted in the accumulation of up to $5 \mathrm{~km}$ of Pennsylvanian deposits and a comparable thickness of Permian strata.

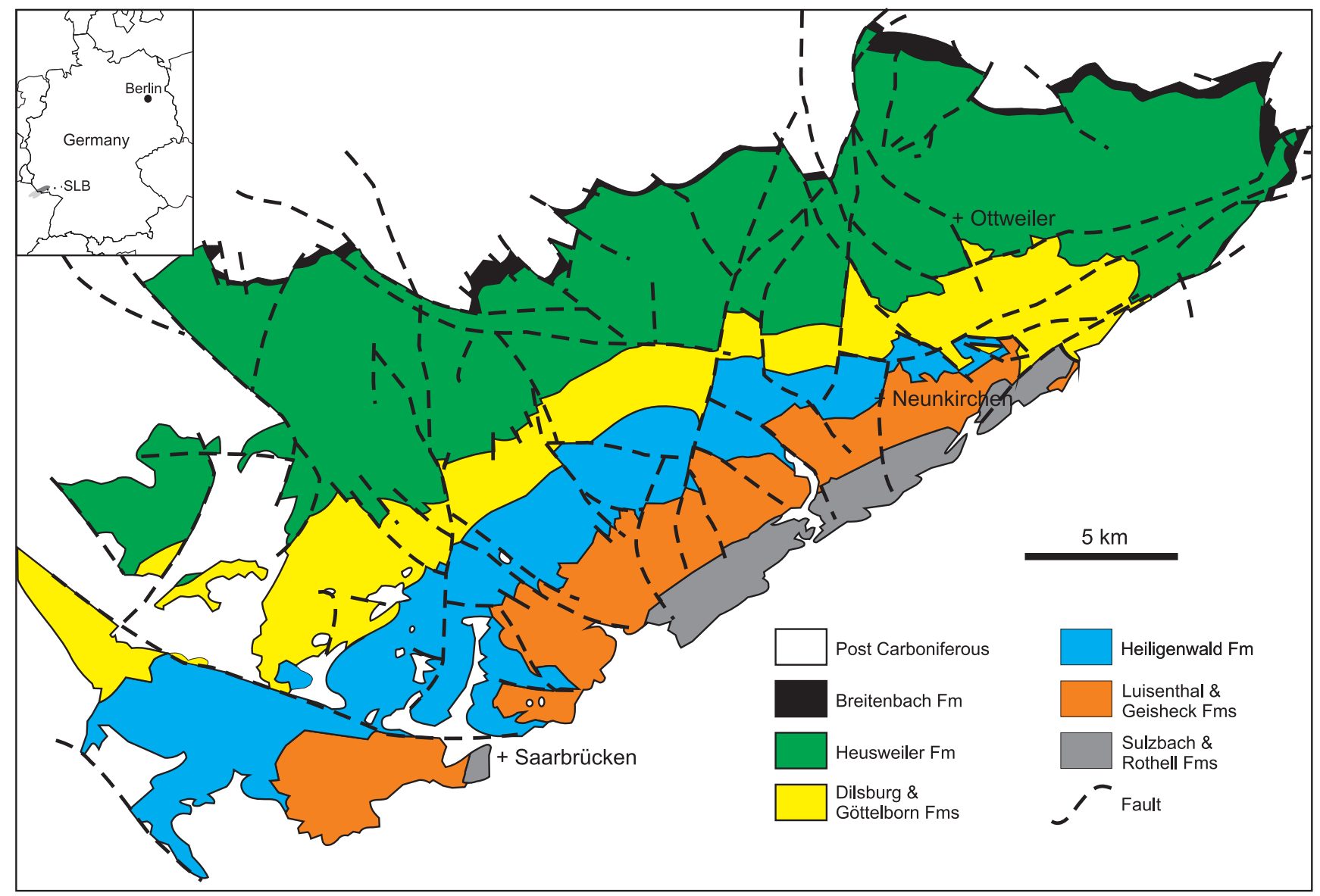

Fig. 20. Exposed portion of the Saarland Coalfield. Inset shows position of Saar-Lorraine Basin (SLB). Redrawn from Kneuper (1967). 
Pennsylvanian deposition started in the late Namurian and with several hiatuses continued to the Permian. The Late Namurian Spiesen Formation was encountered only in the borehole Saar 1, which penetrated a few tens of metres of conglomerates and sandstones arranged into a fining-up succession, and interpreted as alluvial fan deposits (Birenheide et al., 1976).

Westphalian strata are assigned to the Saarbrücken Group (Fig. 21), and include clastics derived from the Rhenish Schiefergebirge to the north (Schäfer \& Korsch, 1998). The lower part of the group, the Neunkirchen Formation, is dominated by sandstones (especially in its lower part) with subordinate conglomerates and mudstone intercalated with only thin coal seams (Schäfer, 2005) and are probably deposits of fluvial to fluvio-lacustrine origin. The depocentre was located in the French sector of the basin (Donsimoni, 1981).

Above the Neunkirchen Formation there is a small hiatus, followed by the rest of the Saarbrücken Group, which has about a hundred economically important coal seams notably in the Sulzbach and upper Heiligenwald formations. The mainly grey sediments are mostly arranged into fining-up successions, with coarsening-up cycles being much less common (Schäfer, 1986, 2005; Izart et al., 2005). This indicates that deposition was in meandering fluvial systems with well developed floodplains as a dominant environment, although lacustrine and lacustrine delta sediments can also be locally present. Conglomerate bodies up to several tens of metres thick (e.g. the Merlebach, Tritteling and Merchweiler conglomerates) are interpreted as tectonically-initiated gravel deposits in braided fluvial systems (Schäfer \& Sneh, 1983).

The top of the Westphalian succession is marked by an unconformity at the base of the Holz Conglomerate, probably the result of a transpression phase on the South Hunsrück Fault. The resulting basin uplift led to the erosion of up to $1,000 \mathrm{~m}$ of late Westphalian strata in the German part of the basin (Schäfer, 1989; Korsch and Schäfer, 1995) and so the stratigraphically highest Westphalian strata is only seen in the Lorraine area (Zone de Faulquemont). There is no evidence that even these highest beds in the Lorraine part of the basin extends above the Westphalian Stage (Cleal et al., 2003).

The depocentre of the Stephanian Ottweiler Group (Fig. 21) lies along the French-German border. The group consists mostly of red and green clastics, with subordinate grey intercalations usually in the vicinity of coal seams, and dolomitic marls and limestones. The sandstones are mostly lithic arenites to

Fig. 21. Westphalian-Stephanian stratigraphy of the Saar-Lorraine Coalfield. The lithostratigraphical units for the German part of the coalfield are after Gothan et al. (in Guthörl, 1952); Birenheide et al. (1976) and Schäfer (2005); those for the French section are after Donsimoni (1981). Formations are mostly delineated by tonsteins or important coal seams. For legend, see Fig. 4.

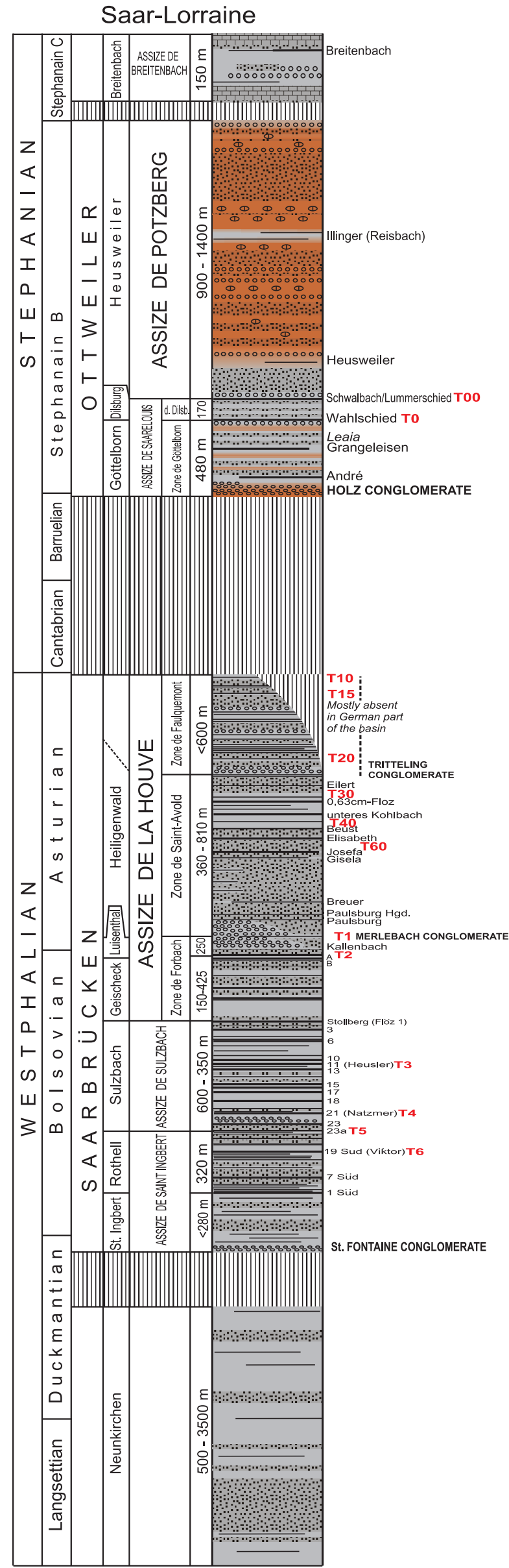


feldspatic litharenites and locally even arkoses, with about $30 \%$ of the feldspar derived from detritus from the Moldanubian granites and metamorphic rocks of the Schwarzwald and Vosges, and even from the Central French Massif (Kneuper, 1971; Schäfer \& Korsch, 1998). There are numerous conglomerates including the up to $100 \mathrm{~m}$ thick Holz Conglomerate at the base of the group. The basin drainage pattern is different from that seen in the Saarbrücken Group, with clastics being initially derived from the south and later from the southwest (Schäfer, 1986, 1989). The fluvial pattern was more braided than meandering.

Compared with the Saarbrücken Group, peat accumulation was much less in Stephanian times, with only four workable coals found in the lower part of the Ottweiller Group, and only in the German part of the coalfield. In the middle of the Heusweiler Formation is the zone of Illingen (Reisbach) Coals which until relatively recently were worked at the Schäfer Mine near Reisbach. Also typical of the middle part of the formation are palaeosoils with pedogenic carbonate nodules (caliche) forming locally compact horizons (Möhring \& Schäfer, 1990; Schäfer, 2005). There is a single coal in the uppermost part of the group, the Breitenbach Coal (= 'Grenzkohlenflöz'), which was locally workable in the northeast part of the coalfield.

\section{Intra Sudetic Basin (S. Opluštil \& A. Kędzior)}

In the Sudetic area, Pennsylvanian continental strata were deposited in the Intra Sudetic, Krkonoše-Piedmont, Mnichovo Hradiště and Česká Kamenice basins; in the Orlice Basin located further east (Fig. 22) only Permian sediments occur (Pešek, 2004). The stratigraphy is best known in the Intra Sudetic Basin thanks to the long-lasting coal mining activity. Sedimentation started during Viséan times and, except for a number of hiatuses, lasted until Triassic times (Fig. 23). In Asturian times, deposition spread out west from the Intra Sudetic Basin into the other Sudetic basins (except the Česká Kamenice Basin where it started in late Stephanian times). From early Stephanian times onwards, basins of the Sudetic area were connected with the central and western Bohemian area.

The Intra Sudetic succession is arranged into upward-fining cycles and contains locally more than 60 coal seams, many of them of economic size. Most coals are in the Žaclér Formation, especially in the Lampertice and Prkenný Důl - Žd'árky members; the Petrovice Member has only thin coals. The Petrovice Member contains some red-beds but they lack caliche deposits (Skoček, 1993). The formation was deposited on an alluvial plain dominated by braided to meandering rivers. Deposition of the youngest part of the formation was accompanied by strong volcanic activity that produced the laterally widespread volcano-clastic Křenov rhyolitic tuff, which is up to $100 \mathrm{~m}$ thick, as well as some other rhyolitic tuff bodies and up to tens of metres thick melaphyr extrusions. The Křenov tuff has yielded a $\mathrm{Ar}^{40} / \mathrm{Ar}^{39}$ plateau age of 309.0 $\pm 3.7 \mathrm{Ma}$ (Hess et al., 1985).

The rich macroflora of the Žaclér Formation has been systematically studied by many authors (e.g. Němejc, 1933, 1953a, 1958) who have provided floral lists from the roof shales of most coal seams. Later, Šetlík (1977) and Šetlík (in Tásler et al., 1979) continued this research and correlated strata of the Žaclér Formation with similar strata in the continental basins of Central and Western Bohemia. The first analysis of plant assemblages of the Intra Sudetic Basin was published by Purkyñová (1986). Systematic palynological research in the Czech part of the Intra Sudetic Basin started during the 1960s by Kalibová-Kaiserová (1956). However, most palynological work was done by Valterová, who summarised her results in a PhD thesis (Valterová, 1979).

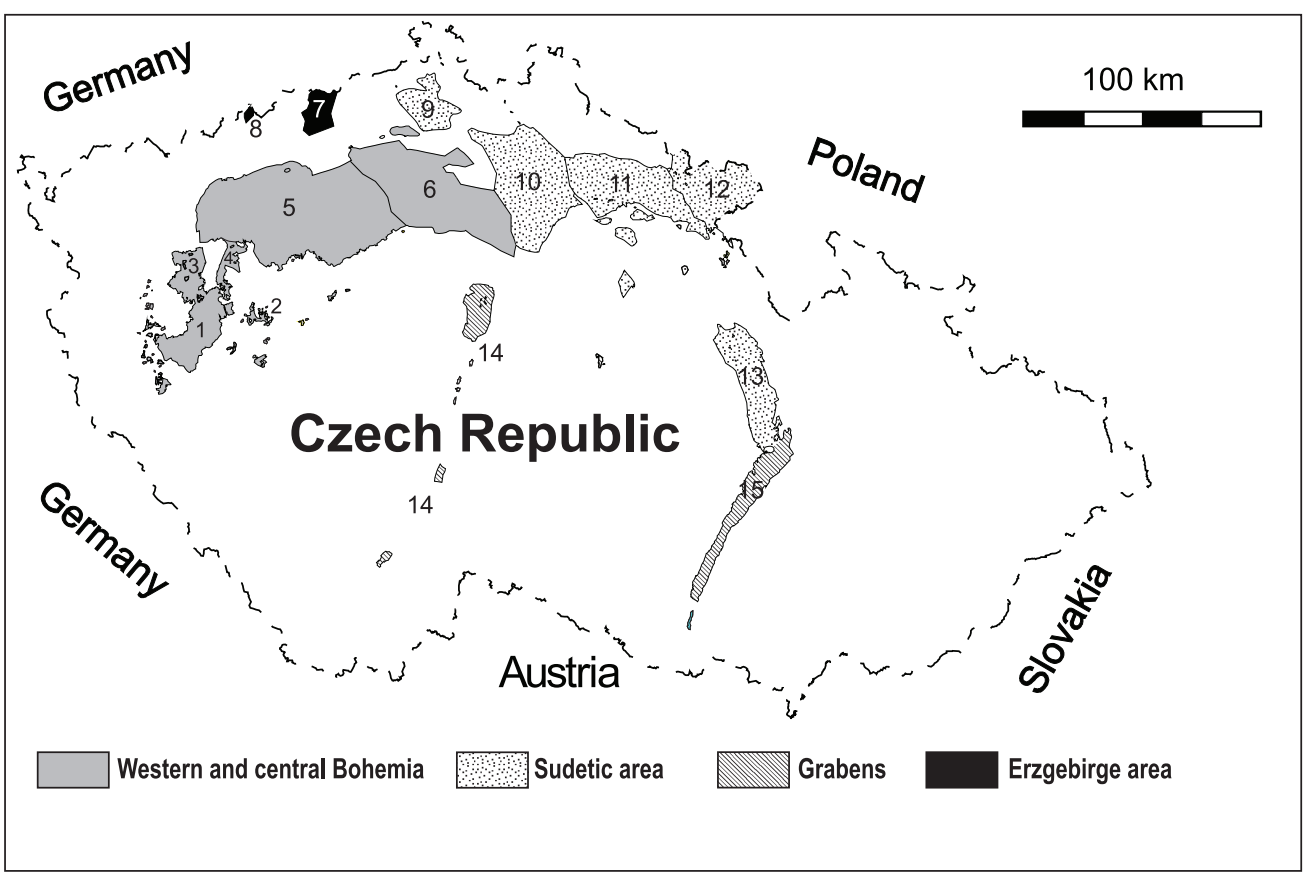

Fig. 22. Late Palaeozoic continental basins of the Czech Republic and their regional subdivision. Westphalian to Early Stephanian strata occur only in the basins of central and western Bohemia, and the Sudetic and Krušné hory Mountains areas. Basins: 1 - Plzeñ, 2 - Radnice, 3 Manětín, 4 - Žihle, 5 - KladnoRakovník, 6 - Mšeno-Roudnice, 7 Mikulov, 8 - Brandov, 9 - Česká Kamenice, 10 - Mnichovo Hradiště, 11 - Krkonoše Piedmont, 12 Intra Sudetic, 13 - Orlice, 14 Blanice, 15 - Boskovice. 


\section{Intra Sudetic Basin}

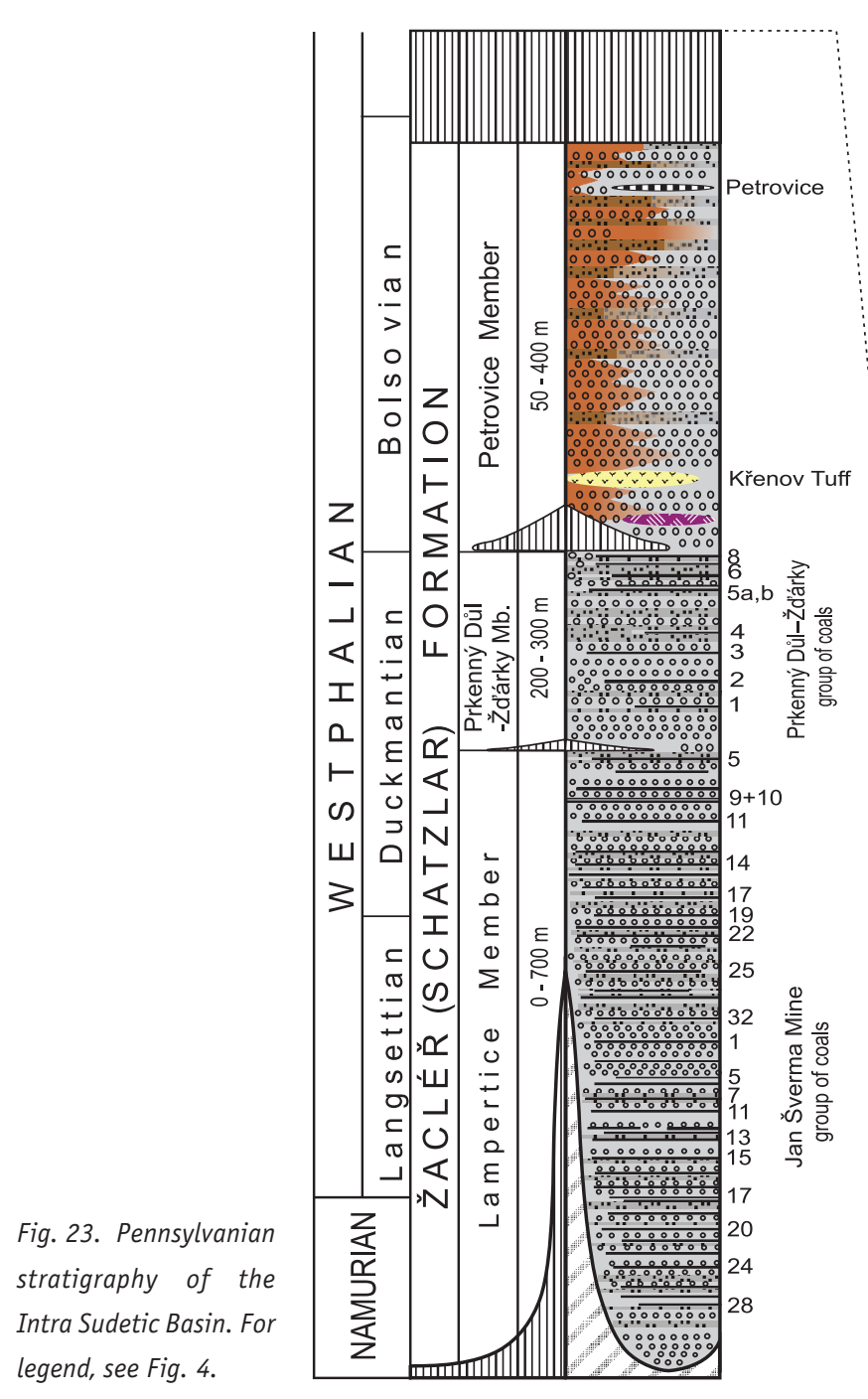

The Odolov Formation, which is separated from the Žaclér Formation by a basin-wide hiatus, consists of two upward-fining units: the Svatoňovice and Jívka Members. The Svatoňovice Member is composed of fluvial cycles with mudstone as a prominent part of the cycles. The mudstones are mostly red to rusty and locally contain pedogenic carbonate nodules (Tásler et al., 1979), although kaolinite and other products remain dominant suggesting lateritic weathering in the source area (Havlena, 1964). In the upper part of the member, mudstones become more often grey and the cycles contain the four coal seams of the Svatoňovice group. The overlying Jívka Member includes fluvial to fluvio-lacustrine strata dominated by feldspatic sandstone and conglomerates containing abundant remains of silicified woods and occasional intercalations of barren reddish mudstones. The silicified woods are similar to those found in the Týnec Formation in central and western Bohemia (Šetlík, 1977), and are the result of precipitation from silica-rich solutions produced by chemical weathering of feldspars due to

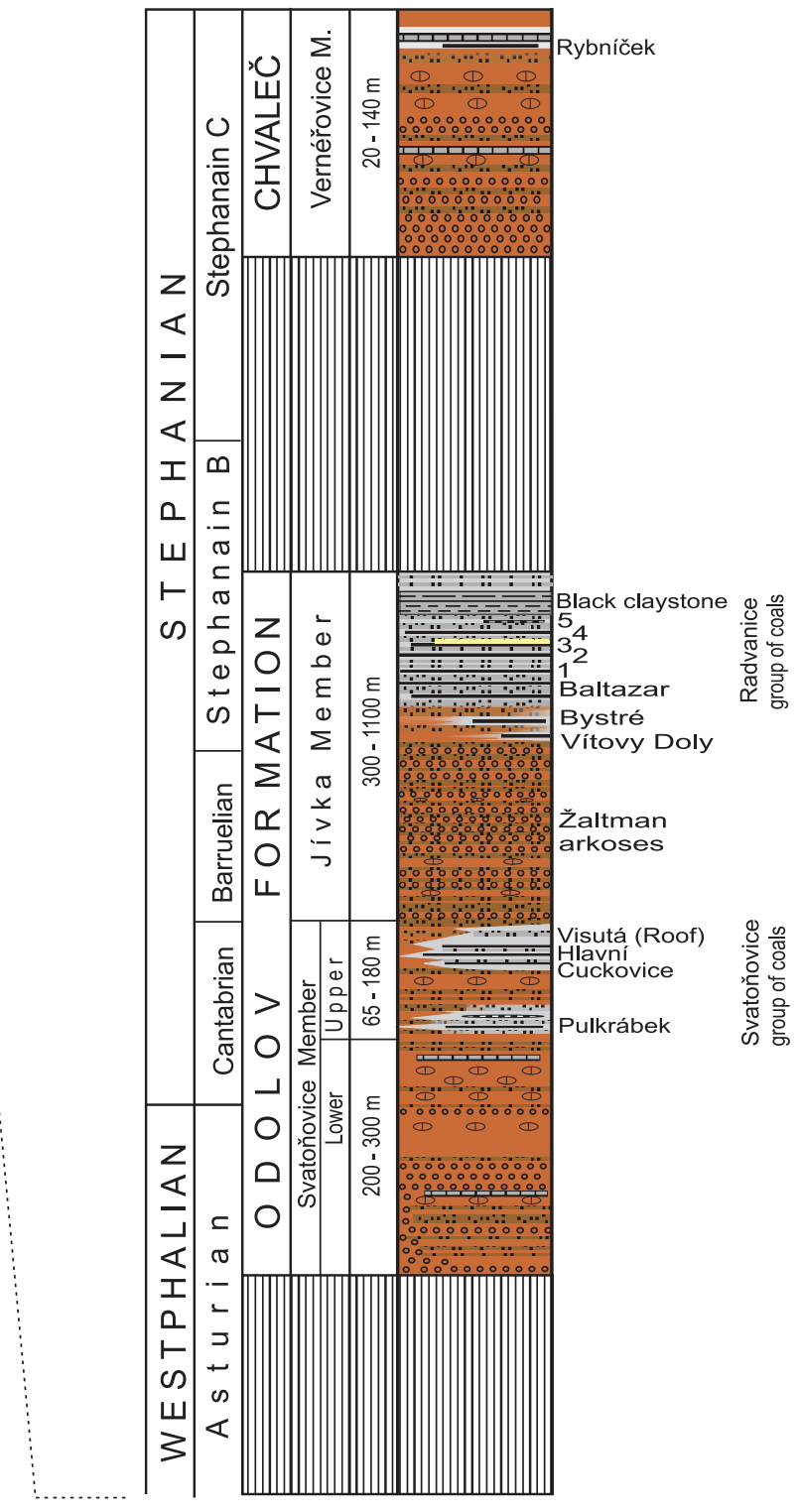

the variation of water table levels under a seasonal climate (Matysová et al., 2008; Mencl et al., 2009). Several local groups of coals appear in the upper part of the member, the most important being the Radvanice group near top of the unit.

\section{Central and Western Bohemia (S. Opluštil \& A. Kędzior)}

In central and western Bohemia, Pennsylvanian strata cover about $6,000 \mathrm{~km}^{2}$, of which $3,500 \mathrm{~km}^{2}$ are exposed; the rest is covered by younger, mostly Cretaceous sediments. The complex of continental strata is formally subdivided into Plzeň, Manětín, Žihle, Radnice, Kladno-Rakovník and Mšeno-Roudnice basins (Fig. 22), but which originally consisted of a single depositional basin located on the Teplá-Barrandian Zone. This unit is situated between the Saxo-Thuringian Zone to the north and the Moldanubian Zone to the south, which are interpreted as terranes of Armorican affinity (Franke, 2000). The basement consists mostly of late Proterozoic weakly 
metamorphosed shales and greywacke with volcanic and chert intercalations, and subordinate medium metamorphic rocks cut by Cadomian and Variscan granitoids or unmetamorphosed but folded Early Palaeozoic sediments (Pešek, 2004).

Havlena \& Pešek (1980) characterized this basin complex as a simple asymmetric mega-graben formed on the TepláBarrandian block, subsiding along the WSW-ENE-striking Central Bohemian and Litoměřice fault zones (terrane boundaries). In contrast, Pašek \& Urban (1990) emphasised the role of wrench faults striking NW-SE, related to the collision between Gondwana and Baltica (Arthaud \& Matte, 1977). Based on the slopes of the axis of the main valley and the estimated distance from the coast, Opluštil (2005) estimated the altitude of the basins in middle Westphalian times to be about 1,000 m or a little less above sea level.

The basin-wide alternation of coal-bearing predominantly grey and coal-barren red-bed units was used as the basis for the lithostratigraphical subdivision of the basin fill shown in Fig. 24 (Weithofer, 1896, 1902). The Radnice Member consists of fluvial, lacustrine to lacustrine delta and colluvial sediments that formed the fill of an incised or tectonically formed system of river valleys, with a palaeotopography at the depocentre of up to $200 \mathrm{~m}$ (Opluštil, 2005). Reconstruction of the valley system indicates that the eastern part of the area was drained to the northwest, probably into the Variscan foreland (Gaitzsch et al., 1998; Opluštil, 2005). Fluvial sediments were deposited in meandering to braided fluvial systems. Channel fills mostly occupy valley axes, whereas floodplain sediments with coal seams are located usually along valley margins, and colluvial sediments (mostly breccias) are located along the foothills of basement outcrops. Coal seams are concentrated in the Pilsen, Radnice and Lubná groups. Some red-beds occur along the basin margin, probably derived from reworking of laterite weathering crusts (Skoček \& Holub, 1968). Widespread volcanoclastic horizons are in the northern part of the KladnoRakovník Basin accompanied by rhyolite effusions of a cumulative thickness of over $100 \mathrm{~m}$. Lacustrine and lacustrine delta sediments are much less common and quite thin, being best developed in the roof of some coal seams.

The Nýřany Member is separated from the Radnice Member by a basin-wide hiatus, related to the Leonian phase (0pluštil \& Pešek, 1998) and spread out quickly over most of the basin complex. The member is of fluvial origin, and is characterised by a predominance of coarse- to medium-grained arkoses with pebble admixture over fine-grained sandstone and mudstone intercalations. Sediments are arranged into 10 to $20 \mathrm{~m}$ thick upward fining cycles, terminated occasionally with thin and only locally mineable coal seams. These seams are divided into the Touškov, Nýřany, Chotíkov and the youngest Nevřeň groups (Pešek, 1994). Sediments of the Nýřany Member represent deposits of a large braidplain supplied with clastics mainly from a source area located south of the basin, in the Central Bohemian Pluton (Pešek, 1994).

\section{Central and Western Bohemia}

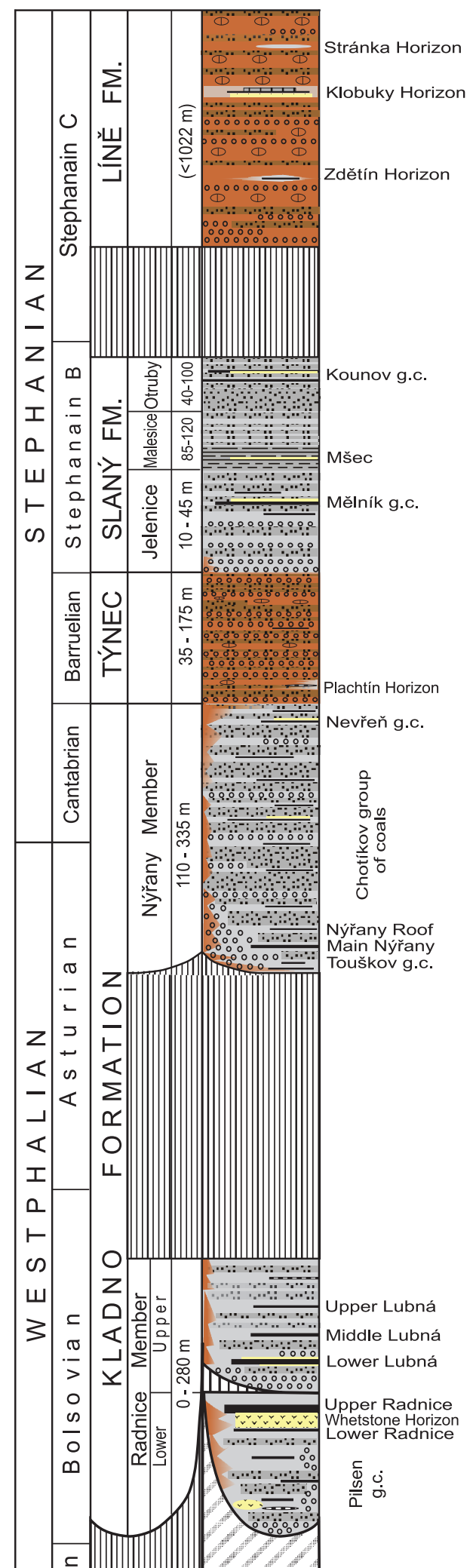

Fig. 24. Lithostratigraphy of the central and western Bohemia. For legend, see Fig. 4. 
The character of deposition typical for the Nýrany Member continued into the overlying Týnec (Lower Red) Formation (Barruelian), as indicated by similar facies and architecture. The main difference between the two units is the red colour of the fine-grained sediments and absence of coal seams in the Týnec Formation, interpreted as a response to climatic change from humid to drier or (?) more seasonal conditions (0pluštil \& Pešek, 1998; 0pluštil \& Cleal, 2007). Plant remains were found mostly in local grey mudstones and indicate a Barruelian age (Wagner, 1977; Šimůnek in Pešek, 2004).

The following Slaný (Upper Grey) Formation (Stephanian B) consists of fluvial, lacustrine and deltaic strata. The lower part of the unit is represented by sediments deposited in similar fluvial systems to those represented in the Týnec Formation but under more humid climatic conditions that favoured mire formation (Mělník group of coals). These basal and locally coalbearing fluvial strata of the Jelenice Member are sharply overlain by a more than $100 \mathrm{~m}$ thick, upward-coarsening lacustrine to lacustrine delta sequence (Skoček, 1990). It starts with a horizon of dark laminated claystone traceable over the whole basin complex up to the Polish part of the Intra Sudetic Basin, and represents deposits of one of the largest Stephanian lakes in Euramerica. The lamination is interpreted in a term of seasonal climate (Skoček, 1990, Lojka et al., 2009). Laminites are overlain by prodeltaic heterolites, passing upward into ripple bedded sandstones, and then to medium- and coarse-grained arkosic sandstones occasionally with pebbly admixture, interpreted as fluvial sediments. The upper part of the Slaný Formation consists of fluvial strata containing the laterally persistent fluvio-lacustrine horizon of the Kounov group of coals.

The youngest Pennsylvanian sediments in central and western Bohemia belong to the Líně (Upper Red) Formation (Stephanian C - ?Autunian). It is separated from the underlying Slaný Formation by a basin-wide erosional surface with relief of up to $200 \mathrm{~m}$ (Skopec et al., 2000) and also by a floristic break (Šetlík, 1977), which indicates the existence of a hiatus between these two units. Deposition of the Líně Formation took place in generally drier, probably seasonally-wet climate comparing to more humid one of the previous unit (0pluštil \& Cleal, 2007). That is why sediment of the Líně Formation, especially the mudstones, is predominantly red coloured with frequent horizons of pedogenic carbonate nodules or calcretes. The presence of horizons of grey or mottled mudstones a few tens of metres thick, locally with cherts, volcanoclastics, lacustrine carbonates or even thin coal seams may indicate periods of temporarily humid climate.

\section{Zwickau-Oelsnitz (St. Schultka \& J.W. Schneider)}

The term Erzgebirge 'Basin' refers to the $2,100 \mathrm{~km}^{2}$ area of Late Palaeozoic deposits in south-western Saxony that currently flanks the northern side of the Erzgebirge, rather than a specific basin in geotectonic terms (Fig. 25). The 'basin' was discontinuously filled with molasse deposits of the Variscan Orogen, with sedimentation being interrupted by long periods of non-deposition and erosion of older basin fill. Each basin was controlled by different geodynamic regimes and therefore developed independently of its precursors.

The Zwickau-Oelsnitz Basin is of post-orogenic origin, formed at the intersection of regional deep faults: the NW-SE Gera-Jáchymov Zone, the SW-NE detachment between the Erzgebirge and the Saxonian Granulite Massif, the N-S PlauenDessau-Leipzig Zone (the 'Naab' N-S element), as well as subordinate E-W lineaments (Fig. 25). The basin structure was originally aligned mainly in a NNW-SSE to N-S direction, changing to a more NE orientation when the first coal seams (Segen-Gottes seams) were deposited. The origin of the basin and this change in direction of tectonic activity may be related to the Leonian Tectonic Phase. Continuous synsedimentary
Fig. 25. Simplified geological map of the tectonic structures of the Erzgebirge Basin. Modified after Schneider et al. (2005b).

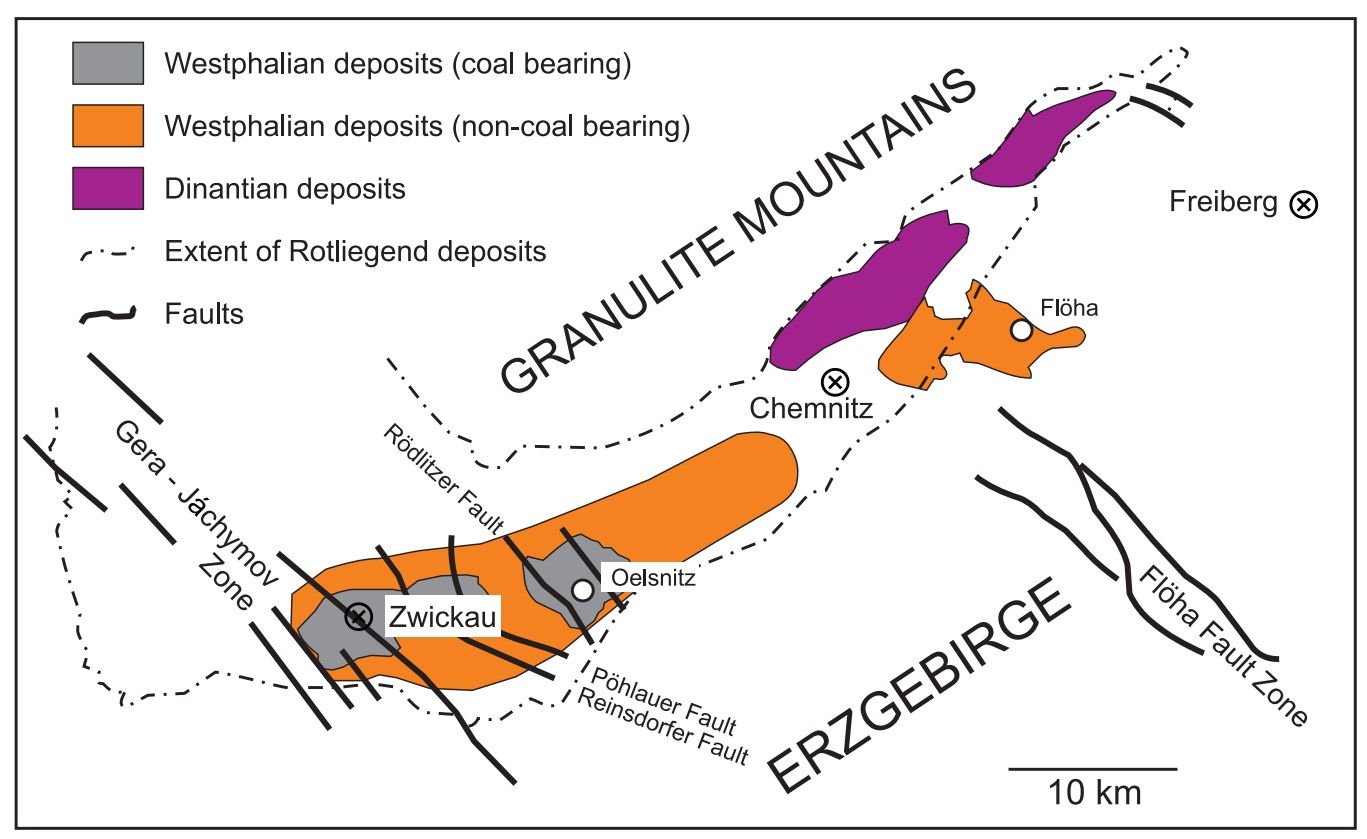


tectonic movement affected sedimentation patterns. This was also influenced by a relatively restricted extension of the original basin, and synsedimentary volcanic activity as shown by the 'Cainsdorfer and the Reinsdorfer Melaphyr' and at least three pyroclastic layers under the Amandus Seam (?Ludwig Seam), around the Rußkohlen Seam and in the Lehenkohle Seam.

The Zwickau and Oelsnitz sub-basins were separated by a synsedimentary swell and the Mülsenfeld fan. The coal swamps formed in the centre of the sub-basins were only a short distance from the source areas of sediments, resulting in rapid changes in grain size, pebbly material and coals seams often strongly-split by sand- and siltstones and dirty bands. On the other hand, good coals up to $10 \mathrm{~m}$ thick are locally developed. The successions of the Zwickau and Oelsnitz sub-basins are referred to as the Zwickau and Oelsnitz formations, respectively.

The Zwickau Formation was deposited with a basal unconformity on a folded basement of Ordovician to Devonian age, and locally on Carboniferous basalts. The formation is erosively overlain by Lower Permian sediments. The section is completely built up by grey facies, with a wide spectrum of sediment-types typical for restricted limnic basins, including volcanic ashes and calcareous sediments (Fig. 26). The formation consists of 11 fining-upwards cycles, grouped into three subformations (Schneider et al., 2005). The cycles mostly consist of a basal conglomerate or coarse pebbly sandstone overlain by finer-grained coal-bearing strata. Sediment was initially derived from sources to the south, but in the middle Marienthal-Pöhlau Subformation this became more variable with both southern and northern sources due to synsedimentary tectonics. The lower part of the formation also has basalt flows (the Cainsdorf and Vielau/Reinsdorf 'melaphyres') and tuff bands occur throughout the succession. The fossil biotas of the Zwickau Formation have been discussed by Döring et al. (1988), Schneider \& Rößler (1996), Schneider et al. (2005b), Schultka $\&$ Kahlert (in press) and Witzmann et al. (in press).

\section{Tectono-sedimentary history of the basins (A. Kędzior \& S. Opluštil)}

This report is primarily concerned with events that took place during late Westphalian and early Stephanian times. However, it is impossible to interpret these without an understanding of events throughout the Pennsylvanian Subperiod. The following description of sedimentary environments in this chapter therefore starts with the Pendleian Substage; older strata contain only minor, rarely economic coal-seams, and thus can be omitted here.

\section{Pendleian-Alportian substages ('Namurian A')}

Deposits of this age are present mostly in basins of the north Variscan foreland, and to a much lesser extent also in some continental basins within the Variscan Mountains. In Europe,

\section{Erzgebirge Basin \\ Zwickau - Flöha}

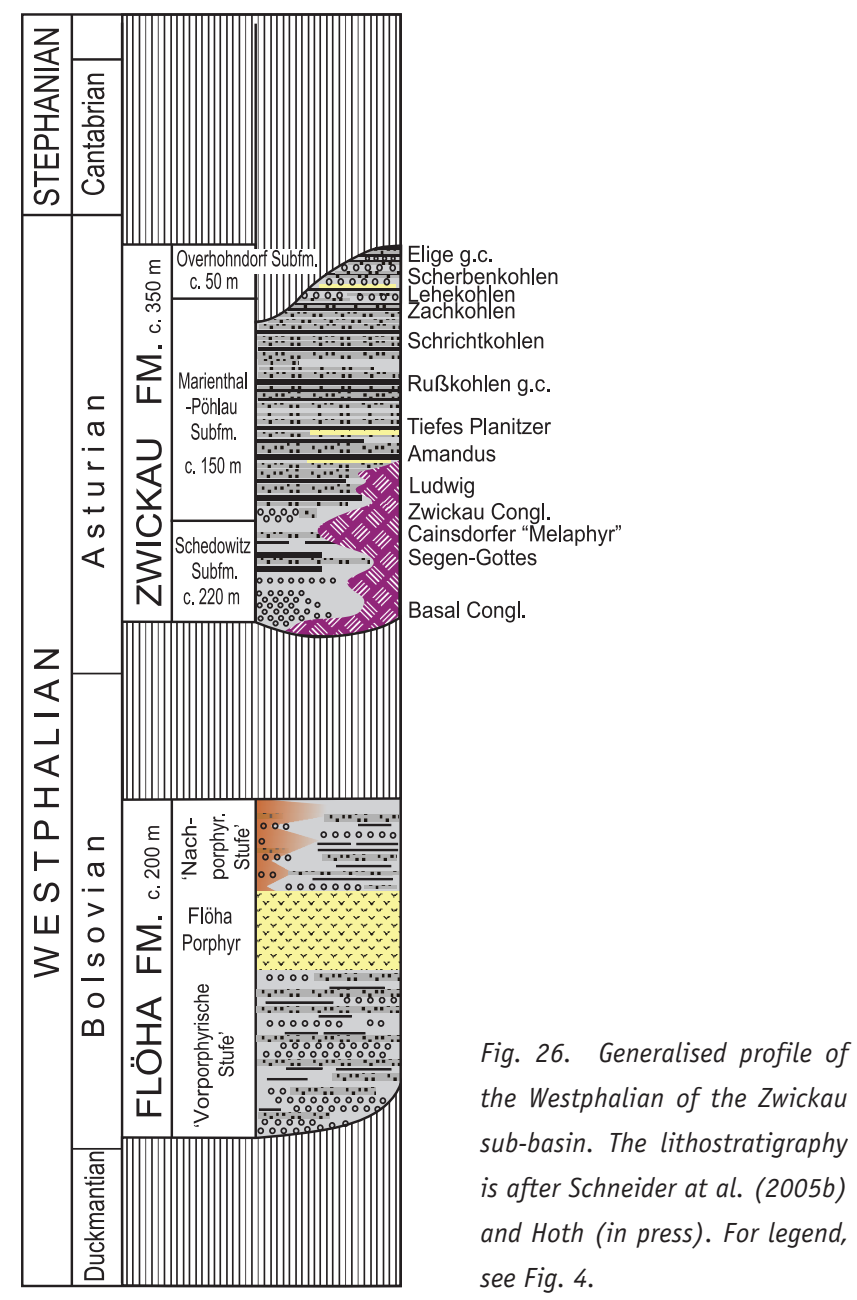

there is an eastwards transition from marine conditions (Pennines, South Wales and Ruhr-Osnabrück) to deltaic and shallow shelf conditions (Upper Silesian and Lublin), to coastal plain and lagoonal conditions (Dobrudzha). In the Sydney Basin in Canada, however, deposits of this age are in shallow lacustrine to alluvial fan facies with some evidence of marine influence (Gibling et al., 2004). The intramontane basins generally have no deposits of this age, except for Saar-Lorraine and the Intra Sudetic basins, with several tens and c. $200 \mathrm{~m}$ of alluvial fan to fluvio-deltaic conditions respectively.

\section{Mississippian/Pennsylvanian boundary}

At the Mississippian-Pennsylvanian boundary there is a stratigraphical gap of varying size in most of the basins analysed (the mid-Namurian boundary), which has been related to the Erzgebirge Phase of Variscan deformation. In the Dobrudzha Coalfield the hiatus includes the Arnsbergian to Langsettian substages, in Upper Silesia the Chokerian and Alportian substages, and in the Lublin-Volhynia Basin the uppermost Alportian and all of the Kinderscoutian substages. 
Surprisingly, however, no evidence of tectonic movement related to the Erzgebirge Phase has been found in the British, North Sea or Ruhr basins. The question thus arises, why did strong tectonic deformations that remodelled sedimentary patterns in several basins not affect (or had only a minor influence) in north-western Europe?

The Erzgebirge tectonic phase coincided with the midCarboniferous Eustatic Event, which according to Saunders \& Ramsbottom (1986) '... began with a regression that is recorded in most shelf sequences, followed by short transgression and the event ended with a transgression that flooded large shelf areas'. This regression seems to have been a global event, traceable over thousands of kilometres from Australia through China, Europe to Canada and the United States. The erosion representing the mid-Namurian hiatus undoubtedly was preceded by a phase of uplift; the estimated thickness of sediment removed during this episode lasting about $2 \mathrm{Ma}$ has been estimated in Upper Silesia Coal Basin to be c. 140 m (Matl, 1966). When sedimentation recommenced in the Upper Silesia, Sydney and Dobrudzha basins, conditions had changed to fully continental. The Intra Sudetic and Lublin-Volhynia basins were not affected by such changes due to their different palaeotectonic positions (intramontane and cratonic, respectively). In the South Wales, Pennines and Ruhr basins, in contrast, although subsidence rates were relatively low (Gayer et al., 1993; Kombrink et al., 2008) they exceeded the regression rate of the world oceans and so sedimentation continued under essentially marine conditions with only limited evidence of stratigraphical break.

\section{Kinderscoutian-Marsdenian substages ('Namurian B')}

These substages are only fully developed in those basins unaffected by the Erzgebirge tectonic movement. In the Pennines, South Wales, North Sea and Ruhr basins there was a gradual and systematic shift from fully marine to paralic and lower delta plain conditions. The British sequences are coalbarren and only three coal seams have been found in the Kaisberg Formation of the Ruhr Basin. Further east, where this interval is partly represented (e.g. Upper Silesia) there is also a general trend towards more continental conditions.

\section{Yeadonian Substage ('Namurian C')}

A general trend of environmental change can clearly be observed. In those basins that were characterized by marine settings, paralic conditions played an increasingly important role (Pennines, South Wales, North Sea); paralic conditions were replaced by deltaic conditions (Ruhr Basin); and the bed-load dominated rivers were converted into mixed-load suggesting faster flow-rates (Upper Silesia). In the Intra Sudetic and Lublin-Volhynia basins, sedimentation was renewed under similar conditions as before, but slightly shifted towards more coarse-grained deposition. In the Canadian Maritimes (Cumberland Basin), following a stratigraphical gap, sedimentation of thick alluvial deposits of Boss Point Formation marks a significant reconstruction of depositional systems (Davies \& Gibling, 2003). Similar changes are known from the Upper Silesia Coal Basin, but there they can be seen in the ChokerianAlportian substages. In many cases, the change of sedimentary environments is very subtle and the boundary between the Marsdenian and Yeadonian substages are mostly located on the basis of macrofloral records, except in the marine/paralic basins where marine faunas are present. In most basins, there is an increase in the quantity of coal, albeit usually as thin seams.

\section{Langsettian Substage ('Westphalian A')}

Early Westphalian times saw a further gradual shift towards more continental conditions. Deposition in the Pennines, South Wales, North Sea, Limburg and Ruhr basins took place in lower delta plain settings, resulting in thin, usually discontinuous coal seams and numerous marine bands. In the other basins (except Lublin-Volhynia) deposition was in purely continental settings connected with alluvial plains constructed by mixedload rivers (Upper Silesia, Saar-Lorraine) or bedload rivers (Intra Sudetic Basin). The Lublin-Volhynia sequence shows features indicating both fluvial incised valley infill and shallow shelf/delta plain environments. The number of coals in all basins markedly increases, with up to 70 seams in the Dobrudzha and Upper Silesia coalfields.

The Namurian-Westphalian boundary is easily identified in the marine influenced basins (Pennines, South Wales, North Sea, Limburg, Ruhr) where it is placed at the Subcrenatum (Sarnsbank) Marine Band. In Upper Silesia, the lacustrine Hubert freshwater fauna horizon has been interpreted as a distal expression of the regional transgression that produced the marine horizons of western Europe. No similar horizon has been identified in the Lublin-Volhynia Basin probably due to its poorly developed connection with world oceans. In the intramontane basins, where there are no marine faunas and the lithological change is very subtle, the boundary is located according macrofloral evidence.

\section{Duckmantian Substage ('Westphalian B')}

The Langsettian-Duckmantian boundary is easily located in the cratonic and foreland basins studied. In the Pennines, South Wales, North Sea, Limburg and Ruhr basins it is placed at the Vanderbecki or Katarina Marine Band, and in the LublinVolhynia Basin this is regarded as equivalent to a brackish water Dunbarella horizon. In Upper Silesia, the boundary is located at a tuff horizon, which is close to the horizon from which the Andrzej fresh water fauna has been described. In the intramontane basins, however, it is more problematic as the 
macrofloras do not show a major change at this level, nor is there any significant change in facies or petrographic composition.

The South Wales, Pennine, North Sea, Limburg, Ruhr and Lublin-Volhynia sequences of this age show a continuing progressive shift towards more continental settings, with deltaic environments prevailing; in the Lublin-Volhynia Basin, there is even a shift to upper delta and alluvial plain settings. In such conditions, thick coal seams and seat earths developed, associated with increasing sandstone content, together with a reduction of marine bands and brackish fauna horizons. The Upper Silesia sequence is characterized by continuous deposition on an alluvial plain laid down by meandering and probably anastomosing rivers, resulting in numerous but usually thin coal seams.

At the end of Duckmantian times, the quiescent deposition under low flow regimes is widely replaced by high-energy braided river systems. In the Dobrudzha Coalfield, swampy and lacustrine conditions were initially replaced after regional erosion by fluviatile sedimentation of braided rivers and later by mixed-load rivers probably after having exhausted the local source area. Within the intramontane basins (Intra Sudetic and Saar-Lorraine) the sediments were laid down on alluvial plains characterised by braided to meandering rivers, with extensive peat-generation in the associated floodbasins. Surprisingly, the strong volcanic activity noted in the Ruhr Basin is not reflected in other basins except Saar-Lorraine, where the tuff and kaolinite horizons have been used for stratigraphical correlation.

The presence of local stratigraphical gaps (Saar-Lorraine, Intra Sudetic), erosional surfaces (Dobrudzha), abundant pyroclastic horizons (Ruhr and Saar-Lorraine) and abrupt changes in the river pattern (Upper Silesia) during late Duckmantian times suggest tectonic disturbance was occurring within the Variscan Orogen.

\section{Bolsovian Substage ('Westphalian C')}

There was a significant change in depositional patterns during Bolsovian times, especially in the British basins. The lower part of the substage is characterized by upper delta plain deposits, which is replaced in the upper part of the substage by characterised by deposits of bed-load dominated rivers on alluvial plains. This change is also accompanied by the disappearance of marine influence; the stratigraphically youngest marine horizon in these basins is the Cambriense Marine Band and its equivalents (the Nibelung horizon in the Ruhr Basin and the Arnold fresh-water fauna horizon in Upper Silesia). In the northern part of the Lublin-Volhynia Basin, only impoverished faunas have been found in a few boreholes, and so establishing identifiable faunal horizons there appears doubtful. On other hand, the rapid change in depositional conditions fits very well with other features described from, for example, the Central and West Bohemian basins or Dobrudzha Coalfield. However a delicate timing shift is observed and the presence of short-term hiatuses supports pre-Leonian tectonic instability; this is manifested also by strong volcanic activity in the Ruhr, Saar-Lorraine and Central and West Bohemian basins.

Deposition during Bolsovian times took place almost exclusively in continental settings. As was mentioned above, the upper parts of the Pennine and South Wales successions contain deposits laid down on broad braidplains with no marine bands. The presence of red-beds (Etruria Formation) that had evolved from grey deposits in the Pennines due to fallin water tables supports the model of alluvial facies prograding through time, and by the end of Bolsovian times such conditions had spread over most of the basin. In the Ruhr Basin, sandstone-content increases upward and in the upper part of the succession only brackish faunas can be found (Lembeck Formation). Similar features have been noted in the Lublin-Volhynia Basin and Dobrudzha Coalfield, both characterized by meandering or high sinuosity types of rivers. In the Upper Silesia Coal Basin, only lower Bolsovian deposits are known, having been deposited by distal braided rivers since Duckmantian times (Eaziska Beds of the Cracow Sandstone Series).

Thick Bolsovian sequences are known in all the intramontane basins studied. Sedimentation in the Central and West Bohemian Basins starts with the Bolsovian Radnice Member (Kladno Formation) within incised or tectonically formed valleys systems, infilled mostly by fluvial deposits. In the Saar-Lorraine and Intra Sudetic basins, the same conditions existed as seen in the Duckmantian Substage. All of these basins show strong volcanic activity, manifested by the presence of thick (tens of metres up to $100 \mathrm{~m}$ ) pyroclastic deposits.

\section{Asturian Substage ('Westphalian D')}

In many of the basins described here (Pennines, North Sea, Bristol-Somerset, Centra Bohemia, Intra Sudetic Basin, Upper Silesia) the lower Asturian Substage is missing due to the Leonian Phase; in other basins (South Wales, Dobrudzha) short hiatuses are present. However, no clear pattern of hiatusdistribution can be observed.

Another feature that characterized the Asturian subage was the localised development of red-bed facies, pointing to an aridisation of the sedimentary environments in certain (but not all) areas. During Asturian times, there is a divergence in the development of the Pennine and North Sea basins on the one hand and the South Wales Basin on the other, involving both the time span of the stratigraphical gap and the overall depositional styles. The Pennines sediments are connected with a well-drained floodplain dominated by clastic fines (Etruria Formation) later replaced by deposition under relatively high water table conditions of grey strata with fresh-water 
limestones and thin coal seams (Halesowen Formation). This in turn was replaced by a well-drained alluvial plain environment with shallow lakes formed under drier (? semi-arid) climate (Salop Formation). In South Wales, in contrast, sedimentation took place continuously with no changes from Bolsovian times on a broad braidplain, until the top of the Asturian Substage where there is an apparent lithological change to finer-grained deposits of meandering to anastomosing river systems.

The early Asturian deposits of South Wales are similar to those from the 0snabrück area in northwest Germany, where the lower part of the succession is dominated by coarsegrained deposits with a few coal seams, but the upper part lack coals. The coal seams are usually associated with pyroclastic sediments (Köwing \& Rabitz, 2005, fig. 4). Some non-marine bivalves have been found at the Bolsovian-Asturian boundary and several meters above (Zweibänke and Dreibänke coal seams) and foraminifers occur around the Itterbeck coal seam.

Deposition in the Upper Silesia Coal Basin started in late Asturian times under similar conditions to those seen in the early Bolsovian. There is no significant change of sedimentary environments associated with the stratigraphical gap, which is identified mainly using macrofloral biostratigraphy (Kotasowa, 1979). The Saar-Lorraine is a third basin (in addition to South Wales and Lower Saxony) where sedimentation was not halted by movements of the Leonian Tectonic Phase. The deposits were laid down on an alluvial plain characterised by a fluvial meandering system, but with more intensive tectonic movements creating relief and accommodation space sufficient for braided channels to develop, where thick sediments of amalgamated sandstone bodies were deposited. The Asturian succession contains numerous coals, which together with pyroclastics, are used as regional correlative horizons.

The Dobrudzha Coalfield has a very complex Asturian sedimentological history. At least two erosional surfaces separate particular units and the related hiatuses can be linked with tectonic movements of the Leonian Phase. Sedimentation took place under fluvial conditions on an alluvial plain constructed by a braided river system with small areas of accumulation of peat and fines. The Lublin-Volhynia Basin lacks Asturian deposits.

Both of the Czech intramontane basins (Central and West Bohemia and Intra Sudetic) record Leonian Phase movement, with a stratigraphical gap spanning the uppermost Bolsovian to middle Asturian substages. In the Central and West Bohemia Basin the deposits were accumulated by braided-type rivers on a broad alluvial plain, and on the flanks of the fluvial system small peatlands developed producing thin and discontinuous coal seams. After the hiatus, sedimentation in the Intra Sudetic Basin resulted in red-bed facies of the Svatoňovice Member (Odolov Formation), with fining-upward fluvial cycles with well developed mudstone members. At the top, the red-beds are replaced by greyish sediment with coals.

\section{Cantabrian Substage}

Coals are only known from the lower part of this substage in Variscan Euramerica. In the Pennine Basin, only red-beds facies of this age have been described, deposited on a well-drained alluvial plain with locally developed shallow lakes (Waters \& Davies, 2006). Southern Britain (South Wales, Forest of Dean, Bristol-Somerset, 0xfordshire) shows some coals but their occurrence is limited to the lower Cantabrian Substage. The western and eastern parts of the South Wales Basin differ significantly in the dominant fluvial style present. In the western and central area were meandering to anastomosing river systems with well-developed overbank areas of clastic fines and peat accumulation. In the eastern part, in contrast, after a significant stratigraphical gap, deposits are of a braided fluvial system with coal seams; these deposits are thought to be equivalent to the Forest of Dean Pennant Sandstone Formation.

The end of Carboniferous deposition in many of the studied basins was due to tectonic inversion of the foreland. This phase is also probably responsible for stratigraphical gaps in the Upper Silesia and Saar-Lorraine basins. Continuous deposition is observed in the Intra Sudetic and Central and West Bohemian basins. In the Intra Sudetic Basin, the Cantabrian Substage is represented by the coal-bearing (four coal seams) upper part of the Svatoñovice Member and the red coloured lower Jivka Member. The Central and West Bohemia basins had braided fluvial systems depositing thick packages of greyish coalbearing coarse-grained sediment passing upward into reddish sediment with no coals. The available data for the Dobrudzha Coalfield are insufficient for the detailed description of sedimentary environments, but Tenchov (1993) has suggested the deposits show features of fluvio-lacustrine settings with synchronous volcanic activity.

\section{Barruelian Substage ('Stephanian A')}

In the areas covered in this study, deposits of confirmed Barruelian age are known only from intramontane basins, where they represent red-bed deposits of braided types of rivers. In the correlation chart, the Kwaczała Arkose of the Upper Silesia Coal Basin is ascribed to the Barruelian Substage, although in Polish literature it has been determined as Stephanian B in age on the basis of its lithological similarity to the Intra Sudetic's red coloured deposits and the presence of silicified Dadoxylon tree trunks (Rutkowski, 1972). The only known red-bed facies from the Czech Republic are Barruelian in age and not Stephanian B, and thus the stratigraphical break between the coal-bearing succession and the barren-rocks is of shorter range. It has been suggested that the red-bed upper Warwickshire Group in the Pennines Coalfield may be Barruelian in age but there is no biostratigraphical verification for this. 


\section{Stephanian B Substage}

We are treating the 'Stephanian B' here in its traditional sense as represented by the 'Zone de Tronquié' of Carmaux, rather than that represented by the Assise de St Étienne in the St Étienne Basin, which Wagner (1998) has shown to be significantly younger.

In the area covered by this study, Stephanian B deposits are only known from the intramontane basins. In Saar-Lorraine, they appeared after a sedimentary break and a period of erosion with the Holz Conglomerate, the product of a braided river system. After base level rise, more fine-grained material with coal seams was deposited, followed by red-bed facies. In the middle part of the red-beds sequence the zone of Illingen (Reisbach) coals is intercalated. In the Intra Sudetic Basin, the Stephanian B Substage is represented by the uppermost part of a thick fining upward cycle, containing coal seams. The Central and West Bohemia basins are characterized by fining-upwards cycles starting with coarse-grained braided-river deposits, abruptly followed by lacustrine and deltaic deposits, and in turn replaced by fluvial conditions. Those lacustrine deposits are widely spread and can be traced across the whole basin up to the Intra Sudetic Basin, and represent one of the largest Stephanian lakes in Euramerica (Lojka et al, 2009). Such a regional base-level rise allowing lake and lacustrine delta development might also have been responsible for the deposition of the grey zone of the Illingen (Reisbach) coals within the otherwise red-beds succession in the Saar-Lorraine Basin.

\section{Stephanian C-Autunian substages}

The youngest Carboniferous strata of the Saar-Lorraine Basin are separated from older units by a stratigraphical gap, and are represented by grey deposits, mainly sandstones and mudstones with intercalations of fresh-water limestones and tonsteins. There is also a coal seam, which was locally exploited. The same gap is probably present in the Czech intramontane basins, although it has a longer duration here and was related to the Intra Stephanian Phase (Havlena, 1965). In the Central and Western Bohemian Basins the gap is additionally marked by an erosional surface (Skopec et al., 2000) on which a sequence of red-beds has been deposited with frequent carbonate nodules and interbedded by grey deposits, volcanoclastics and lacustrine carbonates. In the Intra Sudetic Basin, after a hiatus of even longer duration, red coloured deposits of a fluvial cycle are present, locally containing a thin coal seam.

\section{Effect of Variscan tectonic phases}

At least five main tectonically-driven stratigraphical gaps or major changes in patterns of deposition can be observed in the analysed basins (Fig. 27).
Erzgebirge Phase

This coincides with the Mississippian-Pennsylvanian boundary. The record of tectonic movement is best expressed in the Upper Silesia Coal Basin, where the gap can be linked with the rebuilding of depositional systems of basin infill. In other areas, such as the Intra Sudetic and Dobrudzha basins, the stratigraphical gap is a little longer. Thereafter, deposition of the coarsest clastic material under alluvial fan conditions occurred (Intra Sudetic). However, in those basins where continuous sedimentation took place through the MississippianPennsylvanian boundary (Pennines, South Wales, Ruhr), the Erzgebirge Phase had little evident effect on patterns of sedimentation, being overprinted by the effects of the midCarboniferous Eustatic Event that resulted in the progressive replacement of marine conditions by deltaic and shallow shelf settings, and the appearance of thin but numerous coal seams and thick sandstone bodies of deltaic origin.

\section{Pre-Leonian Phase}

The effects of the second tectonic event can be seen near the Duckmantian-Bolsovian boundary, and is called here the pre-Leonian Phase. Its effects are clearly visible in the Ruhr, Saar-Lorraine, Central and West Bohemia, Intra Sudetic, Upper Silesia and Dobrudzha basins; it is also weakly expressed in the Lublin-Volhynia Basin. The pre-Leonian Phase in the intramontane basins is marked by the presence of a short stratigraphical gap (Saar-Lorraine, Intra Sudetic and Upper Silesia basins) or the creation of alluvial valleys followed by thick fluvially-originated deposits with coals (Central and West Bohemia). In some basins, strong volcanic activity has been recorded (Ruhr, Saar-Lorraine, Upper Silesia, Central and West Bohemia basins). Moreover, this tectonic episode in the Upper Silesia Coal Basin can be linked with the change in fluvial style from meandering/anastomosing to distal braided, and in the Ruhr Basin with the general change of the depositional systems from paralic to continental. There is no evidence of a stratigraphical gap at this level in the Dobrudzha Coalfield, but there is evidence of two deep erosion events pointing to base-level fluctuations.

\section{Malvernian Phase}

In South Wales, Bristol-Somerset, the Pennines and the North Sea there is a marked change in sedimentation in mid-Bolsovian times; in the former two areas, large quantities of clastic sediment were washed in from the Variscan Mountains to the south, whereas in the Pennines and North Sea there was a marked fall in water tables and the development of red-beds. Based on the British data, Moore \& Blundell (1952) termed this the Malvernian tectonic phase. The effects of this movement are less evident further east. In the Ruhr Basin there is a withdrawal 


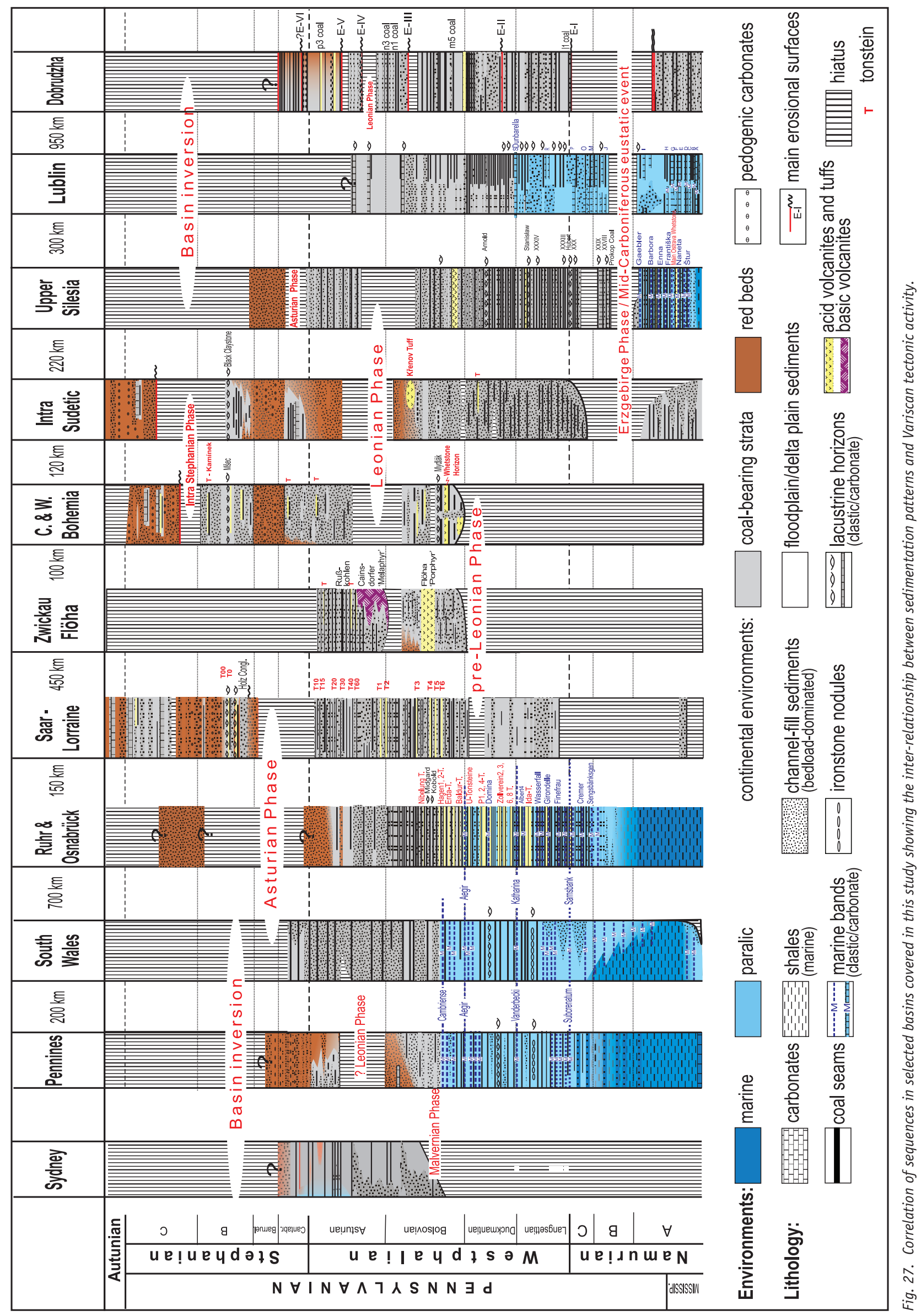


of marine influence, possibly partly resulting from tectonic uplift, but otherwise sedimentation was not significantly affected. There is also a short stratigraphical gap at about this level in the Dobrudzha Coalfield (below the Velkovo Formation) but this may be merely coincidental and not genetically connected.

\section{Leonian Phase}

This had a regional significance. Its effects can be seen in the lower to middle Asturian Substage across central Europe, including the Central and West Bohemian, Intra Sudetic and Upper Silesian basins. On the flanks of the analysed sector of the Variscan Chain (the British basins and Dobrudzha) there is evidence of base-level lowering that can be linked with this episode, manifested as stratigraphical gaps of varying duration and sometimes (as in the Dobrudzha Coalfield) connected with basin-scale erosion. In the Pennine and Intra Sudetic basins, the stratigraphical break was preceded by red-bed facies deposition, whereas in the Ruhr Basin upper delta plain conditions were replaced by purely continental conditions. In the Sydney Coalfield, in contrast, the input of coarse clastic sediment into the basin was reduced and coal-bearing facies become dominant, with some evidence of estuarine conditions in the southeast of the basin.

\section{Asturian Phase}

The last regional-scale tectonic event is associated with the northward advance of the Variscan thrust-fold belt into the foreland basin (e.g. Gayer et al., 1993), which probably culminated in middle - late Cantabrian times. We have followed Stille (1924) and referred to it as the Asturian Phase although we recognise that the classic unconformity in the Asturian foldbelt is probably of somewhat younger, middle Barruelian age (e.g. Wagner \& Winkler-Prins, 1970). It resulted in shortening and overthrusting of older strata across the southern margin of the foreland basin, with displacement in the scale of several tens of kilometres, and up to about $120 \mathrm{~km}$ in the French sector (Raoult \& Meilliez, 1987; Bless et al., 1989). Its most significant effects on sedimentation patterns were in the basins of the Variscan foreland and the associated cratonic areas where it caused basin inversion and the end of Pennsylvanian deposition (in the South Wales, Pennines, North Sea, Limburg, Ruhr and Dobrudzha basins). After a stratigraphical gap in the Upper Silesia Coal Basin, sedimentation was renewed but the youngest unit here is entirely lacking in coals. In the Sydney Coalfield it marks a change to red-bed deposition but evidence as to how long this deposition persisted for is equivocal. The variation in age of the youngest Carboniferous strata in different parts of the Variscan foreland may simply be due to differences in the amount of these strata that have been lost to erosion, but there may also have been differences in the timing of when deposition ceased due to uneven tectionic activity across the area. However, there is no unequivocal biostratigraphical evidence in any of these basins of coal-bearing Carboniferous deposits older than early Cantabrian in age.

In Saar-Lorraine there is a stratigraphical break below the Holz Conglomerate corresponding to the Asturian Phase but deposition resumed in Barruelian times and this included some grey coal-bearing measures. Deposition also ceased in the Zwickau Basin at about this time. In Central and Western Bohemia and the Intra Sudetic Basin, however, deposition continued intermittently through to Autunian times in both grey coal-bearing and red-bed facies. This suggests that development of coal-forming habitats was not exclusively under the control of climate, but local variation in base level was also a major factor, affecting the type of accumulated sediments and the depositional style.

\section{Withdrawal of marine influence}

There was an almost complete disappearance of marine faunas across the area investigated during Bolsovian times. The only notable exception is the report of late Asturian and early Cantabrian estuarine microfaunas in the Sydney Coalfield, and the Osnabrück Coalfield near the Ruhr. Two alternative and most probably interconnected mechanisms are possible to explain this withdrawal of marine influence. On the one hand, the ice-sheet of Gondwana stored vast quantities of oceanic water, causing a global oceanic regression. On the other hand, the northward tectonic invasion of Variscan overthrust-piles onto Laurussia caused sediment supply to overtake accommodation space. The local (basin-scale) variation in the ratio of available accommodation space to deposition created differences between particular basins. However, a detailed analysis of this interaction and its effects on marine influence is beyond the scope of this report.

\section{Synthesis}

Although the various sedimentary basins examined in this study occupied different geotectonic and palaeogeographical positions, with more or less independent tectono-sedimentary histories, it is possible to find some features which all these basins have in common.

Palaeogeographically the basins can be subdivided into those located along the coastal lowlands of the Variscan foreland and intramontane basins. The former occupied vast areas of lowlands between the Variscan foreland along the northern edge of the Rheno-Hercynian nappes and the southern part of the pre-Variscan craton of Laurussia. The total area covered by these lowlands is estimated to have been upto nearly $1,500 \times 10^{2} \mathrm{~km}^{2}$. All these basins display a general shallowing trend from purely marine or shallow-marine strata, through mixed (paralic) continental and shallow marine 
sediments, to dominantly fluvial strata or alluvial deposits of a piedmont area (Dreesen et al., 1995; Opluštil \& Cleal, 2007). However, the timing of these major changes in sedimentary environments was strongly diachronous across this vast area (Fig. 27). The onset of coal-bearing deposition started with the establishment of 'paralic' conditions, i.e. dominantly continental deposition interrupted with occasional marine ingressions. Such conditions were first established in the Upper Silesian Coal Basin in early Namurian (Pendleian) times and to a lesser extent also in the Lublin Basin. Further west this transition took place much later, in middle to late Namurian times in the Ruhr, northern France and Campine-Limburg basins. It started even later in the British Isles where, except in Scotland, the onset of coal-bearing deposition dates to early Langsettian times.

The withdrawal of marine influence was also diachronous across the area: the youngest Carboniferous marine deposits in Upper Silesia are Alportian in age, in Lublin earliest Duckmantian, in the Ruhr earliest Bolsovian and in Britain mid-Bolsovian. As well as lacking marine bands, this continental part of the coalbearing sequences of the Variscan foreland is dominated by coarse-grained fluvial sediments of meandering to braided rivers. However, this withdrawal of marine influence is not correlated with any significant reduction in coal swamp development, which continued in many areas across the foreland until Asturian or even early Cantabrian times. The cessation of coal swamp development in fact occurred earliest in some of the more westerly parts of the foreland such as the Pennines and southern North Sea, where coal-barren fluvial red-beds appear in early Bolsovian times (in some places even earlier). But this decline in the coal swamps was uneven, with coal swamps continuing in southern Britain until Cantabrian times, suggesting that it was not a response to regional- or global-scale influences such as falling sea levels or climate change, but was due to more localised effects such as changing substrate and/or drainage conditions.

The intramontane basins usually represent small late orogenic or early post-orogenic basins, filled with non-folded fluvio-lacustrine strata. The onset of deposition in these continental basins is highly variable. In the Intra Sudetic Basin, for instance, coal-bearing deposition had started already during late Mississippian times, whereas in Central Bohemia it did not start until late Duckmantian times. They represent relicts of fluvial valley-fills connected with the coastal lowlands via rivers which drained the Variscan Mountains (e.g. Opluštil, 2005; Schneider et al., 1998). They commonly have several hiatuses related to the various tectonic phases. Coal formation continued intermittently in the intra-montane basins through Stephanian times, in contrast to the foreland basins where only coal-barren red-beds were being laid down.

\section{Climatic signals}

Climatic signals in the sedimentary record of these basins are provided by the distribution of red coal-barren and grey coalbearing strata, the character of soils and coal seams. The oldest Pennsylvanian red-beds accompanied by a decrease in the number and thickness of coal seams are in the Langsettian Substage of the Pennines, but became more widespread in that basin in the Bolsovian Substage (the Etruria Fm). This formation has a strong diachronous base and is coeval with grey coalbearing strata elsewhere in the basin. Based on palaeosol geochemistry and mineralogy, these red-beds have been interpreted as being the result of water table fluctuations rather than climatic changes (Besly \& Turner, 1983; Besly, 1987; Besly \& Fielding, 1989). There are no lateral (time) equivalents of these red-beds in other parts of the Variscan foreland, nor in most of the continental basins; the only notable exception is in the Intra Sudetic Basin, where Bolsovian sediments in the upper part of the Žaclér Formation (Petrovice Member) also represent fluvial red-beds with few coals.

Red-beds became much more widespread in early Stephanian (Barruelian) times, when prominent basin-wide red-beds, several hundred metres thick, occur in the basins of the Bohemian Massif (Intra Sudetic, Central and Western Bohemia, Upper Silesian basins). They are also common in the upper Stephanian parts of these basins, whereas middle Stephanian strata are locally coal-bearing (Fig. 27). Although most red-beds occur stratigraphically in the Stephanian parts of basin fills, locally they can appear at any level from the Bolsovian Substage upwards. This indicates that their formation was controlled not only by climatic change but also some local (? tectonic) factors.

\section{Palynology (J. Bek)}

The palynological research in this project has concentrated on two main aspects.

- Biostratigraphy. The stratigraphically most important spore and pollen taxa in the various basins were studied: the smallest monoletes (excluding Thymospora), Thymospora, Florinites, Endosporites, Triquitrites, Cadiospora, Westphalensisporites, Latensina, Schopfites, Dictyotriletes bireticulatus, monosaccate pollen, bisaccate pollen and striate pollen.

- Palaeoecology. The reconstruction of plant assemblages and their environments was based on a comparison of the spore and pollen taxa that are ecologically significant, with a special focus on the Westphalian-Stephanian boundary. This has drawn especially on our knowledge of in situ spores isolated directly from the reproductive organs of plants. Ecologically important spore taxa are Lycospora, Vestispora, Endosporites, Densosporites, Cirratriradites, Crassispora, Cadiospora, Florinites, Cordaitina, bisaccate pollen, taeniate 
bisaccate pollen, and monoletes $\leqslant 40 \mu \mathrm{m}$ in diameter. The main ecologically significant taxa represent the main plant groups, i.e. arborescent (lycospores, Crassispora, Cadiospora), sub-arborescent (Densosporites and Endosporites) and herbaceous lycopsids (Cirratriradites), sphenophylls (vestispores), ferns (smallest monoletes), cordaites (Florinites and some monosaccates) and conifers (probably some bisaccates). We still have no idea about the affinity of some of the other ecologically important taxa, i.e. most of bisaccate and striate pollen. Sphenophytes are represented by calamospores, which are long-ranging spores and globally wide-spread, and have no stratigraphical or ecological significance.

Palynological data derived from clastic sediments and from coal seams were kept separate. Only the Netherlands and Canada provided data from clastics; the palynological information from other countries are from coal seams.

The palynological record includes spores and pollen of the selected most important taxa, less than $200 \mu \mathrm{m}$ in diameter (the formal artificial limit between mio- and megaspores). This is why the general picture of the spore and plant assemblages lacks any mention of representatives of pteridosperms. Prepollen of the Schopfipollenites-type indicate the occurrence of some medullosalean pteridosperms but they are rarely recorded in dispersed spore assemblages as their relatively large diameter (more than $200 \mu \mathrm{m}$ ) means that they are lost during sieving during most palynological preparations. Consequently, the estimation of the composition of plant assemblages based on the palynological record is reconstructed without pteridosperms, which are masked by spores and pollen of other plants groups.

Palynological data have been obtained from the following basins: Dobrudzha Basin, Bulgaria (provided by T. Dimitrova), Upper Silesian and Lublin basins, Poland (M. OliwkiewiczMiklasinska), Intra Sudetic, Kladno-Rakovník, Plzeň and Radnice basins, the Czech Republic (J. Bek, J. Drábková), Ruhr and Saar basins, Germany (Ch. Hartkopf-Fröder), the Netherlands (T. van Hoof, 0. Abbink), UK (T. Dimitrova, D. McLean), the Sydney Coalfield, Canada (T. Dimitrova) and the North Sea area (D. McLean). Spores were usually macerated using nitric acid or Schultze's solution (coal samples), neutralised by hydrate of sodium or potassium hydroxide, and washed several times in distilled water. Spores isolated from clastics were usually macerated using hydrofluoric acid. Spores are compared according to the system of classification of dispersed spores suggested by Potonié \& Kremp (1954, 1955), Dettmann (1963) and Smith \& Butterworth (1967).

\section{Dobrudzha Basin}

The following account deals with the late Westphalian palynofloras from coals in boreholes P-172 and borehole P-191 (Dimitrova \& Cleal, 2007). The boreholes P-172 and P-191 sequences belong to the Gurkovo Formation (Westphalian D / Cantabrian), whilst the borehole $\mathrm{P}-177$ sequence belongs to the Krupen and upper Makedonka Formations (Bolsovian). The coals from these formations are economically the most important of the Dobrudzha Basin. The microfloristic assemblages reflect more swamped and drier areas within the coal swamps, with three marked changes in their composition having been identified, at coals m5, p1 and p3.

\section{Upper Silesian Basin}

The Orzesze Beds of the Mudstones Series represent the local palynozone Eg (Endosporites globiformis) of Duckmantian age. Based on Jachowicz (1972) and Jachowicz \& Dybova-Jachowicz (1983), the palynology of the coals on average consisted of 1530\% Flemingitaceae/Lepidocarpaceae lycopsids (Lycospora and Densosporites), 15\% Sigillariostrobaceae lycopsids (Crassispora) and 2-5\% marattialean ferns (Punctatosporites).

The bottom part of the Eaziska Beds represents the local palynozone Vm (Vestispora magna) and is also of Duckmantian age. These local palynozones distinguished within the Duckmantian deposits of Upper Silesia correspond to the standard Zone NJ of Clayton et al. (1977). The remaining part of Eaziska Beds up to coal seam 119 represents local palynozone Tsl (Torispora securis-laevigata) of Bolsovian age. The lower part of this zone is determined by the appearance of species such as Torispora securis, T. laevigata, Vestispora fenestrata, Punctatosporites granifer. Based on Jachowicz (1972) and Jachowicz \& Dybova-Jachowicz (1983), the palynology of the coals on average through the formation consisted of $45-60 \%$ Flemingitaceae/Lepidocarpaceae lycopsids (Lycospora and Densosporites), $<5 \%$ Sigillariostrobaceae lycopsids (Crassispora) and $30-45 \%$ marattialean ferns (Punctatosporites, Thymospora, Torispora). The palynology therefore suggests an increase in both peat-substrate lycopsids and the marattialean ferns, perhaps indicating an overall reduction in habitat diversity in the wetlands.

The Libiąż Beds above coal seam 119 represents the local palynozone To (Thymospora obscura) of Asturian age, with characteristic taxa Westphalensisporites irregularis, Spinosporites spinosus, Speciososporites minor and Punctatosporites oculus. Based on Jachowicz (1972) and Jachowicz \& Dybova-Jachowicz (1983), the palynology of the coals on average through the formation consisted of up to $90 \%$ marattialean ferns (Punctatosporites, Thymospora, Torispora) and a consequential much reduced lycopsid component.

Kmiecik in Zdanowski \& Żakowa (1995) suggested that there is a stratigraphical gap at the Bolsovian/Asturian boundary and this was confirmed by macrofloral research (Kotasowa in Zdanowski \& Żakowa, 1995). In the local palynozone Tsl, Kmiecik recorded the rare occurrence of upper Westphalian taxa, while the macroflora from the Libiąż Beds has the character of the Lobatopteris vestita Zone of late Asturian age. 
The age of the Kwaczała Arkose cannot be determined by palynology. However, the macrofloras suggest that it is Stephanian B in age (Kotasowa in Zdanowski \& Żakowa, 1995) based on a comparison with similar deposits in the Sudetes (Žaltman Arkose of the Lower Silesian Coal Basin).

\section{Lublin Basin}

Duckmantian deposits represents the local palynozones Eg (Endosporites globiformis), Ts (Triquitrites sculptilis) and Vm (Vestispora magna), which correspond to the standard palynozone NJ of Clayton et al. (1977). Bolsovian deposits belong to the local palynozone $\mathrm{Vf}$ (Vestispora fenestrata), which corresponds to the standard palynozone SL. The lower part of this palynozone was distinguished in a few boreholes in the southern part of Lublin Basin, while the upper boundary of Vf palynozone was established only in Piaski IG 2 borehole. The lower boundary of the Vf local palynozone is defined by the appearance of Punctatosporites granifer and the rare occurrence of Torispora.

Asturian deposits were identified only in the Pisaki IG 2 borehole. These deposits represent the local palynozone Wi (Westphalensisporites irregularis) with the maximum extent of the index species, the appearance of Thymospora, and single specimens of Lunbladispora gigantea and Schopfites sp. A characteristic feature of the Wi palynozone is a qualitative increase in Torispora and Triquitrites. The location of the upper boundary of the Wi palynozone is unknown due to postCarboniferous erosion.

\section{Central and Western Bohemian and Intra Sudetic basins}

The stratigraphical interval of the project is represented by the Žacléř (Lampertice, Prkenný Důl-Žd'árky and Petrovice members) and Odolov formations in the Intra Sudetic Basin and the Kladno Formation (Radnice and Nýřany members) of the Kladno-Rakovník, Plžen and Radnice basins. Palynological data from the Intra Sudetic Basin are summarised based on the research of Kalibová-Kaiserová, Valterová, Bek and Drábková. Czech palynologists have not established a Carboniferous palynozonation for the Czech Republic and therefore a comparison with the palynozonation of Western Europe is difficult.

\section{Ruhr and Saar-Lorraine basins}

In the Ruhr Basin, palyno-stratigraphical research started with the benchmark contributions by Potonié in the 1930s. Seven miospore zones and several subzones proposed by Potonié range from the Lower Bochum Formation (upper Langsettian) to the Lembeck Formation (upper Bolsovian).

The Pennsylvanian sequence in the Saar-Nahe basin provides the most detailed information on the miospore distribution in an intramontane basin in Germany, with five miospore zones and seven subzones. The lowermost one has been dated as late Duckmantian in age, the uppermost one as Stephanian C in age. However, the strata of latest Asturian, Cantabrian and early Barruelian age are missing because of a hiatus below the unconformity at the base of the Holz Conglomerate. Palynological research was done mainly by Ibrahim, Loose, Potonié, Potonié \& Kremp, Bharadwaj, Grebe and Döring.

\section{Limburg Basin}

The type section of the Kemperkoul Member (Bolsovian) of the Maurits Formation (late Duckmantian - Bolsovian) is located in the well Kemperkoul-1 in the south-eastern part of the Campine basin in the former mining district of Limburg. The stratigraphical control is based on marine band stratigraphy and palaeobotany (Van Amerom \& Pagnier, 1990). Because of this age-control, the quantitative distribution of sporomorph taxa through the upper Bolsovian to upper Duckmantian of this well was used as a reference. All samples of this well were derived from lithofacies representing mainly relatively well-oxygenated lake deposits and just a few marine horizons (Abbink, 2003; Van Amerom \& Pagnier, 1990). The palynological data from these settings should therefore be interpreted as a regional signal in contrast to the local signal derived from coal seams.

Because Asturian to Stephanian deposits are not present in the Limburg area, the reference well for the quantitative distribution of sporomorph taxa during the Asturian to Stephanian interval was chosen to be the De Lutte- 6 well on the fringe of the Ems low basin. Samples were taken from shales and siltstones mainly representing floodplain deposits and soils (Van der Zwan et al., 1993). Three intervals with distinct palynofloras were recognized in this well, of which the second is outstanding as it represents the Itterbeck horizon, a seat-earth with Stigmaria root-systems which is supposed to represent the incursion phase postulated by M.A. Butterworth (as reported by Van der Zwan et al., 1993). A discrepancy between the palynological and palaeobotanical age-interpretation existed as the third interval in this formation represented a relative dry palynoflora with dominating elements Potonieisporites spp., Monosaccates, Cordaitina spp., Illinites complex, Bisaccate taeniate pollen and Endosporites globiformis. This flora is comparable to Stephanian palynofloras, whereas the palaeobotanical interpretation suggested an Asturian association (Van Amerom, 1996). This controversy has recently been resolved by a re-investigation of both the palaeobotany and palynology, suggesting a Stephanian age for these deposits (Van Hoof et al., 2007; Van Waveren et al., 2008).

\section{Southern North Sea Basin}

All sections and material from the southern North Sea are provided by oil and gas exploration and development wells. This means that most sections are only represented by wireline 
electric logs and ditch cuttings material, and that palynology represents the only consistently applicable biostratigraphical methodology (McLean et al., 2005). However, there are significant numbers of continuously cored sections which can provide a complete coverage of the mid Langsettian to early Bolsovian succession. All released cored sections from the UK sector are available for inspection and palaeontological sampling. Core recovery from the higher parts of the sections is much less complete.

The Langsettian to Bolsovian coal measures facies are equivalent to the Pennine Coal Measures Group of onshore UK (Waters et al., 2007) and have been calibrated throughout by miospore biozones (e.g. McLean et al., 2004). The Bolsovian and Asturian red-bed sequences are equivalent to the Warwickshire Group of onshore UK (Waters et al., 2007). They provide some limited miospore recovery, while the Asturian coal measures of the Brig and Boulton formations provide good miospore recovery.

Palynological information from the Germany sector of the North Sea is provided mainly by Lund (2001).

\section{British Coalfields}

Palynological data are summarised mainly in Smith \& Butterworth (1967). Smith \& Butterworth (1967) suggested a palynozonation with eleven palynozones. Palynozones V-XI cover the stratigraphical interval of the project.

\section{Comments on the characteristics of the palynofloras}

The reported stratigraphical ranges of 15 major spore and pollen types across the study area are shown in Figs 28-29. We know the parent plants of only nine of these 15 spore taxa (Endosporites, Triquitrites, Cadiospora, Thymospora, Vestispora, Dictyotriletes bireticulatus, Florinites, the smallest and bigger monoletes). The following are only brief synoptic remarks on their distributions.

- Latensina. The stratigraphical range of Latensina is identical in Bulgaria, Czech Republic and the North Sea area where it is from the Bolsovian to the Cantabrian. Latensina is recorded from the Asturian to Cantabrian substages in UK and in the upper part of the Asturian Substage in the Upper Silesian Basin. Interestingly, Latensina has never been recorded from Lublin, the Ruhr, Saar-Lorraine, the Netherlands or Canada. We have no idea about the parent plants that produced Latensina and therefore it is hard to interpret the ecological reasons for this uneven distribution. It is nevertheless evident that Latensina is an important spore taxon characteristic of younger Westphalian and Stephanian strata.

- Endosporites. The stratigraphical ranges of Endosporites are not identical in all countries. The most abundant species is Endosporites globiformis. Endosporites is a stratigraphically and also ecologically significant taxon. These spores were produced by several species of genera of the Polysporia/ Chaloneria group of sub-arborescent lycopsids. Some species (e.g. Endosporites zonalis) are typical for Duckmantian and Bolsovian strata, but others (e.g. Endosporites globiformis) continue through to the Asturian and Cantabrian substages, which corresponds to the distribution of the parent plants, species of the lycopsid genus Polysporia.

- Westphalensisporites. The occurrence and stratigraphical ranges of Westphalensisporites are different. The most typical is its record within Bolsovian and Asturian strata, but sometimes it occurs in the Duckmantian (Intra Sudetic Basin, Czech Republic and North Sea area) and the Cantabrian (UK). It is not certain what plants produced Westphalensisporites and so its ecological significance is unknown.

- Schopfites. Schopfites ranges from the Bolsovian to the Cantabrian. Its first occurrence is within the Bolsovian but the most abundant and most typical is for the Asturian. Schopfites has never been recorded in the Pennsylvanian of the Czech Republic. It is not known what plants produced this type of spore.

- Triquitrites. This genus, which usually does not occur in large numbers, has a stratigraphical range from the Duckmantian to the Cantabrian. It seems that Triquitrites is stratigraphically not very important. The only known record of in situ Triquitrites is from schizeacean ferns.

- Vestispora. Vestispores are stratigraphically very important. Generally their stratigraphical range is from the Duckmantian to the Cantabrian, but particular species are characteristic for different formations and members. The latest occurrence of vestispores is described from the Cantabrian of UK but their most typical occurrence is in Duckmantian, Bolsovian and Asturian strata. Vestispores were produced mainly by sphenophylls (which are also very good biostratigraphical markers) but some of them (Vestispora laevigata-type) were produced by noeggerathialean plants of the Discinites-type.

- Dictyotriletes bireticulatus. This species is especially typical for the Duckmantian and Bolsovian; exceptional is its latest records in the Asturian of Poland and the Cantabrian of the Intra Sudetic Basin. Generally it represents a spore type typical for lower Westphalian strata of Langsettian and Duckmantian age. Scott et al. (1985) published the occurrence of this type of the spore from an isolated sporangium with a lateral annulus resembling some botryopterids.

- Florinites. This is the most abundant type of pollen in these assemblages. Its general range is from the Duckmantian to Cantabrian, and is more important ecologically than stratigraphically. We supposed that Florinites pollen were produced mainly by cordaitalean plants.

- Cadiospora. The range of this genus starts within the Bolsovian but most typical is found in stratigraphically younger strata of Asturian and Cantabrian age. The parent 

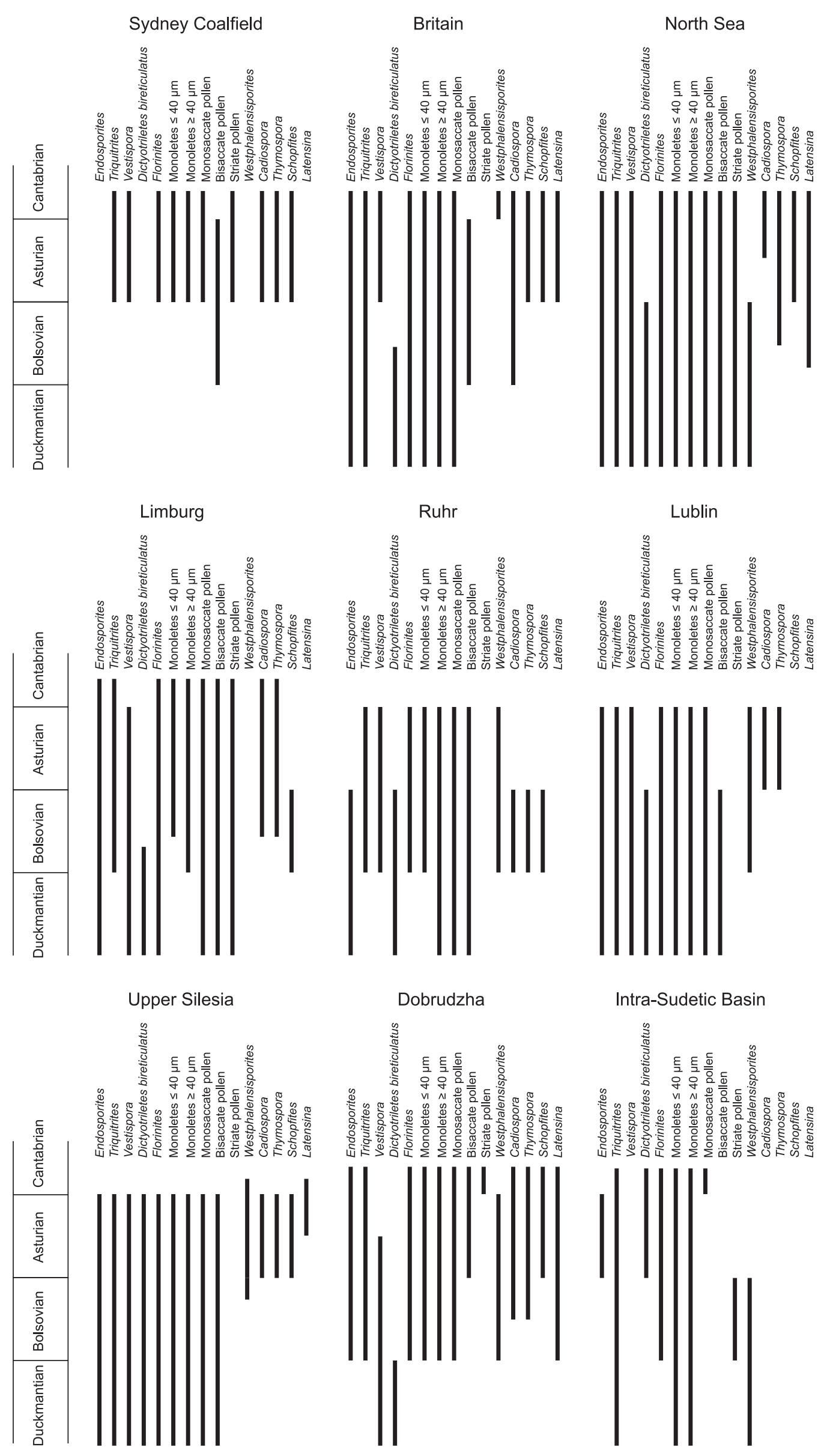

Fig. 28. The stratigraphical ranges of 15 selected spore and pollen types from the various basins studied in this project. See text for sources of data. 


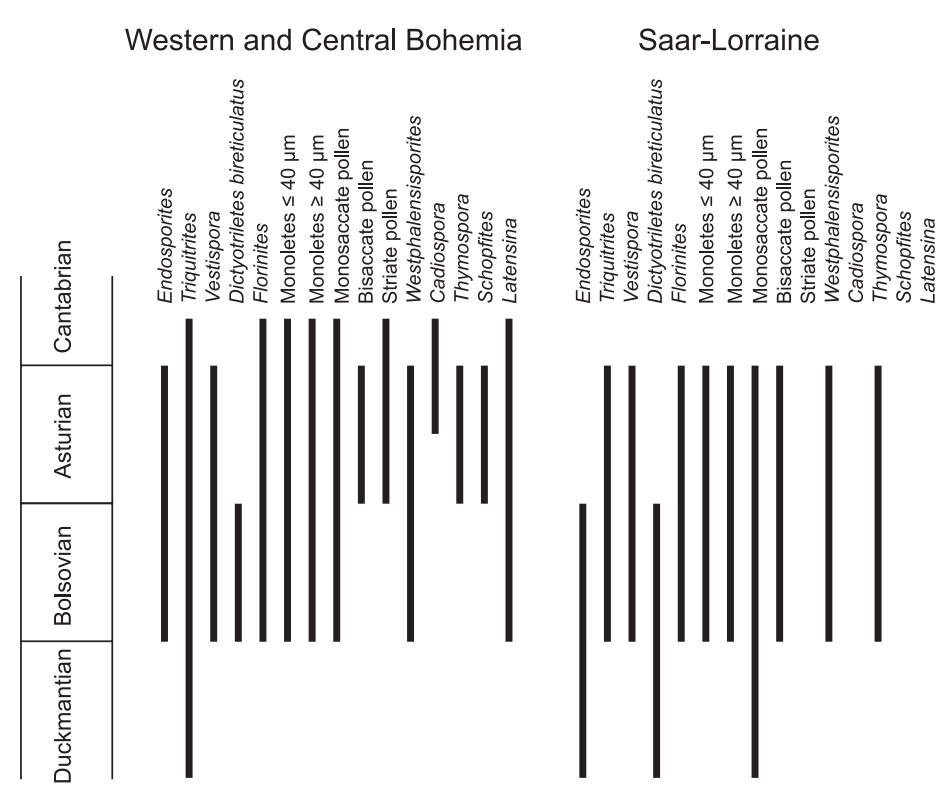

Fig. 29. The stratigraphical ranges of 15 selected spore and pollen types from the various basins studied in this project. See text for sources of data.

plants which produced Cadiospora miospores were a particular type of sigillarian plants (unpublished work). Cadiospora is not a typical member of wet environment palynofloras and its occurrence is more typical for relatively drier periods, especially of Stephanian age. Its occurrence, which is more characteristic for Stephanian strata, corresponds with records of its parent plants, a group of sigillarians which survived the extinction of arborescent lycopsids at the Moscovian-Kasimovian boundary.

- Thymospora. This genus was produced by certain marattialean pecopterids. It first appears in the Bolsovian of Germany, the Netherlands and the North Sea area, but is more typical for stratigraphically younger strata of the Asturian and mainly Cantabrian age.

- Monoletes $(\leqslant 40 \mu \mathrm{m})$. This group of the smallest monoletes includes Laevigatosporites minimus, L. perminutus, Latosporites minutus, Torispora and all species of Punctatosporites. Generally they are more typical for stratigraphically younger strata of Asturian and Cantabrian age, and reach their maximum within the Stephanian Stage. All of these smallest monoletes are of marattialean origin.

- Monoletes $(\geqslant 40 \mu \mathrm{m}$ ). This group includes all species of Laevigatosporites and Latosporites (excluded forms smaller than $40 \mu \mathrm{m}$ ). Their parent plants were certain sphenophylls, and are ecologically rather than stratigraphically important.

- Monosaccate pollen. The group of monosaccates belong to long-ranging pollen, found in strata of Duckmantian to Cantabrian age, and have a greater ecological than stratigraphical significance. This group usually consists of genera Wilsonites, Potonieisporites and some others.

- Bisaccate pollen. Most bisaccate pollen are typical for strata of Westphalian and mainly Cantabrian age, although in some countries they occur in strata as early as Duckmantian in age. Bisaccate pollen usually consists of the genera Pityosporites, Disaccites, Illinites and some others.
- Striate pollen. Striate pollen usually occur in the Asturian and Cantabrian, but can also occur as low as the Duckmantian of the Netherlands and the North Sea area. Striate pollen consists of the genera Vittatina and Striatodiplopinites.

Most of the Westphalian spore assemblages from coal seams are typified by a prevalence of lycospores (produced by arborescent lycopsids of the Lepidodendron- and Lepidophloiostype) with occasional dominance or subdominance of densospores (produced by sub-arborescent lycopsids of the Omphalophloios-type). Stephanian spore assemblages from coals in contrast tend to be dominated by the smallest monoletes, and have a higher percentage of monosaccate, bisaccate and striate pollen. Also more common in these Stephanian palynofloras are Cadiospora and Latensina. This all indicates a change to vegetation dominated by marattialeans, with a common occurrence of cordaites, conifers and one group of Sigillaria.

The spore assemblages from clastic deposits (from the Netherlands and Canada) show only minor qualitative differences from those of the coal seams. Some important taxa (e.g. vestispores and Westphalensisporites) have comparable stratigraphical ranges. The main difference is that most of pollen (monosaccate, bisaccate and striate) occur earlier in clastic sediments that in coal seams. This suggests that their producers (i.e. probably some types of conifers and cordaites) were more typical for the environment where the clastics were being deposited. Such pollen is also found in coal seams but their producers were probably never important producers of biomass in the swamps. Such pollen tends to have a morphology that is better adapted to wind transport, in contrast to spores which were usually transported by the water. More probable, therefore, most of the parent plants of this pollen grew more or less far from the environment typical for origin of coal seams. 


\section{Westphalian-Stephanian boundary}

The Westphalian-Stephanian boundary is not developed in all countries studied but, where it is, the Duckmantian-Cantabrian spore assemblages have many features in common. Few of the selected spore taxa occur only in the Westphalian or only in the Stephanian in any of the countries. The composition of the palynofloras changes step by step from the Bolsovian, through the Asturian to the Cantabrian, and there is no evidence of a marked biological event at the Westphalian-Stephanian boundary. The observed gradual palynological changes at the boundary are indicative of ecological and not evolutionary trends.

- Dobrudzha. The end of the Asturian is characterized by the last occurrences of Westphalensisporites and Schopfites. Another important genus, Vestispora, occurs for the last time within lower Asturian strata. Striate pollen appears in the Cantabrian. The appearance of Thymospora and Cadiospora in Asturian strata here indicates a very late Asturian age.

- Poland. The Asturian-Cantabrian boundary appears not to be preserved. The characters of the assemblages in both Upper Silesia and Lublin basins are comparable. Some taxa appear for the first time within the upper part of the Carboniferous succession here, including Cadiospora and Thymospora, which are mainly characteristic for the Stephanian Stage, although also typical for uppermost Asturian.

- Czech Republic. The Westphalian-Stephanian boundary in central and western Bohemia is characterised by the last occurrences of vestispores, Westphalensisporites and Endosporites in the Asturian. The genus Cadiospora appears rarely in the upper Asturian, but is more common and typical for Cantabrian strata.

- Germany. Cantabrian strata are not preserved in the Ruhr or Saarland. The genera Schopfites, Thymospora and Cadiospora, which are more typical for Stephanian assemblages, occur for the first time in the Bolsovian or Asturian.

- The Netherlands. A situation similar to that seen in Germany also occurs in the Netherlands. The only important palynological event is probably the last occurrence of vestispores in the Asturian. Cadiospora and Thymospora make their first appearances in Bolsovian strata.

- North Sea. It seems that it is not possible to recognise the Westphalian-Stephanian boundary palynologically in the North Sea area because several taxa occur in Asturian as well as in Cantabrian strata. Some taxa including Latensina, Thymospora and Cadiospora occur in the upper Bolsovian or Asturian for the first time.

- British Isles. Important here is the first occurrence of Westphalensisporites in the Cantabrian, and the appearances of Latensina, Cadiospora, Schopfites, Thymospora and bisaccate pollen within Bolsovian and Asturian strata.
- Canada. Asturian and Cantabrian palynological assemblages are uniform and similar to each other here. All stratigraphically important taxa occur together in both Asturian and Cantabrian assemblages.

The 'translation' of the palynological record into the plant record lacks representatives of pteridosperms. Pteridosperm prepollen of the Schopfipollenites-type indicating the occurrence of some medullosalean pteridosperms are of relatively large diameter (more than $200 \mu \mathrm{m}$ ) and tend to be lost during sieving in palynological laboratories. Consequently, the composition of plant assemblages estimated from the palynological record is without pteridosperms, which are masked by spores and pollen of plants of other groups.

Generally there are some qualitative as well as quantitative changes. Spores of lycopsids generally declined from the Westphalian to the Stephanian, especially arborescent forms producing Lycospora and Cappasporites that were of the Lepidodendron- and Lepidophloios-type. These trees, which preferred wetter environments, are generally less common and only some of them survived to Stephanian times. Exceptions among arborescent lycopsids are sigillarians, which produced spores of the Crassispora and Cadiospora-types, and which occur in Westphalian as well as Stephanian assemblages. Cadiospora is especially typical mainly for strata of Stephanian age, although they first appear in the Bolsovian Substage. However, their Bolsovian and Asturian records are sporadic and not as common as in Stephanian assemblages.

Representatives of sub-arborescent lycopsids produced densospores and spores of the Endosporites and Spencerisporites-types. Producers of these spores (fossil plant genera Omphalophloios, Polysporia/Chaloneria and Spencerites) survived the extinction of the arborescent lycopsid forms and their remains are found in Stephanian as well as Westphalian strata, although their records in the upper Westphalian are more common. Interesting is that some Polysporia/Chaloneria species grew in Westphalian times based on the palynological record and some others in Stephanian times. Herbaceous lycopsids of the Selaginella-type which produced miospores of the Cirratriradites and Lundbladispora-types are typical mainly for Westphalian strata.

It is possible to subdivide sphenopsid spores and plants into two main groups. The first group of spores is represented by calamospores, which are long-ranging spores with a globally widespread distribution. Calamospora-producers were mainly species of the genus Calamites. The second group consists of sphenophyllalean spores, produced by plants with reproductive organs like Bowmanites and Sentisporites/Peltastrobus, including especially Vestispora, Pteroretis, Dictyotriletes muricatus, Columinisporites and Punctatisporites obesus-types. Both the spores in this second group and their parent plants are good biostratigraphical markers. Most of the sphenophylls are typical for the Westphalian (Vestispora, Dictyotriletes muricatus, 
Pteroretis and Punctatisporites obesus-producers). Only a few sphenophylls survived through to the Stephanian or even Permian, and these produced laevigate monoletes of the Laevigatosporites and Latosporites-types (more than $40 \mu \mathrm{m}$ in diameter) and striate monoletes of the Columinisporites-type.

Some spores produced by various types of ferns are longranging, such as Granulatisporites, Leiotriletes, Apiculatisporis, Punctatisporites, Cyclogranisporites and Raistrickia. Some others, especially those produced by certain marattialeans, occur within Bolsovian and Asturian strata but their maximum occurrence is typically in the Stephanian Stage where they are often dominant or subdominant. Typical representatives of these marattialeans are the smallest monoletes Punctatosporites, Torispora, Thymospora, Speciososporites, and the smallest species of genera Laevigatosporites and Latosporites.

The number of monosaccate pollen of the Florinites-type produced by cordaites increases towards the Stephanian. Florinites occurs regularly in Westphalian strata but its maximum is within the Stephanian. Monosaccate pollen consists of several genera.

Some bisaccate and striates pollen were probably produced by conifers and their occurrences are more typical for Stephanian strata, although their first occurrences are within the upper Westphalian.

In conclusion, the Westphalian plant assemblages (without pteridosperms because usually we have no palynological evidence about them) were characterized by a prevalence of arborescent and sub-arborescent lycopsids, and the common occurrence of sigillarians, calamites, sphenophylls and some ferns. Cordaites and conifers also occurred but in low numbers. Stephanian plant assemblages, in contrast, probably were dominated by marattialeans and some other types of ferns, with sub-dominant conifers and cordaites. Some new species of sigillarians and sub-arborescent lycopsids (Polysporia-type) occurred in high numbers. This probably does not reflect evolutionary change, but was probably influenced by different ecological conditions; a change to a drier climate is in particular indicated due to an increased representation of cordaites and conifers in the Stephanian, whose spores occurred in higher percentages in clastics of Westphalian age.

\section{Macrofloras}

\section{Lycopsids (B.A. Thomas)}

The vegetation of the Pennsylvanian-aged palaeotropical swamps was dominated by plants related to Recent clubmosses and quillworts (lycopsids). In contrast to the living herbaceous lycopsids, however, many were large trees up to 50 $\mathrm{m}$ tall. Their stems, leaves and reproductive organs are often common fossils in Westphalian roof-shale and their rooting organs are found in the seat earths associated with coal seams. Because the different parts of the arborescent lycopsids are often found separated in the fossil record and we still do not have a clear picture of which parts belonged together, they tend to be assigned to separate fossil-taxa.

The problems with using fossil lycopsids for stratigraphical comparisons can be identified as:

1. Identification - What is the fossil?

2. Nomenclature - What name should it have? This is achieved through:
a) Recognition of diagnostic features
b) Comparison with previously named specimens
c) Comparison with type specimens
d) Interpretation of synonymies

3. What is the locality and stratigraphical horizon of the specimen?

4. What are the localities and stratigraphical horizons of previously published records?

5. Are there any rare genera that might overemphasise differences between coalfields?

The study of these dispersed organs over many years has shown that the characters used in species diagnoses, or descriptions of specimens are not equally useful, while some are even next to useless for identification. The useful characters in identifying species in the commonest genera of lycopsids are shown in the following Table 4.

Based on the most useful criteria, species lists were compiled from thirteen coalfields using reliable published information and the author's (Thomas's) records. Figured specimens were all studied and sometimes re-identified to ensure a consistency in taxonomy. Separate lists were compiled for the Bolsovian, lower Asturian and upper Asturian/lower Cantabrian (Tables 5-6). The following published sources were used in this:

- Nova Scotia: Bell (1938, 1940), Calder et al. (1996), Thomas \& Tenchov (2004), Zodrow \& Cleal (1985) and Zodrow \& McCandlish (1980).

- Southern Britain: Arber (1912), Besly \& Cleal (1997), Cleal (1978, 1984b, 1991a, 1997), Cleal \& Thomas (1992), Dix (1931), Thomas (1978), Thomas \& Cleal (1994), Thomas \& Tenchov (2004) and Wagner \& Spinner (1972).

- Pennines: Arber $(1913,1916)$, Cleal (2005), Kidston et al. (1917) and Thomas (1978).

- Iberia: Talens \& Wagner (1995), Wagner \& Lemos de Sousa (1983) and Wagner \& Winkler Prins (1979).

- Nord-Pas-de-Calais: Corsin (1932) and Laveine (1987).

- Limburg \& Ruhr coalfields: Van Amerom (1996) and Josten \& Laveine (1984).

- Saar Lorraine: Grauvogel-Stamm et al. (1992) and Laveine (1989).

- Poland: Kotasowa \& Migier in Zdanowski \& Żakowa (1995).

- Austria: Fritz \& Boersma (1983a, 1983b).

- Bohemia: Bek (1995), Bek \& Opluštil $(1988,2004)$, Bek et al. (2001) and Thomas (2005). 
Table 4. The useful characters in identifying species in the commonest genera of lycopsids.

\begin{tabular}{|c|c|c|c|c|c|}
\hline \multirow[t]{2}{*}{ Family } & \multirow[t]{2}{*}{ Lycopsid organ } & \multicolumn{4}{|l|}{ Usefulness of characters } \\
\hline & & Good & Sometimes useful & Not always reliable & Useless \\
\hline Flemingitaceae and & Stems (cushion & Shape & Size & Cushion size & \\
\hline \multirow[t]{13}{*}{ Lepidocarpaceae } & characters) & Bulging nature of cushions & Joining of cushions & Separation of cushions & \\
\hline & & Shape and position of leaf scar & above and below & Angle of cushion spirals & \\
\hline & & Position of ligule & & & \\
\hline & & External parichnos & & & \\
\hline & & Lateral lines & & & \\
\hline & & Dissimilarity of adaxial and abaxial surfaces & & & \\
\hline & & Epidermal characters & & & \\
\hline & Leafy shoots & Epidermal characters & Leaf orientation on stem & Leaf shape & Leaf size \\
\hline & Isolated leaves & Epidermal details & Stomatal grooves & Shape & Size \\
\hline & Cones & Spore content & Shape of sporophylls & Size & \\
\hline & Isolated sporophylls & Spore content & Lamina shape & Lamina size & \\
\hline & & Epidermal detail & & Sporangium size & \\
\hline & Rooting organs & & & & All \\
\hline \multirow[t]{6}{*}{ Sigillariostrobaceae } & Stems & Ribs or spirals of cushions & Vertical distance apart & Size of leaf scars & \\
\hline & & Shape of scar & of scars on ribs & & \\
\hline & & Lateral lines & & & \\
\hline & & Surface markings & & & \\
\hline & Cones & Spore content & Shape of sporophylls & Size & Cone axes \\
\hline & Rooting organs & & & & All \\
\hline
\end{tabular}

- Zwickau: Schneider et al. (2005b) and Thomas (1997, 2005, 2007).

- Upper Silesia: Kotasowa (1979).

- Dobrudzha: Tenchov (1987) and Thomas \& Tenchov (2004).

The changing species diversities for the six coalfields with the most complete data are shown in Fig. 30. Sigillaria is often described as growing in less waterlogged conditions than the other arborescent lycopsids and its species diversity differs from the other genera except in Saar-Lorraine. Saar-Lorraine also has the lowest species diversity of all genera, but this maybe because Laveine (1989), on whose work these diversity curves was based, did not record the ranges of all of the species that have been recorded by others from this coalfield (Tables 4-5). In the Central Pennines and the Ruhr, where the drainage patterns were changing in Bolsovian times, there is a noticeable drop in species diversity, with Sigillaria disappearing first. Why there is a much greater species diversity in the Ruhr is not clear. In South Wales where the sequence is continuous, there is a drop in diversity just before the end of Bolsovian times with Sigillaria then being reduced to two species. The greatest species diversity in Bolsovian times is in Central Bohemia where it peaks in the lower part of this interval. This may be due to the higher elevation of this basin complex, resulting in a rapid rise in endemism. The Sydney basin extends from the upper Bolsovian to the lower Cantabrian substages. Here the diversity of the lycopsids steadily increases until it falls off at the Asturian-Cantabrian boundary. Sigillaria is only present here in the upper Asturian. The Asturian-Cantabrian substages in Central Bohemia show wide diversity in both Sigillaria and the other lycopsids peaking just before the end of the Asturian. This again is almost certainly due to endemism in this elevated basin complex.

The biogeographical relationships between the lycopsid floras were investigated using cluster analysis and Detrended Correspondence Analysis (Fig. 31). Separate analyses were done for the Bolsovian, the early Asturian, and the late Asturian early Cantabrian floras. There are problems in making such comparisons. Firstly, only six of the thirteen coalfields have both Bolsovian and lower Asturian strata, and only eight have upper Asturian / lower Cantabrian strata. Three coalfields have only upper Asturian / lower Cantabrian strata. Then, it was decided that there is the need to omit genera that have a very limited known distribution because they would affect the comparisons to a much greater extent than they deserve. Within this omission I include fructifications because reliable identification requires knowledge of their in situ spores which is still very limited in many coalfields. Leafy shoots have also been omitted, as they can only be identified meaningfully if cuticles are available, and these have been very little studied. As a result, the comparisons are restricted to the commonest stem genera - Bothrodendron, Lepidodendron, Lepidophloios, Sigillaria and Ulodendron.

For the Bolsovian macrofloras, both cluster analysis and DCA show a clear separation of the intramontane basins of central Europe plus the marginal areas of the Variscan foreland from 
Table 5. Biogeographical distribution for morphospecies of reproductive organs of lycopsids in Variscan Euramerica. $1=$ occurs in Paripteris linguaefolia Zone; 2 = occurs in Linopteris obliqua Zone; 3 = occurs in Lobatopteris vestita and/or Odontopteris cantabrica Zone.

\begin{tabular}{|c|c|c|c|c|c|c|c|c|c|c|c|c|c|}
\hline & 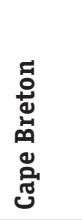 & 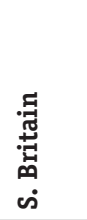 & 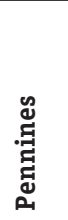 & 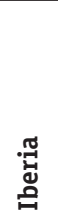 & 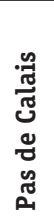 & 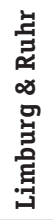 & 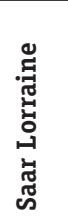 & 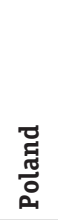 & 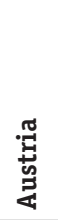 & 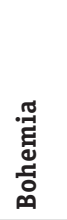 & 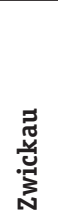 & 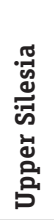 & 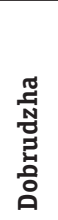 \\
\hline Flemingites crassus Němejc & & & & & & & & & & 3 & & & \\
\hline Flemingites dubius Binney & 3 & & 1 & & & & & & & & & & \\
\hline Flemingites russelianus (Binney) Brack-Hanes \& Thomas & 3 & 3 & 1,2 & & & & & & & & & & 3 \\
\hline Flemingites olryi Zeiller & & & 1,2 & & & 1 & 1 & & & & & & \\
\hline Lepidostrobus hofmanni Němejc & & & & & & & & & & 3 & & & \\
\hline Lepidostrobus obovatus Renier & & & & & & & & & & 3 & & & \\
\hline Lepidostrobus ronnaensis Bek \& Opluštil & & & & & & & & & & 3 & & & \\
\hline Lepidostrobus silesiacus Zdanowski \& Zakova & & & & & & & & & & & & 1 & \\
\hline Lepidostrobus stephanicus Němejc & & & & & & & & & & 3 & & & \\
\hline Lepidostrobus sternbergii Corda & & & & & & & & & & 3 & & & \\
\hline Lepidostrobus thomasii Bek \& Opluštil & & & & & & & & & & 3 & & & \\
\hline Lepidostrobophyllum acuminatum Bell & & 2 & & & & & & & & & & & 3 \\
\hline Lepidostrobophyllum alatum Boulter & 3 & 2,3 & & & & & & & & & & & \\
\hline Lepidostrobophyllum braidwoodensis Arnold & & & 1 & & & & & & & & & & \\
\hline Lepidostrobophyllum brevifolium (Lesquereux) Chaloner & & 3 & & & & & & & & & & & \\
\hline Lepidostrobophyllum hastatum (Lesquereux) Chaloner & & 3 & & & & 1 & 1 & & & & & & \\
\hline Lepidostrobophyllum jenneyi (D.White) Bell & 2,3 & & & & & & & & & & & & \\
\hline Lepidostrobophyllum lancifolium (Lesqu.) Oleksyshyn & & 3 & & & & & & & & & & & 1,3 \\
\hline Lepidostrobophyllum lanceolatum (Lindl. \& Hutton) Bell & 1,3 & $1,2,3$ & 3 & 3 & & 1 & 1,2 & & & 1,3 & 3 & & 3 \\
\hline Lepidostrobophyllum lyopoditis Feistmantel & & & & & & & & & & 1 & & & \\
\hline Lepidostrobophyllum majus (Brongniart) Hirmer & & & & 3 & & & & & & 1,3 & 3 & & 1,3 \\
\hline Lepidostrobophyllum mintoense Bell & $1,2,3$ & & & & & & & & & & & & \\
\hline Lepidostrobophyllum triangulare (Zeiller) Bell & & 3 & & & & & & & & & & & \\
\hline Lepidostrobophyllum sp. & & & & & & & & & & 3 & 3 & $\mathrm{x}$ & \\
\hline Sigillariostrobus cf. crepini Zallesky & 3 & & & & & & & & & & & & \\
\hline Sigillariostrobus major Zeiller & & & & & & & & & & 3 & & & \\
\hline
\end{tabular}

the lowland basins of the Variscan foreland. The position of the intramontane Saar-Lorraine appears anomalous as it clusters with the lowland basins of western Europe rather than with the other intramontane basin (central Basin) as it does with the pteridosperm analyses (Cleal, 2008c, 2008d). However, this may be a consequence of the lack of recent taxonomic work on the Saar-Lorraine lycopsids rather than their intrinsic biogeographical position. It is notable that the Pennines Basin, in the northern, cratonic part of the Variscan foreland, lies on the margins of the group of lowland basins in both the cluster analysis and DCA. As in an earlier preliminary study (Thomas, 2007) the Canadian Maritimes separates out on its own in both analyses, most probably due to endemic species.

There are fewer basins with Lower Asturian macrofloras but the cluster analysis still divides them into two distinct blocks, approximating to the lowland basins of the Variscan foreland, and the more upland intramontane basins. This division is also broadly evident on Axis 1 of the DCA plot. The obvious discrepancy is the grouping of Saar-Lorraine with the intramontane basins in both analyses, although this may merely reflect the lack of recent taxonomic work on the lycopsids of this basin.

The intramontane Zwickau and Austrian basins appear in this analysis for the first time in the upper Asturian - lower Cantabrian dataset. Once again the intramontane, more upland, basins form a clearly-defined group in the cluster analysis and the DCA. The other basins can be divided into three groups: the Canadian Maritimes, Iberia (with the Pennines) and Southern Britain. The separation of the Iberian floras agrees essentially with the pteridosperm results, where they are assigned to their own palaeoprovince, although why the Pennines also clusters here is unclear. The separation of the Canadian Maritimes and Southern Britain is also difficult to explain, as they tend to group together in the pteridosperm analyses. 
Table 6. Biogeographical distribution for morphospecies of vegetative organs of lycopsids in Variscan Euramerica. $1=$ occurs in Paripteris linguaefolia Zone; 2 = occurs in Linopteris obliqua Zone; 3 = occurs in Lobatopteris vestita and/or Odontopteris cantabrica Zone.

\begin{tabular}{|c|c|c|c|c|c|c|c|c|c|c|c|c|c|}
\hline & 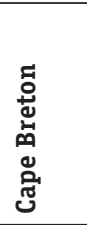 & 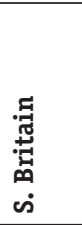 & 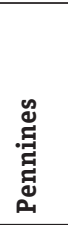 & 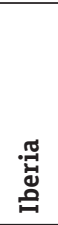 & 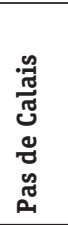 & 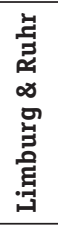 & 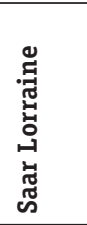 & 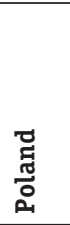 & 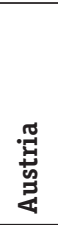 & 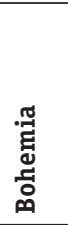 & 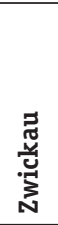 & 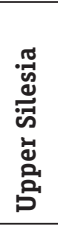 & 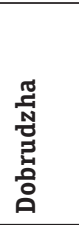 \\
\hline Lepidodendron aculeatum Sternberg & 2,3 & $1,2,3$ & 1,2 & $\mathrm{cf}$ & 1,2 & 1 & $1,2,3$ & 1 & 3 & 1,3 & 3 & $\mathrm{x}$ & $1,2,3$ \\
\hline Lepidodendron acutum Sternberg & $1,2,3$ & $1,2,3$ & 1,2 & & & & & & & 1,3 & & & \\
\hline Lepidodendron arberi Thomas & & 3 & & & & & & & & & & & 2 \\
\hline Lepidodendron bretonense Bell & 2,3 & & & & & & & & & & & & \\
\hline Lepidodendron dawsoni Bell & $1,2,3$ & & & & & & & & & & & & \\
\hline Lepidodendron dichotomum Sternberg & & $1,2,3$ & 1 & & & & & & & 3 & 3 & & 1 \\
\hline Lepidodendron feistmanteli Zalessky & & & 1 & & & & & & & & & & \\
\hline Lepidodendron fusiforme (Corda) Unger & & 3 & & & & & & & & & & & 1 \\
\hline Lepidodendron jaraczewskii Zeiller & & 1 & & & & & & & & & & & 1 \\
\hline Lepidodendron lanceolatum Lesquereux & 3 & 3 & 1,2 & & & & & & & & & & \\
\hline Lepidodendron lycopodioides Sternberg & 3 & $1,2,3$ & & & & 1 & $1,2,3$ & & & 3 & & & \\
\hline Lepidodendron mannabachense Presl & $1,2,3$ & $1,2,3$ & 1 & & & 1 & 1,2 & 1 & & 1,3 & & $\mathrm{x}$ & $1,2,3$ \\
\hline Lepidodendron ophiurus Brongniart & & $1,2,3$ & 1,2 & & & & & & & 1 & & & 3 \\
\hline Lepidodendron pictoense Bell & 3 & & & & & & & & & & & & \\
\hline Lepidodendron rimosum Sternberg & $\mathrm{x}$ & 1,2 & 1 & & & & & & & 3 & 3 & & \\
\hline Lepidodendron scutum Lesquereux & & & & 3 & & & & & & & & & \\
\hline Lepidodendron serpentigerum Koenig & & & & & & 1 & 1 & & & & & & \\
\hline Lepidodendron andrewsii Lesquereux & & 3 & & & & & & & & 3 & 3 & & 3 \\
\hline Lepidodendron wedekindii Weiss & & & & & & & & & & & & & 1 \\
\hline Lepidodendron wortheni Lesquereux & 2,3 & 2,3 & 1,2 & & & 1 & 1 & & & 3 & & & 3 \\
\hline Lepidodendron sp. & & & 3 & & & & & & & & & & \\
\hline Lepidophloios acerosus Lindley \& Hutton & & $1,2,3$ & 1,2 & & & & & & & 1,3 & & & 1 \\
\hline Lepidophloios laricinus Sternberg & 2,3 & $1,2,3$ & 1,2 & & & 1 & $1,2,3$ & & 3 & 1,3 & 3 & $\mathrm{x}$ & 1,3 \\
\hline Lepidophloios sp. & & & 3 & 3 & & & & & 3 & & & & \\
\hline Sigillaria boblayi Brongniart & 1 & 1 & & 3 & & 1 & 1 & & & & & & \\
\hline Sigillaria brardii Brongniart & 3 & 3 & 3 & 3 & & & & & & 3 & & & 3 \\
\hline Sigillaria candollei Brongniart & & & & 3 & & & 1 & & & & & & \\
\hline Sigillaria davreuxi Brongniart & & & & & & & & & & 1 & & & 1 \\
\hline Sigillaria elegans (Sternberg) Brongniart & 3 & & & & & & & & & & & & \\
\hline Sigillaria elongata Brongniart & 1 & 1 & 1 & & & 1 & 1 & 1,3 & & 1 & 3 & & 1 \\
\hline Sigillaria geinitzi Schimper & & & & & & & & & & 1 & 3 & & \\
\hline Sigillaria ichthyolepis Presl & 3 & & 1 & & & & & & & 3 & & & \\
\hline Sigillaria kidstoni Crookall & & & 1 & & & & & & & & & & \\
\hline Sigillaria laevigata Brongniart & 2,3 & $1,2,3$ & 1 & & & 1 & 1 & & & & & & \\
\hline Sigillaria lorowayi Dawson & 3 & 3 & & & & & & & & & & & \\
\hline Sigillaria macmurtriei Kidston & & 3 & & & & & & & & & & & \\
\hline Sigillaria mamillaris Brongniart & 3 & 1 & 1 & & 1,2 & 1 & $1,2,3$ & & 3 & 1,3 & & & $1,2,3$ \\
\hline Sigillaria nortonensis Kidston & & 3 & & & & & & & & & & & \\
\hline Sigillaria oculata Schlotheim & & & & & & & & 3 & & 3 & $\mathrm{x}$ & $\mathrm{cf}$ & 2,3 \\
\hline Sigillaria ovata Sauveur & 1 & 2,3 & 1 & & & 1 & 1 & & & & & & \\
\hline Sigillaria polleriana Brongniart & & & & & & & & 3 & & 1 & & $\mathrm{cf}$ & \\
\hline Sigillaria principis Weiss & & & 1 & & & & 2 & & & & & & \\
\hline Sigillaria pseudomicrostigmaria Zdanowski \& Zakowa & & & & & & & & 1 & & & & & \\
\hline Sigillaria reniformis Brongniart & & 1,3 & 1 & & & & & & & & & & \\
\hline Sigillaria rugosa Brongniart & & 3 & 1 & & & 1 & 1 & 1,3 & & 1,3 & & & 1,2 \\
\hline
\end{tabular}




\begin{tabular}{|c|c|c|c|c|c|c|c|c|c|c|c|c|c|}
\hline & 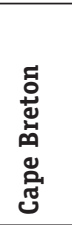 & 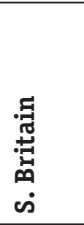 & 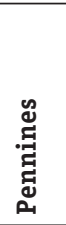 & 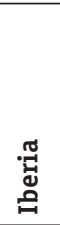 & 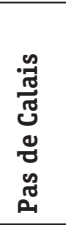 & 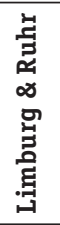 & 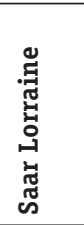 & 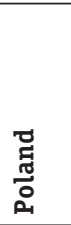 & 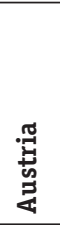 & 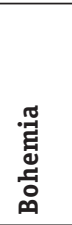 & 葛 & 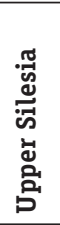 & $\begin{array}{l}\text { 芯 } \\
\text { స్ }\end{array}$ \\
\hline Sigillaria sauveri Zeiller & & & 1 & & & 1 & 1 & & & & & & \\
\hline Sigillaria scutellata Brongniart & 2,3 & 3 & 1 & & & 1 & 1 & & & 1 & & & \\
\hline Sigillaria tessellata Brongniart & 2,3 & $1,2,3$ & 1,2 & & 1,2 & 1 & 1 & & & 3 & 3 & & \\
\hline Sigillaria transversalis Boulay & & 3 & & & & & & & & & & & \\
\hline Sigillaria trigona Sternberg & 3 & & & & & & & & & 1,3 & & & \\
\hline Sigillaria voltzi Brongniart & & & & & & & & 1,3 & & & & & \\
\hline Cyperites bicarinatus Lindley \& Hutton & 3 & 2 & & & & & & & 3 & & 3 & & 1,3 \\
\hline Selaginella gutbieri (Göppert) Thomas & 2,3 & 3 & & & & & $1,2,3$ & & & 3 & 3 & & \\
\hline Selaginella leptostachys (Goldenberg) Thomas & & & & & & & 2 & & & 3 & & & \\
\hline Selaginella macrophylla (Goldenberg) Thomas & & & & & & & 2 & & & & & & \\
\hline Selaginella primaeva (Goldenberg) Thomas & & & & & & & 1 & & & & & & \\
\hline Selaginella stachygynandroides (Gutbier) Thomas & & & & & & & & & & & 3 & & \\
\hline Selaginella zeilleri (Halle) Thomas & & & & & & & & & & 3 & 3 & & \\
\hline Asolanus camptotaena Wood & 3 & $1,2,3$ & & & & 1 & 1,2 & 1 & & 1,3 & & & \\
\hline Bothrodendron minutifolium (Boulay) Zeiller & & 1 & 1 & & & 1 & 1 & & & 1 & & & 1 \\
\hline Bothrodendron punctatum Lindley \& Hutton & & $1,2,3$ & 1 & & & & & & & & & & \\
\hline Omphalophloios anglicus (Sternberg) Kidston & & 3 & & & & & & & & & & & \\
\hline Omphalophloios feistmanteli Němejc & & & & & & & & & & 1 & & & \\
\hline Omphalophloios orzechensis Bode & & & & & & & & 1 & & & & & \\
\hline Omphalophloios rugosus Bode & & & & & & & & 1 & & & & & \\
\hline Pinakodendron sp. & & & & & & & & 1 & & & & & \\
\hline Polysporia mirabilis Newberry & & & & & & & & & & 3 & & & \\
\hline Polysporia robusta Drabek & & & & & & & & & & 1,3 & & & \\
\hline Ulodendron majus Lindley \& Hutton & 3 & $1,2,3$ & & & & 1 & 1 & & & 1,3 & & & \\
\hline
\end{tabular}

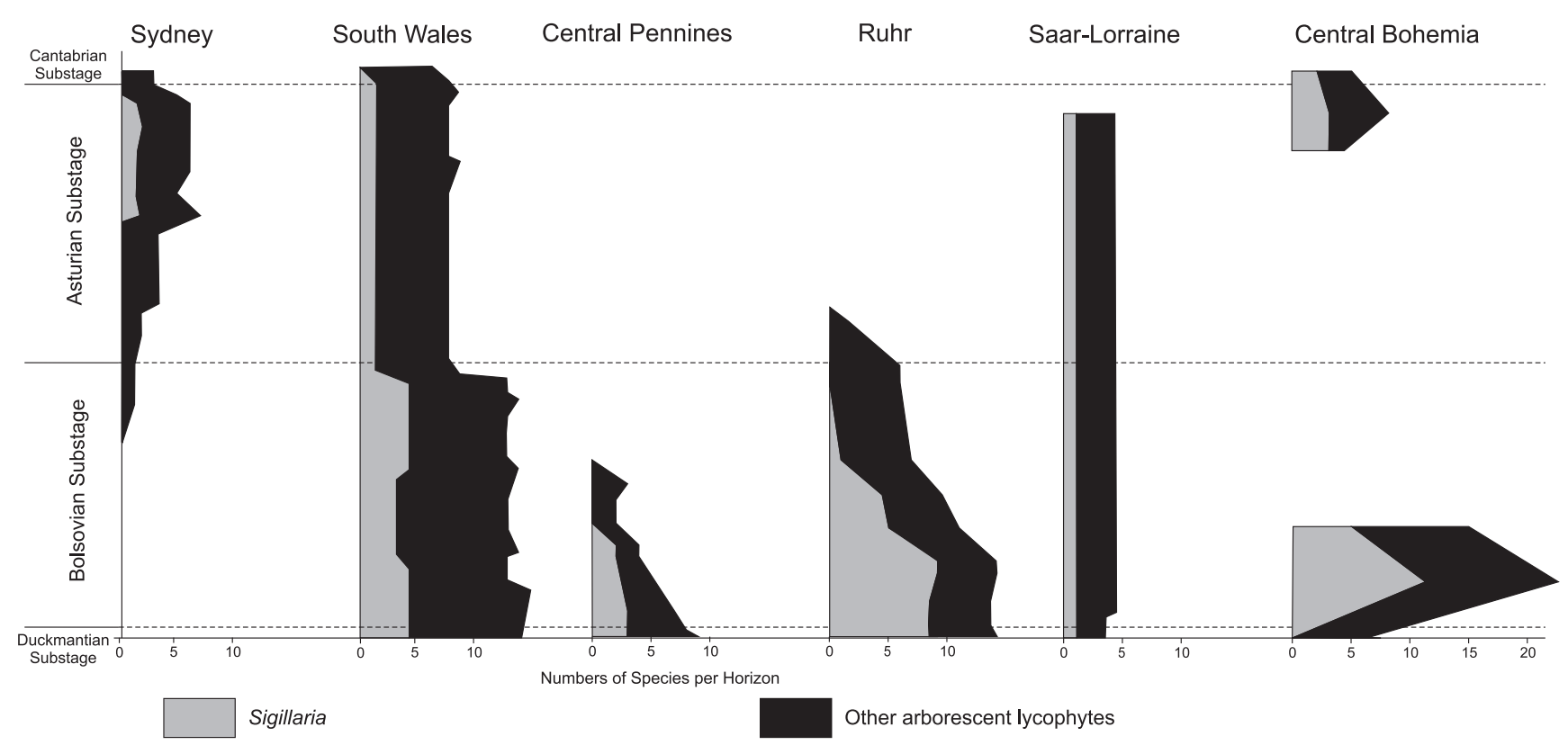

Fig. 30. Species diversity changes among arborescent lycopsids (indicated by bark morphology morphospecies) through the upper Westphalian and lowermost Stephanian stages in six of the best-documented coal basins of Variscan Euramerica. Data from the Sydney Coalfield based on Bell (1938), with additions by E.L. Zodrow and the author; from South Wales based on Cleal (2007); from the Pennines based on Cleal (2005, 2008b), from the Ruhr based on Josten (1991) and Josten \& van Amerom (1999); from Saar-Lorraine based on Laveine (1989); and from Central Bohemia based on Šimůnek in Pešek et al. (2001). 

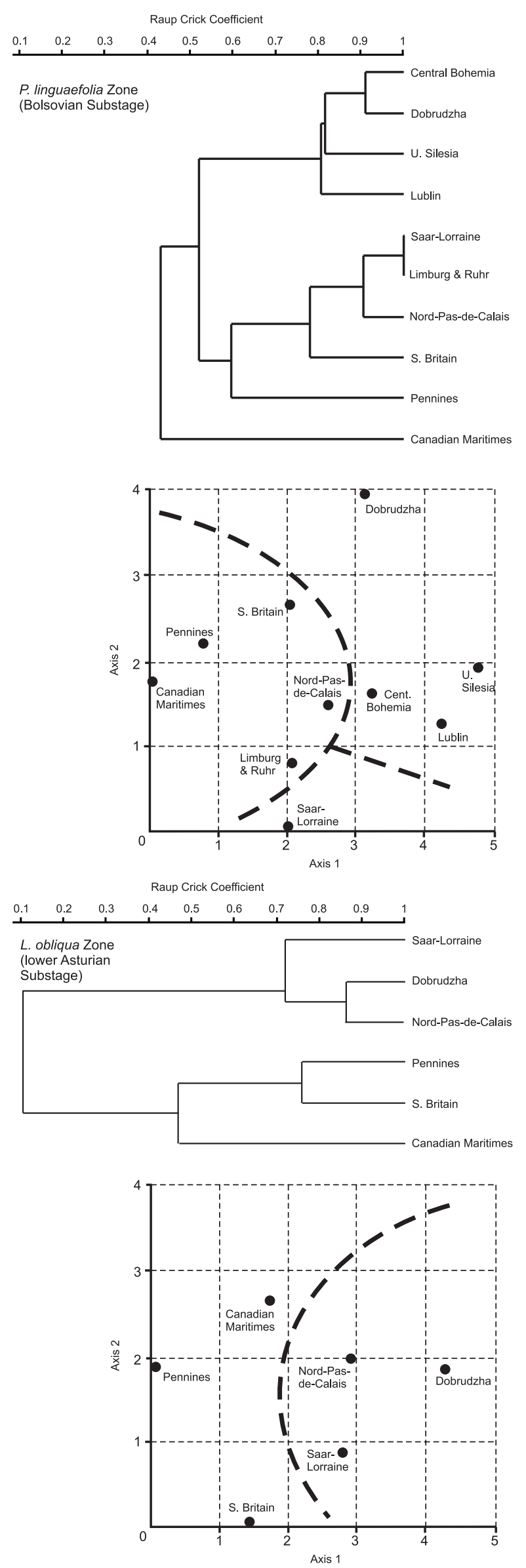
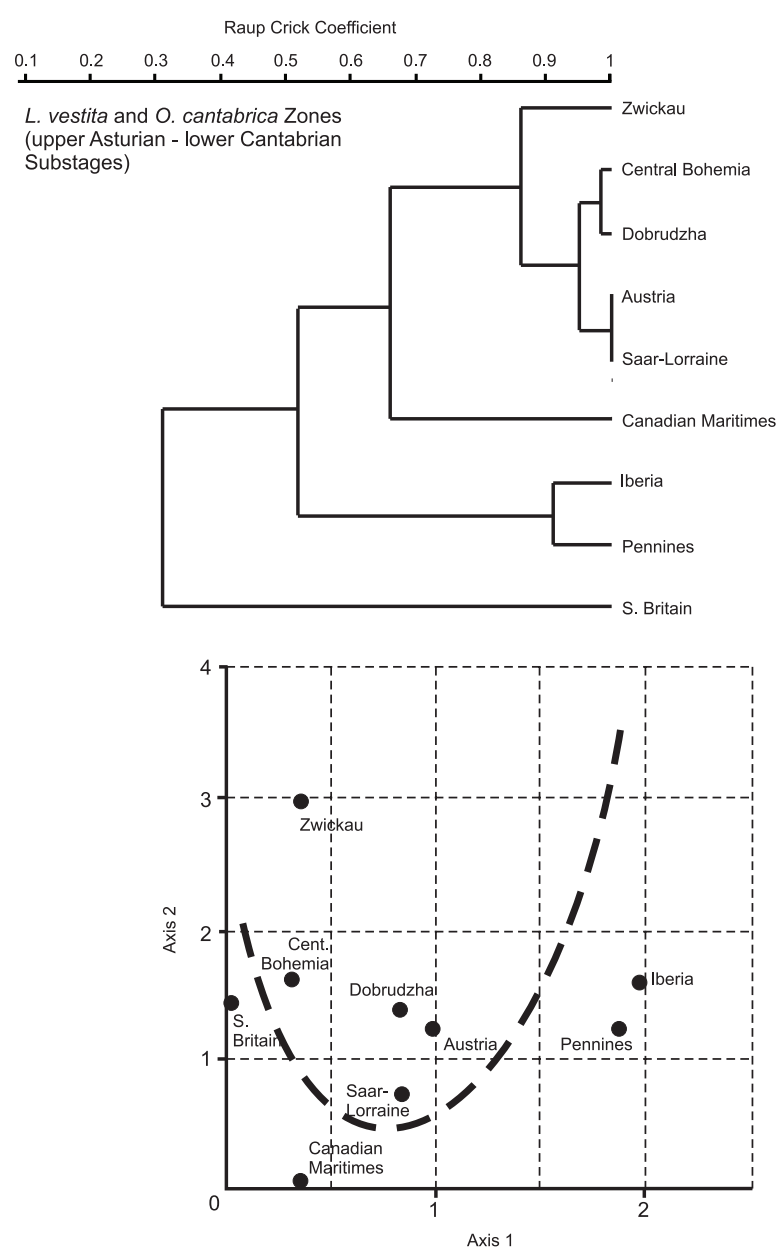

Fig. 31. Cluster analyses and Detrended Correspondence Analyses for the arborescent lycopsid dataset for Variscan Euramerica (data shown in Tables 27-28).

The results all show some consistent distinction between the more upland areas (the intramontane basins and the marginal areas of the Variscan foreland) and the lowland parts of the Variscan foreland in western Europe, reflecting the fact that some species are more common in one or the other habitat. For example, Lepidodendron rimosum, Sigillaria elongata, S. geinitzi, $S$. oculata and $S$. trigona are found in the intramontane basins, while Lepidodendron fusiforme, Sigillaria laevigata, S. ovata and S. scutellata are found more in the more lowland basins. A notable feature is that, unlike with the pteridosperms, there is no clear-cut difference between the intramontane basins and the marginal basin of the Variscan foreland, such as Upper Silesia and Dobrudzha. This may reflect the different dispersal strategies of these two groups of plants: the spores of the lycopsids could spread from basin to basin more readily than the large ovules of the pteridosperms. The biogeographical patterns in the lycopsids would thus have been more influenced by differences in climate or substrate, whereas the pteridosperm patterns would be more affected by vicariant separation of the floras. 
Both species diversities and biogeographical patterns in lycopsids thus seem to have remained essentially constant through late Westphalian and early Stephanian times in Variscan Euramerica. As with the pteridosperms, there is little evidence of significant change in climate or other extrinsic factors at this time.

\section{Sphenophyllaleans (J. Bek \& M. Libertin)}

Vegetative remains of these plants are assigned to the genus Sphenophyllum Koenig, 1825, a name that has had to be conserved against the earlier synonyms Rotularia Sternberg, 1821 and Sphenophyllites Brongniart, 1822. The anatomy of the stems was first described by Dawson (1866). Compressions of sphenophyllalean cones were described as compressions by Presl in Sternberg (1838) (as Rotularia marsileafolia Presl) and later by Germar (1844) and Geinitz (1855). Binney (1871) later proposed the name Bowmanites for structureless fragments of cones. The first description of petrified sphenophyllalean cones was by Williamson (1871) as Volkmannia dawsonii Williamson, which was later transferred to Bowmanites dawsonii by Weiss (1884) and made the type species of the genus Bowmanites. Seward (1898) proposed a new name Sphenophyllostachys Seward for cones of Sphenophyllum. In situ spores of sphenophylls were reported mainly by Hoskins \& Cross (1943), Remy (1955), T. N. Taylor (1969, 1970), Barthel (1976), W. A. Taylor (1968), Good (1978), Bek \& Opluštil (1998), and Libertín \& Bek (2008).

\section{Problems with identification of Sphenophyllum leaves}

The fossil remains of Sphenophyllum are mostly fragmentary and so many palaeobotanist have a problem with the clear identification of individual species. Sphenophyllum is a creeping lianescent plant which was able to climb up the stem of arborescent plants. The axes could be up to several metres long in most of sphenophyllacean species (Libertín \& Bek, 2008; Opluštil et al., 2009). Based on this life strategy, Sphenophyllum shows considerable variability in its leaves. Individual leaf morphotypes were attached to different orders of axes. The main axes had leaves which were markedly and deeply dentate with each end of the lamina hooked; or were lanceolate without the hooks. The other axes had more or less entire leaves (Bashforth \& Zodrow, 2007). Juvenile leaves were closely arranged but gradually drew apart during growth of the plant (Batenburg, 1977). It is therefore impossible to established comparative criteria for the identification of isolated leaves or whorls of leaves. Individual species can be better understood by using larger specimens bearing several types of leaves attached together, or several specimens each representing different types of leaves from one natural species from the same locality and stratigraphical level the useful characters are summarised in Table 7. At the present time, however, these difficulties prevent the group from being used consistently as a biostratigraphical indicator.

Additional problems that complicate the identification of individual species are as follows:

1. The distal ends of dentate leaves are mostly hooked, and the hooks are often partly buried in the matrix. This can lead to the wrong interpretation that the pinnules had an entire margin. Leaves must therefore be separated from the rock matrix for a precise description of their character.

2. Another important feature is leaf venation.

3. Epidermal structures have proved to be important diagnostic characters in sphenophylls (Abbott, 1958; Remy, 1955; Remy \& Remy, 1962; Meyen, 1970; Batenburg, 1977 and Barthel, 1997), but their study depends on the preservation of the specimen. The following features are noteworthy: the distribution of stomata, the orientation of guard cells, the average size of guard cells, the number and shape of subsidiary cells, intercostal cell size and shape of anticlinal walls.

\section{Problems with identification of sphenophyllalean cones}

There have been several approaches to the classification of sphenophyllalean cones. The first was published by Hoskins \& Cross (1943), who divided sphenophyllalean cones into three groups (Simplices, Jugati and Conferti) based on the number of sporangia per sporangiophore and their position on a sporangiophore. A second approach was suggested by Remy (1955), who proposed three genera of sphenophyllalean cones, Koinostachys, Aspidiostachys and Anastachys. Boureau et al. (1964) went further and proposed the division of sphenophyllalean cones into three families: Sphenophyllaceae (including Sphenophyllostachys Seward, Peltastrobus Baxter, Sphenostrobus Levittan \& Barghoorn and Lithostrobus Mamay), Cheirostrobaceae (only genus Cheirostrobus Scott) and Tristachyaceae (only genus

Table 7. Main characters that can be used to identify the main parts of sphenophylalean fossils.

\begin{tabular}{lllll}
\hline Organ & Useful features & Sometimes useful features & Not always useful features & Useless features \\
\hline Stems & & Type of stele & Type of branching & Size of stems \\
\hline Leafy shoots and isolated leaves & $\begin{array}{l}\text { Epidermal characters } \\
\text { Divisions of leaves } \\
\text { Venation }\end{array}$ & $\begin{array}{l}\text { Orientation of the leaves on the stem; } \\
\text { shape of the marginal teeth }\end{array}$ & Leaf shape; epidermal detail & Leaf size \\
\hline Cones & Bract shape & Type of spores & & \\
\cline { 2 - 5 } & Number of bracts & & Internode length & Cone size \\
\hline
\end{tabular}


Table 8. Biogeographical distribution for species of Sphenophyllum in Variscan Euramerica. $1=$ occurs in Paripteris linguaefolia Zone; 2 = occurs in Linopteris obliqua Zone; 3 = occurs in Lobatopteris vestita and/or Odontopteris cantabrica Zone.

\begin{tabular}{|c|c|c|c|c|c|c|c|}
\hline & Cape Breton & S. Britain & $\begin{array}{l}\text { Limburg \& } \\
\text { Ruhr }\end{array}$ & $\begin{array}{l}\text { Saar } \\
\text { Lorraine }\end{array}$ & $\begin{array}{l}\text { W \& Cent. } \\
\text { Bohemia }\end{array}$ & $\begin{array}{l}\text { Upper } \\
\text { Silesia } \\
\end{array}$ & Dobrudzha \\
\hline S. brasense Bek \& Libertin & & & & & 1 & & \\
\hline S. costae Sterzel & 3 & & & & & & \\
\hline S. cuneifolium (Sternberg) Zeiller & $1,2,3$ & 1 & 1 & $1,2,3$ & & 1 & 1 \\
\hline S. decorum Šetlík & & & & & 3 & & \\
\hline S. divsersiforme Šetlík & & & & & 3 & & \\
\hline S. emarginatum Brongniart & 2,3 & $1,2,3$ & 2 & 2,3 & 3 & 1 & \\
\hline S. cf. fosorum Renault in Zeiller & & & & & 3 & & \\
\hline S. geinitzii Storch & & & 2 & & & & \\
\hline S. kettneri Šetlík & & & & & 3 & & \\
\hline S. kidstonii Hemingway & & 1 & & & & & \\
\hline S. lineariformis Šetlík & & & & & 3 & & \\
\hline S. longifolium Germar & & & 2 & & & & \\
\hline S. majus Bronn & 1 & 1 & & 1 & 1 & & \\
\hline S. mirošoviense Daňková-Pokorná & & & & & 3 & & \\
\hline S. myriophyllum Crépin & 1 & 1 & & 1 & 1 & & \\
\hline S. oblongifolium (Germar \& Kaulfuss) Unger & 3 & 3 & & 3 & 3 & & \\
\hline S. orbicularis Remy & & & & 3 & & & \\
\hline S. pseudoaquense Bek \& Libertin & & & & & 1 & & \\
\hline S. saarense Remy & & & & 1 & & & 1 \\
\hline S. saxonicum Remy \& Remy & & & 1,2 & & & & 1 \\
\hline S. taylorii Bek \& Libertin & & & & & 1 & & \\
\hline S. tenuifolium Fontaine \& White & & & & & 3 & & \\
\hline S. trichomatosum Stur & & & & & & 1 & 1 \\
\hline S. wingfieldensis Hemingway & & 1 & & & 1 & & \\
\hline S. zwickawiense Storch & 1,2 & & 2,3 & & & & \\
\hline
\end{tabular}

Tristachya Lilpop). However, these previous divisions and classifications of sphenophyll cones are based only on their pure morphology, and excluded evidence of evolutionary trends, cones which are not three-dimensionally preserved, and their spores.

Fundamentally important for the natural taxonomic classification of these plants are the cones and their spores (Table 8). It is possible to determine and characterise natural taxa that can eventually revoke the parataxa that have been proposed for the different modes of preservation. Sterile stems with connected reproductive organs should be classified as Bowmanites. The genus Sphenophyllum is used only for leaves which are not associated with reproductive organs.

It is possible to divide Westphalian and Stephanian species of Bowmanites into five groups. Good (1978) proposed a similar classification based on the same principle but using permineralised material.

Group 1. Sphenophylls with decumbent stems only a few decimetres long and that lack climbing organs. Cones are simple with unbranched sporangiophores. These cones produced Punctatisporites obesus-type miospores.
Group 2. Sphenophylls with decumbent stems often more than one meter long. Leaves on older stems are prominently divided with hook-like tips. Cones possess branched and unbranched sporangiophores, and produced Vestispora-type miospores.

Group 3. Liana-like sphenophylls with stems a few metres long. Almost all leaves (excluding the youngest) have hook-like tips. Cones are only slightly compact, with branched sporangiophores bearing pyriform sporangia that produced monolete LaevigatosporitesLatosporites-type miospores.

Group 4. Stems more than one meter long. Leaves usually with hook-like tips (excluding the youngest). Hooked trichomes usually cover the whole stem. Cones are compact with branched sporangiophores and produced Pteroretis-type miospores.

Group 5. These poorly preserved cones had unbranched sporangiophores and produced Dictyotriletes-type miospores. 


\section{Distribution of Moscovian sphenophylls in Variscan Euramerica}

Sphenophyllum ranges from the Famennian Stage (Sphenophyllum subtenerrimum - Nathorst, 1902) to the Autunian 'Stage' (Sphenophyllum thonii, Sphenophyllum tenuifolium - Boureau, 1964), with maximum species diversity in the Westphalian and Stephanian stages. The distribution of species within seven basins of latest Duckmantian to early Cantabrian age are summarised in Table 8, based on the following records, and the authors' own observations. The records were based only on the genus Sphenophyllum as Bowmanites records are extremely rare.

- South Britain: Kidston (1901), Němejc (1953a), Kidston Collection (Keyworth), Natural History Museum (London) and, National Museum Wales (Cardiff).

- Dobrudzha Basin: Tenchov (2007c).

- Upper Silesia: Němejc (1953a), Purkyñová (1962) and the Ostrava collection.

- Cape Breton: Zodrow (1989) and Bashforth \& Zodrow (2007).

- Central and Western Bohemia: Němejc (1953a), DaňkováPokorná (1952), Pešek et al. (2001), Prague collection, Berlin collection and the Vienna collection.

- Saar Lorraine: Batenburg (1977), Barthel (1997), Němejc (1953q), Remy (1955) and the Berlin collection.

- Limburg and the Ruhr: Němejc (1953a), Remy (1955), Remy \& Remy (1962) and the Berlin Collection.

Much of the variation in diversity in the different areas is due mainly to differences in the level of investigation of the genus there. Nevertheless, some biologically significant variation is present in the data. Species variability is relatively high near the Bolsovian - Westphalian D boundary, while near the Westphalian D - Cantabrian boundary the species diversity is lower. Sphenophyllum inhabited the understory, creeping on the ground and climbing on stems. The influence of humidity on the genus was therefore probably marginal. However, Sphenophyllum would have reacted to changes in general composition of the overgrowth. One of the most notable changes was the decline of arborescent lycopsids during Stephanian times and their replacement by ferns and pteridosperms, resulting in a change to more open conditions. This change in conditions seems to have resulted in an increase in abundance of sphenophyllacean species with spores of the Laevigatosporites-Latosporites-type, while the other sphenophyllaceans went into decline.

\section{Ferns (J. Pšenička)}

The ferns have been an important and widely dispersed plant group and have colonized terrestrial habitats since Late Devonian times; they are typical components of Pennsylvanian tropical vegetation. The ferns have an extensive fossil record, which includes excellent examples showing both anatomy and gross morphology. Nevertheless, nearly all fossils are fragmentary remains, preserving only a portion of the plant body.
Pennsylvanian ferns could be small herbaceous plants, surface-creeping and climbing plants, or small trees. They are often split into three artificial groups based on character of their reproductive organs (sporangia): eusporangiate ferns (whose sporangia arose from several epidermal cells, with the sporangial wall composed of more than one cell-layer), leptosporangiate ferns (whose sporangia arose from a single epidermal cell, and whose sporangial wall is composed of one cell-layer) and transitional, proleptosporangiate ferns (whose sporangia arose from several epidermal cells, and whose sporangial wall is composed of one or more cell-layers). Herbaceous, surface-creeping and climbing forms were leptosporangiate and proleptosporangiate, while tree forms were eusporangiate (Marattiales).

Ferns have ventured into most ecological niches from ground cover, to epiphytes, to trees, and have grown in most kinds of habitats from fire swept, to swampy, to xeric, and have exploited resources with a range of life-history strategies, from opportunists to resource accumulators (DiMichele \& Phillips, 2002). Most fern species, especially the relatively modern leptosporangiate types, tend to be endemic elements of particular areas and so often do not occur at different localities or basins at the same stratigraphical levels. Consequently, leptosporangiate (and proleptosporangiate) fern fossils have tended not to be important in Palaeozoic biostratigraphy.

The situation with eusporangiate ferns is a little more complicated. Many, such as Pecopteris cyathea, P. arborescens and Lobatopteris miltoni, appear to be cosmopolitan species found in nearly all Pennsylvanian and Lower Permian localities. However, evidence from Lobatopteris miltoni has shown that this species that has been described from hundreds of localities in fact consists of more than one natural species (Pšenička et al., 2009). Each area has its own range of pinnule variability reflecting 1) intraspecific variability (ecological influence) or 2) different natural species. Consequently, using such ferns for biostratigraphy is very inexpedient and unwise.

\section{Problems with identification of species of small-fern}

Fern-like plants appear to be among the most easily-identifiable groups of plants based on their pinnate fronds, but this is at first sight only. Ferns show great pinnule/pinnae variability within any one species, especially so when comparing the fertile and sterile parts of one natural species.

Small ferns are represented by leptosporangiate and proleptosporangiate species. Brousmiche (1983) referred some genera of small ferns (Urnatopteris, Renaultia, Zeilleria, Myriotheca) to eusporangiate ferns, but she did not figure details of the reproductive organs (sporangia) to support this conclusion. Leptosporangiate and proleptosporangiate ferns are represented by several fertile fossil-genera, such as Oligocarpia, Hymenophyllites, Boweria, Sturia, Discopteris and others. The biostratigraphical value of small ferns is insignificant. In the 
Saar-Lorraine, for example, Zeilleria frenzlii (Stur) Kidston ranges stratigraphically from Duckmantian to Bolsovian in age (Brousmiche, 1983), whereas in Central Bohemian and Great Britain it ranges from Bolsovian to Asturian in age (Kidston, 1924; Pešek, 1994).

The occurrence of small ferns is dependent on the type of sedimentary setting and in particular on the distance of their transportation due to their delicate physique. Phillips et al. (1985) also indicated that small ferns were minor biomasscontributors, despite their species diversity, accounting for less than $10 \%$ of the total peat biomass.

Great problems exist with the classification of sterile specimens of true ferns that have sphenopteroid pinnules; they are often misidentified as pteridosperms, and conversely pteridosperms are sometimes misidentified as true ferns. The unequivocal recognition of true ferns is only possible based on fertile specimens where the reproductive organs are preserved. Consequently, many species separated into different fossilgenera can in fact belong to one natural species. This problem is complicated clearly by their inhomogeneous stratigraphical and geographical distributions.

\section{Problems with identification of marattialean tree ferns}

Marattialeans were studied by several authors (e.g. Stidd, 1974; Corsin 1951, 1955 and Němejc, 1940). Marattialeans, most often represented by pecopterids, are known from Bashkirian macrofloras, but their global radiation occurred in late Moscovian and Kasimovian times (DiMichele, 2002). Based on the palaeontological record, pecopterids did not become important in mires until Bolsovian times. Such assemblages were commonly 12-15 per cent of the biomass in late Asturian times (DiMichele \& Phillips, 1994). A change in the subgroups of pecopterids present can be observed between the Bolsovian and Asturian substages: members of the miltoni subgroup are characteristic of Bolsovian macrofloras, while members of the arborescens subgroup are typical for Asturian and Stephanian macrofloras. This effect can be observed in all basins of the Amerosinian realm.

The major problem with this group is the absence of clear attributes for the classification of individual species. The issues may be summarised as follows.

1. Pecopterids are very common species in Carboniferous-Permian localities of the world. Many authors have often used a new name for a species that occurs in their study area, ignoring older names although it is clear that they are conspecific (e.g. the type material of Pecopteris polypodioides (Sternberg) Němejc is specifically identical to some specimens described under name Pecopteris vestita Lesquereux; the type material of Diplazites emarginatus Göppert is identical with specimens described under name Pecopteris unita Brongniart).

2. Pecopterid frond belongs to tree ferns with fronds over $1 \mathrm{~m}$ long. Only fragments of fronds are normally found. In some cases, pinnules at the distal end of a frond are different when compared to the pinnules situated in lower positions (an example of this can be seen in Acitheca polymorpha (Brongniart) Schimper documented by Zodrow et. al., 2006). In some cases, this pinnule variability has resulted in the establishment of two or more different species for parts of the same frond.

3. Different states of preservation. A good example of this problem is the comparison of fertile specimens that are preserved as permineralisations (Scolecopteris) and compressions (Asterotheca).

4. Sterile and fertile pinnules (fronds) of one natural species are often of different appearance.

5. Many authors have not established a holotype. In many cases, species have been based on several specimens (type collection) containing more than one natural species. Later authors have used different specimens from that type collection when trying to interpret the species.

6. Type material is often fragmentary. A good example is the holotype of Pecopteris polypodioides (Sternberg) Němejc, which preserves only four pinnules from the distal part of an ultimate pinna.

7. Different authors give taxonomic significance to different features for the ferns.

8. Some authors give emphasis to the morphological characters of the pinnae and pinnules, together with venation patterns. This is clearly an example of the 'geological' point-of-view of the separation of pecopterids, as these characters allow for the quick determination of 'species'. However, failure to use reproductive organs as taxonomic parameters can lead to the splitting of natural species into two or more artificial species, as the morphology of the pinnules and pinnae can be different in the basal part and upper parts of these large fronds. This can lead to considerable confusion in this group.

From this summary, it is clear that it is quite impossible at present to compare seriously pecopterids from different localities, and therefore to develop any meaningful biogeographical or biostratigraphical models for these ferns. Such models will only be possible when there have been radical revision of the taxonomy of this fern group based on a combination of many parameters including frond architecture, pinnule morphology and cuticles, reproductive organs, and cuticle biochemistry (Pšenička et al., 2005).

\section{Sphenophytes (C. J. Cleal)}

Although Westphalian sphenophytes of Euramerica attracted considerable attention during the $19^{\text {th }}$ century (much of this work summarised by Jongmans, 1911) there have been few attempts at systematic revisions in more recent years. Pith casts and adpressions of the stems are the most abundant fossils, but these show relatively few characters and they vary according 
to where the fossil came from in the plant. Attempts to use branch scars as a means of naming fossil-taxa of these stems (Jongmans \& Kukuk, 1913; Kidston \& Jongmans, 1917 and Crookall, 1969) have generally proved unsatisfactory. Foliage adpressions are also commonly found in these floras and what appears to be a more stable fossil taxonomy has been established based mainly on gross morphology, although with some attempt to incorporate evidence of epidermal anatomy (Walton, 1936 and Abbott, 1958). Most of these foliage species have a wide geographical distribution across Variscan Euramerica. Some, such as Asterophyllites equisetiformis Brongniart, are also very long ranging stratigraphically, but others (e.g. Annularia sphenophylloides (Zenker) Gutbier) seem to have more limited stratigraphical distributions and have sometimes been used to aid stratigraphical correlation (e.g. Laveine, 1977).

Based purely on the foliage, the sphenophytes seem to show little provincialism across Variscan Euramerica. From Bolsovian, Asturian and Cantabrian macrofloras, Annularia radiata (Brongniart) Sternberg, Annularia sphenophylloides, Annularia stellata (Sternberg) Wood, Asterophyllites equisetiformis, Asterophyllites charaeformis (Sternberg) Unger, Asterophyllites grandis (Sternberg) Geinitz and Asterophyllites longifolius (Sternberg) Brongniart have all been recorded from Britain (Crookall, 1969; Cleal, 1997, 2005, 2007, 2008c), the Ruhr (Josten, 1991 and Josten \& Van Amerom, 1999), Upper Silesia (Kotasowa \& Migier in Zdanowski \& Żakowa, 1995), Dobrudzha (Tencov, 1987), Saar-Lorraine (Germer, 1971 and Laveine, 1989) and Central Bohemia (Šimůnek in Pešek et al., 2001). All of these species except for $A$. charaeformis and $A$. grandis are also known from the Sydney Coalfield (Bell, 1938), these species probably being absent because of the relatively low diversity of the Bolsovian macrofloras there. Laveine (1986) recorded A. stellata and $A$. sphenophylloides from Nord-Pas-de-Calais, and $A$. radiata but from Duckmantian macrofloras (Asterophyllites species were not covered in this paper).

Cones are less commonly preserved as fossils and, without anatomical evidence can be difficult to classify (Gastaldo, 1981). The most detailed attempt to study the morphology of these cones was by Němejc (1953b) based on specimens from Central Bohemia and he noted that there seemed to be more cone species than foliage species. This may be reflecting conservatism in foliage morphology, with more than one biological species having morphologically indistinguishable foliage. The further study of the epidermal anatomy of these leaves might potentially resolve this problem. Alternatively, however, Němejc may have taxonomically over-divided the cones, which may have varied considerably in form according to maturation. Bek \& Opluštil (1998) have demonstrated the potential of in situ spores for possibly resolving this issue.

The apparent lack of provincialism suggested by the foliage record could be a reflection of the palaeobiology of these plants. Their small spores (Bek \& Opluštil, 1998) would presumably allow them to be widely dispersed between different basins in both paralic and intramontane settings. Moreover, they seem to have favoured wet, clastic substrates (Gastaldo, 1992; Pfefferkorn et al., 2001) which are likely to have been a consistent feature of these swamp communities in both lowland and intramontane settings. On the other hand, the greater diversity suggested by the cones may indicate that we are missing details of the biogeography of these plants by only looking at the foliage. Investigating the distribution of the foliage and cone taxa in parallel might help resolve some of these difficulties.

\section{Pteridosperms (C. J. Cleal)}

Pteridosperms were a paraphyletic group of seed-plants that formed a major component of the coal swamp vegetation. During Westphalian times, they primarily grew on the clastic substrates within the swamps, notably sandbars and levees, but in Stephanian times they also occupied peat substrates (DiMichele et al., 2006). They were not the dominant plants in the swamps in terms of biomass but, because they favoured habitats that were often adjacent to sites of sedimentdeposition or flowing water, their remains often dominate macrofloras of this age (Cleal, 2007). Consequently, pteridosperms have been the subject of numerous taxonomic and biostratigraphical studies.

Among late Westphalian and early Stephanian pteridosperms, three orders are usually recognised, the Medullosales, Lyginopteridales and Callistophytales. The Lyginopteridales were the most primitive of the pteridosperms, and can be traced back to late Devonian times (Rothwell et al., 1989). By late Westphalian times the order was in decline and consisted mainly of scrambling bush-like plants and lianas. The late Westphalian and Stephanian species are usually assigned to just one family, the Lyginopteridaceae; a second family, the Mariopteridaceae, has been recognised by some authors for the plants that bore mariopteroid fronds but little is known about the anatomy or reproductive biology of these plants to justify their taxonomic separation.

The Callistophytales were ecomorphically similar to the Lyginopteridales, consisting also of scrambling or lianescent plants (Rothwell, 1975; Krings et al., 2001). However, they had a more sophisticated reproductive biology (Rothwell, 1981), and during late Westphalian and Stephanian times appear to have progressively out-competed and replaced the Lyginopteridales. Just one family is currently recognised, the Callistophytaceae.

The Medullosales were the most widespread, abundant and diverse of the three orders. There has been no agreement as to the classification of these plants at ranks between genus and order, which has not been helped by the anatomical conservatism of the ovules and cauline structures, and the very limited available evidence of attachment of reproductive and vegetative structures. However, Cleal \& Shute (2003) recognised four fossil-families, which although based mainly on evidence 
of the vegetative structures, was intended to reflect the original systematic arrangement of the parent plants.

1. Alethopteridaceae - mainly medium-sized trees with large fronds (Laveine, 1986) whose crown probably protruded above the surrounding vegetation (Cleal et al., in press).

2. Neurodontopteridaceae - smaller plants than those of the Alethopteridaceae; most Westphalian examples were monoaxial, upright plants that probably grew mainly in dense mutually-supporting thickets (Wnuk \& Pefferkorn, 1994), but in latest Westphalian and Stephanian times they were mainly scrambling plants.

3. Cyclopteridaceae - similar to the previous family, but with juvenile stages adapted to growing in dense undergrowth (Shute \& Cleal, 2002).

4. Potonieaceae - again, medium-sized trees with large fronds. The family probably originated in China but spread into Euramerica during Bashkirian times (Laveine et al., 1994).

In those basins where wetland conditions persisted throughout late Westphalian and earliest Stephanian times, the Medullosales show relatively stable species diversities (Fig. 32). The only notable change is the middle Asturian increase in diversity that has been widely recognised at the base of the Lobatopteris vestita Zone (e.g. Pfefferkorn \& Thomson, 1982; Cleal, 2007). In the lowland basins of the Variscan foreland, this is mainly attributable to the appearance of Alethopteris species of the A. ambigua / A. pseudograndinioides group, whereas in the intramontane basins it is due to the appearance of Callipteridium species. The diversities of the Cyclopteridaceae and Neurodontopteridaceae remain relatively unchanged, although within the former family Laveineopteris is progressively replaced by Callipteridium, and in the latter family Neuropteris is at least partly replaced by Odontopteris. This change is also probably reflecting a change in habit of the plants, from monoaxial, upright plants to smaller, scrambling plants.

In those basins such as the Pennines and the Ruhr, where changing drainage patterns were causing the wetland habitat to disappear, all of the medullosaleans appear to have declined in diversity. However, it is notable that the Alethopteridaceae tend to disappear from the fossil record in these basins earlier than the other medullosalean families. This, together with the observation made earlier that the intramontane basins do not show the middle Asturian increase in diversity of the Alethopteridaceae, suggests that this family was more closely adapted to the lowland wetland habitats.

A notable feature of these medullosalean diversity curves is the much higher diversities in the Bolsovian macrofloras of the Ruhr and Central Bohemia. In Central Bohemia, this is largely a consequence of a large number of endemic taxa (Šimůnek, 2007a) which in turn may reflect the relatively high elevation of this basin-complex (0pluštil, 2005). The higher diversity in the Ruhr, which can probably be matched by diversities in the Nord-Pas-de-Calais Coalfield (e.g. Buisine, 1961; Laveine, 1967) is less easy to explain. It possibly reflects the extensive taxonomic work that has been done on the floras in these basins, resulting in records of rare taxa that have been missed in other parts of the Variscan foreland. However, the present author has re-examined much of the extensive Kidston Collection from the British coalfields in a search for these rare species and, although a few were discovered (e.g. Laveineopteris dussartii

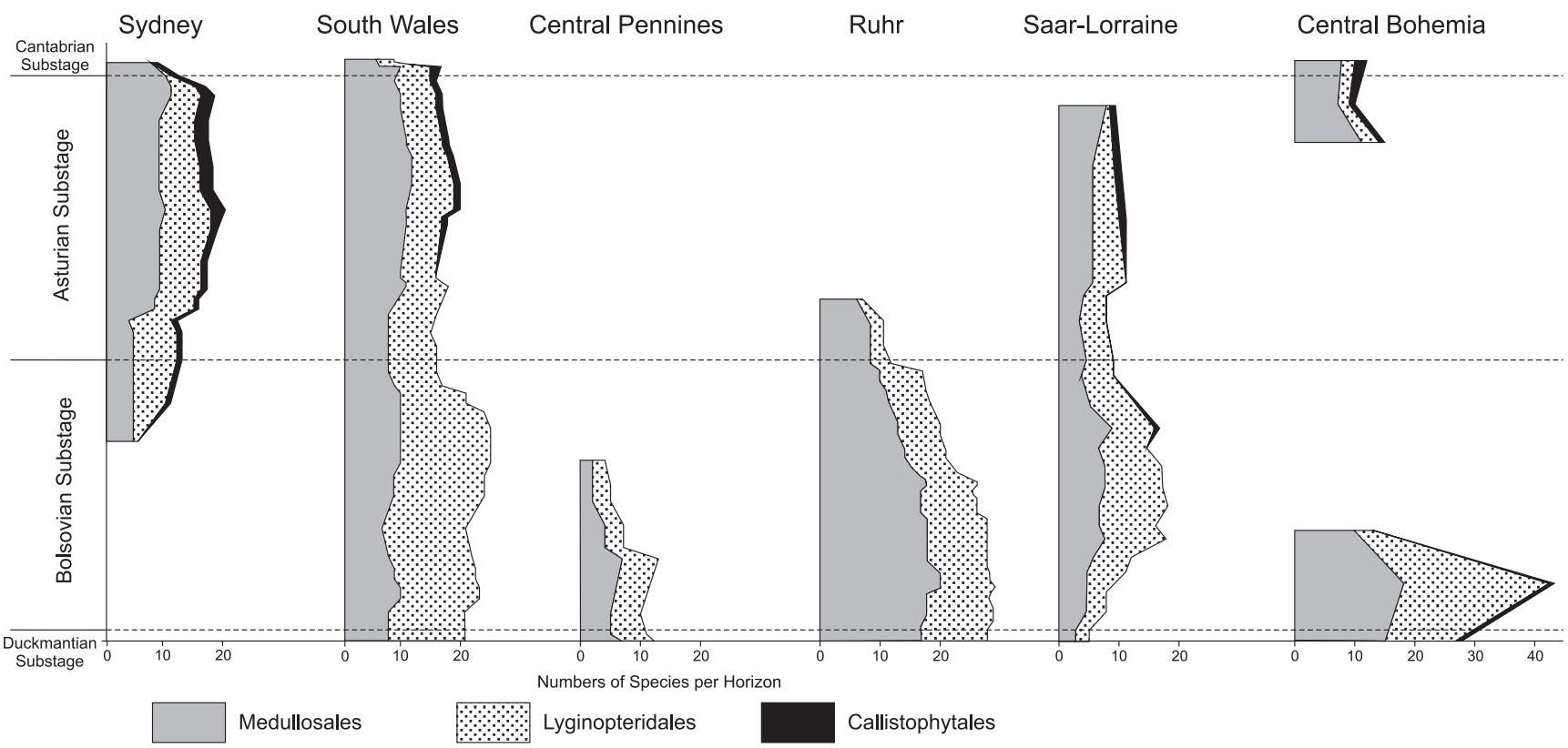

Fig. 32. Changing pteridosperm species diversities through the upper Westphalian and lowermost Stephanian stages in six of the best-documented coal basins of Variscan Euramerica. Data from the Sydney Coalfield based on Bell (1938), with additions by E.L. Zodrow; from South Wales based on Cleal (2007); from the Pennines based on Cleal (2005, 2008b), from the Ruhr based on Josten (1991) and Josten \& van Amerom (1999); from Saar-Lorraine based on unpublished work by Cleal; and from Central Bohemia based on Šimůnek in Pešek et al. (2001). 
(Laveine) Laveine, Laveineopteris jongmansii (Crookall) Cleal \& Shute - see Cleal, 1978; Cleal \& Shute, 1995), most appear to be absent from this country. The higher diversity of the Ruhr and Nord-Pas-de-Calais medullosaleans is therefore likely to be reflecting a real difference in the original vegetation, perhaps a function of their more southerly position on the Variscan foreland.

The Lyginopteridales, in contrast, undergo a marked decline during this interval. Most areas, including South Wales, the Central Pennines, the Ruhr and Saar-Loraine show an initial decline in upper Bolsovian macrofloras due to a reduction in eusphenopterid species, and then a further progressive decline in Asturian macrofloras through a loss of mariopteroid species. There is some correlation here with the increase in Callistophytales diversity and Cleal (2008d) has suggested that the Lyginopteridales plants were possibly being out-competed by their ecomorphic equivalents among the Callistophytales. Whilst this could perhaps explain the decline in mariopteroids, the decline in eusphenopterids started significantly before the callistophytaleans appeared in any abundance (i.e. late Bolsovian times).

Whilst the numbers of Medullosales and Lyginopteridales species are broadly similar in Bolsovian and Asturian macrofloras, the Medullosales far outweigh the Lyginopteridales in terms of biomass. This can be seen in the figures given by Davies (1929) for the South Wales Coalfield (Fig. 33) where the macrofloras of this age usually yield at least ten times the number of hand specimens of medullosaleans than of lyginopteridaleans (see Cleal, 2007, for discussion on the use of Davies's data as a proxy for plant biomass). DiMichele et al. (1991) found a somewhat lower proportion of medullosaleans to lyginopteridaleans in specimen and quadrat counts in an early Asturian macroflora from 0klahoma, although even here the medullosalean remains heavily (four-times) outweighed the lyginopteridalean biomass. Drägert (1964) also reported about five times more medullosalean than lyginopteridaleans biomass based on specimen counts from the lower Duckmantian Substage of the Ruhr. This difference in biomass of the two pteridosperm groups observed in these studies may be partly due to the medullosaleans being small trees, whereas the lyginopteridaleans were scrambling and lianescent plants. In modern-day tropical rain forests, for instance, lianas represent only about $2 \%$ of the total biomass (Nascimento \& Laurance, 2002). In contrast, Scott $(1977,1978,1979)$ suggested that there were relatively similar biomasses of these two pteridosperm groups in Duckmantian vegetation of northern Britain, but this discrepancy may be at least in part due to the different ways in which the data were collected and analysed.

This difference in the relative biomass of the major groups of pteridosperms has a practical consequence for the study of their distribution patterns. Since there are proportionally fewer fossils of the lyginopteridaleans than of the medullosaleans, this is likely to introduce potential sampling problems with the

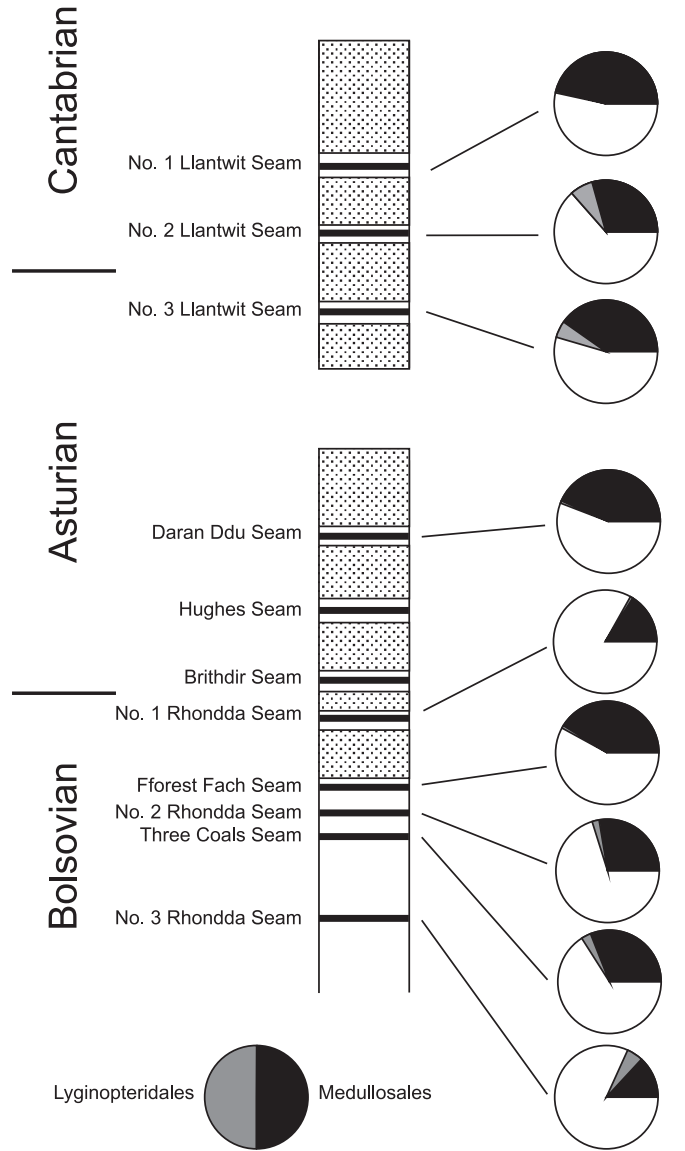

Fig. 33. Relative proportions of Medullosales and Lyginopteridales as measured in numbers of specimens collected from the upper Westphalian and lowermost Stephanian of the easter part of the South Wales Coalfield. Based on data from Davies (1929).

former group, especially with those macrofloras that have been less-intensively investigated. This appears to be reflected in the known stratigraphical ranges of pteridosperms in different basins across Variscan Euramerica. The patterns of appearances of medullosalean species tend to be relatively similar in the different basins where there are reliable data (Fig. 34). There are some exceptions, most notably in Saar-Lorraine where certain species appear later than elsewhere (e.g. Laveineopteris tenuifolia, Paripteris pseudogigantea, Macroneuropteris scheuchzeri), but on the whole the pattern of appearances is relatively consistent. Disappearances of species, perhaps not surprisingly, are a little less regular in different basins, but even here there is a general consistency in pattern. The lyginopteridalean species, in contrast, show much less consistent biostratigraphical ranges, even for those species that tend to be relatively more abundant and thus welldocumented (Fig. 35). This means that these species will tend to be less reliable as either biostratigraphical or biogeographical indicators.

Separate attempts have been made at biogeographical analyses of medullosalean and lyginopteridalean pteridosperms (Cleal, 2008d, 2008e). The medullosalean study revealed a 

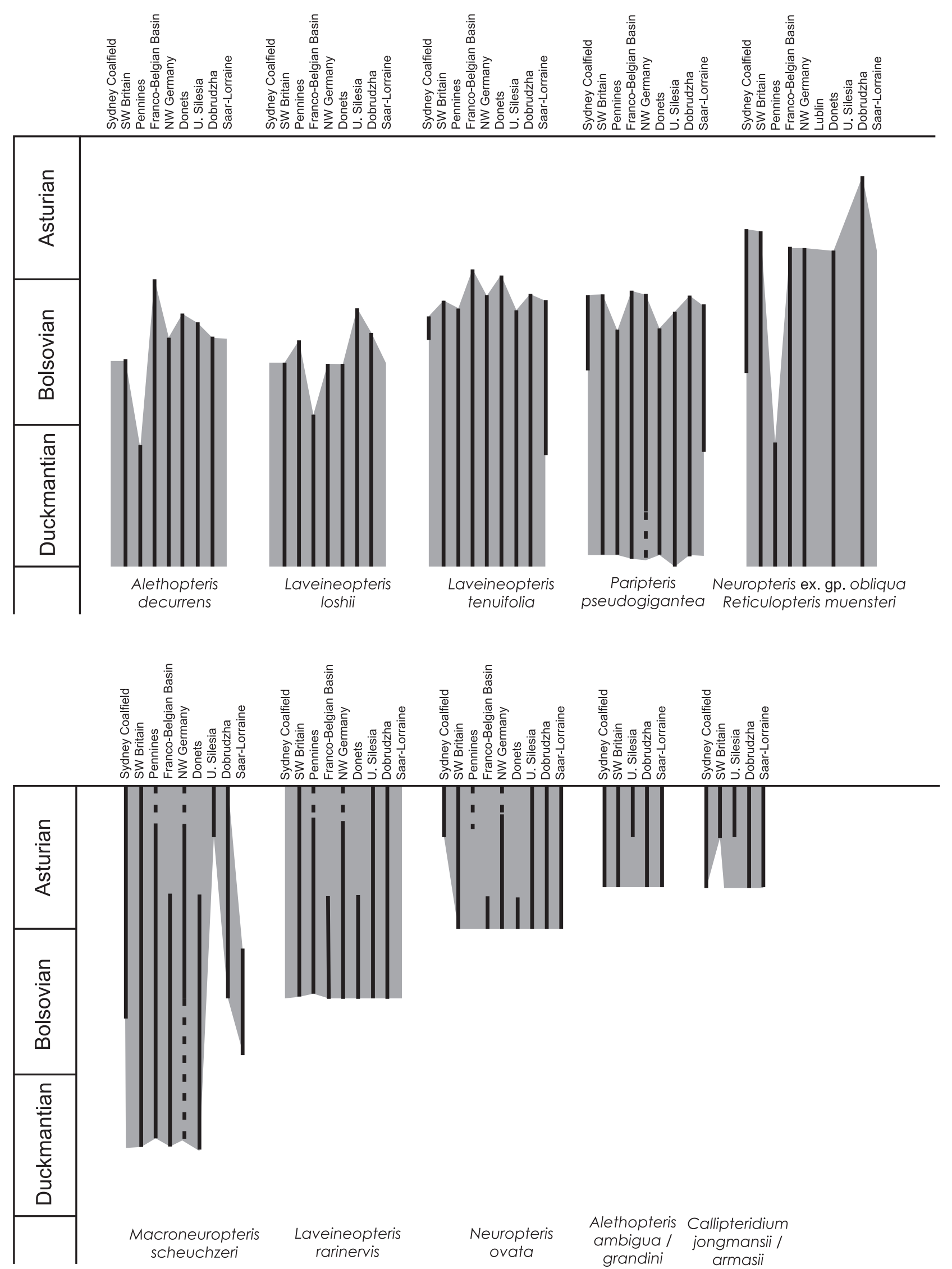

Fig. 34. Stratigraphical ranges of ten of the most widespread medullosalean species in the main coal basins of Variscan Euramerica. Data from same sources as in Fig. 32, plus Cleal et al. (2004) for Dobrudzha; Novik $(1952,1954)$ and Fissunenko \& Laveine (1984) for the Donets; and Kotasowa \& Migier in Zdanowski \& Żakowa (1995) for Upper Silesia. 


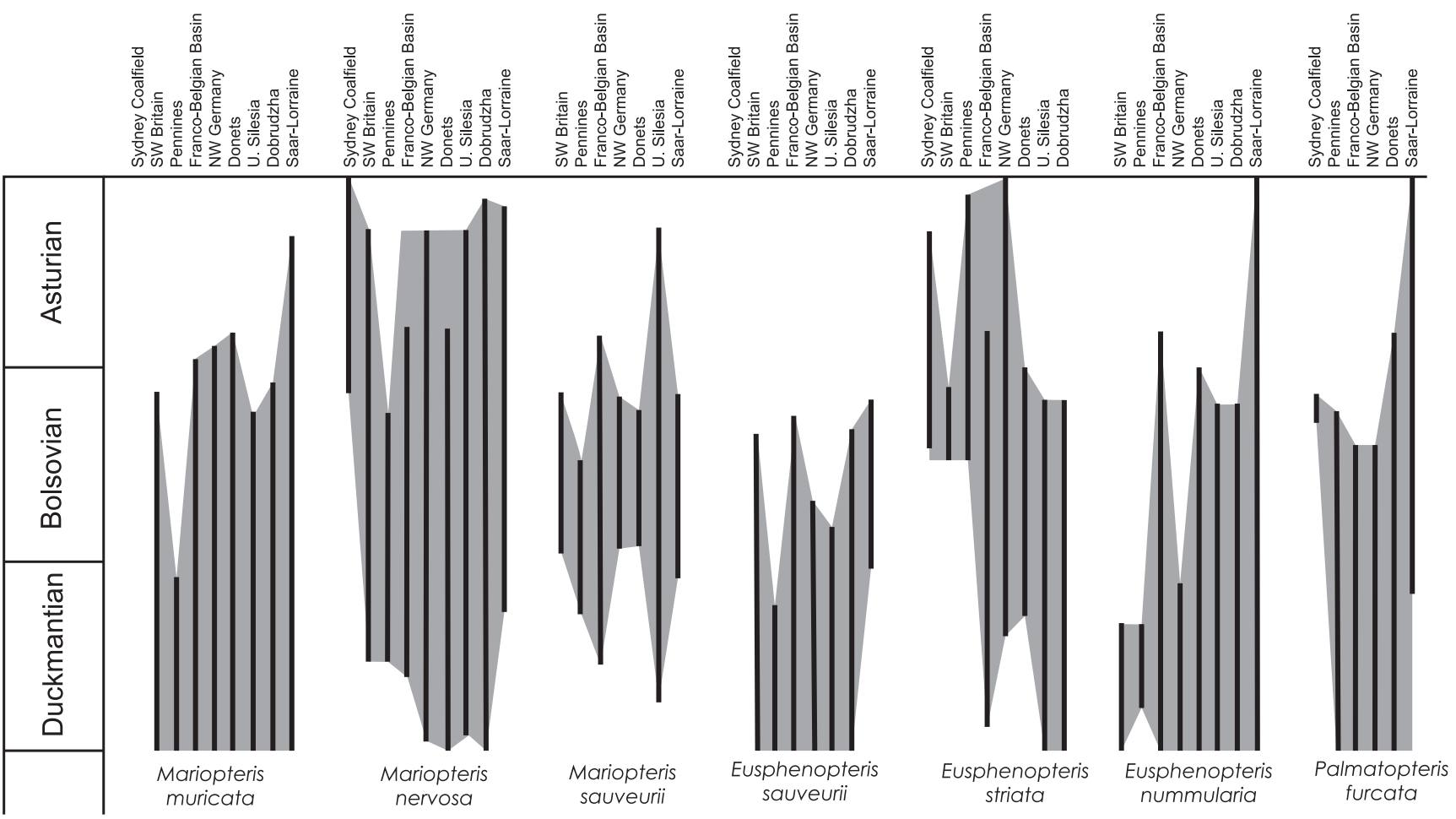

Fig. 35. Stratigraphical ranges of ten of the most widespread lyginopteridalean species in the main coal basins of Variscan Euramerica. Data from same sources as in Fig. 34.

relatively consistent biogeographical pattern through the late Westphalian and early Stephanian part of the succession, with five main palaeofloristic regions: Rhine and Silesia Palaeoprovinces, representing the lowland and more marginal parts of the Variscan foreland, respectively; Saar-Lorraine and Central Bohemia Palaeoprovinces for the two main intramontane basin complexes; and the Iberia Palaeoprovince for northern Spain and Portugal. The lyginopteridaleans study revealed an essentially similar pattern for the Bolsovian
Substage, but the pattern appeared to breakdown at higher stratigraphical levels. It was suggested that this may have been a consequence of the loss of species diversity among the Lyginopteridales, as discussed above.

A third analysis has now been done, combining the datasets used in Cleal (2008d) and (2008e), plus evidence for the Callistophytales (the latter summarised in Table 9). Exactly the same approach was used: initial sorting of the basins according to the pattern revealed by an unconstrained seriation analysis,

Table 9. Biogeographical distribution for callistophytalean species in Variscan Euramerica. Data taken from the same sources as used in Cleal (2008c, 2008d). 1 =occurs in Paripteris linguaefolia Zone; 2 =occurs in Linopteris obliqua Zone; 3 =occurs in Lobatopteris vestita and/or Odontopteris cantabrica Zone.

\begin{tabular}{|c|c|c|c|c|}
\hline & $\begin{array}{l}\text { Dicksonites plueckenetii } \\
\text { (Sternberg) Sterzel }\end{array}$ & $\begin{array}{l}\text { Dicksonites potieri } \\
\text { (Zeiller) Bertrand }\end{array}$ & $\begin{array}{l}\text { Pseudomariopteris cordatoovata } \\
\text { (Weiss) Krings \& Kerp }\end{array}$ & $\begin{array}{l}\text { Pseudomariopteris corsinii } \\
\text { (Teixeira) Wagner }\end{array}$ \\
\hline Canadian Maritimes & 3,4 & & & \\
\hline SW Britain & 3 & & 4 & \\
\hline Pennines & & 1 & & \\
\hline Nord-Pas-de-Calais & & 1,2 & & \\
\hline NW Spain & 3,4 & 2 & 4 & 4 \\
\hline Portugal & 4 & & & \\
\hline Upper Silesia & 3 & & & \\
\hline Saar-Lorraine & 3 & 1 & & \\
\hline Central Bohemia & 3,4 & 1 & 4 & \\
\hline Intra Sudetic Basin & 3,4 & & 4 & \\
\hline Dobrudzha & 3,4 & & & \\
\hline
\end{tabular}



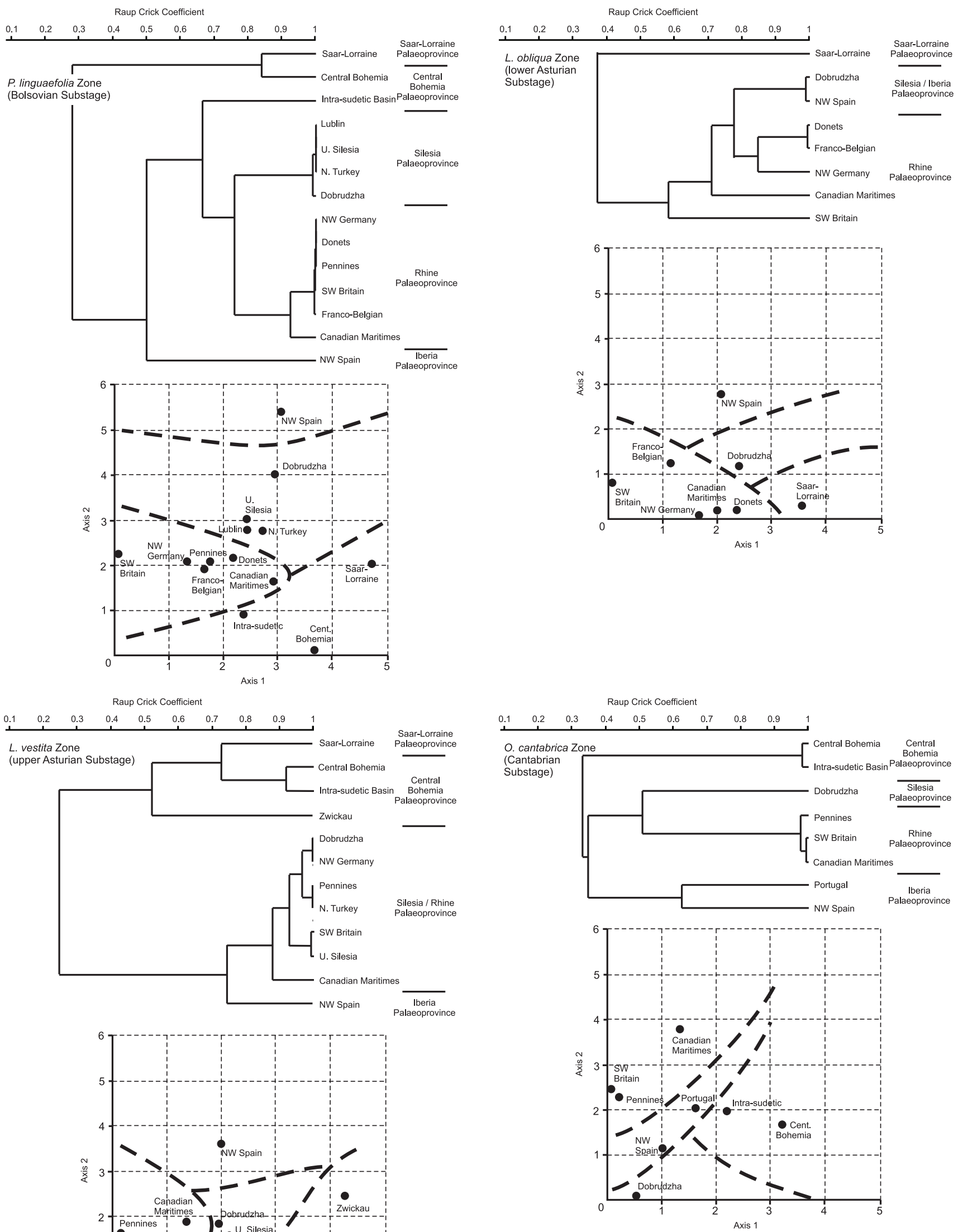

Fig. 36. Cluster analyses and Detrended Correspondence Analyses for the combined pteridosperm dataset for Variscan Euramerica (Medullosales, Lyginopteridales and Callistophytales). The data were taken from Cleal (2008c, 2008d) and Table 9. 
and then submitting those data to cluster analysis based on Raup-Crick Coefficients, and Detrended Correspondence Analysis (DCA) (see Cleal, 2008e for further details of the methods used). The results of the cluster analyses and DCA are shown in Fig. 36. Perhaps not surprisingly, the results for the $P$. linguaefolia Zone do not differ substantially from those obtained independently from the Medullosales and Lyginopteridales. The only notable discrepancy is that the Iberia Palaeoprovince (for this zone, this is restricted to NW Spain) already appears floristically distinct, whereas with the Medullosales it was merged with the Silesia Palaeoprovince.

The L. obliqua Zone results also agree generally with those obtained separately for the Medullosales and Lyginopteridales. The Saar-Lorraine remains clearly distinct, but the resolution of the other basins is poor, probably due at least in part to the smaller-number of floras available. The position of NW Spain in the cluster analysis appears anomalous, as it clusters closest with Dobrudzha. However, the DCA plot shows that, as in the preceding $P$. linguaefolia Zone, it separates out from the rest on Axis 2, thus helping justify its continued recognition as a distinct palaeoprovince.

For the L. vestita Zone, the cluster analysis of the combined data tends to be most similar to the results for the Lyginopteridales, with a poor separation of the Rhine and Silesia Palaeoprovinces. However, the DCA again separates out the Iberia Palaeoprovince through high scores on Axis 2, and the other basins show a progressive increase in scores on Axis 1 from lowland foreland basins (Rhine Palaeoprovince) to marginal foreland basins (Silesia Palaeoprovince) to intramontane basins.

In the 0 . cantabrica Zone, the medullosaleans comprise the vast majority of the pteridosperm species present, and so unsurprisingly the analyses of the combined dataset follow closely those of the Medullosales, with a clear separation of the Rhine, Silesia, Iberia and Central Bohemia Palaeoprovinces.

This floristic analysis of the combined dataset of all pteridosperms in Variscan Euramerica thus appears to confirm the essential consistency in biogeographical pattern through late Westphalian and early Stephanian times, with five distinct palaeoprovinces being recognisable throughout the succession (Fig. 37). There is no evidence of any notable break-down in the biogeographical pattern that might be expected if the area was being subjected to significant extrinsic stress such as climate change. As pointed out by Cleal (2008e) the number of basins where the wetlands were flourishing was progressively declining with time, probably due to changing drainage patterns across the region. Where the wetland habitats were able to survive, however, conditions appear to have remained favourable for at least the pteridosperm components of the vegetation, especially the Medullosales and probably the Callistophytales.

\section{Cordaitaleans (Z. Šimůnek)}

Cordaitaleans were an important Pennsylvanian coniferophyte group adapted to a range of habitats (Cridland, 1964; FalconLang, 2003), and included both large trees 20-40 m tall (Stewart \& Rothwell, 1993; Falcon-Lang \& Bashforth, 2004) and shrubs (Rothwell \& Warner, 1984). Some favoured peat-substrates and are preserved in coal balls (Costanza, 1984) whilst others grew on clastic-substrates and are preserved as silicified (petrified) wood (Falcon-Lang \& Bashforth, 2004) or in roof-shale assemblages. The individual parts of the arborescent cordaitaleans are often found separated and we mostly do not know which parts belonged together. Consequently, the different parts are classified as separate fossil taxa.
Fig. 37. Biogeographical pattern of pteridosperms across Variscan Euramerica during late Westphalian and early Stephanian times. Based on analyses shown in Fig. 36.

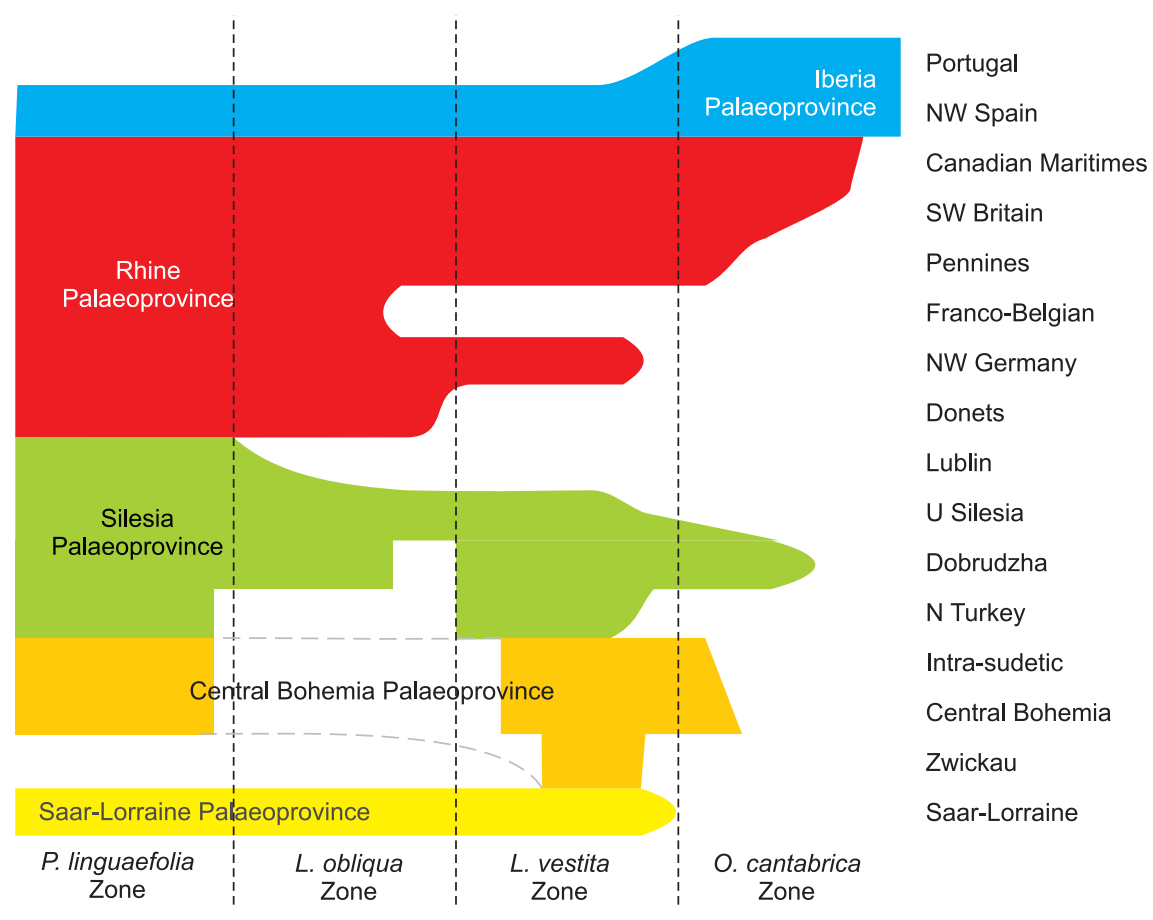


The problem with using fossil cordaitaleans for stratigraphical correlation is their identification. Most cordaitalean remains found in roof-shale floras are leaves, with stem imprints, pith casts and fructification much rarer. Leaves should, therefore, be the best for evaluating cordaitalean diversity and biostratigraphy, but their study is not easy. The classification of Cordaites species was traditionally based on leaf shape and venation. The leaves are usually lanceolate, 300-800 mm long and 40-150 $\mathrm{mm}$ wide, and so usually only fragments are found. The determination of such fragments is difficult as there is no information about the leaf apex. Some authors have emphasised the venation in determining cordaitalean leaves: for instance, Josten (1991) regarded Cordaites palmaeformis as having all veins of the same thickness, Cordaites borassifolius as having alternating 'thin' and 'thick' veins, and Cordaites principalis as having between two and seven 'thin' veins alternating with one 'thick' vein. However, taphonomy affects the venation (Crookall, 1970; Bashforth, 2005), and individual species often appear to show different veining patterns on the adaxial and abaxial sides of the leaf (Harms \& Leismann, 1961; Šimůnek, 2007b).

Cordaitalean cuticles started to be studied seriously in the 1960s (Barthel, 1962a, 1962b, 1964; Ledran, 1966; Rabitz, 1966), although usually as an appendix to the morphological description of the species. However, it was shown that individual morphological species (e.g. C. principalis) could have several types of cuticle and consequently could not represent one biological species. To solve the resulting taxonomic problems it is necessary to study the cuticles of the type material, and only specimens that have the same cuticular features can have the same name as the holotype. The study of cuticles from the type specimens is still in progress and so new names have had to be given to species determined by means of cuticles from the Bohemian Massif (Šimůnek, 2007b). The cuticles described by Ledran (1966) and Rabitz (1966) are difficult to compare with the Bohemian ones, because they are mostly poorly preserved and illustrated at low magnification. New material from Bulgaria (Tenchov), France (Laveine) and Germany have been obtained but have still not been fully studied and described.

There are about 33 validly published cordaitalean species that have been described over the last 150 years or so, based on morphology or, in case of coal balls, anatomy. Of the adpression species that have been described from Europe, only six occur in the Bolsovian to Cantabrian substages: Cordaites angulosostriatus Grand'Eury, C. borassifolius (Sternberg) Unger, C. principalis (Germar) Geinitz, C. palmaeformis (Göppert) Weiss, Dorycordaites zeilleri Ledran and Poacordaites microstachys Goldenberg (Zeiller). Only two species of pith casts are known. Fructifications are more diverse, but are very rare and only between one and five species of Moscovian age are known per country; they are therefore of little value for evaluating species diversity or biogeography.

Even though the taxonomy of the leaves is still imperfect, they are the most common cordaitalean fossils and thus have the most potential for palaeobiogeography. The leaves are common and occur in every Pennsylvanian-aged basin, but because of problems with their determination they are usually recorded simply as Cordaites sp. or Poa-Cordaites sp. Consequently, data from individual basins (Table 10) extracted from the Fossilium Catalogus $(70,71)$, which are based mainly on leaf morphology, are incomplete and do not reflect the natural diversity of this group. From Table 10 it is evident that leaves with the $C$. principalis and $C$. borassifolius type venation are most common, and the C. palmaeformis type venation is also relatively widespread. To determine $C$. angulosostriatus it is necessary to have a complete leaf, or at least the leaf-apex, which is typically broadly rounded. Dorycordaites zelleri, which was described by Ledran (1966) from France, is easily confused with $C$. principalis. Poacordaites microstachys is distinctive by way of its very narrow leaves and is difficult to confuse with any other Asturian species. All of these fossil-species have been reported in both the Bolsovian and Asturian substages, although the records of $P$. microstachys in Bolsovian strata are questionable (it is therefore marked in Table 10 with a question mark).

Figure 38 shows that the diversity of Bolsovian to Cantabrian cordaitalean leaf species based on morphology appears to be low, but that this is in marked contrast to the diversity determined from cuticles (e.g. Šimůnek, 2007b). The dashed line in Fig. 38 represents cordaitalean diversity in the Bohemian Massif based on cuticular evidence. The low diversity of cuticular species in the Stephanian of the Bohemian Massif is because

Table 10. Biogeographical distribution for Cordaites species in Variscan Euramerica.

\begin{tabular}{|c|c|c|c|}
\hline & Age & $\begin{array}{l}\text { Cordaitalean } \\
\text { cuticular } \\
\text { group }\end{array}$ & Species \\
\hline \multirow[t]{10}{*}{ Bohemia } & Bolsovian & $\mathrm{A}$ & C. tuchlovicensis, C. lubnensis \\
\hline & & B & C. rerichensis \\
\hline & & c & C. borassifolius, C. raconicensis \\
\hline & & D & C. kladnoensis, C. latus \\
\hline & & E & C. wartmannii, C. polynervus \\
\hline & Asturian & A & C. ledecensis \\
\hline & & B & $\begin{array}{l}\text { C. pilsensis, C. krasovicensis, } \\
\text { C. blazkovicensis }\end{array}$ \\
\hline & & C & C. dobranensis, C. wilkischensis, \\
\hline & & & C. touskovensis \\
\hline & Cantabrian & $\mathrm{D}$ & C. radcicensis \\
\hline \multirow[t]{2}{*}{ Dobrudzha } & Bolsovian & $\mathrm{B}$ & C. cf. idae, C. sp. \\
\hline & Asturian & $\mathrm{B}$ & C. cf. palmaeformis \\
\hline \multirow[t]{3}{*}{ France } & Bolsovian & B & C. gentilis \\
\hline & Asturian & B & C. 'borassifolius', C. gentilis, \\
\hline & & & C. imperialis \\
\hline \multirow[t]{4}{*}{ Germany } & Bolsovian & $\mathrm{A}$ & C. angulosostriatus \\
\hline & & $E$ & C. wartmannii \\
\hline & Asturian & B & Poa-Cordaites cf. microstachys \\
\hline & & E & C. cf. wartmannii \\
\hline
\end{tabular}




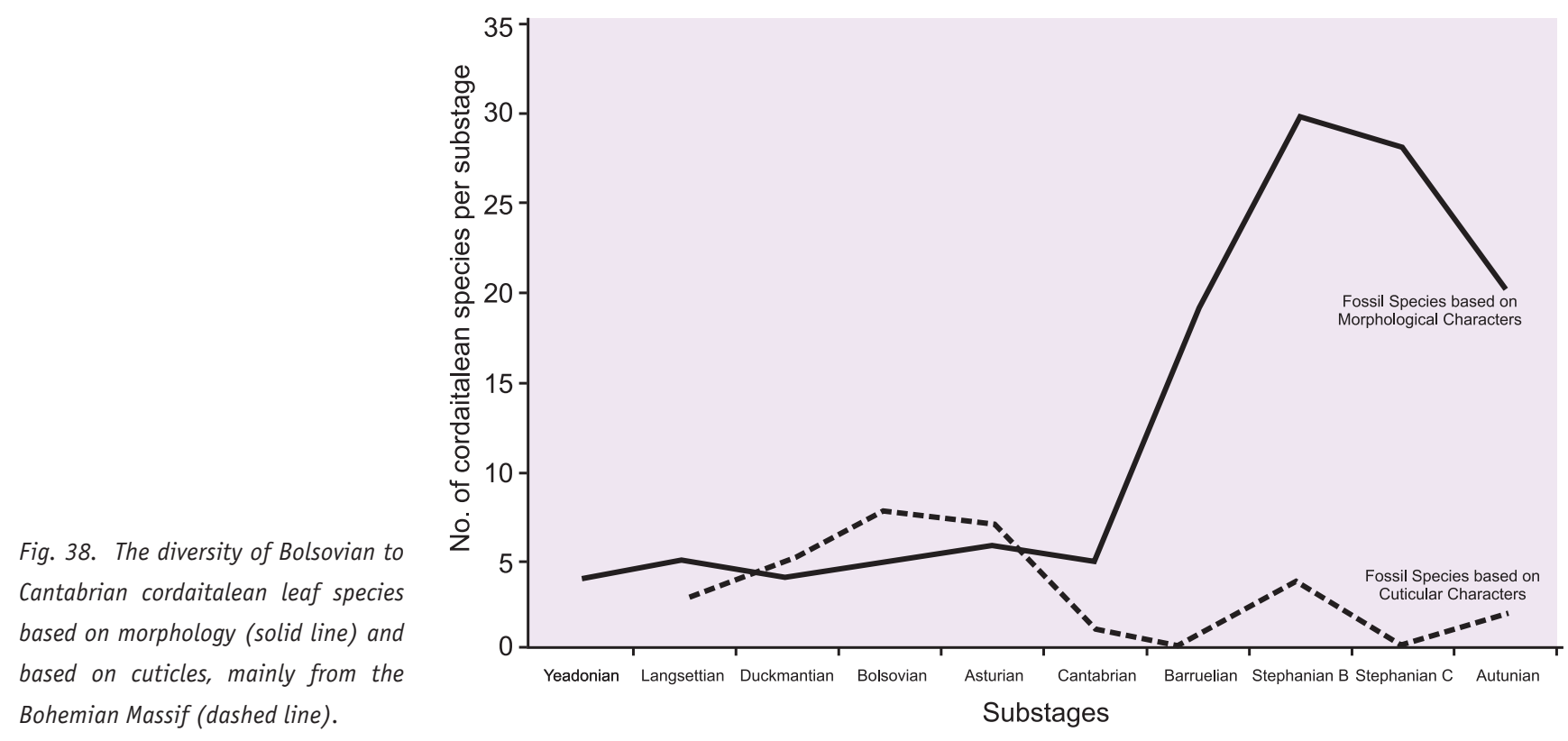

few samples have been studied up until now. In contrast, many species have been described from Stephanian and Autunian macrofloras, mainly in the French Massif Central by Grand'Eury (1877) and Ledran (1966). The following species have their holotypes in the Bolsovian-Cantabrian interval: $C$. borassifolius (Bolsovian, Czech Republic) and D. zeilleri (Bolsovian, northern France). P. microstachys comes from the Saar Basin, Germany (its precise stratigraphical position is not known). Cuticles of these species from their type regions have been studied, although those of $D$. zeilleri were very poorly preserved (Ledran, 1966).

Based on abaxial cuticles, five main cordaitalean groups of species can be distinguished (Fig. 39):

A. Stomata either dispersed, or in ill-defined stomatal rows (separated by ordinary epidermal cells).

B. Stomata in well-defined, simple or double stomatal rows. The neighbouring stomatal complexes usually touch, with lateral subsidiary cells and a polar subsidiary cell usually being shared by two neighbouring stomatal complexes.

C. Stomata in stomatiferous bands that are separated by nonstomatiferous bands. Each band consists of three to seven well-defined stomatal rows.

D. The stomatiferous and non-stomatiferous bands are formed of cells of different shapes. The stomata are not very prominent within the stomatiferous band.

E. Similar to the Group D, but with better-defined stomata within the stomatiferous bands, and the ordinary cells of stomatiferous and non-stomatiferous bands being similar in shape.

The Bolsovian and Asturian cordaitalean cuticles have been studied in most detail from the Bohemian Massif (Šimůnek, 2007b), with nine cuticular species have been determined in Bolsovian macrofloras and seven in Asturian macrofloras; only one cuticular species was recognised in Cantabrian strata
(Table 10). A comparison of these with species from other parts of Europe is difficult, because of the lack of evidence on the cuticles from these other areas.

\section{Dobrudzha Coalfield}

Only two species from the Dobrudzha Coalfield could be compared with already described species based on cuticles: a Bolsovian specimen resembles the Bohemian Cordaites idae, and an Asturian one is similar to Cordaites palmaeformis from the Duckmantian of Wałbrzych, Poland.

\section{Saar-Lorraine}

Cuticles described by Wartmann (1969) from the Bolsovian of the Saar Basin resemble those described as Cordaites wartmannii from the Bolsovian of Bohemia. Cuticles of two other species from the Saar Basin have been observed. Cuticles of Bolsovian Cordaites angulosostriatus are comparable with Cordaites sustae or C. strazkovicensis from the Langsettian and Duckmantian of the Czech Republic. The Asturian species Poacordaites microstachys, whose holotype originated from the Saar Basin, has yielded cuticles that appear to be different from any cuticles reported up until now.

The author (ZS) has also studied cordaitalean cuticles from Saar-Lorraine in the P. Bertrand Collection (Lille). Bertrand had assigned new names to some of these specimens (Cordaites imperialis, C. gentilis) but they were not formally described and are thus nomina nuda. Cuticles of both of these species resemble those of Cordaites schatzlarensis Šimůnek \& Libertín from the Duckmantian of the Intra Sudetic Basin, Czech Republic. Cuticles prepared from the Asturian Cordaites 'borassifolius' are quite different from those from type Cordaites borassifolius from Bohemia. 

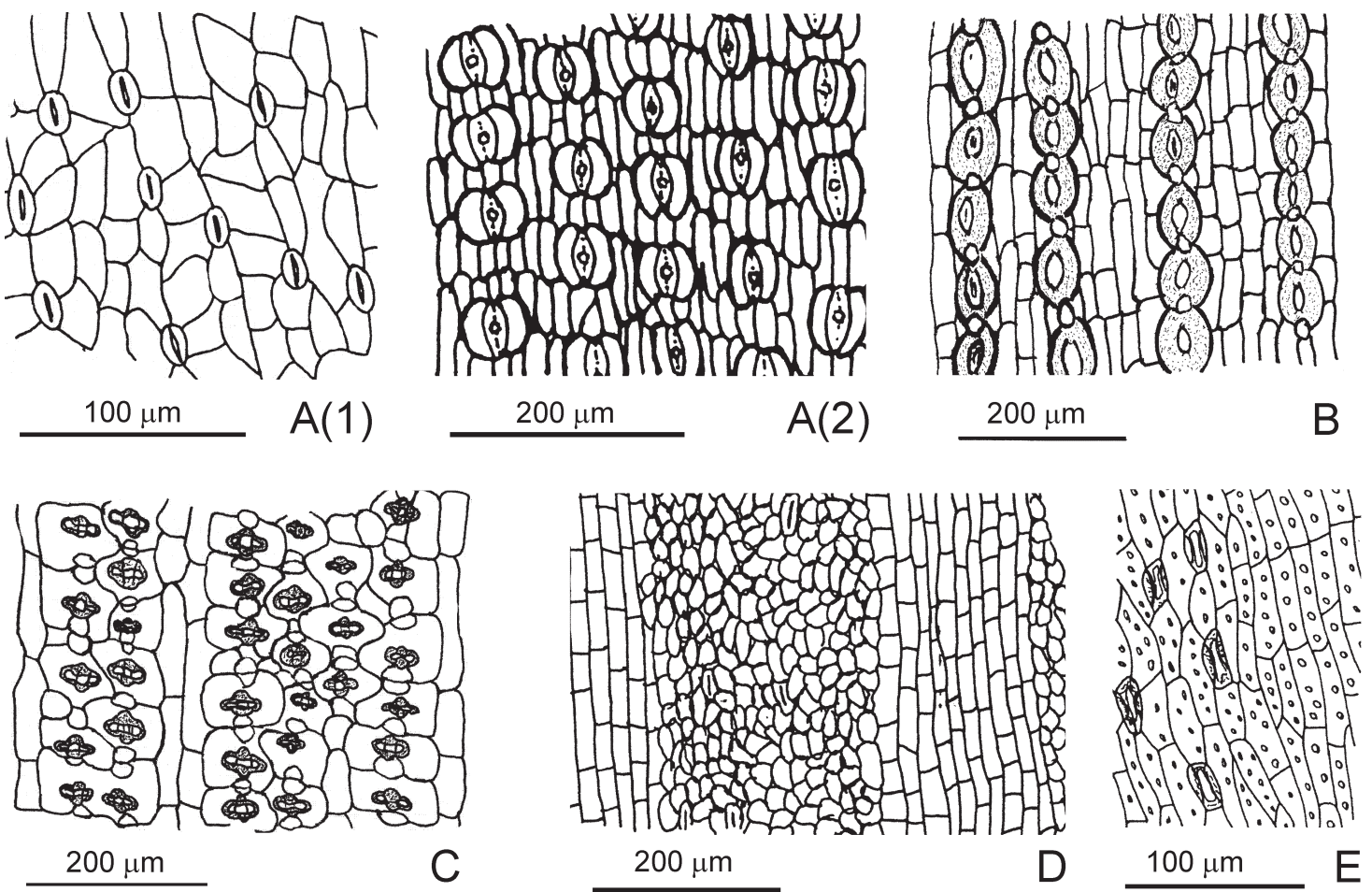

Fig. 39. Principal Bohemian cordaitalean cuticular groups: A(1) - Cordaites tuchlovicensis Šimůnek, Kladno-Rakovík Basin, Radnice Member, Bolsovian. A(2) Cordaites ledecensis Šimůnek, Kladno-Rakovík Basin, Nýrany Member, Asturian. B - Cordaites rerichensis Šimůnek, Kladno-Rakovík Basin, Radnice Member, Bolsovian. C - Cordaites borassifolius (Sternberg) Unger, Radnice Basin, Radnice Member, Bolsovian. D - Cordaites kladnoensis Šimůnek, KladnoRakovík Basin, Radnice Member, Bolsovian. E - Cordaites wartmannii Šimůnek Kladno-Rakovík Basin, Radnice Member, Bolsovian.

\section{Zwickau Basin}

The author (ZS) has seen cuticles from here that are similar to those of the Bolsovian Cordaites wartmannii from Bohemia.

\section{Cordaite biogeography}

The cordaitaleans were an advanced group in Late Pennsylvanian macrofloras. Their diversity (based on European foliage) was low in Namurian and Westphalian times, but increased rapidly in Stephanian times. Due to problems with determining leaf fragments, only two fossil species (Cordaites borassifolius and C. principalis) are present in all palaeoprovinces. Cordaites palmaeformis is less widespread; and Cordaites angulosostriatus and Poacordaites microstachys are very rare and restricted to SW Britain, Pennines and Saar-Lorraine. Dorycordaites zeilleri is a local species of Nord-Pas-de-Calais. Apart from these species, the cordaitalean fragments determined as Cordaites sp. are reported from all basins.

The taxonomic significance of the five distinct cuticular types recognised in European cordaitaleans is still not confirmed. Two leaf fossil genera can be usefully distinguished in the Euramerican Carboniferous - Cordaites Unger and PoaCordaites Grand'Eury ex Brongniart. The genus Dorycordaites Zeiller is superfluous as it cannot be distinguished from Cordaites in small leaf fragments. Pachycordaites Ledran was published without a diagnosis and so must be rejected. It seems that cordaitaleans were not affected by climate change or a reduction in wet habitats, as they were adapted to drier conditions. This may explain why their diversity increases in Stephanian macrofloras, especially in the French basins, and why indeterminate cordaitalean leaves are also widespread in red sediments.

\section{Biostratigraphy (C.J. Cleal)}

Macrofloral biostratigraphy is one of the most important means of correlating upper Westphalian and Stephanian terrestrial sequences and has consequently attracted considerable interest over the last century. Biostratigraphy moreover gives a picture of how vegetation was changing in an area with time and is thus a potentially useful tool in environmental studies.

Detailed studies on the distribution of the plant macrofossils in these rocks seem to suggest that there was a series of stepwise changes in the species composition, which is naturally expressed in a series of zones and subzones. The idea of using zones to express the changing pattern of vegetation through the Westphalian Stage was initiated by Zeiller (1894) and expanded by Bertrand $(1914,1919)$. However, these schemes essentially made the zones coincident with the lithostratigraphical divisions and were intended to express how those lithostratigraphical divisions could be recognized through their fossil content rather 
than reflecting the changing vegetation with time. The earliest attempt to establish zones purely on the ranges of the plant fossil species was by Dix (1934), based mainly on the South Wales Coalfield, although she also attempted to identify the zones in other European coalfields (see also Dix, 1937). Most notable was Dix's innovative use of bar charts to express the detailed distribution of the species, thereby making the biostratigraphical model independent of the lithostratigraphy (for more background to the development of Dix's idea, see Burek \& Cleal, 2005 and Fraser \& Cleal, 2007).

Alternative schemes were developed for the Canadian Maritimes coalfields by Bell (1938), for the Donets by Novik (1952) and for the United States by Read \& Mamay (1964), but these failed to find application outside of the areas in which they were initially developed. The first alternative scheme to Dix's that received widespread use was by Wagner (1984), who proposed 16 zones based on the macrofloras for the whole Carboniferous System. Like Dix, Wagner based his zones on species range charts, albeit composite range charts derived from data across large areas of Euramerica. However, Wagner's scheme differed from Dix's in a number of points, and some of the major changes in the succession of macrofloras recognised by Dix were not reflected in Wagner's scheme, especially changes in the middle Langsettian and middle Bolsovian stages. In an attempt to reconcile the two schemes, Cleal (1991b) and Cleal \& Thomas (1994) proposed to use Dix's scheme to recognized subzones within Wagner's zones. Although this means that some of the major changes in the macrofloras occur at subzonal rather than zonal boundaries, it has the merit that the widely used Wagner scheme is allowed to remain essentially intact.

The following summary will examine the evidence for the macrofloral zones and subzones from the upper Duckmantian through to the Cantabrian substages. This is partly to see what evidence there is to support stratigraphical correlation, but also to see what it shows about the changes that were taking place in the mainly clastic substrate vegetation of the coal swamps. The zones are essentially assemblage range zones and subzones, and so emphasis will be given to the biohorizons (sensu Cleal, 1999) where the major changes occur in the succession of macrofloras and which mark the boundaries between the zones and subzone.

\section{Base of Paripteris linguaefolia Zone}

This biohorizon usually occurs in the upper Duckmantian Substage, and is mainly marked by the appearance of Mariopteris nervosa (Brongniart) Zeiller and Macroneuropteris scheuchzeri (Hoffmann) Cleal et al., two species that become extremely abundant and widespread in the late Westphalian macrofloras of Euramerica. The appearance of pinnae of the Neuropteris obliqua (Brongniart) Zeiller complex with pseudoanastomosed veins, and usually referred to as Neuropteris semireticulata Josten, also make their first appearance at about this level. It seems to correspond with the base of Dix's (1934) Zone F; she placed it a little higher in the South Wales sequence, at about the Aegiranum Marine Band, but she had little data from the beds immediately below that marine band and she specifically associated the change in the macrofloras with the appearance of marine influence in what today is termed the upper Duckmantian Substage.

The biohorizon can be easily identified in the British coalfields, at or just below the first of the upper Duckmantian marine bands (Fig. 40; see also Cleal, 2005, 2007, 2008c). In the Ruhr Coalfield it also occurs at about the level of the lowest upper Duckmantian marine band, in the lower Horst Formation (Fig. 40), and in the Nord-Pas-de-Calais Coalfield at or just below the base of the Pouilleuse Formation (Laveine, 1987).

In areas where there is little or no marine influence, however, the biohorizon is more difficult to locate. In Saar-Lorraine, the base of the zone probably occurs in the poorly fossiliferous St. Ingbert Formation or maybe the hiatus below it (Fig. 40). In Western and Central Bohemia, the Radnice Member clearly belongs to the $P$. linguaefolia Zone as indicated by the presence of $M$. scheuchzeri and $M$. nervosa throughout the interval (Šimůnek in Holub et al., 2001). In the Dobrudzha Coalfield it probably occurs within the hiatus below the Vranino Formation, although the palaeobotanical record of that formation is generally poor. In the Upper Silesia, Lublin and Intra Sudetic coal basins the situation is very problematic as at least three of the species that elsewhere tend not to occur below the $P$. linguaefolia Zone range are here ranging down into strata interpreted as earliest Duckmantian or even Langsettian age (Kotasowa, 1979; Migier, 1980; Zdanowski \& Żakowa, 1995; Šimůnek in Holub et al., 2001).

\section{Base of Laveineopteris rarinervis Subzone}

The upper part of Wagner's (1984) P. linguaefolia Zone appears to be biostratigraphically distinct, at least in the basins of the western part of the Variscan foreland, and corresponds to Dix's (1934) Zone G and the L. rarinervis Subzone of Cleal (1991b) and Cleal \& Thomas (1994). The base of the subzone is marked by the appearance of $L$. rarinervis (Bunbury) Cleal et al., Annularia sphenophylloides (Zenker) Gutbier and Annularia spinulosa Sternberg (= Annularia stellata auct. - see Barthel, 2004); also by the marked increase in abundance of Eusphenopteris striata (Gothan) Novik, although this species can occur rarely at lower horizons.

The biohorizon at the base of the subzone is readily identifiable in the western coalfields of the Variscan foreland, in Britain and the Ruhr (Fig. 40). In Nord-Pas-de-Calais it probably occurs in the middle Six-Sillons Formation, although the two Annularia species seem to range here to slightly lower horizons (Laveine, 1987). In the Sydney Coalfield, the subzone is probably present in the South Bar Formation, where Eusphenopteris striata and Annularia sphenophylloides have been recorded 

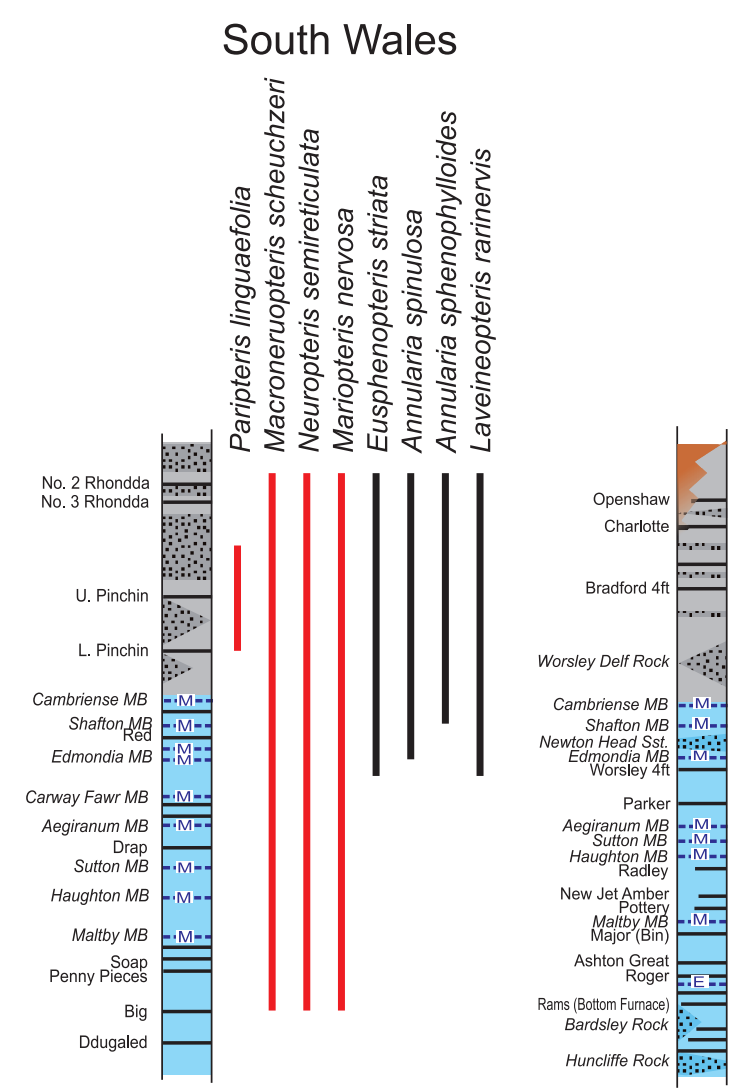

Upper Silesia
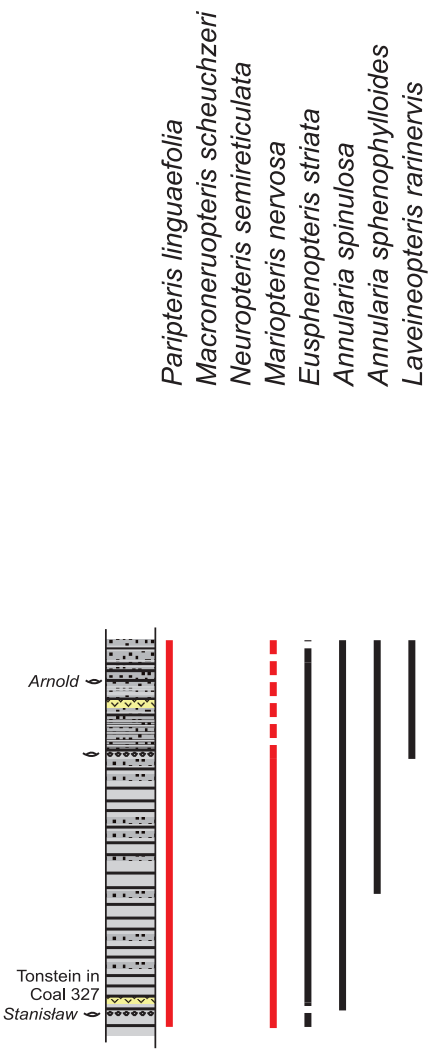

Pennines
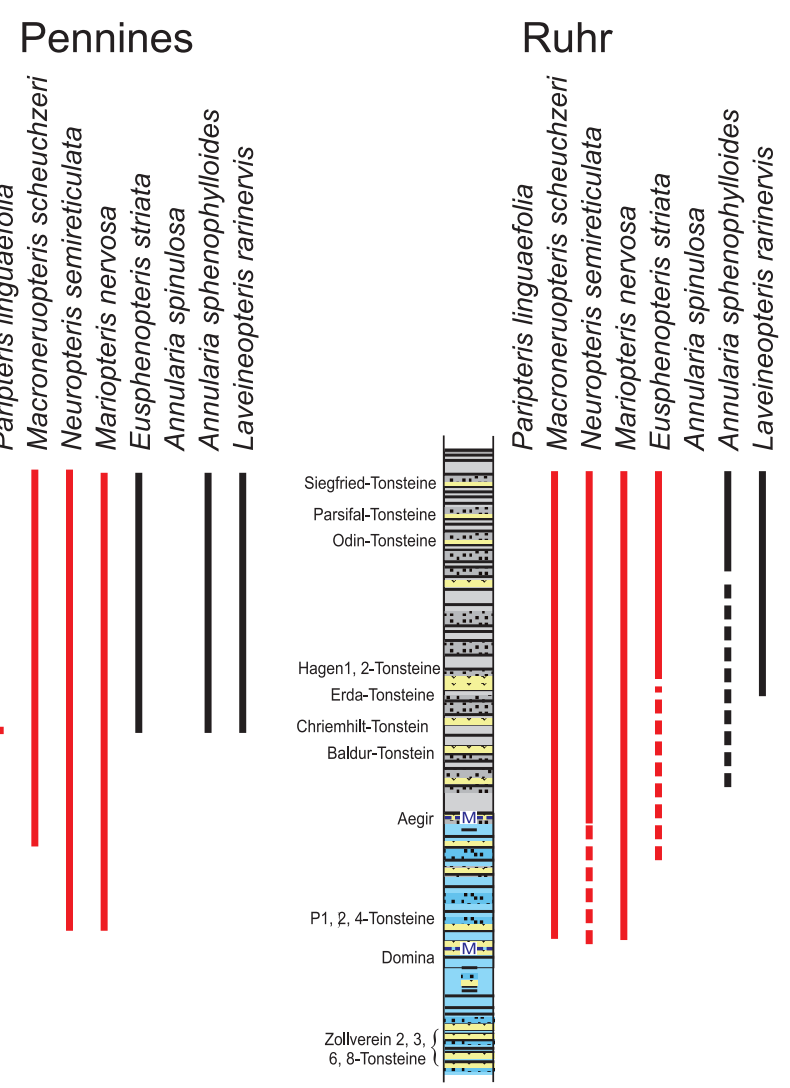

Saar-Lorraine
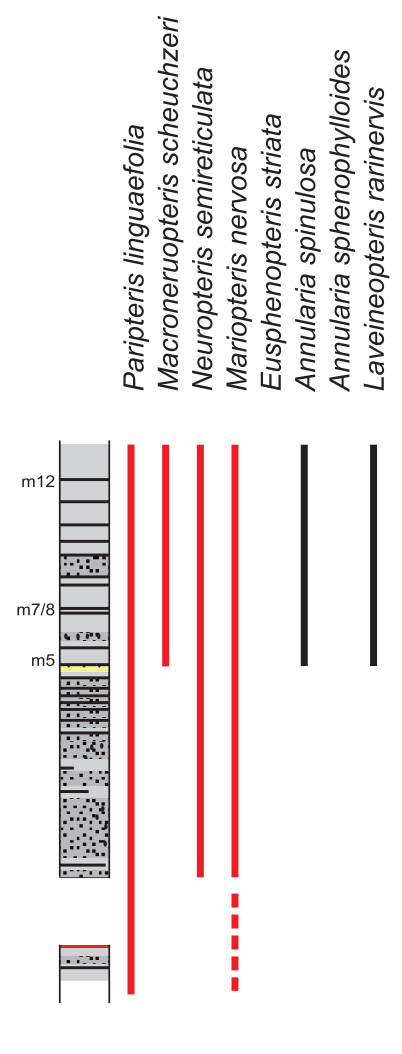
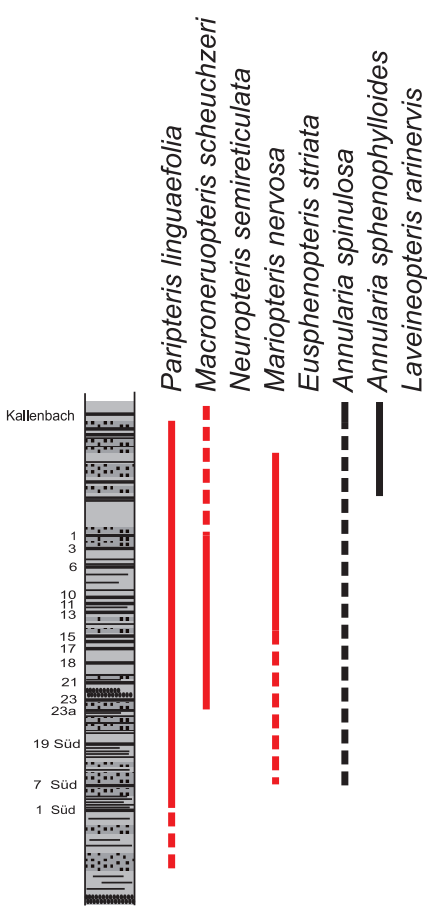

Fig. 40. Stratigraphical ranges of index taxa for the Paripteris linguaefolia Zone (macrofloras) in six coal basins in Variscan Euramerica. The species used to identify the base of the zone are shown in red, those used to identify the base of the L. rarinervis Subzone in black. Based on Cleal (2005, 2007, 2008b), Josten (1991), Zdanowski \& Żakowa (1995), Cleal et al. (2004), Laveine (1989) and Cleal (personal observations on Saarland floras). 
(Bell, 1938), but the macrofloras of these stratigraphically lower horizons in this coalfield have not been well documented; the suggestion by Bell (1938) that these lower beds were of Duckmantian age was discussed by Zodrow \& Cleal (1998) and shown to be in error.

In the entirely non-marine basins the subzone is difficult to distinguish from the underlying Neuropteris semireticulata Subzone. One of the key taxa, L. rarinervis, is absent from Western and Central Bohemia, and Saar-Lorraine (for discussions on the taxonomic confusion surrounding this and the stratigraphically-older Laveineopteris nicolausiana (Gothan) Cleal \& Shute see Cleal \& Shute, 1995, 2003). In the former area, the two Annularia species appear first in the upper part of the Radnice Member, suggesting that the base of the subzone may be at about this level. In the Saar-Lorraine, however, these species occur first in the Geisheck Formation, which would seem significantly later than in the lowland basins.

In Upper Silesia, A. stellata and Eusphenopteris striata range down to the uppermost Załęze Beds (upper Langsettian), appearing at about the same level as Mariopteris nervosa, whilst A. sphenophylloides appears just a short distance above this, in the middle Orzese Beds (middle Duckmantian) (Fig. 40; Kotasowa, 1979; Zdanowski \& Żakowa, 1995). L. rarinervis then appears in the lower Cracow Sandstone Series, at a level interpreted as near the base of the Bolsovian Substage. All these events would seem to be at levels much lower stratigraphically than the equivalent biohorizons in the lowland basins of western Europe.

In Lublin, L. rarinervis and A. sphenophylloides both appear in the upper Lublin Formation, at a level interpreted as the base of the Bolsovian Substage (Migier, 1980; Zdanowski \& Żakowa, 1995). In the Intra Sudetic Basin, A. sphenophylloides appears first at the base of the Petrovice Member and $L$. rarinervis a short distance above (Šimůnek in Holub et al., 2001), although the base of this unit is at least in some parts of the basin a non-sequence.

\section{Base of Linopteris obliqua Zone}

In most areas this zone is marked by the appearance of Neuropteris ovata Hoffmann and is taken as an index to the base of the Asturian ('Westphalian D') Substage. Bertrand $(1926,1937)$ recognised it as the 'Zone à Mixoneura' (Mixoneura was incorrectly believed to be the correct generic name for the $N$. ovata group of species) and for many years this became inextricably linked with the concept of a 'Westphalian D' stage (for a review, see Laveine, 1977).

Relying on a single taxon to identify a biostratigraphical level (and by inference a chronostratigraphical boundary) has obvious weaknesses. The most profound insights into this problem were provided by Laveine (1977) who proposed that the appearance of $N$. ovata should be seen in the context of the broader changes taking place in the macrofloras at about this stratigraphical level. He identified a number of 'events' (biohorizons) related to both the macrofloras and palynofloras (i.e. the appearances or disappearances of taxa, or the limits of their acmes) that normally seem to occur immediately below the appearance of $N$. ovata; only if these contextual biohorizons can also be recognised should the first occurrence of $N$. ovata be used to position the base of what we now call the L. obliqua Zone, and thereby the base of the 'Westphalian $D^{\prime}$ (Asturian) Substage. Laveine (1977) tested this model in the Lorraine, Nord-Pas-de-Calais and Sydney coalfields. Subsequently, it was also tested in the Central Asturian, South Wales, Saarland, Sydney and Dobrudzha coalfields (Cleal, 1978, 1984a, 1984b; Zodrow \& Cleal, 1985; Wagner \& Alvarez-Vázquez, 1991; Cleal et al. 2004). As a result, it now seems that the changes in the macro- and palynofloras in the upper Bolsovian and basal Asturian substages may be summarised as follows.

1. The disappearance of Pecopteris pennaeformis, the top of the acme of Cingulizonates loricatus, the appearance of Annularia stellata, and the start of the acme of Torispora securis. This in effect corresponds to the base of the L. rarinervis Subzone in the macrofloras.

2. The disappearance of Paripteris spp., and the appearances of Linopteris obliqua and Thymospora spp.

3. The appearance of Neuropteris ovata Hoffmann and/or Neuropteris flexuosa Sternberg.

In many of the areas dealt with in this study the base of the zone cannot be located as it occurs within a stratigraphical hiatus related to the Leonian tectonic phase (Pennines, southern North Sea, Forest of Dean, Upper Silesia, Intra Sudetic Basin, Central and Western Bohemia, Zwickau-Oelsnitz). In Lublin-Volhynia, the upper part of the succession may edge into the Asturian Substage (Zdanowski \& Żakowa, 1995) but the macrofloras from the highest beds are not diverse and the biostratigraphical evidence is equivocal. However, in those areas where it has been identified, the ranges of the key index taxa (both macrofloral and palynological) are summarised in Fig. 41. Although there are some divergences from the idealised model, on the whole the pattern is fairly consistent in the different basins. This may suggest that the changes are the response to some extrinsic factors such as climate, which would affect both lowland and more elevated basins. On the other hand, where we have detailed evidence of species diversities through this part of the succession, notably in the lowland South Wales basin (Cleal, 2007) and the intramontane SaarLorraine Basin (Uhl \& Cleal, in press), no major change in the diversities is evident. Rather, the Laveine model appears to be reflecting relatively subtle intrinsic changes in the vegetation at this time. 
Sydney Coalfield

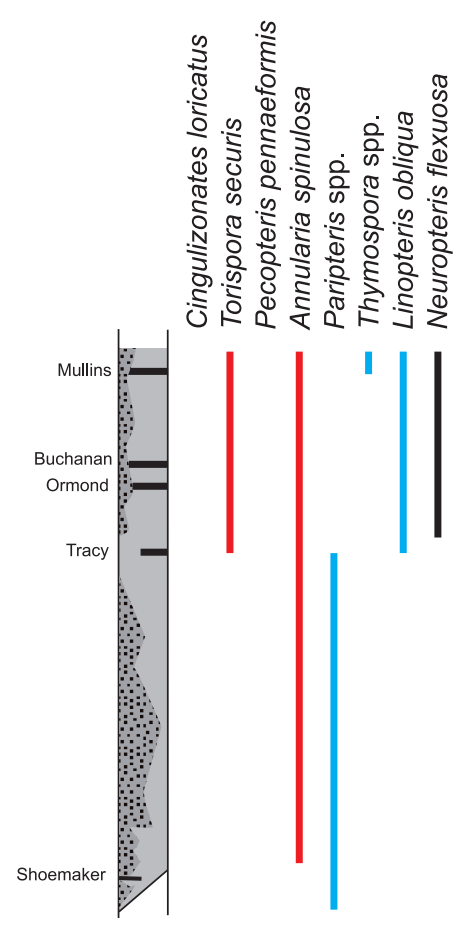

South Wales
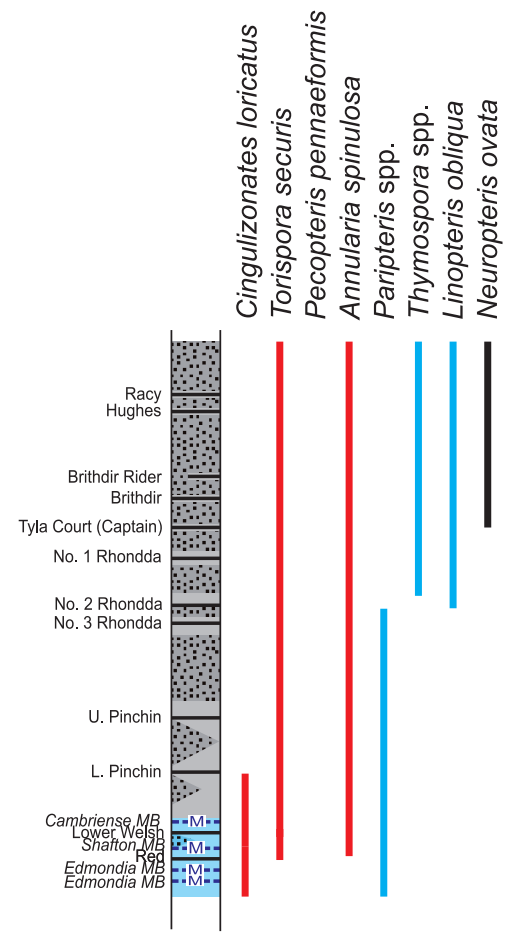

Ruhr

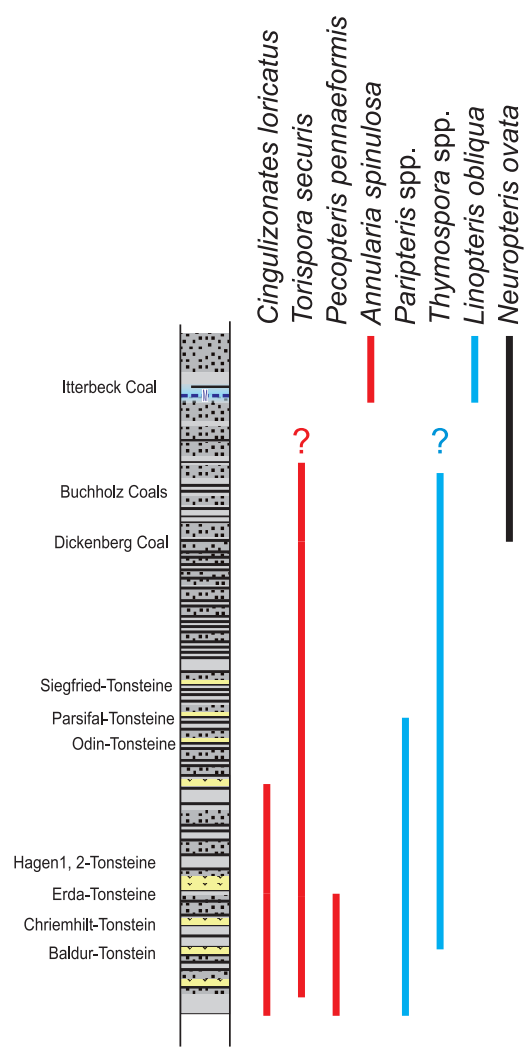

Dobrudzha

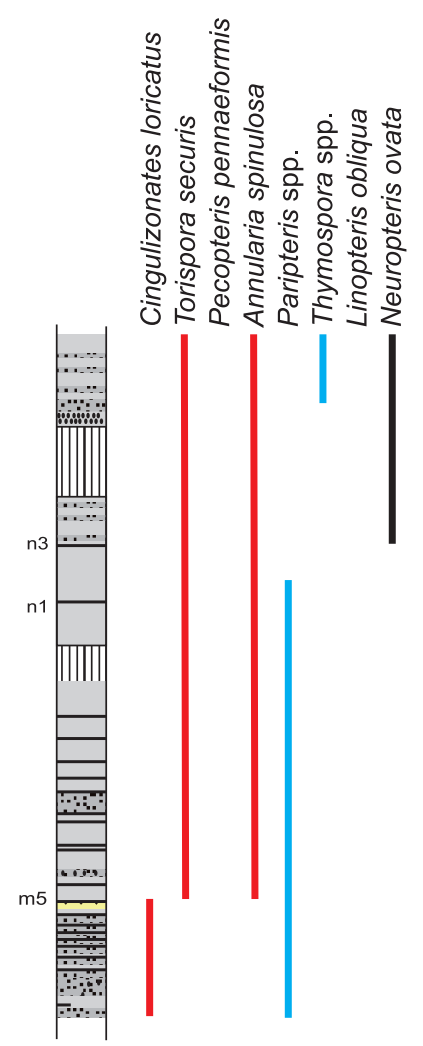

Fig. 41. Stratigraphical ranges of index taxa for the base of the Linopteris obliqua Zone in five basins in Variscan Euramerica. The taxa used to identifiy the three biohorizons are shown red, blue and black. Based on Grebe (1972), Laveine (1977), Cleal (1977, 1984a, 1984b, 2007), Josten \& Laveine (1984), Zodrow \& Cleal (1985), Josten (1991), Dimitrova (1997), Josten \& van Amerom (1999), Cleal et al. (2004) and Hartkopf-Fröder (2005). 


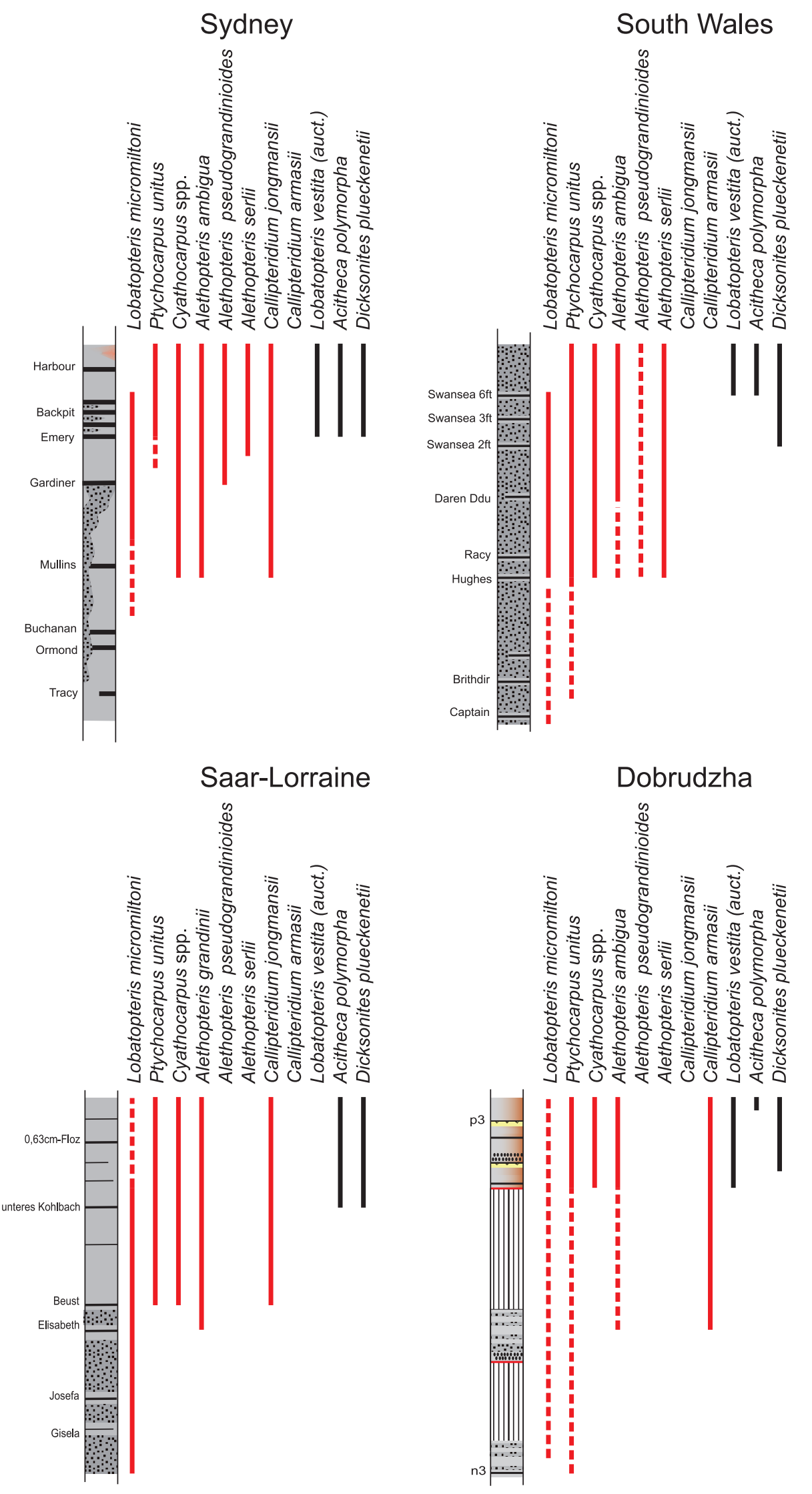

Fig. 42. Stratigraphical ranges of index taxa for the Lobatopteris vestita Zone (macrofloras) in four coal basins in Variscan Euramerica. The species used to identify the base of the zone are shown in red, those used to identify the base of the D. plueckenetii Subzone in black. Based on Cleal (1977, 1984a, 2007), Zodrow \& Cleal (1985) and Cleal et al. $(2004,2007)$. 
In contrast to the changes observed in the previous biohorizon, a far more significant shift in the adpression floras can be seen in the middle Asturian Substage. This level sees a substantial increase in the biomass of medullosaleans (notably alethopterids) and marattialean ferns in the clastic substrate vegetation (Cleal, 2007). In addition, several taxa make their first appearance here, notably Alethopteris ambigua Lesquereux, Alethopteris pseudograndinioides Zodrow \& Cleal, Alethopteris serlii (Brongniart) Göppert, Callipteridium jongmansii (Bertrand) Wagner and Callipteridium armasii (Zeiller) Wagner, whilst the marattialeans Lobatopteris micromiltoni (Bertrand) Wagner, Ptychocarpus unitus (Brongniart) Weiss and Cyathocarpus spp. undergo a substantial increase in abundance (in effect, in most places these three taxa appear first at this level).

As with the previous biohorizon, this level is not recognisable in many areas, due either to a hiatus caused by Leonian tectonic activity (Bristol-Somerset, Pennines, southern North Sea, Limburg, Intra Sudetic, Zwickau, Western and Central Bohemian Basin), these beds being in poorly fossiliferous red-beds (Ruhr) or these beds having been removed by early Stephanian erosion (Lublin). Nevertheless, within the study area, the biohorizon can be identified in the Sydney, South Wales, Saar-Lorraine and Dobrudzha successions (Fig. 42).

In all four basins, there is a reasonable consistency with which these species appear at near the same level. There are some exceptions, notably in the Sydney Coalfield, where the key part of the succession is relatively poor in macrofloras, and in the Dobrudzha Coalfield, where stratigraphical hiatuses complicate the picture. There are also some taxonomic complications; for instance Alethopteris grandinii (Brongniart) Göppert in Saar-Lorraine may be a local equivalent to A. ambigua (see comments by Zodrow \& Cleal, 1998). But if these complications are taken into account, the consistency with which this change in the macrofloras can be seen across Variscan Euramerica is remarkable (Cleal et al., 2007). The vegetation change reflected by this zonal boundary is of similar age to the Leonian tectonic phase that seems to have had such a profound impact on the distribution of the coal swamps. However, the change in the macrofloras occurs in areas such as the Saar-Lorraine where there is little evidence of this tectonic activity, which suggests that the two events may not be directly linked. The geographical spread of evidence of the macrofloral change may alternatively suggest that climate was a significant factor, and it is notable that these changes in the adpression floras are similar to the observed changes in the coal ball floras that have been interpreted as being caused by climatic change. This will be discussed further at the end of the present report.
Dix (1934) had also identified a change in the macrofloras in the middle-upper Asturian Substage, which she termed Zone I. Although not as marked as the change at the base of the $L$. vestita Zone, it is nevertheless widely recognisable (Cleal, 1978, 1984a, 1997, 2007; Zodrow \& Cleal, 1985; Wagner \& AlvarezVázquez, 1991; Cleal et al., 2007). The change, which involves the first appearance of Lobatopteris vestita auct. (see Pšenička et al., 2009 for a discussion of the nomenclature of this species), Acitheca polymorpha (Brongniart) Schimper and Dicksonites plueckenetii (Sternberg) Sterzel, has been identified in the Sydney, South Wales, Saar-Lorraine and Dobrudzha coalfields (Fig. 42). D. plueckenetii is particular significant as its distinctive pollen (Vesicaspora) is easily recognisable in the dispersed palynological record and so provides an important means of relating the macrofloral and palynological biostratigraphies. $D$. plueckenetii Subzone macrofloras are also known from the Zwickau (Schneider \& Rößler, 1996; Schultka \& Kahlert, in press) and Western and Central Bohemia coalfields (Wagner, 1977; Šimůnek in Pešek, 2004), as well as northern Spain (Wagner et al., 1983; Wagner \& Alvarez-Vázquez, 1991).

Much of what was said about the possible cause of the vegetation change reflected by the base of the L. vestita Zone also applies to this biohorizon.

\section{Base of Odontopteris cantabrica Zone}

This is the stratigraphically highest biohorizon that can be recognised in the Moscovian-age macrofloras of Variscan Euramerica. Although not as marked a change as that at the base of the L. vestita Zone, it is of considerable stratigraphical significance as it is used as an index to the base of the Stephanian Stage. In the type area for the WestphalianStephanian boundary, in northern Spain, the biohorizon is relatively easy to identify (Wagner et al., 1983). Elsewhere, it has proved more problematic as it does not represent such a marked change in the macrofloras as, for instance, the base of the L. vestita Zone. Nevertheless, by using the series of biohorizons identified by Wagner (in Wagner et al., 1983) immediately above and below the boundary it has proved possible to locate the boundary in at least four coalfields dealt with in this study (Fig. 43). Moreover, palynological criteria have also now been found that can supplement the macrofloral evidence for placing the stage boundary (Cleal et al., 2003).

In the context of this report, Biohorizons 2 and 3 are the most significant; Biohorizon 1 is too weakly expressed to be identified in any of the coalfields surveyed. Biohorizon 2 is marked mainly by a change in pinnule shape and venation within Alethopteris pseudograndinioides Zodrow \& Cleal, from that of the type variety to that of the var. subzeilleri (Wagner). This is part of a trend in this species that affected the ovules and pollen organs, as well as the foliage (Cleal et al., in press), and which seems to 
Sydney

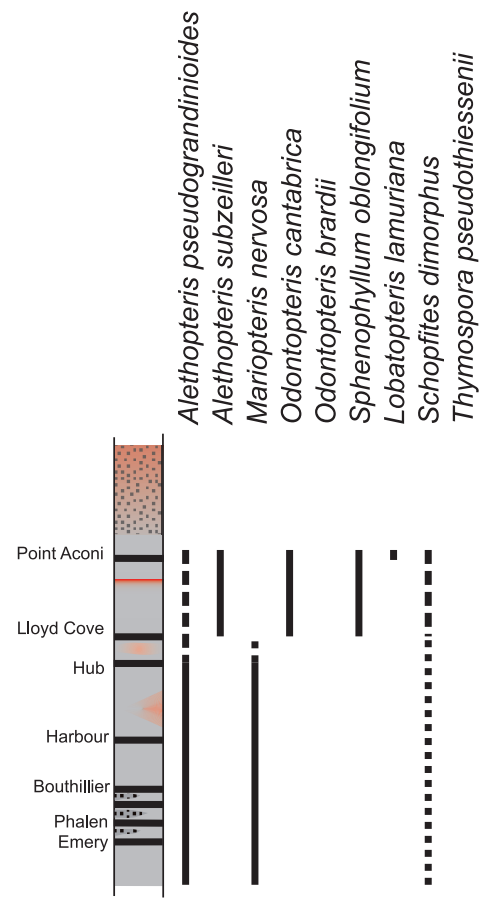

Fig. 43. Stratigraphical ranges of index taxa for the base of the Odontopteris cantabrica Zone in four basins in Variscan Euramerica. For succinctness in the chart, 'A. pseudograndinioides' only refers to the type variety of that species, whereas the var. subzeilleri is referred to as 'A. subzeilleri'. Based largely on data in Cleal et al. (2003), plus supplementary data from Valterova and Šimůnek (in Pešek et al., 2001).
South Wales

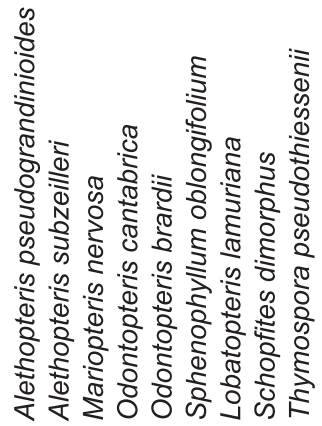

Forest of Dean and Oxfordshire
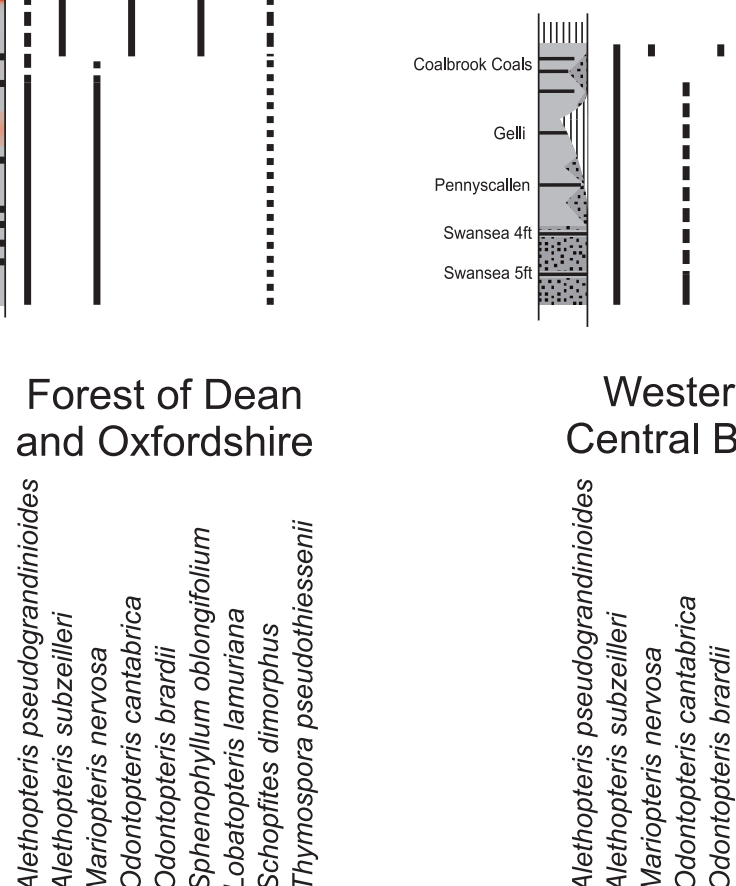

Western and Central Bohemia
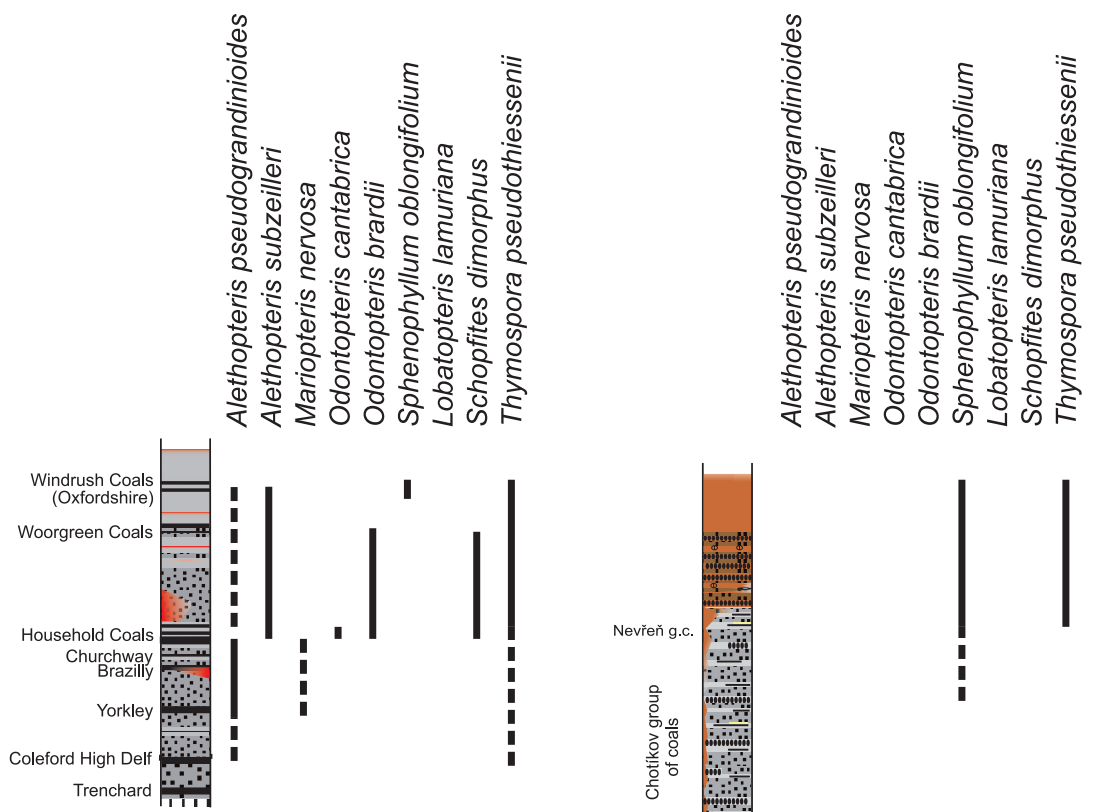

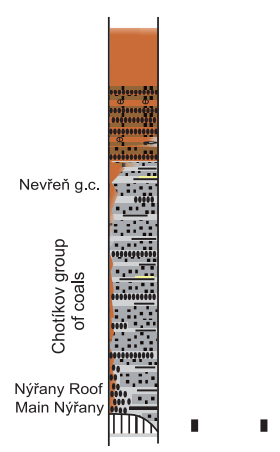

have undergone a distinct step-wise change in the uppermost Asturian Substage. Mariopteris also usually undergoes a distinct decline in abundance at this level. This is the level that occurs very close to the Westphalian-Stephanian boundary, and can be identified at about the Hub Seam in the Sydney Coalfield, the base of the Grovesend Formation in South Wales and the lower Household Coals interval in the Forest of Dean.
A short distance above, Biohorizon 3 sees the appearance of a number of species of typically Stephanian character: Odontopteris cantabrica Wagner, Odontopteris brardii (Brongniart) Brongniart, Lobatopteris lamuriana (Heer) Wagner and Sphenophyllum oblongifolium (Germar \& Kaulfuss) Germar. This change in the macrofloras can be seen at the Lloyd Cove Seam in the Sydney Basin, the Coalbrook Coals in South Wales, 
the upper Household Coals interval (especially at the Twenty Inch Rider Seam) in the Forest of Dean, and the upper Nýryany Member (the Nevřen Coal Group) in Western and central Bohemia. In northern Spain, Alethopteris bohemica Franke, Alethopteris barruelensis Wagner and Alethopteris zeilleri Ragot also first appear at about this level, but these taxa have not been reported at similar levels in the basins covered in this study.

At about the same level, the spores Schopfites often first appear (although they may also sometimes occur rarely at lower levels) together with a marked increase in abundance of Thymospora spores with coarser ornamentation ( $T$. pseudothiessenii (Kosanke) Alpern \& Doubinger). The significance of the latter change in the palynofloras has been queried by Streel et al. (2008) as they did not regard this species as being sufficiently different to justify a taxonomic distinction from Thymospora obscura (Kosanke) Wilson \& Venkatachala, which has a well-documented epibole starting in the middle Asturian Substage (corresponding to the base of the L. vestita Zone in the macrofloras). As pointed out by Cleal et al. (2003), however, in most of the basins where it has been possible compare in detail the ranges of the macrofloral and palynological species (e.g. Forest of Dean, Oxfordshire, Western and Central Bohemia, Illinois) there seems to be a coincidence between the macrofloral species of the lower Cantabrian Biohorizon 3 and the base of a T. pseudothiessenii epibole. Thus, confusing the latter lower Cantabrian event with the middle Asturian epibole of T. obscura (an index to the base of the palynological OT Zone of Clayton, 1977) could lead to miscorrelations.

Biohorizon 4 as outlined by Wagner (in Wagner et al., 1983) and Cleal et al. (2003), involving the first appearances of
Alethopteris leonensis Wagner and Callipteridium striatum Wagner, has not been identified in any of the basins covered in this study.

0 . cantabrica Zone floras macrofloras are known from the Sydney Coalfield (Zodrow, 1985; Cleal et al., 2007, in press), South Wales (Cleal, 1978, 1997, 2007), Forest of Dean and Oxfordshire (Wagner \& Spinner, 1972, 1997), the Svatoňovice coal group of the Intra Sudetic Coalfield (Wagner, 1977; Šimůnek in Pešek, 2004), the upper Nýřany Member in central and western Bohemia (Wagner, 1977; Šimůnek in Pešek, 2004) and the Dobrudzha Coalfield (Cleal et al., 2004), as well as in its type area in northern Spain (Wagner et al., 1983).

\section{Insects (E. Jarzembowski, J. Prokop \& J. Schneider)}

Pennsylvanian times were important entomologically because they provide evidence of the first adaptive radiation of the winged insects (pterygotes; Jarzembowski, 2003). These are the dominant group of insects comprising some $99 \%$ of all known insect species and the majority of life on Earth (Jarzembowski, 2005a). The Carboniferous radiation included insects which could fold their wings utilising a hinge mechanism (Neoptera) as well as those which could only bend the wings (Palaeoptera). Pennsylvanian Neoptera are mainly Polyneoptera comprising the blattodean-orthopteran orders (insects allied to modern cockroaches, rock crawlers and grasshoppers) as well as stem group (ancestral) insects loosely referred to as 'Protorthoptera' (Jarzembowski, 2001a; Prokop \& Nel, 2007). Unlike the present day, the Carboniferous evidence for advanced insects with complete metamorphosis (Oligoneoptera) is, however, scarce (Prokop, Nel \& Hoch, 2005). Carboniferous Palaeoptera are

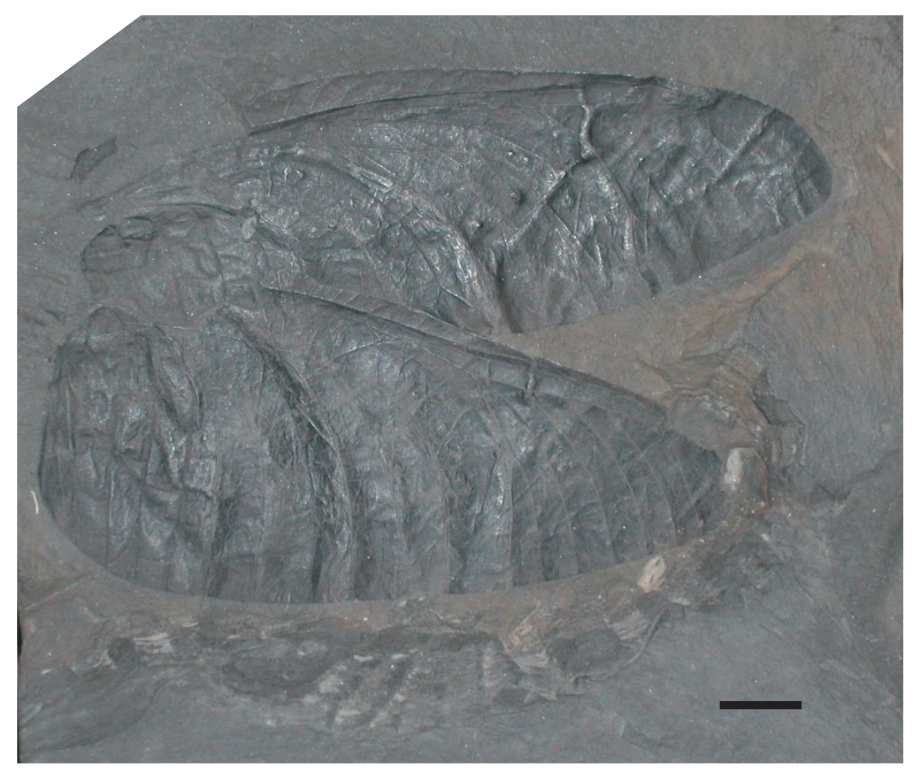

a.

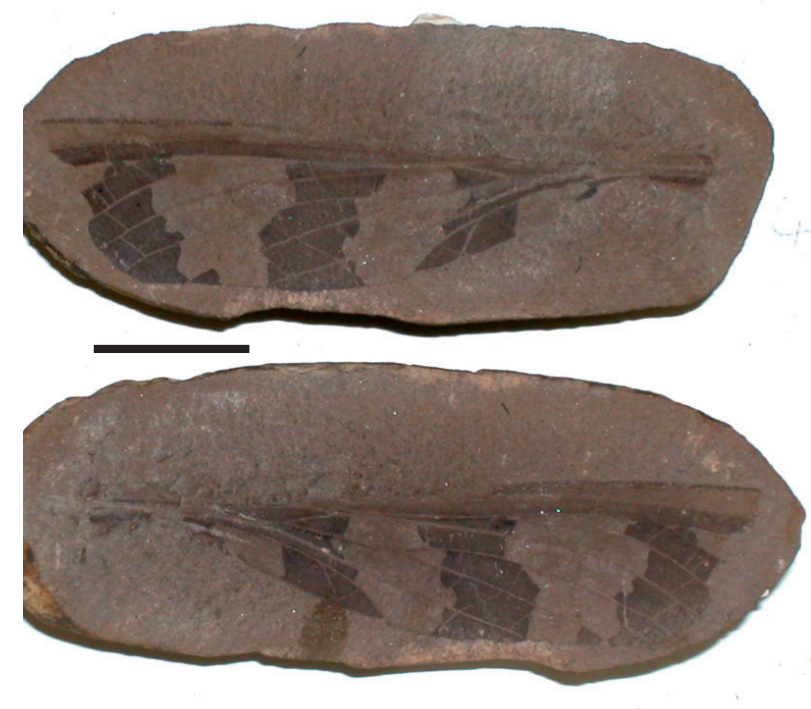

$b$.

Fig. 44. a. Broad-winged palaeodictyopteroid: Breyeria vrankeni Laurentiaux-Vieira \& Laurentiaux, holotype, Naturalis, Leiden (Duckmantian, the Netherlands); b. Narrow-winged palaeodictyopteroid: Brodia priscotincta Scudder, BIRUG 4270, Lapworth Museum, Birmingham (Duckmantian - (?) lower Bolsovian, UK). 
dominated by the extinct palaeodictyopteroid orders which are a diverse group with no exact modern counterparts (Prokop et al., 2006; Fig. 1). Much less common, but more famous, are the dragonflies (Meganisoptera) which include some of the largest insects of all time and are considered under gigantism. The non-pterygotes appeared earlier in the Early Devonian and continued through Pennsylvanian times with distinctive forms like the extinct apterygotan monurans (Carpenter, 1992).

\section{World wide web}

An international fossil insect database called EDNA went on-line with the support and during the latter part of this Project (http://edna.palass-hosting.org/search.php). It is thus exactly one hundred years since the last detailed compilation published in two volumes by Handlirsch (1906-08). EDNA is so called because it originated as a card catalogue commenced by Mrs Edna Clifford and subsequently developed into a relational database in Microsoft Access (Mitchell, 2003, 2007). There are three main search fields for stratigraphy, locality and species. There is a selection of nearly forty output fields grouped into taxonomic hierarchy, published references, site and stratigraphic details, as well as a miscellaneous category including synonyms (The species synonymy rate is about 15\% which is less than average in entomology because there are fewer palaeoentomologists than entomologists). In addition to capturing all known species which is still in progress (over 25,000 but beginning to level off), a major task has been augmenting the published information because it's rarely comprehensive (Outstanding queries on EDNA are indicated by a dollar sign \$). Many species were described by systematists rather then geologists so that there is scope for improving the stratigraphic resolution through desktop studies, especially in muchdocumented coal-bearing strata (Roscher \& Schneider, 2005). The necessary international cooperation to evaluate the latter has been facilitated by IGCP 469, with members of the project checking country listings. The EDNA records are based on types and further work is needed to include all ranges, although for most species this is limited both spacially and temporarily. Distributional studies of supra-specific taxa could therefore prove of greater palaeogeographical significance.

As in Handlirsch's time, late Palaeozoic insects are a major part of EDNA and continue to be of high phylogenetic interest. Distributional studies are in their infancy, but there are over 1,272 described species from the Carboniferous alone, mostly Westphalian-Stephanian in age, and distributed unevenly across nineteen countries (Table 11). More than half of the Carboniferous species (775) are known from Europe. Of the non-European countries, the great majority of species are known from the USA with 412 of the total of 493 species. Of the countries represented in IGCP 469 only two (Bulgaria and Poland) have no EDNA records yet, and one (Romania) has just been published (see beyond). Such gaps need filling. There is
Table 11. Number of Carboniferous insect species in Europe (in decreasing number then alphabetically). Based on EDNA search July, 2008.

\begin{tabular}{llll}
\hline Europe & \multicolumn{3}{l}{ Rest of world } \\
\hline France & 323 & North America (USA, Canada) & 423 \\
Germany & 289 & Australasia + Russia* & 43 \\
United Kingdom & 80 & South America (Argentina, Brazil) & 22 \\
Czech Republic & ca. 33 & Africa (Zaire) & 1 \\
Belgium & 27 & & \\
The Netherlands & 7 & \\
Portugal & 10 & & \\
Spain & 2 & \\
Switzerland & 2 & \\
Austria & 1 & \\
Ukraine & 1 & \\
* Russia has been combined with Australasia as the Federation contains many \\
$\quad$ Asian fossil insect localities.
\end{tabular}

undescribed material even in well-collected countries so that the number of records is likely to increase.

\section{Biozones}

Blattodeans (cockroachoids) are, in general, a common and widespread Pennsylvanian order of insects, although there can be exceptions (e.g. the lower Westphalian Substage of the Pennine Basin, UK, where they tend to be rare probably due to the predominance of lacustrine conditions) They have therefore been used for biostratigraphy, often in combination with other animals also preserved in wetland clastic sediments, especially conchostracans (clam shrimps) with time resolution down to an estimated 1.5-2 Ma (Schneider \& Werneburg, 2006). The simple scheme with archimylacrid zones in the Westphalian Stage and spiloblattinid ones in the Stephanian to Asselian stages (Schneider et al., 2003) was beginning to show problems in the Asturian-Cantabrian transition by the beginning of this Project. These were resolved with the introduction of a mylacrid assemblage zone (Jarzembowski \& Schneider, 2007: table 3). During the late Westphalian - early Stephanian interval being consideration in IGCP 469, archaic Archimylacris gave way to patterned Sysciophlebia and Syscioblatta (Fig. 45). Phyloblattidae, which appear in the middle of the Westphalian Stage, are still a minor component of the late Asturian faunas of Writhlington and the Necymylacridae do not survive the Cisuralian (early Permian) Epoch.

\section{Insects and climate}

Insects are cold-blooded organisms and therefore sensitive to the temperature of their surroundings. Breathing air through tracheae and gills, they are also sensitive to atmospheric composition. Both adaptations provide evidence of the Carboniferous climate. 


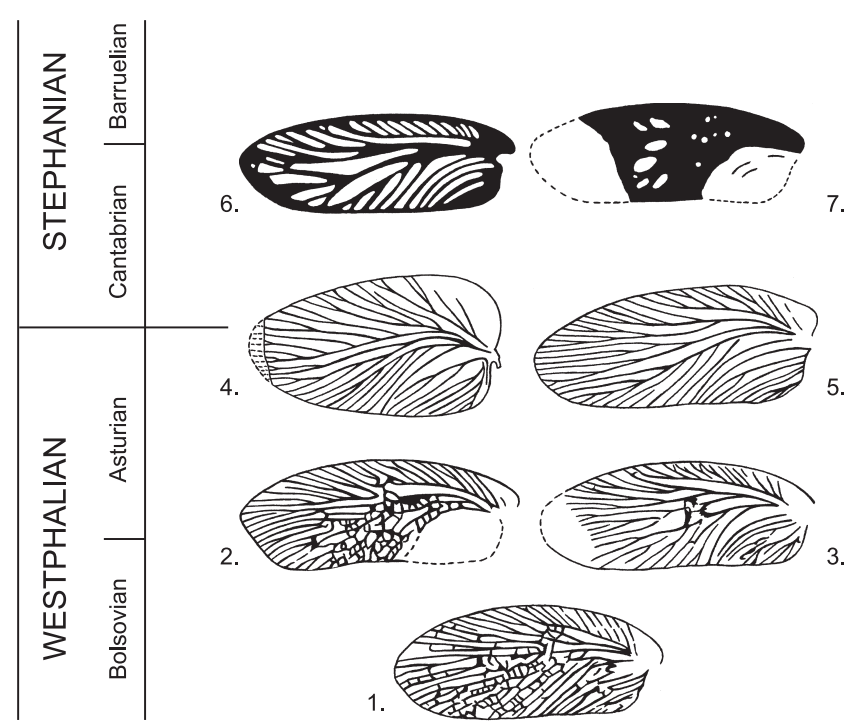

Fig. 45. Zonal cockroachoids for the mid Westphalian-early Stephanian (adapted from Schneider et al., 2005; Bolton, 1912). Key to species: 1 - Archimylacris lubnenesis Kušta; 2 - Archimylacris f. Zwickau; 3 - Kinklidoblatta morini (Pruvost); 4 - Sooblatta burri (Bolton) (representing the Mylacris abrupta-Sooblatta burri-Sooblatta deanensis Assemblage Zone); 5 - 'Syscioblatta' corsini Laurentiaux; 6 - Sysciophlebia sp. A; 7 - Syscioblatta intermedia (Scudder).

Durden (1984b) suggested that the recurring Pennsylvanian entomofaunas with large mylacrid blattodeans (cockroachoids) represent episodes of moister climate (i.e. lack of drought) in a seasonal wetland biome, corresponding to the pluvials of the Gondwanan glaciation. The recognition of a new mylacrid zone in the Asturian-lower Cantabrian interval by Jarzembowski \& Schneider (2007) in northwest Europe could therefore have environmental significance; also, the lower Cantabrian Drybrookia cubitalis Bolton from the Forest of Dean Coalfield, UK, is certainly not a small mylacrid (Bolton, 1924). However, Lucas et al. (2006) have expressed some reservations about Durden's interpretation. Moreover, an undescribed Pennsylvanian-age giant cockroachoid from the Appalachian Basin of Ohio, USA, is $90 \mathrm{~mm}$ long which compares well with the $100 \mathrm{~mm}$ largest living cockroach, the tropical Giant Cave Cockroach (Gorder, 2001). A qualitative assessment of general insect body size is given in Table 12. Large insects appear to give way to small or average size ones in the Bolsovian-Stephanian interval. Overall, this could reflect environmental changes, but needs quantitative and taphonomic investigation. Tantalisingly, a

Table 12. General insect size compared with modern entomofauna after Durden (2005).

\begin{tabular}{ll}
\hline Stratigraphical interval & Insect size \\
\hline Late Mississippian - early Asturian & Large \\
Middle - late Asturian & Small with few large \\
Cantabrian & Similar with few large \\
middle - upper Stephanian & Small \\
\hline
\end{tabular}

Wagnerian parsimony analysis of dragonfly morphology and palaeosynecology points to important changes having taken place during late Westphalian (Moscovian) times in insect predator/prey relations (Nel et al., in press).

Durden (1984a: fig. 6) also reconstructed the tropical/ subtropical belts for the mid-Asturian to early Stephanian time-interval based on insect 'life zones'. The tropical belt included most of the North American fossil insect localities, albeit only a few hundred miles wide. Extrapolating these insect 'life zones' beyond North America takes in much of Europe from Scotland to North Africa (Fig. 46) and this could be refined by analysing further the data in the EDNA database. Preliminary study shows that there are fewer Carboniferous insects (both described and undescribed) known from the extrapolated peripheries of the 'life zones' either side of the palaeoequator in the UK and Spain (personal tally; Arillo et al., 2007), which might imply a thermal gradient.

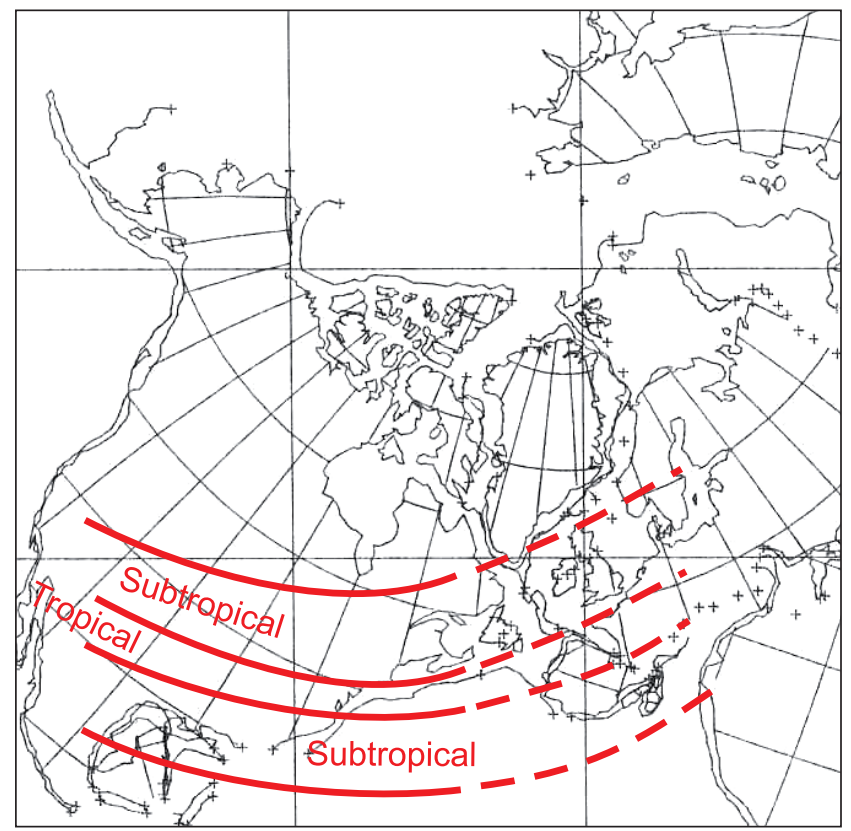

Fig. 46. Tropical and subtropical insect 'life zones' in Carboniferous Euramerica (base map based on Torsvik \& Cocks, 2004) extrapolated (broken boundaries) from Durden (1984a) (solid boundaries).

The presence of exceptionally large species of arthropods in Asturian-Stephanian times has led to the claim that 'gigantism was genuinely the order of the day' (Beerling, 2007: 40). This claim is important as it is used as biological support for an oxygen-rich Carboniferous world (Lane, 2002). It is certainly true that the extinct stem-group dragonfly Meganeura monyi Brongniart (from the Stephanian B/C of Commentry, central France) had a wingspan approaching $0.7 \mathrm{~m}$, larger than any living dragonfly, and that the 'millipede' Arthropleura grew even larger (Fig. 47). It is also true, however, that these are both uncommon and uncommonly large animals in the context of the Carboniferous terrestrial arthropod fauna (Jarzembowski, 2001b). Moreover, Zherikhin (2002: 337) noted a recurrence of 


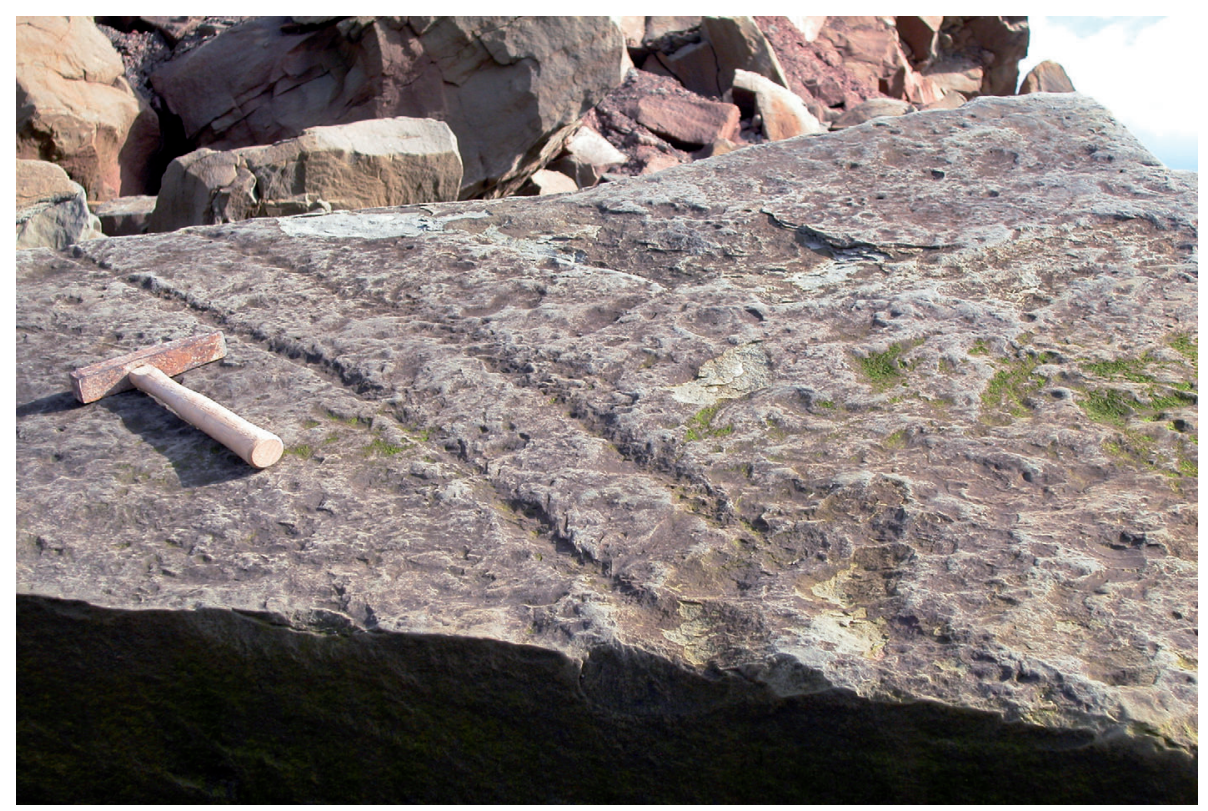

Fig. 47. Arthropleurid trackway: Diplichnites, Joggins, Nova Scotia (Langsettian, Canada).

gigantism in the late Triassic, post-hyperoxic world (Belcher \& McElwain, 2008). How are these views reconciled? Either the combustible, high-oxygen Carboniferous world model has led to an exaggerated interpretation of the fauna or normal rules of ecology (such as predator-prey and trophic relationships) only permitted limited gigantism. On the latter view, large dragonflies may be seen as a size ('arms') race with large, plantfeeding palaeodictyopteroids in the absence of flying vertebrates; large millipedes would have been a challenge for burgeoning terrestrial (reptilian) predators. Gigantism could have been facilitated by exceptional atmospheric composition (cf. Labandeira, 2002), but could equally well record terrestrial arthropods reaching their true potential in the absence of birds and mammals. A possible test for these alternative hypotheses would be overwhelming evidence of contemporaneous wildfires but significant quantities of charcoal (fusain) are absent in Carboniferous insect-bearing clastic deposits (personal observation); Durden (2005) only observed fusain (charcoal) with large insects in Autunian deposits. This infrequency is noteworthy because the relatively inert form of carbon in charcoal should result in selective preservation and increased abundance. Interestingly, Braddy et al. (2008) considered that gigantism in Middle Devonian eurypterids (water scorpions) also reflected lack of vertebrate predators (fish) rather then hyperoxia. Atmospheric oxygen levels were unexceptional at this time and indeed lower than today (Beerling, 2007: fig. 3). It may be argued that aquatic giants live in a denser medium than terrestrial ones, which limits any direct comparison, although dragonflies inhabit both media during their life histories. Butterfield (2009) considered that hypoxia could have actually increased terrestrial diversity in early Devonian and Carboniferous times (contra Ward et al., 2006) and that oceanic, sediment and soil ventilation were more significant than atmospheric oxygenation throughout the Phanerozoic.
Okajima (2008) undertook a quantitative allometric study of Phanerozoic dragonflies and concluded that sizes were either too large (Carboniferous) or too small (Jurassic) compared with theoretical ones based on oxygenation alone: additional factors had to be involved such as atmospheric temperature, density, pressure and vertebrate predation (post Triassic). The climatic significance of Carboniferous gigantism is therefore unclear except that giant animals must have lived in equable conditions to grow to such size. The fossil record does, however, provide a biological reality check on physical and statistical modelling of past natural systems.

\section{Insect interaction with other organisms}

A surprising feature of the Carboniferous entomofauna is that six out of the seven modern insect feeding groups were already present - surprising because they pre-date the rise of the angiospermous flowering plants (Labandeira, 2006). The groups present are external foliage feeding, piercing-andsucking (Fig. 48), boring, galling, seed predation and even oviposition; only leaf mining appears to be absent. Labandeira (2006) linked this to hothouse atmospheric composition but 'by uncertain causes, although some relationship probably is present'. Unfortunately, insect/plant interaction is rarely formally described (despite such trace fossils being included in the International Code of Zoological Nomenclature) so that systematic analysis is difficult (for an exception, see Castro, 1997). This is because of a tradition in zootaxonomy which seeks only to identify 'natural' taxa based on selected body parts and rejects parataxonomy which is usefully widespread in palaeobotany. This philosophical difficulty, however, could be the subject of a separate Project.

A more useful signal is provided by insect colour patterns although their preservation is not fully understood. These were 
Fig. 48. Piercing-and-sucking damage on lycopsid fertile leaf (Lepidostrobophyllum), Joggins Fossil Centre, Nova Scotia. A possible megasecopteran perpetrator (undescribed) is known from the same deposits.

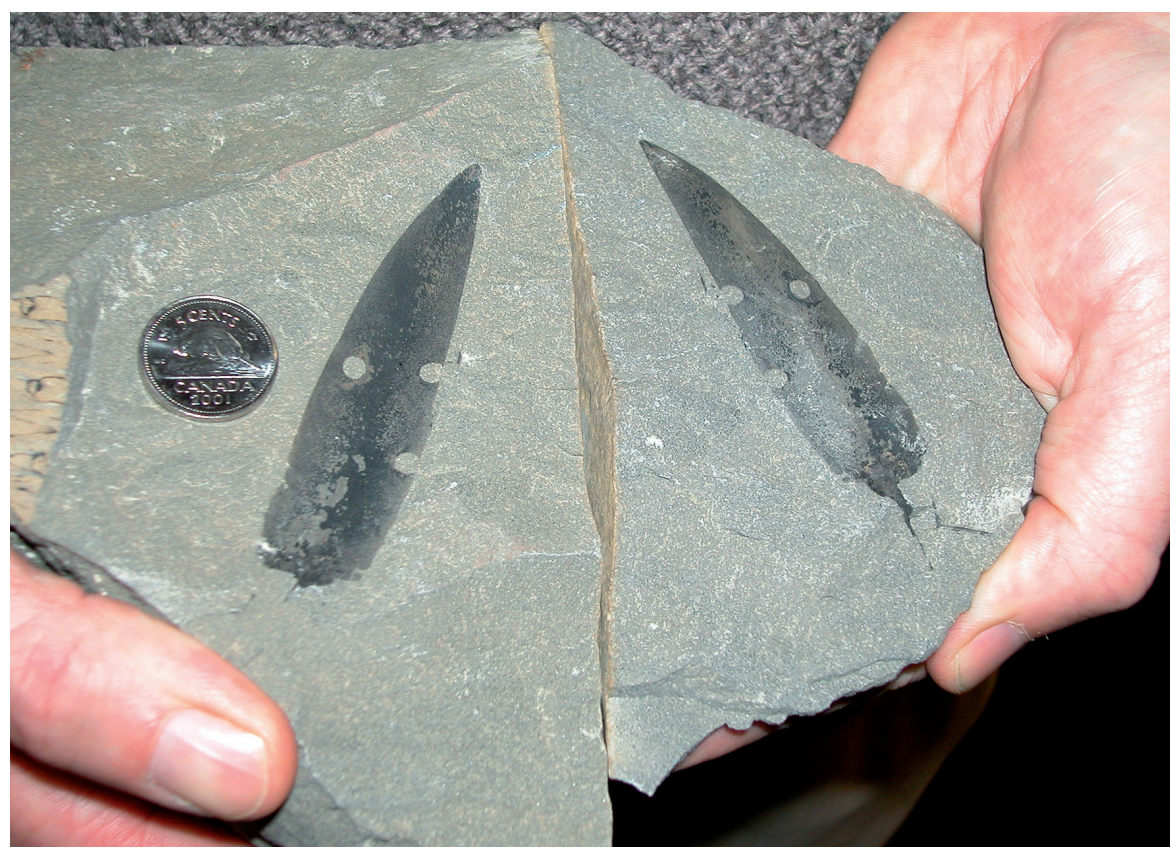

reviewed by Jarzembowski (2005b) who concluded that cryptic patterns may characterise the late Westphalian, but that deimatic behaviour was established by the late Stephanian, suggesting increased vertebrate predation in CantabrianBaruellian times. The fossil record of terrestrial tetrapods is sparse before the Permian Period, but in Pennsylvanian times small generalised amniotes such as romeriids and protothyridids are considered to have been insectivorous, at least in the smaller, juvenile stages (Ms T. Meyer, University of Calgary, pers. comm.). In addition, non-amniotes (amphibians) probably included smaller terrestrial forms such as Scincosaurus in Asturian times (Mr D. Marjanovič, CNRS, pers. comm.) which is consistent with them occurring alongside the burgeoning reptiles. These are, however, ecological rather than climatic drivers which may also account for some of the faunal changes in cockroachoids such as stripey colour patterns (Spiloblattinidae, some of which are dimorphic) and forewing tegminisation (Mylacridae) as well as decreasing and small insect size (Table 12).

\section{Carboniferous entomofaunas}

Regional faunal comparisons are still mainly in the narrative stage appended to systematic accounts. For example, the Iberian fauna is in the descriptive stage (Arillo et al., 2007) while Jarzembowski (2004) and others have noted the similarity between the late Asturian roof shales of Writhlington in southwest England and the Asturian/Cantabrian Braidwood fauna from the Mazon Creek nodules in the eastern USA. In a more quantitative approach, Easterday (2005: 40) used six similarity coefficients to compare the new Appalachian locality of Cemetery Hill (easrly Missourian, or latest Cantabrian/earliest Baruellian) with 14 other Euramerican sites to show that it was transitional between the classic faunas of Mazon Creek and of
Commentry. Proctor (1994) used divisive cluster analysis to recognise biotic assemblages in insects and associated organisms at Writhlington. There are now new opportunities for faunal studies with the on-line EDNA database.

The uneven distribution of Upper Carboniferous insects has already been noted and Jarzembowski (2008) has recently filled a gap in eastern Europe (Romania), but more work is needed. For example, there is an undescribed nodule fauna from Polish Silesia housed in the Institute of Systematics \& Evolution of Animals, Krakow (Fig. 49); new Carboniferous insects have been found in Canada, which has considerably fewer published records than the USA (E.L. Zodrow, pers. comm.). Comparison with little-known regions outside the heartland of palaeotropical Euramerica is also needed to test assumptions based on what are often long-extinct insect groups. In this connection, new work has commenced on the Cathaysian fauna (Prokop \& Ren, 2007; Ren et al., 2008).

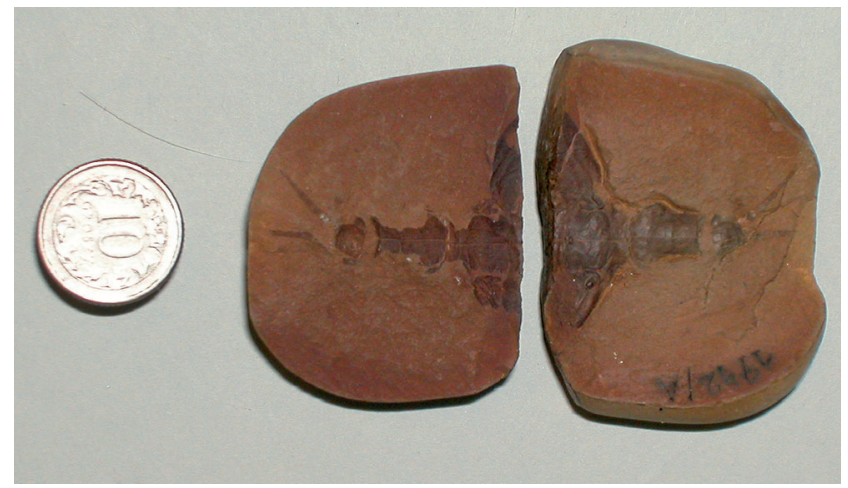

Fig. 49. An undescribed gerarid (hemipteroid 'protorthopteran') with elongated, spiny prothorax as protection against predators: 1942A/B, Natural History Museum, Krakow (Langsettian, Poland). This family is typical of the Asturian-Cantabrian transition (Shabica \& Hay, 1997). 


\section{Conclusion}

One of the objectives of IGCP 469 was to increase our understanding of biotas and environmental change at the Westphalian-Stephanian transition. The insect data shows that changes in the Blattodea (cockroachoids) are of biostratigraphical significance with Archimylacridae being replaced by Spiloblattinidae across the transition; Mylacridae, however, have also proved useful, at least in north-west Europe. Other insect groups await specialist treatment, such as the 'protorthopteran' complex (Béthoux \& Jarzembowski, in press). Another notable change is the increased sophistication of colour patterns in insects, with eyespots making their debut in Stephanian times. These changes were probably evolutionary and ecological (although recurring large mylacrids could be climatic indicators). The evidence from gigantism in dragonflies and other arthropods does not give a clear climatic (atmospheric) signal - contrary to some recent claims - except for pointing to the general equability of the environment. Interestingly, independent data from insect/plant interaction studies reached a similar conclusion.

In spite of their short lives, insects can fly or walk out of trouble. Faunal changes may therefore be more subtle than some floral ones at this time (Easterday, 2005), in which case the burgeoning on-line fossil insect database (EDNA) should prove an international resource for future studies, especially as evolution is ultimately at the species level. EDNA has already shown the uneven spread of records and future work should seek to redress this imbalance, as well as initiate new studies within and outside the classical Euramerican palaeotropics. Further refinements are needed (e.g. in ranges) and some have already started (e.g. stratigraphical updates). A century after Handlirsch's (1906-08) monumental monograph, and effectively a generation after Carpenter's (1992) generic encyclopaedia, palaeoentomology has finally come of electronic age during this Project.

\section{Arachnids (C. J. Cleal)}

Although well represented in the Mazon Creek biota of Illinois (Shabica \& Hay, 1997), arachnids have been poorly recorded from the upper Westphalian and lower Stephanian of Variscan Euramerica. The most recent synthetic analysis of arachnids of this age was by Petrunkevitch (1953) but he gave no biogeographical or biostratigraphical analysis of his data. Many of the Westphalian records of such fossils from Variscan Euramerica came from the Sparth Bottoms (Lancashire) and Coseley (West Midlands) lagerstätte in the Pennine Basin, which are both older than the time interval being considered here (late Langsettian and middle Duckmantian, respectively). Apart from scattered records from the South Wales, Pennine, Scottish, Nord-Pas-de-Calais, Belgian, Saar-Lorraine, Zwickau and possibly Upper Silesia basins, most late Westphalian arachnids recorded by Petrunkevitch (1953) originated from central Bohemia, from both the Radnice and Nýřany members. More recently, a number of arachnids have been recovered from the late Asturian Farrington Formation at Writhlington in the Radstock Coalfield of southern UK (Beall, 1991; Dunlop, 1994a, 1994b).

A simple reading of the Petrunkevitch (1953) data set suggests a high level of species diversity and faunal provincialism (see comments by Rolfe, 1980); each locality seems to have a different fauna, and few species occur at more than one locality. However, Dunlop (1994b) has queried such an interpretation, suggesting that many of these arachnid taxa were poorly defined and that further work would probably result in many of the names disappearing through synonymy. As an example, he showed that trigonotarbids described under four different species names from Mazon Creek, South Wales and Radstock were in fact the same species, Pleophrynus verrucosa (Pocock). If this interpretation can be confirmed, it would suggest that the late Westphalian - early Stephanian arachnid biogeography of Variscan Euramerica may be comparable to that of the macrofloras. If so, it would be of interest to see if the intramontane basins yielded different arachnid faunas compared to the coastal lowland basins.

\section{Discussion}

Based on this study, our interpretation of the palaeogeography of Variscan Euramerica is summarised in Fig. 1. In essence an east-west belt of uplands (the Variscan Mountains) that formed as a consequence of the collision of the Laurussia-Avalonia and Gondwana plates, with the western Tethys Ocean to the south and the foreland area with the main area of coal swamps to the north. In this reconstruction, we estimate that in middle Moscovian times the area of coal swamps in Variscan Euramerica to have been c. $1,500 \times 10^{3} \mathrm{~km}^{2}$, which broadly agrees with the combined figures given by Cleal \& Thomas (2005) for the Canadian Maritimes, and the European intramontane and Variscan foreland basins (the latter including part of what was called in the earlier study the Donets Basin, west of the Black Sea). For much of Moscovian times the ecological structure of the swamps remained essentially stable (DiMichele \& Phillips, 1996b; Pfefferkorn et al., 2008) but in the second half of this age the area covered by the swamps in Variscan Euramerica went into decline as the clastic sediment derived from the advancing Variscan Front progressively segmented the depositional areas (Edwards, 1998). Fig. 50 shows maps with the main areas of swamp development plotted for six time intervals, representing the six macrofloral zones/subzones for the upper Duckmantian to lower Cantabrian substages, and from this we can estimate the pattern of decline of the coal swamps across Variscan Euramerica (Fig. 51). There is a certain amount of speculation in this, especially as there is still some uncertainty about the northern margins of the area where coal swamps developed, much of which is now under the sea. Also, 
Late Duckmantian - early Bolsovian

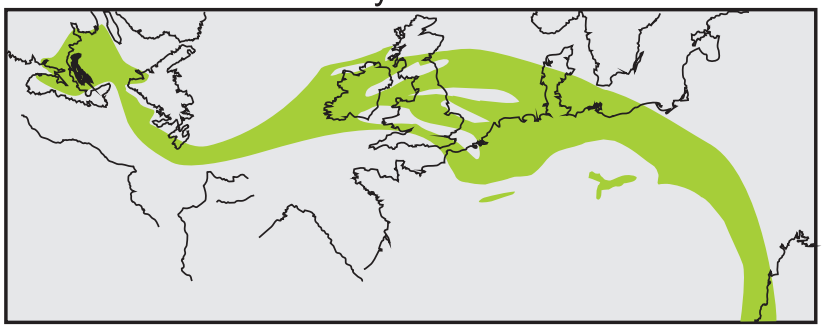

Early Asturian

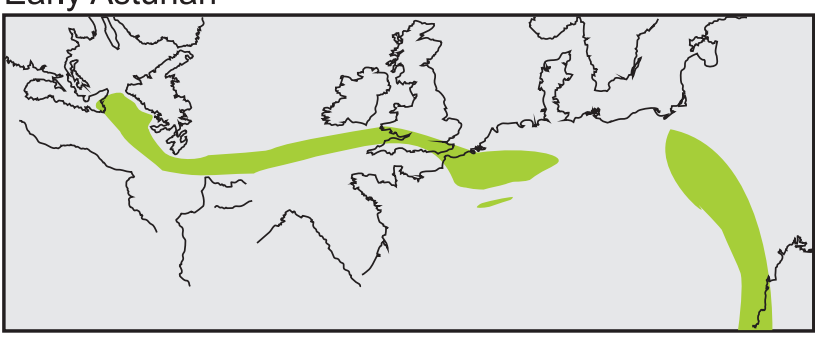

Late Asturian

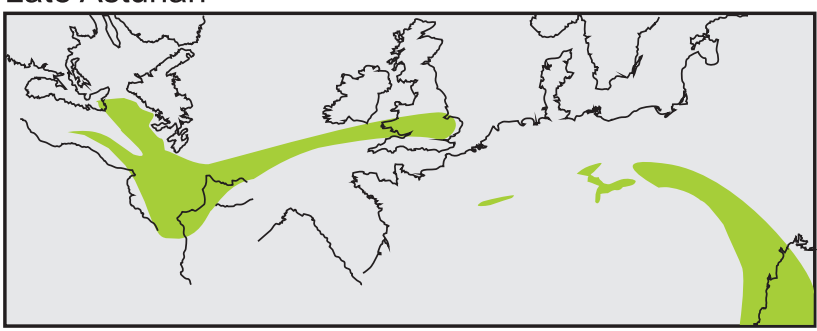

Late Bolsovian

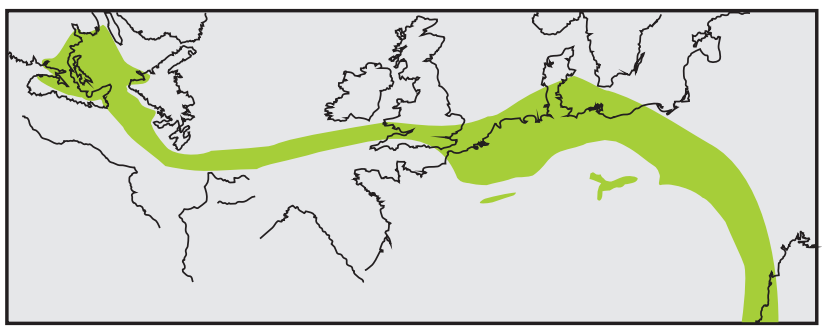

Middle Asturian

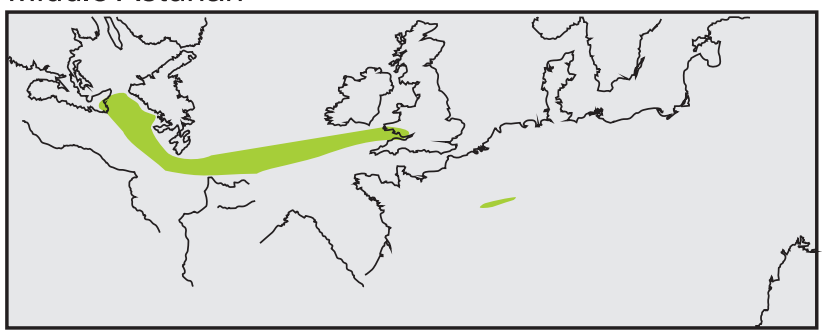

Early Cantabrian

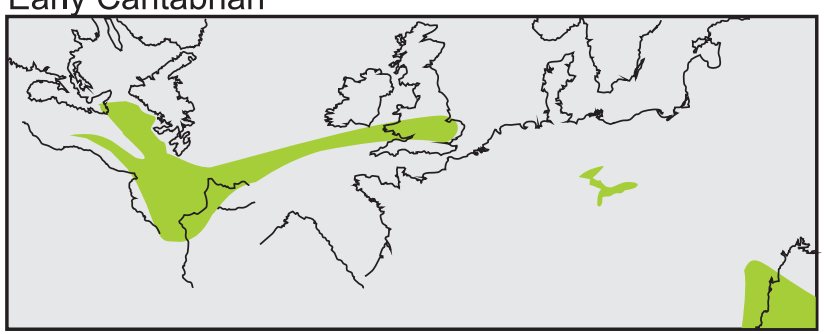

Fig. 50. Distribution of coal swamps in Variscan Euramerica in six intervals from late Duckmantian to early Cantabrian times. The time bins are equivalent to the macrofloral zones/subzones: late Duckmantian - early Bolsovian = N. semireticulata Subzone, late Bolsovian = L. rarinervis Subzone, early Asturian = L. obliqua Zone, middle Asturian = L. micromiltoni Subzone, late Asturian = D. plueckenetii Subzone, Cantabrian = 0. cantabrica Zone.

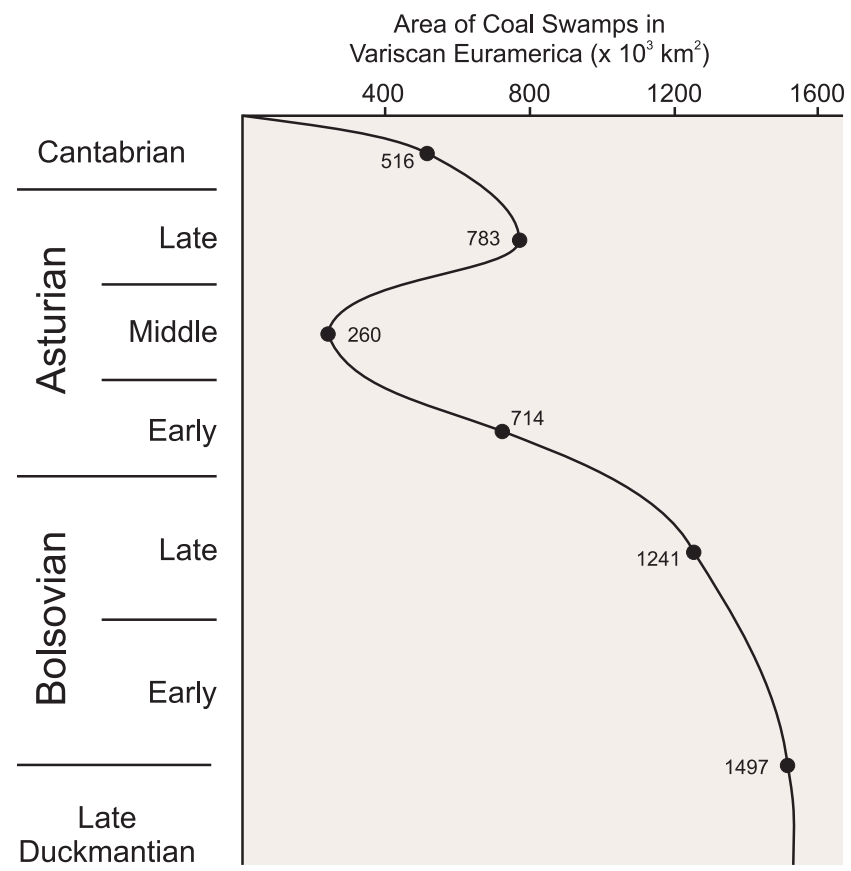

Fig. 51. Changing area covered by coal swamps in Variscan Euramerica, based on maps shown in Fig. 49. The areas were estimates by counting grid squares on enlarged print-outs of the maps. some deposits have clearly been removed during the inversion phase and collapse of the Variscan orogen, so what we see now is only a remnant of what was originally there. Nevertheless, by incorporating evidence of facies and thickness changes that suggest the approaching basin margins, it has been possible to get a reasonable idea of the original extent of the swamps.

During Bolsovian times there was a general decline in the development of coal swamps in the cratonic basins in the more northern part of the Variscan foreland as increased coarser clastics were introduced into the basin and the water table fell; both changes would have been unfavourable for the arborescent lycopsids which dominated the swamp vegetation. We have no direct evidence as to what caused these topographic and hydrological changes, but they coincided with the influx of coarse clastic deposits into the more southern foreland areas such as South Wales and the Ruhr Basin, which is interpreted as a response to the northwards migration of the Variscan Front; this movement of the southern plate may also have triggered uplift of the northern hinterland that drained into the cratonic area.

Overall, however, the area of coal swamps in Variscan Euramerica remained essentially constant at this time, as there was also a coincidental westwards extension of the swamps 
into the Canadian Maritimes. The subsidence that allowed the coal swamps to migrate into the Canadian Maritimes has also been interpreted as the result of orogenic activity.

In those parts of the cratonic foreland where water tables remained high and peat continued to accumulate (e.g. central parts the Pennines Basin - Marshall \& Smith, 1964) Lycospora dominates the palynofloras of most coals, indicating that the vegetation still consisted mainly of arborescent lycopsids. Further east, however, in central and eastern Europe (Upper Silesia and Dobrudzha), the coal palynofloras have a much higher proportion of monolete spores indicating the vegetation was taking on more of a mixed tree fern - lycophyte character (Jachowicz, 1972; Jachowicz \& Dybova-Jachowicz, 1983; Dimitrova \& Cleal, 2007). The evidence from the tuff deposits in the lower Bolsovian Radnice Member of central and Western Bohemia also suggests the peat substrates here supported a mainly mixed tree fern - lycophytes vegetation (0pluštil et al., 1999, 2007, 2009).

The fall in species diversity in the upper Bolsovian adpression floras, mainly among the lyginopteridaleans and lycopsids, suggests a shift in composition of both the peat and clastic substrate vegetation. In the Pennines and Ruhr this decline is part of a widespread collapse of the coal swamp habitat. In South Wales and Saar-Lorraine, however, diversities had stabilised by the end of Bolsovian times. Since this drop in diversity occurs in both lowland and intramontane basins it may have been a response to some extrinsic, perhaps climatic change. Alternatively it may have been a precursor to the more fundamental change from lycopsid-dominated to mixed fernlycopsid vegetation that occurred in middle Asturian times, and which we will argue later to have been the result of tectonic movement destabilising the landscape and drainage patterns.

The withdrawal of marine influence during Bolsovian times, probably in response to the global regression caused by the growth of the Gondwana ice sheet, seems to have had little direct effect on the size of the wetlands. However, these eustatic events did have some impact on the detailed composition of the clastic substrate vegetation, as reflected in the adpression macrofloras. In those areas where marine influence continued longest, notably in Britain, the Ruhr and northern France, the upper Duckmantian - lower Bolsovian macrofloras are sufficiently distinct from those of the upper Bolsovian Substage that they are recognised as a separate subzone; where there was little or no marine influence, such as Upper Silesia and Saar-Lorraine, these subzones are not distinguished. Palynological evidence of the effects of this marine influence on the peat substrate vegetation is less clear.

The overall area of coal swamps started to decline significantly during late Bolsovian and early-middle Asturian times. The earliest evidence of this is in the cratonic parts of western Europe such as the Pennines Basin, which suggests that it was not caused by the withdrawal of marine influence from across the foreland, as the stratigraphically youngest marine band are found here. However, the swamps subsequently started to disappear from other areas, notably in central and eastern Europe. This reduction in the area of coal swamps to less than $20 \%$ of their former size was associated with increases in the input of clastic sediment into the basins, which in turn appears to have been related to a Europe-wide pulse of tectonic activity (the Leonian Phase). The increase in clastic-input into the coal basins may have hampered the build-up of peat necessary to sustain the coal swamp habitats. There is also some evidence of increased aridity in the form of red-beds, which unlike those of the Bolsovian Substage include caliche deposits (Besly, 1988). However, the aridity was localised (Besly, 1988) and in other areas such as South Wales and SaarLorraine, the coal swamp vegetation continued to flourish; Besly (1988) has argued that high levels of precipitation also continued in the catchment areas adjoining the depositional basins. A remarkable feature of the coal swamp vegetation was its ability to reconstruct itself even after quite substantial ecological disturbance (DiMichele et al., 1996) but this would only have been possible if there were still areas available where the wetlands could develop. It seems unlikely, therefore, that these caliche-bearing red-beds were the result of continentwide changes in precipitation patterns, which would surely have had a more profound impact on the ability of the coal swamp vegetation to survive.

This localised aridity may have been caused by the localised loss of the lycopsids as the dominant vegetation due to substrate and water table disturbance. As with many modernday tropical habitats, dense vegetation generates significant levels of atmospheric humidity through transpiration and this helps maintain high rainfall levels in those areas (Shukla et al., 1990; Webb et al., 2006). Even localised loss of vegetation cover in today's tropical areas can cause a marked, localised aridity (Sheil \& Murdiyarso, 2009). We do not know the Water Use Efficiency (sensu Pallardy \& Kozlowski, 2008) of the arborescent lycopsids and aspects of their anatomy may have placed some limitations on water transport through individual plants (Phillips \& DiMichele, 1992). However, their phenomenal growth rate must have been the result of very high rates of photosynthesis requiring a substantial output of moisture through transpiration. Moreover, the open nature of these wetland habitats with very limited plant canopy will have facilitated substrate evaporation. The resulting high rates of evapotranspiration will have increased precipitation in the areas where the arborescent lycopsids were growing and thus provide a positive feedback to help maintain the wetlands.

As pointed out by DiMichele et al. (2009) a negative feedback between the decline in the arborescent lycopsids and the reduction in evapotranspiration-fed rainfall on which the lyciopsids depended may have been a major factor in the reduction in the overall area of this swamp vegetation. The lycopsid-dominated vegetation was initially replaced by more 
mixed vegetation where the lycopsids became co-dominant with marattialean ferns. In Variscan Euramerica, middle Asturian palynofloras show a marked increase in marattialean spores such as Thymospora obscura in both coals and clastic deposits (Dimitrova et al., 2005, in press; Dimitrova \& Cleal, 2007; Cleal et al., 2007); the change is sufficiently marked that it is recognised as an index to the base of the OT Zone in the standard palynological biostratigraphy of Clayton et al. (1977). These tree ferns were of relatively 'cheap construction' and thus presumably quick growing (Baker \& DiMichele, 1997; DiMichele \& Phillips, 2002), but critically were unlike the lycopsids in that they had an indeterminate growth strategy; a stand of marattialean tree ferns would have represented significantly less of an active carbon sink than a similar stand of arborescent lycopsids. Lower productivity would have resulted in lower levels of transpiration, which may have reduced local atmospheric humidity and therefore rainfall. Where conditions became even drier, peat accumulation ceased and the vegetation became dominated by seed-plants, notably cordaites and conifers. The leaves of these plants had sunken stomata often protected by papillae (e.g. Florin, 1938-1945; Barthel, 1964; Scott \& Chaloner, 1983; Šimůnek, 2007b) that were adaptations to reduce levels of transpiration, which in turn would continue to reduce local atmospheric humidity and therefore rainfall.

The clastic substrate vegetation within the coal swamps also underwent changes during middle Asturian times, which in the macrofloral biostratigraphy is represented by the base of the Lobatopteris vestita Zone. Where the coal swamps continued to grow, species diversity increased at this time, notably through the appearance of additional taxa of marattialean tree ferns and medullosalean seed plants. There was also a significant change in the relative biomass represented by these plant groups (Davies, 1929; Cleal, 2007). The increased abundance of the marattialeans in the clastic substrate vegetation obviously mirrors the response of the peat substrate vegetation to better drained substrates. Whether the medullosaleans also became more widespread in the peat substrates is not known as their pollen tends to be very poorly represented in most palynofloras (e.g. Dimitrova et al., 2005) and there are no coal ball floras of this age found in Variscan Euramerica. Notably, both of these groups of plants that came to dominate the middle and late Asturian clastic substrate habitats appear to have been larger trees than their middle Westphalian counterparts (Lesnikowska, unpublished PhD thesis as reported by DiMichele \& Phillips, 2002; Zodrow, 2002, 2007; DiMichele et al., 2006). The new medullosalean trees mostly had Alethopteris fronds, which had a prominent hypodermis below the epidermis, a feature usually associated with leaves growing in more exposed positions (Arens, 1997), suggesting the crown of these trees was well above the surrounding vegetation. At least some of these medullosaleans also had extremely large ovules - in fact the largest ovules of any known gymospermous seed-plant (Cleal et al., in press), suggesting an adaptation to germination in more shaded habitats with denser vegetation (Foster, 1986).

The coal swamps underwent something of a resurgence during late Asturian times, trebling the area that they covered, although still significantly less than their middle Westphalian extent. They re-appeared mainly in central and eastern Europe, such as in the foreland basins of Upper-Silesia and Dobrudzha, and the intramontane basins of the Bohemian Massif. They also briefly returned in the cratonic Pennines Basin, although with fairly limited peat-generation. Except for the intramontane basins, however, this return of the coal swamps was only temporary, and mostly associated with relatively coarse clastic sediment and red-beds. Where the coal swamps continued through uninterrupted from early Asturian times, the species diversity of the macrofloras remains relatively constant, suggesting little in the way of extrinsic climatic change. This resurgence of the coal swamps was probably a response to a pause in tectonic activity allowing more quiescent conditions to develop again in these parts of the lowlands. In the few areas where there is late Asturian palynological evidence, tree ferns appear to have made increasing inroads into the peatsubstrate vegetation. In the Canadian Maritimes and Britain, an essentially mixed lycopsid - fern vegetation was present (Dimitrova et al., 2005, in press) whereas in Upper Silesia, Central and Western Bohemia,and Dobrudzha ferns were now dominant in most parts of the swamps (Jachowicz, 1972; Jachowicz \& Dybova-Jachowicz, 1983; Šimůnek, 1994; Dimitrova \& Cleal, 2007; 0pluštil et al., 2007). In both the clastic and peat substrates, the callistophytes make their first serious contribution to the vegetation, probably replacing niches previously occupied by lyginopteridalean scrambling and lianescent plants.

After this brief resurgence, the coal swamps continued to contract across Variscan Euramerica during Cantabrian times, initially disappearing from Upper Silesia and parts of the Bohemian Massif, and subsequently from most of the rest of the area. In several basins, the upper part of the preserved Carboniferous succession was removed by post Moscovian erosion and so details of the changes that took place at this time are difficult to judge. However, in the Sydney, Pennines, Upper Silesia, Intra Sudetic and Dobrudzha basins there is a marked increase in red-beds in these earliest Stephanian sequences. There has been relatively little work done on the depositional environments of these red-beds, but there is some evidence that they represent distinctly drier substrates (Besly, 1987, 1988). In the Gurkovo Formation in Dobrudzha, coals with fissures filled by quartz seem to be drying cracks that even developed in the swamps. The spread of more arid conditions may have been partly the result of the next widespread phase of tectonic activity, known as the Asturian Phase. Only in some of the intramontane basins did coal swamps return during middle and late Stephanian times, and then only briefly, probably in response to regional base-level changes that 
allowed lacustrine conditions to develop temporarily.

In Variscan Euramerica we therefore seem to be seeing the results of enhanced drainage of the wetland areas causing a change from lycopsid-dominated to mixed fern - lycopsid to fern-dominated vegetation. This better drainage may also explain the changes observed in the middle Asturian biotas preserved in the clastic substrates in those areas where the coal swamps were still developing: the enhanced diversity of the medullosaleans and marattialeans, the replacement of the lyginopteridalean scrambling and lianescent plants by callistophytaleans, and the changes to the sphenophylls and insects. However, the decline in abundance of the arborescent lycopsids affected the high transpiration rate - high rainfall feed-back cycle and the resulting reduction in precipitation affected peat-accumulation. This ultimately caused yet drier substrates to develop that became occupied mainly by conifers, cordaites and other seed-plants, and this will have further reduced precipitation.

Further west, in the coalfields of eastern and central USA, lycopsid-dominated coal swamps were able to survive for longer. In the Appalachian Coalfield, the level of the WestphalianStephanian boundary is equivocal depending on whether the macrofloral or palynological evidence is accepted at face value (Cleal et al., 2003), but it is likely to be no higher stratigraphically than the Upper Kittanning Coal, and may be as low as the Lower Kittanning Coal; either way, a significant part of the upper Allegheny Formation is of Cantabrian age. Further west again, in the stable, cratonic Illinois Basin, Cleal et al. (2003) concluded that the Westphalian-Stephanian boundary was within the Tradewater Formation, well below the Colchester (No. 2) Seam that yields the world-famous Mazon Creek biota, and thus the c. $350 \mathrm{~m}$ comprising the upper Tradewater Formation, and the entire Carbondale and Shelburn formations is of Cantabrian age (see also comments by Peppers, 1997, p. 243). Significantly, the lycopsids seemed to have remained the dominant component of the Asturian peat-substrate vegetation in the USA coal basins (Peppers, 1996) suggesting that poor drainage and high water tables conditions continued here far longer than in Variscan Euramerica; the middle Asturian epibole of Thymospora obscura that marks the expansion of marattialean-dominated vegetation into the peat substrate habitats in Europe cannot be identified in the USA palynofloras (Peppers, 1985, 1996). Except during maximum doming of some of the peat deposits (Eble \& Grady, 1993) the marattialeans do not start to make significant inroads into the USA coal basins until rather later, recognisable in the palynofloras by the start of the epibole of Thymospora pseudothiessenii (base of the CP Palynozone sensu Peppers, 1985, probably coincident with the base of the Cantabrian Substage - Cleal et al., 2003) although even here ferns comprise only $10-20 \%$ of the palynofloras of the clastic substrates (Peppers, 1997) and 10-20\% peat biomass in the coal ball floras (Phillips \& DiMichele, 1981; DiMichele \& Phillips, 1988, 2002). This epibole of T. pseudothiessenii is relatively short lived, and in both the Appalachians and Illinois basins lycopsids again become dominant in the stratigraphically highest Middle Pennsylvanian coals (Peppers, 1996; Eble et al., 2001). However, these youngest Middle Pennsylvanian coals are thinner and include more clastic partings than their stratigraphically-lower counterparts (DiMichele et al., 2009, p. 210), and the coal ball floras, although dominated by lycospids, contain a more diverse and structurally complex vegetation (DiMichele \& Phillips, 1994) suggesting the onset of profound changes to the coal swamp habitats.

Eventually, by the start of Late Pennsylvanian (probably equivalent to late Cantabrian) times, even in these westernmost parts of the Euramerican coal belt, most arborescent lycopsids had disappeared from the coal swamps. In many of the USA coal basins the Middle-Upper Pennsylvanian boundary where this change in the palynofloras and coal ball floras has been noted is a non-sequence (e.g. Heckel, 1991; Peppers, 1996; Wagner \& Lyons, 1997; Pfefferkorn et al., 2008). It is tempting, therefore, as in Variscan Euramerica, to link the abrupt demise of the arborescent lycopsids in these basins with tectonic instability and changes to drainage patterns, rather than climate change. However, evidence for a non-sequence at this stratigraphical level in the cratonic Illinois Basin is less clear; Wagner \& Lyons (1997) have argued that there is a successional break here, but the consensus among most American geologists is that there is not.

Could climate change have been the main trigger for the change in composition of the coal swamps, at least in the far west of the palaeotropical coal belt, as still argued by many American geologists? We have seen in Variscan Euramerica the progressive contraction and change in vegetational-dominance of the coal swamps during Asturian and Cantabrian times, and that this resulted in reduced precipitation that may well have accelerated the process of contraction. Although the initial shrinking of the coal swamps seems to have been caused by tectonic disruption to landscapes and drainage patterns, eventually the process could have become self-sustaining - as the total area of coal swamps got less, precipitation was reduced and so yet more coal swamps disappeared. By the time the coal swamps had shrunk to the remnant in Illinois and surrounding areas, the cycle of habitat-loss and reduction in precipitation may have become irreversible and would have continued without the necessity of tectonics disrupting the landscape and drainage patterns.

The evidence presented here is consistent with the model proposed by Cleal \& Thomas (2005) that the contraction of the coal swamps in late Moscovian times was at least partly responsible for a significant increase in global temperatures at the onset of Late Pennsylvanian times. Our data suggest that the tectonic instability in Variscan Euramerica caused a loss of c. $1,500 \times 10^{3} \mathrm{~km}^{2}$ of coal swamps over a time interval of c. 3.5 Ma (based on the time scale of Menning et al., 2005). Based on similar calculations and assumptions used by Cleal \& Thomas 
(2005), this alone could have been responsible for an annual increase of atmospheric $\mathrm{CO}_{2}$ of between 0.37 and $0.69 \mathrm{ppm}-$ more than enough to cause global warming. However, there is an additional complication here that Cleal \& Thomas (2005) did not factor into their calculations: the arborescent lycopsids that were the reason these swamps were such a major carbon sink may not always have dominated the Moscovian palaeotropical vegetation. DiMichele et al. (2009) have argued that for a significant part of the time these wetlands were dominated by a rather different type of vegetation that was slower-growing and favoured more seasonal climates, but that remains of the lycopsid-dominated vegetation are preferentially preserved. This was partly based on evidence from uppermost Moscovian sequences where the collapse of the coal swamp habitats had already started (DiMichele \& Aronson, 1992) or sequences from marginal, better-drained habitats (Lyons \& Darrah, 1989; Plotnick et al., 2008), which are not an especially good model for the coal swamps at their maximum development. Palynofloras from Moscovian clastic sequences (e.g. Marshall \& Smith, 1964; Peppers, 1997; Dimitrova \& Cleal, 2007) often contain c. $60 \%$ Lycospora suggesting that the lycopsids were a dominant part of the coal swamp vegetation, and unpublished work on the middle Westphalian clastic sequences of the Ruhr have yielded palynofloras that are more than 90\% Lycospora (K. Jasper, pers. comm., 2009). While the arborescent lycospids were clearly not the only plants growing in the middle Westphalian palaeotropical wetlands, they were clearly dominant at this time, and there is little evidence of significant climatic seasonality. Nevertheless, it is probably safer to use the lower estimate value for the loss of carbon sink due to the collapse of the coal swamps towards the end of Moscovian times, viz $=0.37 \mathrm{ppm} \mathrm{CO}_{2}$. Spread over 3.5 Ma this would have produced excessive climatic warming that would probably have caused the destruction of most life on Earth, so other compensatory sinks must have come in to play. Erosion of the rising Variscan Mountains may have absorbed substantial amounts of $\mathrm{CO}_{2}$; as may have the oceans, although there is, as far as we know limited empirical evidence of this. Growth of vegetation (the Paraca Floral Realm of Iannuzzi \& Pfefferkorn, 2002) in the newly-available southern high-latitude areas that had appeared after the melting of the Gondwana ice-sheet will also have resulted in some carbon capture. It seems unlikely, however, that such a substantial increase in carbon in the carbon cycle would be completely off-set by such compensatory sinks. An increase in levels of atmospheric $\mathrm{CO}_{2}$ with a corresponding increase in global temperatures would seem to have been unavoidable.

Such warming would be unlikely to have triggered the change in the vegetation in the westernmost coal swamps such as in Illinois. The lycopsids that were the framework ecomorphic plants of this vegetation were, after all, highly adapted to tropical wetlands and, unless temperatures reached extreme levels, for which there is little independent evidence, why would they not have managed to survive such changes, especially as they had little competition from other plant groups? Reduced precipitation would be a far more likely cause of such changes, as this would have affected substrate moisture, to which the lycopsids would have been much more susceptible.

Cleal \& Thomas (2005) argued that the warming resulting from the collapse of the coal swamp habitats also caused the Kasimovian interglacial identified in Gondwana (González, 1990; Fielding et al., 2008) and the marked change in vegetation seen in the northern middle-high palaeolatitudes of Angara (Durante, 1995, 2000). Global stratigraphical correlations of sufficient accuracy to confirm this link are still impossible and the idea is still based mainly on the similarity in the shapes of the curves of the extent of the coal forests and the polar icesheet, and of the northern hemisphere vegetation change. However, Horton \& Poulsen (2009) have estimated that removal of the polar ice-sheet could have been achieved by an increase in atmospheric $\mathrm{CO}_{2}$ of 2,240 ppm, levels which were approached in Late Pennsylvanian times according to the compilation by Royer et al. (2009), and which based on our figures could have been achieved in $10^{4}$ years through the loss of coal swamps in Variscan Euramerica alone. It is of course possible that the concurrent decline in the coal swamps in Variscan Euramerica and the contraction of the polar ice sheet was coincidental another 'conflation of correlation with causation' sensu DiMichele et al. (2009). However, if the warming that caused the polar ice sheet to contract was not due to the loss of carbon sink represented by the coal swamps of Variscan Euramerica, what was it caused by? This is not to say that deglaciation in Gondwana had no effect on precipitation in the palaeotropics; Peyser \& Poulsen (2008) have suggested that a contracting polar ice-sheet would have weakened the southern Hadley Cell, which would in turn have reduced levels of precipitation in low latitudes (see also Poulsen et al., 2007). However, in the absence of any convincing alternative explanation as to why the Gondwana ice-sheet contracted, it seems more likely that its effects were to re-enforce the changes that were taking place in the tropical latitudes, rather than initiating those changes.

In conclusion, our results go counter to the widely-held idea that the coal swamps underwent an abrupt change at the Middle-Late Pennsylvanian boundary, mainly triggered by climate change. This latter view was largely the result of focussing mainly on the evidence from the far west of the Euramerican coal belt and then extrapolating the results across the rest of that coal belt. When the wider picture is examined it becomes clear that the events in these westernmost areas were merely the culmination of a more protracted process lasting perhaps 3-4 million years during late Bolsovian to Cantabrian times, where the swamps progressively contracted and changed in vegetational composition (Fig. 52). The process involved an accelerating feedback-loop between changing vegetation, declining precipitation and contracting swamps, initiated by the tectonically-driven landscape and drainage 


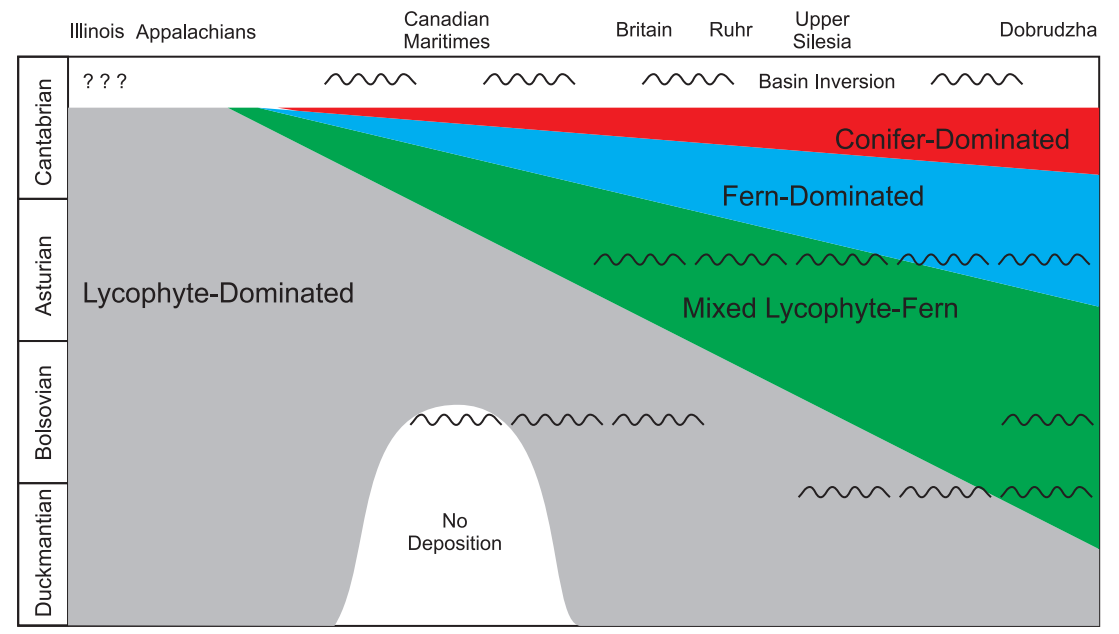

Fig. 52. A diagrammatic representation of how the coal swamps progressively changed in composition during late Westphalian and early Stephanian times across the forland areas of Euramerica. The undulating lines represent periods of tectonic instability. The horizontal scale represents the approximate distances between the basins.

changes that occurred in Variscan Euramerica, although eventually gaining a momentum of its own allowing it eventually to engulf even the tectonically more quiescent cratonic areas. Pfefferkorn et al. (2008) maintain that climate was the main driving mechanism behind these changes as in the modern-day world climate is the primary control on plant distribution. Climate clearly was part of the story but, as pointed out by DiMichele et al. (2009), care has to be taken when using modern analogues to interpret past system behaviour. In the case of the Moscovian coal swamps, the bizarre biology of the arborescent lycopsids that dominated the vegetation (Phillips \& DiMichele, 1992) surely makes any simplistic comparison with modern-day vegetation ecology and biogeography unsafe. The exceptional vulnerability of their rooting structures surely made these plants far more susceptible to changes in drainage patterns and substrates than to changes in climate (Calder, 1993; Kerp, 1996, p. 269). Reduced precipitation in the palaeotropical belt might eventually have produced changes to the substrates that could also have caused the coal swamps to contract, maybe initiated by the onset of interglacial conditions and the weakening of the Hadley Cell, but then what caused the climate to warm? In contrast, the evident correlation of tectonic activity in Variscan Euramerica with changes to drainage and substrates surely provides a more plausible explanation of causality for the collapse of the coal swamp habitats (unless one is going to invoke the unlikely explanation that the changes to drainage and substrates caused the tectonism). It is not meant by this the simple disruption of the coal swamps by the uplift of the Central Pangaea Mountains causing a rain-shadow effect as suggested by Rowley et al. (1985) or Ziegler et al. (1997); as pointed out by Cleal \& Thomas (2005) the relative detailed timing of events does not really bear this out (see also Peyser \& Poulsen, 2008). Rather we see tectonic instability across Variscan Euramerica as progressively disrupting the habitats there favoured by the lycopsids, and this eventually caused changes that spread across the entire Euramerican coal belt.

\section{Final remarks}

We set out at the start of this study to draw together all of the available evidence to document the changes that took place in terrestrial habitats and biotas during late Moscovian times. What we have been able to develop from this is a coherent model of a coal swamp habitat that progressively shrank and changed in composition over a period of perhaps $4 \mathrm{Ma}$, partly through landscape instability resulting from Variscan tectonic activity, and partly through reductions in rainfall itself caused by the change from lycopsid- to fern-dominated vegetation. In a way, therefore, both Gastaldo et al. (1996) and Cleal \& Thomas (2005) were correct: both climate change and tectonics were in part responsible for the demise of the coal swamps during late Moscovian times. The important point, however, is that although the final denouement of the arborescent lycopsid story in Euramerica may have been the result of a change in climate, the overall process was initiated and for a long time sustained by tectonic activity.

At the start, we had assumed that as so much data was available for the coal swamps of Variscan Euramerica that the study would mainly be about data collation, rather than data generation. The amount of data available was indeed substantial and has allowed us to develop the basics of a coherent model. However, the study has also revealed substantial gaps in our knowledge, especially concerning the detailed distributions of many biotic groups. The pteridosperms are fairly well understood, although there remain a number of basins where taxonomic revisions are still needed. Ferns, sphenophylls and lycopsids have also been extensively recorded but there remain substantial issues to be resolved surrounding the definition of species, with obvious consequences for the use of these fossils for palaeobiogeographical or biostratigraphical analyses. Cordaites have recently been shown to be impossible to identify accurately without cuticle studies (Šimůnek, 2007b), which is clearly a subject that is ripe for extensive study. And sphenophyte taxonomy has been virtually ignored in recent years and they remain the 'Cinderella' group in these floras. 
The potential of palynology as a tool for determining general patterns of vegetation change in the coal swamps has been shown by several recent studies (Dimitrova et al., 2005, in press; Dimitrova \& Cleal, 2007; Cleal et al., 2007) but there remain many areas where similar studies are needed, such as the British basins, Saar-Lorraine, Upper Silesia and the Bohemian Massif. The invertebrate faunas are problematic as the records are so sparse and disparate, but the centralised collation of the data (e.g. the EDNA project for insects) may start revealing significant patterns. And, although they have not been dealt with in this study, the distribution of freshwater faunas, notably the bivalves and fishes, may prove an invaluable tool for helping resolve the changing habitats in the coal swamps.

As well as providing additional evidence of the interaction of tectonics, vegetation and climate in late Moscovian times, IGCP 469 has been important for bringing together an active team of specialists to study these changes. Moreover, it has provided a blueprint for future studies in a field that is becoming increasingly relevant, dealing as it does with the only pre-Neogene time when we can follow the interaction between climate, atmosphere and vegetation in a world that bears at least some similarities to that which we live in today. This is undoubtedly an exciting time to be studying the environments and biotas of the Pennsylvanian coal swamps, with still much to be discovered.

\section{Acknowledgements}

This study was part of the International Geoscience Programme (IGCP Project 469), and we are grateful to IUGS and UNESCO for the financial and operational support that we have received. In particular, we would like to thank Dr Margarete Patzak UNESC0, Paris) for her support and practical advice during the project. Financial support for the project has also been received from the Royal Society and the Geological Society (London, UK), the National Museum Wales (Cardiff, UK), the TNO Geological Survey (Utrecht, the Netherlands), and the Grant Agency of Czech Republic (205/07/1059). For providing facilities during the various IGCP 469 meetings, we thank the University of Utrecht, the IUGS Subcommission on Carboniferous Stratigraphy, Geological Institute (Sofia), National Museum Wales (Cardiff), Dalhousie University (Halifax, Nova Scotia), University of Bucharest (especially to Dr Mihai Popa), Geological Institute (Kraków), Czech Academy of Sciences (Prague), University of Birmingham and Naturalis (Leiden). For help during the development of the EDNA palaeoentomological database, thanks go to the Geological Society of London, the Linnean Society, Dr Mark Sutton (Imperial College, London/Palaeontological Association) and Mr Tony Mitchell (Maidstone Museum). Finally, we would like to express our considerable gratitude to Dr Henk Kombrink (TNO Geological Survey, Utrecht) for his highly constructive and helpful review of this report.

\section{References}

Abbink, 0.A., 2003. Palynological re-study of well Kemperkoul-1. Mededelingen Rijks Geologische Dienst 44-4: 1-19.

Abbott, M.L., 1958. The American species of Asterophyllites, Annularia and Sphenophyllum. Bulletin of American Paleontology 38: 289-390.

Aitkenhead, N., Barclay, W.J., Brandon, A., Chadwick, R.A., Chisolm, J.I., Cooper, A.H. \& Johnson, E.W., 2002. British Regional Geology: The Pennines and adjacent areas ( $4^{\text {th }}$ edition). British Geological Survey (Keyworth): $206 \mathrm{pp}$.

Arber, E.A.N., 1912. The fossil plants of the Forest of Dean Coalfield. Proceedings of the Cotteswold Natural Field Club 17: 321-332.

Arber, E.A.N., 1913. On the Fossil Floras of the Wyre Forest, with special reference to the geology of the coalfield and its relationships to the neighbouring Coal measure areas. Transactions of the Royal Society, London 204: 363-445.

Arber, E.A.N., 1916. On the fossil floras of the Coal Measures of South Staffordshire. Transactions of the Royal Society, London 208: 127-155.

Arens, N.C., 1997. Responses of leaf anatomy to light environment in the tee fern Cyathea caracasana (Cyatheaceae) and its application to some ancient seed ferns. Palaios 12: 84-94.

Arillo, A., Braukmann, C., Béthoux, 0. \& Schneider, J.W., 2007. Fossil insects from the Carboniferous of (the) Iberian Peninsula. In: Abstract Book Fossils x3. Vitoria-Gasteiz (Provincial Council of Álava): 198.

Arthaud, F. \& Matte P., 1977. Late Paleozoic strike-slip faulting in southern Europe and northern Africa: result of a right-lateral shear zone between the Appalachians and the Urals. Geological Society of America Bulletin 88: $1305-1320$

Baker, R.A. \& DiMichele, W.A., 1997. Biomass allocation in Late Pennsylvanian coal-swamp plants. Palaios 12: 127-132.

Barthel, M., 1962a. Mikropaläontologische Untersuchungen im Rotliegenden des Döhlener Beckens. Jahrbuch des Staatlichen Museums für Mineralogie und Geologie zu Dresden 1962: 157-175

Barthel, M., 1962b. Zur Kenntnis inkohlter Blätter der Gattung Cordaites Presl. Hallesches Jahrbuch für Mitteldeutsche Erdgeschichte 4: 37-39.

Barthel, M., 1964. Coniferen- und Cordaiten-Reste aus dem Rotliegenden des Döhlener Beckens. Geologie 13: 60-89.

Barthel, M., 1976. Die Rotliegendflora Sachsens. Abhandlungen des Staatlichen Museums für Geologie und Mineralogie zu Dresden 24: 1-190.

Barthel, M., 1997. Epidermal structures of sphenophylls. Review of Palaeobotany and Palynology 95: 115-127.

Barthel, M., 2004. Die Rotliegendflora des Thüringer Waldes. Teil 2: Calamites und Lepidophyten. Veröffentlichungen Naturhistorisches Museum Schleusingen 19: 19-48.

Bashforth, A.R., 2005. Late Carboniferous (Bolsovian) macroflora from the Barachois Group, Bay St. George Basin, southwestern Newfoundland, Canada. Palaeontographica Canadiana 24: 1-123.

Bashforth, A.R. \& Zodrow, E.L., 2007. Partial reconstruction and palaeoecology of Sphenophyllum costae (Middle Pennsylvanian, Nova Scotia, Canada). Bulletin of Geosciences 82: 365-382.

Batenburg, L.H., 1977. The Sphenophyllum species in the Carboniferous Flora of Holz (Westphalian D, Saar Basin, Germany). Review of Palaeobotany and Palynology 24: 69-99.

Beall, B.S., 1991. The Writhlington phalangiotarbids: their palaeobiological significance. Proceedings of the Geologists' Association 102: 161-168. 
Becq-Giraudon J.F., Montenat, Ch. \& Van den Driessche, J., 1996. Hercynian high-altitude phenomena in the French Massif Central: the tectonic implications. Palaeogeography, Palaeoclimatology, Palaeoecology 122: 227-241.

Beerling, D., 2007. The emerald planet - how plants changed Earth's history. 0xford University Press: 304 pp.

Bek, J., 1996. Carboniferous fertile branch Sporangiostrobus feistmantelii (0. Feistmantel) Němejc and its miospores from the Kladno Basin, Bohemian Massif. Acta musei Nationalis Pragae. Series B. Historia Naturalis 51: 37-51.

Bek, J. \& Opluštil, S., 1998. Some lycopsid, sphenopsid and pteropsid fructifications and their miospores from the Upper Carboniferous basins of the Bohemian Massif. Palaeontographica, Abteilung B 248: 127-161.

Bek, J. \& Opluštil, S., 2004. Palaeoecological constraints of some Lepidostrobus cones and their parent plants from the Late Palaeozoic continental basins of the Czech Republic. Review of Palaeobotany and Palynology 131: 49-89.

Bek, J., Opluštil, S. \& Drábková, J., 2001. Two species of Selaginella cones and their spores from the Bohemian Carboniferous continental basins of the Czech Republic. Review of Palaeobotany and Palynology 114: 57-81.

Belcher, C.M. \& McElwain, J.C., 2008. Limits for combustion in low $0_{2}$ redefine palaeoatmospheric predictions for the Mesozoic. Science 321, 1197-1200 (plus erratum).

Bell, W.A., 1938. Fossil flora of Sydney Coalfield, Nova Scotia. Canada Department of Mines and Resources, Geological Survey Memoir 215: 1-334.

Bell, W.A., 1940. The Pictou Coalfield, Nova Scotia. Canada Department of Mines and Resources, Geological Survey Memoir 225: 1-161.

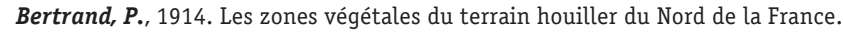
Leur extension verticale par rapport aux horizons marins. Annales de la Société géologique du Nord 43: 208-254.

Bertrand, P., 1919. Les zones végétales du terrain houiller du Nord de la France. Compte rendu de l'Académie des Sciences, Paris 168: 780-782.

Bertrand, P., 1926. La zone à Mixoneura du Westphalien supérieur. Compte rendu de l'Académie des Sciences, Paris 183: 1349-1350.

Bertrand, P., 1937. Tableux des flores successives du Westphalien supérieur et du Stéphanien. Compte rendu Deuxième Congrès pour l'Avancement des Études de Stratigraphie Carbonifère (Heerlen, 1935) 1: 67-79.

Besly, B.M., 1987. Sedimentological evidence for Carboniferous and Early Permian palaeoclimates of Europe. Annales de la Societe Géologique du Nord 106: 131-143.

Besly, B.M., 1988. Palaeogeographic implications of late Westphalian to early Permian red-beds, Central England. In: Besly, B. \& Kelling, G. (eds): Sedimentation in a synorogenic basin complex, the Upper Carboniferous of northwest Europe. Blackie (London): 200-221.

Besly, B.M., 2005. Late Carboniferous red-beds of the UK southern North Sea viewed in a regional context. In: Collinson, J.D., Evans, D.J., Holliday, D.W. \& Jones, N.S. (eds): Carboniferous hydrocarbon resources: the southern North Sea and surrounding areas. Occasional Special Publication of the Yorkshire Geological Society 7: 225-226.

Besly, B.M., Burley, S.D. \& Turner, P., 1993. The late Carboniferous 'Barren Red bed' play of the Silver Pit area, Eouthern North Sea. In: Parker, J.R. (ed.): Petroleum Geology of Northwest Europe: Proceedings of the $4^{\text {th }}$ Conference: 727-740.
Besly, B.M. \& Cleal, C.J., 1997. Upper Carboniferous stratigraphy of the West Midlands (UK) revised in the light of borehole geophysical logs and detrital compositional suites. Geological Journal 32: 85-118.

Besly, B.M. \& Fielding, C.R., 1989. Palaeosols in Westphalian coal-bearing and red-bed sequences, central and northern England. Palaeogeography, Palaeoclimatology, Palaeoecology 70: 303-330.

Besly, B.M. \& Turner, P., 1983. Origin of red beds in a moist tropical climate (Etruria Formation, Upper Carboniferous, UK). In: Wilson, R.C.L. (ed.): Residual deposits. Special Publications of the Geological Society, London 11: 131-147.

Béthoux, 0. \& Jarzembowski, E.A., in press. New basal neopterans from Writhlington (UK, Pennsylvanian). Alavesia.

Binney, E.W., 1871. Observations on the structure of fossil plants found in Carboniferous strata. Part II. Lepidostrobus and some allied cones. Palaeontographical Society (London).

Blake, B.M., Cross, A.T., Eble, C.F., Gillespie, W.H., \& Pfefferkorn, H.W., 2002. Selected plant megafossils from the Carboniferous of the Appalachian Region, eastern United States: geographic and stratigraphic distribution. In: Carboniferous and Permian of the world. Proceedings of the XIV International Congress on Carboniferous and Permian stratigraphy, Calgary, Alberta, Canada August 17-21, 1999. Canadian Society of Petroleum Geologists Memoir 19: 259-335.

Bless M.J.M., Bouckaert, J. \& Paproth, E., 1989. The Dinant nappes: a model of tensional listric faulting inverted into compressional folding and thrusting. Bulletin de la Société belge de Gólogie 98: 221-230.

Boehner, R.C. \& Giles, P.S., 1986. Geological map of the Sydney Basin. Nova Scotia Department of Mines and Energy, Halifax NS (Map 86-1).

Bolton, H., 1912. Insect remains from the Midland and South-Eastern Coal Measures. Quarterly Journal of the Geological Society of London 68: 310-323.

Bolton, H., 1924. On a new form of blattoid from the Coal Measures of the Forest of Dean. Quarterly Journal of the Geological Society of London 80: 17-21.

Bossowski, A., Ihnatowicz, A., Mastalerz, K., Kurowski, L. \& Nowak, G.J., 2005. Intra-Sudetic depression. In: Zdanowski, A. \& Źakowa H. (eds): The Carboniferous System in Poland. Prace Państwowego Instytutu Geologicznego 148: $142-147$.

Boureau, E., 1964. Traité de Paléobotanique III. Sphenophyta, Noeggerathiophyta. Masson et Cie (Paris): $544 \mathrm{pp}$.

Braddy, S.J., Poschmann, M. \& Tetlie, O.E., 2008. Giant claw reveals the largest ever arthropod. Biology Letters 4: 106-109.

Brongniart, A., 1822. Sur la classification et la distribution des végétaux fossiles en général, et sur ceux des terrains de sediment supérieur en particulier. Mémoires du Museum d'Histoire Naturelle, Paris 8: 203-240, 297-348, pls 12-17.

Brousmiche, C., 1983. Les fougères sphénoptéridiennes du bassin houiller SarroLorrain. Publication Société Géologique du Nord 10: 1-480.

Buisine, M., 1961. Contribution a l'étude de la flore du terrain houiller. Les Aléthoptéridées du Nord de la France. Études Géologiques pour l'Atlas Topographie Souterraine 1(4): 1-317.

Buła, Z. \& Żaba, J., 2005. Pozycja tektoniczna Górnośląskiego Zagłębia Węglowego na tle prekambryjskiego i dolnopaleozoicznego podłoża. In: Jureczka, J., Buła, Z. \& Żaba, J. (eds): LXXVI Zjazd Naukowy Polskiego Towarzystwa Geologicznego: $14-42$.

Burek, C.V. \& Cleal, C.J., 2005. The life and work of Emily Dix (1904-1972). In: Bowden, A.J., Burek, C.V. \& Wilding, R. (eds): History of palaeobotany: selected essays. Geological Society of London, Special Publication 241: 181-196. 
Burger, K., 1990. Vulkanogene Glasscherben-Relikte in Kohlentonsteinen des Saar-Lothringer Oberkarbons sowie Herkunft und Menge der Pyroklastika. Geologische Rundschau 79: 659-691.

Burger, K., Bieg, G. \& Pfisterer, W., 2005. Klassische und primitive KaolinKohlentonsteine im Ruhroberkarbon. In: Deutsche Stratigraphische Kommission (ed.): Stratigraphie von Deutschland. - Das Oberkarbon (Pennsylvanium) in Deutschland. Courier Forschungsinstitut Senckenberg 254: 169-180.

Burger, K. \& Billig, M., 1987. Vulkanogene Glasscherbenrelikte im Kohlentonstein 3 des Saar-Lothringer Oberkarbons. Zeitschrift der Deutschen Geologischen Gesellschaft 138: 103-119.

Burger, K., Hess, J.C. \& Lippolt, H.J., 1997. Tephrochronologie mit KaolinKohlentonsteinen: Mittel zur Korrelation paralischer und limnischer Ablagerungen des Oberkarbons. Geologisches Jahrbuch, A 147: 3-39.

Burgess, P.M. \& Gayer, R.A., 2000. Late Carboniferous tectonic subsidence in South Wales: implications for Variscan basin evolution and tectonic history in SW Britain. Journal of the Geological Society, London 157: 93-104.

Butterfield, N.J., 2009. 0xygen, animals and oceanic ventilation; an alternative view. Geobiology 7: 1-7.

Butterworth, M.A. \& Smith, A.H.V., 1976. The age of the British Upper Coal Measures with reference to their miospore content. Review of Palaeobotany and Palynology 22: 281-306.

Calder, J.H., 1993. The evolution of a ground-water-influenced (Westphalian B) peat-forming ecosystem in a piedmont setting: the No. 3 seam, Springhill coal, Cumberland Basin, Nova Scotia. In: Cobb, C.J. \& Cecil, C.B. (eds): Modern and ancient coal-forming environments. Special Papers, Geological Society of America 286: 153-180.

Calder, J.H., 1998. The Carboniferous evolution of Nova Scotia. In: Blundell, D. J. \& Scott, A.C. (ed.): Lyell: the past is the key to the present. Geological Society of London, Special Publications 143: 261-302.

Calder, J.H., Gibling, M.R., Eble, C.F., Scott, A.C. \& Macneil, D.J., 1996. The Westphalian D fossil lepidodendrid forest at Table Head, Sydney Basin, Nova Scotia: sedimentology, paleoecology and floral response to changing edaphic conditions. International Journal of Geology 31: 277-313.

Calver, M.A., 1968. Distribution of Westphalian marine faunas in northern England and adjoining areas. Proceedings of the Yorkshire Geological Society 37: 1-72.

Calver, M.A., 1969. Westphalian of Britain. Compte rendu, Sixiéme Congres International de Stratigraphie et de Géologie du Carbonifére (Sheffield, 1967) 1: 233-254.

Cameron, T.D.J., 1993. Carboniferous and Devonian (southern North Sea). In: Knox, R.W.O'B. \& Cordey, W.G. (eds): Lithostratigraphic Nomenclature of the UK North Sea 5: 1-193.

Carpenter, F.M., 1992. Superclass Hexapoda. In: Treatise on Invertebrate Paleontology, Part R, Arthropoda 4 (3 \& 4). Boulder (Geological Society of America) and Lawrence (University of Kansas): 655 pp.

Casshyap, S.M., 1975. Cyclic characteristics of coal-bearing sediments in the Bochumer Formation, Ruhrgebiet, Germany. Sedimentology 22: 237-255.

Castro, M.P., 1997. Huellas de actividad biológica sobre plantas del Estefaniense superior de La Magdalena (León, España). Revista Española de Paleontología 12: 52-66.

Chisholm, J.I., 1990. The Upper Band-Better Bed sequence (Lower Coal Measures, Westphalian A) in the central and south Pennine area of England. Geological Magazine 127: 55-74.
Chisholm, J.I., Waters, C.N., Hallsworth, C.R., Turner, N., Strong, G.E. \& Jones, G.S., 1996. Provenance of Lower Coal Measures around Bradford, West Yorkshire. Proceedings of the Yorkshire Geological Society 51: 153-166.

Clayton, G., Coquel, R., Doubinger, J., Gueinn, K.J., Loboziak, S., Owens, B. \& Streel, M., 1977. Carboniferous miospores of western Europe: illustration and zonation. Mededelingen Rijks Geologische Dienst 29: 1-71.

Cleal, C.J., 1978. Floral biostratigraphy of the upper Silesian Pennant Measures of South Wales. Geological Journal 13: 165-194.

Cleal, C.J., 1984a. The Westphalian D floral biostratigraphy of Saarland (Fed. Rep. Germany) and a comparison with that of South Wales. Geological Journal 19: 327-351.

Cleal, C.J., 1984b. The recognition of the base of the Westphalian D Stage in Britain. Geological Magazine 121: 125-129.

Cleal, C.J., 1986. Fossil plants of the Severn Coalfield and their biostratigraphical significance. Geological Magazine 123: 553-568.

Cleal, C.J., 1987. Macrofloral biostratigraphy of the Newent Coalfield, Gloucestershire. Geological Journal 22: 207-217.

Cleal, C.J., 1991a. The age of the base of the Forest of Dean Coal Measures: fact and fancy. Proceedings of the Geologists' Association 102: 261-264.

Cleal, C.J., 1991b. Plant fossils in geological investigation: the Palaeozoic. Ellis Horwood (Chichester): $233 \mathrm{pp}$.

Cleal, C.J., 1997. The palaeobotany of the upper Westphalian and Stephanian of southern Britain and its geological significance. Review of Palaeobotany and Palynology 95: 227-253.

Cleal, C.J., 1999. Plant macrofossil biostratigraphy. In: Jones, T.P. \& Rowe, N.P (eds): Fossil plants and spores: modern techniques. Geological Society, London: 220-224.

Cleal, C.J., 2004. IGCP 469 Late Westphalian terrestrial biotas and environments of the Variscan Foreland and adjacent intramontane basins. Geologica Balcanica 34: 3-10.

Cleal, C.J., 2005. The Westphalian macrofloral record from the cratonic central Pennines Basin, UK. Zeitschrift der Deutschen Gesellschaft für Geowissenschaften 156: 387-410.

Cleal, C.J., 2007. The Westphalian-Stephanian macrofloral record from the South Wales Coalfield. Geological Magazine 144: 465-486.

Cleal, C.J., 2008a. IGCP 469 Late Variscan terrestrial biotas and palaeoenvironments. Studia Geologica Polonica 129: 7-8.

Cleal, C.J., 2008b. Macrofloral biostratigraphy of the Ottweiler Group in SaarLorraine and its consequences for Stephanian palynostratigraphy and geochronology. Studia Geologica Polonica 129: 9-23.

Cleal, C.J., 2008c. Plant biostratigraphy and biodiversity-changes in the Westphalian-Stephanian of the southern Pennines Basin, UK. Studia Geologica Polonica 129: 24-41.

Cleal, C.J., 2008d. Palaeofloristics of Middle Pennsylvanian lyginopteridaleans in Variscan Euramerica. Palaeogeography, Palaeoclimatology, Palaeoecology 261: 1-14.

Cleal, C.J., 2008e. Palaeofloristics of Middle Pennsylvanian medullosalens in Variscan Euramerica. Palaeogeography, Palaeoecology, Palaeoclimatology 268: 164-180.

Cleal, C.J., Dimitrova, T.Kh. \& Zodrow, E.L., 2003. Macrofloral and palynological criteria for recognising the Westphalian-Stephanian boundary. Newsletters on Stratigraphy 39: 181-208. 
Cleal, C.J., James, R.M. \& Zodrow, E.L., 1999. Variation in stomatal density in the Late Carboniferous gymnosperm frond Neuropteris ovata. Palaios 14: 180-185.

Cleal, C.J. \& Shute, C.H., 1995. A synopsis of neuropteroid foliage from the Carboniferous and Lower Permian of Europe. Bulletin of the British Museum (Natural History), Geology Series 51: 1-52.

Cleal, C.J. \& Shute, C.H., 2003. Systematics of the Late Carboniferous medullosalean pteridosperm Laveineopteris and its associated Cyclopteris leaves. Palaeontology 46: 353-411.

Cleal, C.J., Tenchov, Y.G., Dimitrova, T.Kh., Thomas, B.A. \& Zodrow, E.L., 2007. Late Westphalian-Early Stephanian vegetational changes across the Variscan Foreland. In: Wong, Th. E (ed.): Proceedings of the $\mathrm{XV}^{\text {th }}$ International Congress on Carboniferous and Permian Stratigraphy. Utrecht, the Netherlands, 10-16 August 2003. Royal Netherlands Academy of Arts and Sciences (Amsterdam): 367-377.

Cleal, C.J., Tenchov, Y. \& Zodrow, E.L., 2004. Review of the late Westphalian early Stephanian macrofloras of the Dobrudzha Coalfield, Bulgaria. Geologica Balcanica 34: 11-20.

Cleal, C.J. \& Thomas, B.A., 1992. Lower Westphalian D fossil plants from the Nolton-Newgale Coalfield, Dyfed, Great Britain. Geobios 25: 315-322.

Cleal, C.J. \& Thomas, B.A., 1994. Plant fossils of the British Coal Measures. Palaeontological Association (London): $222 \mathrm{pp}$.

Cleal, C.J. \& Thomas, B.A., 1995. British Upper Carboniferous stratigraphy. Geological Conservation Review Series, No. 11. London (Chapman \& Hall): $295 \mathrm{pp}$.

Cleal, C.J. \& Thomas, B.A., 1999. Tectonics, tropical forest destruction and global warming in the Late Palaeozoic. Acta Palaeobotanica, Supplement 2: 17-19.

Cleal, C.J. \& Thomas, B.A., 2005. Palaeozoic tropical rainforests and their effect on global climates: is the past the key to the present? Geobiology 3: 13-31.

Cleal, C.J., Zodrow, E.L. \& Šimůnek, Z., 2007. Leaf cuticles from the Pennsylvanian-aged medullosalean Odontopteris cantabrica Wagner. Acta Palaeobotanica 47: 327-337.

Cleal, C.J., Zodrow, E.L. \& Mastalerz, M., in press. An association of Alethopteris foliage, Trigonocarpus ovules and Bernaultia-like pollen organs from the Middle Pennsylvanian of Nova Scotia, Canada. Palaeontographica, Abteilung B.

Cole, J.M., Whitaker, M., Kirk, M. \& Crittenden, S., 2005. A sequence stratigraphical scheme for the Late Carboniferous, southern North Sea, Anglo-Dutch sector. In: Collinson, J.D., Evans, D.J., Holliday, D.W. \& Jones, N.S. (eds): Carboniferous hydrocarbon resources: the southern North Sea and surrounding areas. Occasional Special Publication of the Yorkshire Geological Society 7: 75-104.

Collinson, J.D., Jones, C.M., Blackbourn, G.A., Besly, B.M., Archard, G.M. \& MacMahon, A.H., 1993. Carboniferous depositional systems of the Southern North Sea. In: Parker, J.R. (ed.): Petroleum Geology of Northwest Europe: Proceedings of the $4^{\text {th }}$ Conference: 677-687.

Constanza, S.H., 1984. Morphology and systematics of Cordaites of Pennsylvanian coal swamps of Euramerica. PhD thesis, University of Illinois.

Cope, J.C.W., Guion, P.D., Sevastopulo, G.D. \& Swan, A.R.H., 1992. Carboniferous. In: A palaeogeographical atlas. Geological Society, London: 67-86.

Corsin, P., 1932. Guide paléontologique dans le Terrain Houiller du Nord de la France. Lille. Université de Lille, Travaux et Mémoires 5: 1-44.

Corsin, P., 1951. Bassin houiller de la Sarre et de la Lorraine, I. Flore Fossile me Fascicule Pécoptéridiées. Études des Gite Minéraux de la France: 370 pp.

Corsin, P., 1955. Positions systématique des Pécopteris. Comptes rendus de l'Académie des Sciences, Paris 240: 661-663.
Cowan, G., 1989. Diagenesis of Upper Carboniferous sandstones: southern North Sea Basin. In: Whateley, M.K.G. \& Pickering, K.T. (eds): Deltas: Sites and Traps for Fossil Fuels. Geological Society of London, Special Publication 41: 57-73.

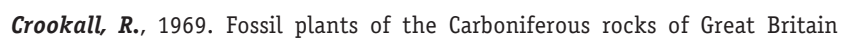
(Second Section). Part 5. Memoirs of the Geological Survey of Great Britain, Palaeontology 4: 573-792.

Crookall, R., 1970. Fossil plants of the Carboniferous rocks of Great Britain (Second Section). Part 6. Memoirs of the Geological Survey of Great Britain, Palaeontology 4: 793-840.

Daňková-Pokorná, S., 1952. Two new Sphenophylla from the lower grey beds of the coal basin of central Bohemia. Sborník Státního ústavu geologického 18: 297-307.

David, F., 1990. Sedimentologie und Beckenanalyse im Westfal C und D des nordwestdeutschen Beckens. DGMK-Bericht 384-3.

Davies, D., 1929. Correlation and palæontology of the Coal Measures in east Glamorganshire. Philosophical Transactions of the Royal Society of London, Series B 217: 91-153.

Davies, S.J. \& Gibling, M.R., 2003. Architecture of coastal and alluvial deposits in an extensional basin: the Carboniferous Joggins Formation of eastern Canada. Sedimentology 50: 1-25.

Dembowski, Z., 1972. Ogólne dane o Górnośląskim Zagłębiu Węglowym. Prace Instytutu Geologicznego (Warszawa) 61: 9-22.

Dettmann, M. E., 1963. Upper Mesozoic microfloras from south-eastern Australia. Proceedings of the Royal Society of Victoria 77: 1-148.

De Vos, W., 1997. Influence of the granitic batholith of Flanders on Acadian and later deformation (Brabant Massif, Belgium). Aardkundige Mededelingen 8: 49-52.

Diesel, C.F.K., 1992. Coal-bearing depositional systems. Berlin Heidelberg (Springer-Verlag): $721 \mathrm{pp}$.

DiMichele, W.A. \& Aronson, R.B., 1992. The Pennsylvanian-Permian vegetational transition: a terrestrial analogue of the onshore-offshore hypothesis. Evolution 46: 807-824.

DiMichele, W.A., Montañez, I.P., Poulsen, C.J. \& Tabor, N.J., 2009. Climate and vegetational regime shifts in the late Paleozoic ice age earth. Geobiology 7: 200-226.

DiMichele, W.A., Pfefferkorn, H.W. \& Gastaldo, R.A., 2001. Response of Late Carboniferous and Early Permian plant communities to climate change. Annual Review of Earth and Planetary Sciences 29: 461-487.

DiMichele, W.A., Pfefferkorn, H.W. \& Phillips, T.L., 1996. Persistence of Late Carboniferous tropical vegetation during glacially driven climatic and sealevel fluctuations. Palaeogeography, Palaeoclimatology, Palaeoecology 125: 105-128.

DiMichele, W.A. \& Phillips, T.L., 1988. Paleoecology of the Middle Pennsylvanianage Herrin Coal Swamp (Illinois) near a contemporaneous river system, the Walshville paleochannel. Review of Palaeobotany and Palynology 56: 151-176.

DiMichele, W.A. \& Phillips, T.L., 1994. Paleobotanical and paleoecological constraints on models of peat formation in the Late Carboniferous of Euramerica. Palaeogeography, Palaeoclimatology, Palaeoecology 106: 39-90.

DiMichele, W.A. \& Phillips, T.L., 1985. Arborescent lycopod reproduction and paleoecology in a coal-swamp environment of late Middle Pennsylvanian age (Herrin Coal, Illinois, U.S.A.). Review of Palaeobotany and Palynology 44: 1-26. 
DiMichele, W.A. \& Phillips, T.L., 1994. Paleobotanical and paleoecological constraints on models of peat formation in the Late Carboniferous of Euramerica. Palaeogeography, Palaeoclimatology, Palaeoecology 106: 39-90.

DiMichele, W.A. \& Phillips, T.L., 1995. The response of hierarchially structured ecosystems to long-term climatic change: a case study using tropical peat swamps of Pennsylvanian age. In: Stanley, S.M., Knoll, A.J. \& Kennett, J.P. (eds): Effects of past global change on life. Studies in Geophysics, National Academy of Sciences (Washington DC): 134-155.

DiMichele, W.A. \& Phillips, T.L., 1996a. Climate change, plant extinction and vegetational recovery during Middle-Late Pennsylvanian transition: the case of tropical peat-forming environments in North America. In: Hart, M.B. (ed.): Biotic recovery from mass extinction events. Geological Society (London): 201-221.

DiMichele, W.A. \& Phillips, T.L., 1996b. Clades, ecological amplitudes, and ecomorphs: phylogenetic effects and persistence of primitive plant communities in the Pennsylvanian-age tropical wetlands. Palaeogeography, Palaeoclimatology, Palaeoecology 127: 83-105.

DiMichele, W.A. \& Phillips, T.L., 2002. The ecology of Paleozoic ferns. Review of Palaeobotany and Palynology 119: 143-159.

DiMichele, W.A., Phillips, T.L. \& McBrinn, G.E., 1991. Quantitative analysis and paleoecology of the Secor Coal and roof-shale floras (Middle Pennsylvanian, Oklahoma). Palaios 6: 390-409.

DiMichele, W.A., Phillips, T.L. \& Peppers, R.A., 1985. The influence of climate and depositional environment on the distribution and evolution of Pennsylvanian coal swamp plants. In: Tiffney, B. (ed.): Geological Factors in the Evolution of Plants. Yale University Press (New Haven CT): 223-256.

DiMichele, W.A., Phillips, T.L. \& Pfefferkorn, H.W., 2006. Paleoecology of Late Paleozoic pteridosperms from tropical Euramerica. Journal of the Torrey Botanical Society 133: 83-118.

Dimitrova, T.Kh., 1997. Palinolozhki ansambli ot Makedonskata svita, Dobrudzhanski vaglishten baseyn. Review of the Bulgarian Geological Society 58: 25-30.

Dimitrova, T.Kh. \& Cleal, C.J., 2007. Palynological evidence for late Westphalian - early Stephanian vegetation change in the Dobrudzha Coalfield, NE Bulgaria. Geological Magazine 144: 513-524.

Dimitrova, T.Kh., Cleal, C.J. \& Thomas, B.A., 2005. Palynology of late Westphalian - early Stephanian coal-bearing deposits in the eastern South Wales Coalfield. Geological Magazine 142: 809-821.

Dimitrova, T.Kh., Zodrow, E.L., Cleal, C.J. \& Thomas, B.A., in press. Palynological evidence for Pennsylvanian (Late Carboniferous) vegetation change in the Sydney Coalfield, eastern Canada. Geological Journal.

Dix, E., 1931. The flora of the Upper Portion of the Coal Measures of North Staffordshire. Quarterly Journal of the Geological Society of London 77: 160-179.

Dix, E., 1934. The sequence of floras in the Upper Carboniferous, with special reference to South Wales. Transactions of the Royal Society of Edinburgh 57: 789-838.

Dix, E., 1937. The succession of fossil plants in the South Wales Coalfield with special reference to the existence of the Stephanian. Compte rendu, $2^{\mathrm{e}}$ Congrès Stratigraphie du Carbonifère (Heerlen, 1935) 1: 159-184.
Doktor, M. \& Gradziński, R., 2000. Sedimentary environments and depositional systems of coal bearing succession of the Upper Silesian Coal Basin. Proceedings of XXIII Symposium Geology of Coal-Bearing Strata of Poland, 29-33. (In Polish, with English summary).

Donsimoni, M., 1981. Le bassin houiller lorrain: synthése géologique. Mémoires Bureau de Recherches Géologique et Minières 117: 1-99.

Döring, H., Hoth, K. \& Kahlert, E., 1988. Gegenwärtiger Stand der litho- und sporostratigraphischen Gliederung des Zwickauer Siles. Freiberger Forschungshefte C 419: 18-29.

Drägert, K., 1964. Pflanzensoziologische Untersuchungen in den Mittleren Essener Schichten des nördlichen Ruhrgebietes. Forschungsberichte des Landes Nordrhein-Westfalens 1363: 1-295.

Dreesen, R., Bossiroy, D., Dusar, M., Flores, R.M. \& Verkaeren, P., 1995. Overview of the influence of syn-sedimentary tectonics and palaeo-fluvial systems on coal seam and sand body characteristics in the Westphalian C strata, Campine Basin, Belgium. In: Whateley, M.K.G. \& Spears, D.A. ( eds): European coal geology. Geological Society Special Publication 82: 215-232.

Drozdzewski, G., 1993. The Ruhr coal basin (Germany): structural evolution of an autochthonous foreland basin. International Journal of Coal Geology 23: 231-250.

Drozdzewski, G., 2005. Zur sedimentären Entwicklung des Subvariscikums im Namurium und Westfalium Nordwestdeutschlands. In: Deutsche Stratigraphische Kommission (ed.): Stratigraphie von Deutschland. - Das Oberkarbon (Pennsylvanium) in Deutschland. Courier Forschungsinstitut Senckenberg 254: 271-325.

Dunham, K.C., Poole, E.G., 1974. The Oxfordshire Coalfield. Journal of the Geological Society 130: 387-391.

Dunlop, J.A., 1994a. The Upper Carboniferous amblypygid from the Writhlington Geological Nature Reserve. Proceedings of the Geologists' Association 105: 245-250.

Dunlop, J.A., 1994b. The palaeobiology of the Writhlington trigonotarbid arachnid. Proceedings of the Geologists' Association 105: 287-296.

Durante, M.V., 1995. Reconstruction of Late Paleozoic climatic changes in Angaraland according to phytogeographic data. Stratigraphy and Geological Correlations 3: 123-133.

Durante, M.V., 2000. Global cooling in the middle Carboniferous. Newsletter on Carboniferous Stratigraphy 18: 31-32.

Durden, C., 1984a. North American provincial insect ages for the continental last half of the Carboniferous and first half of the Permian. Compte Rendu. Neuvième Congrès International de Stratigraphie et de Géologie du Carbonifère 2: 606-612.

Durden, C., 1984b. Carboniferous and Permian entomology of western North America. Compte Rendu. Neuvième Congrès International de Stratigraphie et de Géologie du Carbonifère 2: 81-89.

Durden, C., 2005. Digest Number 108, paleogeoarthropoda@yahoogroups.com.

Eagar, R.M.C., 2005. Non-marine and limnic bivalves. In: Deutsche Stratigraphische Kommission (ed.): Stratigraphie von Deutschland. - Das Oberkarbon (Pennsylvanium) in Deutschland. Courier Forschungsinstitut Senckenberg 254: 55-86.

Eagar, R.M.C. \& Belt, E.S., 2003. Succession, palaeoecology, evolution, and speciation of Pennsylvanian non-marine bivalves, Northern Appalchian Basin, USA. Geological Journal 38: 109-143. 
Easterday, C.R., 2005. Evidence for relative stability in terrestrial lowland faunas despite severe climatic change at the Middle-Upper Pennsylvanian (Carboniferous) transition of paleotropical Euramerica: quantitative comparison of Cemeterey Hill (Ohio) with fourteen penecontemporaneous Permo-Carboniferous Konservat-Lagerstaetten. PaleoBios 25 (Supplement 2): 40.

Eble, C.F., 2004. A Carboniferous icehouse: an international comparison of MidCarboniferous tropical floras and their response to global climatic change. Energeia 15: 2-4.

Eble, C.F. \& Grady, W.C., 1993. Palynologic and petrographic characteristics of two Middle Pennsylvanian coal beds and a probable modern analogue. In: Cobb, C.J. \& Cecil, C.B. (eds): Modern and ancient coal-forming environments. Special Papers, Geological Society of America 286: 119-138.

Eble, C.F., Greb, S.F. \& Williams, D.A., 2001. The geology and palynology of Lower and Middle Pennsylvanian strata in the Western Kentucky Coal Field. International Journal of Coal Geology 47: 189-206.

Edwards, D., 1998. Climate signals in Palaeozoic land plants. Philosophical Transactions of the Royal Society of London, Series B 353: 141-157.

Evans, J.A., Chisholm, J.I. \& Leng, M.J., 2001. How U-Pb detrital monazite ages contribute to the interpretation of the Pennine Basin infill. Journal of the Geological Society, London 158: 741-744.

Fabian, H.J., 1971. Das Oberkarbon im Untergrund von Nordwestdeutschland und dem angrenzenden Nordseebereich. Fortschritte in der Geologie von Rheinland und Westfalen 19: 87-100.

Falcon-Lang, H.J., 2003. Late Carboniferous tropical dryland vegetation in an alluvial-plain setting. Palaios 18: 197-211.

Falcon-Lang, H.J. \& Bashforth, A.R., 2004. Pennsylvanian uplands were forested by giant cordaitalean trees. Geology 32: 417-420.

Falke, H. \& Kneuper, G., 1972. Das Karbon in limnischer Entwicklung. Compte rendu $7^{\mathrm{e}}$ Congrès International de Stratigraphie et de Géologie du Carbonifère (Krefeld, 1971) 1: 49-67.

Fielding, C.R., 1984a. A coal depositional model for the Durham Coal Measures of NE England. Journal of the Geological Society 141: 919-931.

Fielding, C.R., 1984b. Upper delta plain lacustrine and fluviolacustrine facies from the Westphalian of the Durham coalfield, NE England. Sedimentology 31: 547-567.

Fielding, C.R., 1986. Fluvial channel and overbank deposits from the Westphalian of the Durham coalfield, NE England. Sedimentology 33: 119-140.

Fielding, C.R., 1987. Lower delta plain interdistributary deposits - an example from the Westphalian of the Lancashire Coalfield, northwest England. Geological Journal 22: 151-162.

Fielding, C.R., Frank, T.D., Birgenheier, L.P., Rygel, M.C., Jones, A.T. \& Roberts, J., 2008. Stratigraphic imprint of the Late Palaeozoic Ice Age in eastern Australia: a record of alternating glacial and nonglacial climate regime. Journal of the Geological Society, London 165: 129-140.

Fissunenko, O.P. \& Laveine, J.-P., 1984. Comparaison entre la distribution des principales espèces-guides végétales du Carbonifère moyen dans le bassin du Donetz (URSS) et les bassins du Nord-Pas-de-Calais et de Lorraine (France). Compte rendu $9 \mathrm{e}$ Congrès de Stratigraphie et de Géologie du Carbonifère (Washington and Urbana, 1979) 1: 95-100.

Florin, $\boldsymbol{R}_{\text {., }}$ 1938-1945. Die Koniferen des Oberkarbons und des unteren Perms. Palaeontographica, Abteilung B 85: 1-729.
Foster, D., Holliday, D.W., Jones, C.M., Owens, B. \&, Welsh, A., 1989. The concealed Upper Palaeozoic rocks of Berkshire and south 0xfordshire. Proceedings of the Geologists' Association 100: 395-407.

Foster, S.A., 1986. On the adaptive value of large seeds for tropical moist forest trees: a review and synthesis. Botanical Review 52: 260-299.

Frakes, L.A., Francis, J.E. \& Styktus, J.I., 1992. Climate modes of the Phanerozoic. Cambridge University Press (Cambridge): 274 pp.

Franke, W., 2000. The mid-European segment of the Variscides: tectonostratigraphic units, terrane boundaries and plate tectonic evolution. In: Franke, W., Haak, V., Oncken, 0. and Tanner, D. (eds): Orogenic Processes: quantification and modelling in the Variscan Belt. Special Publications, Geological Society, London 179: 35-61.

Franke, W., 2006. The Variscan orogen in Central Europe: construction and collapse. In: Gee, D.G. \& Stephenson, R.A. (eds): European lithosphere dynamics. Geological Society, London, Memoirs 32: 333-343.

Franks, D., 2007. Fossil-plant treasure trove open for hunters. Earth Heritage 29: 8.

Fraser, A.J. \& Gawthorpe, R.L., 1990. Tectono-stratigraphic development and hydrocarbon habitat of the Carboniferous in northern England. In: Hardman, R.F.P. \& Brooks, J. (ed.): Tectonic Events rsponsible for Britain's 0il and Gas Reserves. Geological Society of London, Special Publication No. 55: 49-86.

Fraser, H.E. \& Cleal, C.J., 2007. The contributions of British women to Carboniferous palaeobotany during the first half of the 20th century. In: Burek, C.V. \& Higgs B. (eds): The role of women in the history of geology. Geological Society of London, Special Publication 281: 51-82.

Fritz, A. \& Boersma, M., 1983a. Fundberichte über Pflanzenfossilien aus Kärnten Beiträge 3 und 4. Carinthia II, Klagenfurt 173/93: 19-41.

Fritz, A. \& Boersma, M., 1983b. Fundberichte über Pflanzenfossilien aus Kärneten 1983 Beitrag 5. Carinthia II, Klagenfurt 173/93: 315-337.

Fulton, I.M., 1987. Genesis of the Warwickshire Thick Coal: a group of longresidence histosols. In: Scott, A.C. (ed.): Coal and coal-bearing strata: recent advances. Geological Society, London, Special Publication 32: 201-218.

Gaitzsch, B., Rößler, R., Schneider, J.W. \& Schretzenmayer, S., 1998. Neue Ergebnisse zur Verbreitung potentieller Muttergesteine im Karbon der variscischen Vorsenke in Nordostdeutschland. Geologisches Jahrbuch A 149: 25-58.

Gastaldo, R.A., 1977. A Middle Pennsylvanian nodule flora from Carterville, Illinois. In: Romans, R.D. (ed.): Geobotany. Plenum Press (New York): 133-155.

Gastaldo, R.A., 1981. Taxonomic considerations for Carboniferous coalified compression equisetalean strobili. American Journal of Botany 68: 1319-1324.

Gastaldo, R.A., 1992. Regenerative growth in fossil horsetails following burial by alluvium. Historical Biology 6: 203-219.

Gastaldo, R.A., DiMichele, W.A. \& Pfefferkorn, H.W., 1996. Out of the Icehouse into the Greenhouse: a Late Paleozoic analog for modern global vegetational change. GSA Today 6: 1-7.

Gayer, R.A., Cole, J.E., Greiling, R.O., Hecht, C. \& Jones, J.A., 1993. Comparative evolution of coal-bearing foreland basins along the Variscan northern margin in Europe. In: Gayer, R.A., Greiling, R.0. \& Vogel, A.K. (eds): Rhenohercynian and Subvariscan fold belts. Vieweg \& Sons (Braunschweig): 47-82.

Gayer, R.A. \& Jones, J.A., 1989. The Variscan Foreland in South Wales. Proceedings of the Ussher Society 7: 177-179.

Gayer, R.A. \& Pešek, J., 1992. Cannibalisation of Coal Measures in the South Wales Coalfield - significance for foreland basin evolution. Proceedings of the Ussher Society 8: 44-49. 
Gayer, R.A. \& Stead, J.T.G., 1971. The Forest of Dean coal and iron-ore fields. In: Bassett, D.A. \& Bassett, M.G. (eds): Geological excursions in South Wales \& the Forest of Dean. Geologists' Association South Wales Group (Cardiff): 21-36.

Geinitz, H.G., 1855. Die Versteinerungen der Steinkohlenformation in Sachsen. W. Engelmann (Leipzig): $61 \mathrm{pp.}$

Germar, E.F., 1844. Die Vesteinerungen des Steinkohlengebirges von Wettin und Löbejün im Saalkreis, Halle. Königlich Preussische Geolgische Landesanstalt (Berlin): $116 \mathrm{pp}$.

Germer, $\boldsymbol{R} .$, 1971. Leitfossilien in der Schichtenfolge des Saarkarbons. Beihefte zur Geologischen Landesaufnahme des Saarlandes 3: 1-124.

Germer, R., Kneuper, G.K. \& Wagner, R.H., 1968. Zur Westfal/Stefan-Grenze und zur Frage der asturischen Faltungsphase im Saarbrücker Hauptsattel. Geologica et Palaeontologica 2: 59-71.

Gibling, M.R. \& Bird, D.J., 1994. Late Carboniferous cyclothems and alluvial paleovalleys in the Sydney Basin, Nova Scotia. Bulletin of the Geological Society of America 106: 105-117.

Gibling, M.R., Saunders, K.I., Tibert, N.E. \& White, J.A., 2004. Sequence sets, high accommodation events, and the Coal Window in the Carboniferous Sydney Coalfield, Atlantic Canada. In: Pashin, J. C. \& Gastaldo, R. A (eds): Sequence stratigraphy, paleoclimate, and tectonics of coal-bearing strata. AAPG Studies in Geology 51: 169-197.

Glennies, K.W., 2005. Regional tectonics in relation to Permo-Carboniferous hydrocarbon potential, Southern North Sea Basin. In: Collinson, J.D., Evans, D.J., Holliday, D.W. \& Jones, N.S. (eds): Carboniferous hydrocarbon resources: the southern North Sea and surrounding areas. Occasional Special Publication of the Yorkshire Geological Society 7: 1-12.

Glover, B.W., Powell, J.H. \& Waters, C.N., 1993. Etruria Formation (Westphalian C) palaeoenvironments and volcanicity on the southern margins of the Pennine Basin, south Staffordshire, England. Journal of the Geological Society 150: 737-750.

González, C.R., 1990. Development of the Late Paleozoic glaciations of the South American Gondwana in western Argentina. Palaeogeography, Palaeoclimatology, Palaeoecology 79: 275-287.

Good, C.W., 1978. Taxonomic characteristics of sphenophyllalean cones. American Journal of Botany 65: 86-97.

Gorder, P.F., 2001. Largest fossil cockroach found: site preserves incredible detail. Ohio State University Research (http://researchnews.osu.edu/ archive/bigroach.htm).

Gradstein, F., Ogg, J. \& Smith, A., 2004. A geological time scale 2004. Cambridge University Press (Cambridge): 589 pp.

Gradziński, R., 1982. Explanatory notes to the lithotectonic molasse profile of the Upper Silesian Basin (Upper Carboniferous - Lower Permian). Veröffentlichungen des Zentralinstituts für Physik der Erde AdW DDR, Potsdam (1982): 225-235.

Grauvogel-Stamm, L., Gall, J.-C., Laveine, J.-P., Brousmiche, C. \& Duringer, P., 1992. Carboniferous of Sarre-Lorraine Coal Basin. $4^{\text {th }}$ International Organization of Palaeobotany Conference, Pre-Congress Excursion. O.F.P. Informations, Numero Special 16A: 1-12.

Greb, S.F., Andrews, W.M., Eble, C.F., DiMichele, W., Cecil, C.B. \& Hower, J.C., 2003. Desmoinesian coal beds of the Eastern Interior and surrounding basins: the largest tropical peat mires in Earth history. In: Chan, M.A. \& Archer, A.W. (eds): Extreme depositional environments: mega end members in geologic time. Geological Society of America, Special Paper 370: 127-150.
Grebe, H., 1972. Die Verbreitung der Mikrosporen im Ruhrkarbon von den Bochumer Schichten bis zu den Dorstener Schichten (Westfal A-C). Palaeontographica, Abteilung B 140: 27-115.

Guion, P.D. \& Fielding, C.R., 1988. Westphalian A and B sedimentation in the Pennines Basin, UK. In: Besly, B. \& Kelling, G. (eds): Sedimentation in a synorogenic basin complex, the Upper Carboniferous of northwest Europe. Blackie (London): 153-177.

Guion, P.D., Fulton, I.M. \& Jones, N.S., 1995. Sedimentary facies of the coalbearing Westphalian A and B north of the Wales-Brabant High. Special Publication of the Geological Society of London 82: 45-78.

Guthörl, P., 1952. Die Leit-Fossilien und Stratigraphie des saar-lothringischen Karbons. Compte rendu $3^{\text {e }}$ Congrès International de Stratigraphie et de Géologie du Carbonifère (Heerlen, 1951) 1: 233-242.

Hallsworth, C.R. \& Chisholm, J.I., 2000. Stratigraphic evolution of provenance characteristics in Westphalian sandstones of the Yorkshire Coalfield. Proceedings of the Yorkshire Geological Society 53: 43-72.

Hallsworth, C.R., Morton, A.C., Claoué-Long, J.C. \& Fanning, C.M., 2000. Carboniferous sand provenance in the Pennine basin, UK: constrains from heavy minerals and detrital zircon age data. Sedimentary Geology 137: 147-185.

Hampson, G.J., 1998. Evidence for relative sea-level falls during deposition of the Upper Carboniferous Millstone Grit, South Wales. Geological Journal 33: 243-266.

Hampson, G.J., Stollhofen, H. \& Flint, S.S., 1999. A sequence stratigraphic model for the Lower Coal Measures (Upper Carboniferous) of the Ruhr District, northwest Germany. Sedimentology 46: 1199-1232.

Handlirsch, A., 1906-08. Die fossilen Insekten und die Phylogenie der Rezenten Formen. Engelmann (Leipzig): $1430 \mathrm{pp}$.

Harms, V.L. \& Leisman, G.A., 1961. The anatomy and morphology of certain cordaites leaves. Journal of Paleontology 35: 1041-1064.

Hartkopf-Fröder, C., 2005. Palynostratigraphie des Oberkarbons. In: Deutsche Stratigraphische Kommission (ed.): Stratigraphie von Deutschland. - Das Oberkarbon (Pennsylvanium) in Deutschland. Courier Forschungsinstitut Senckenberg 254: 133-160.

Hartley, A.J., 1993a. A depositional model for the mid-Westphalian A to late Westphalian B Coal Measures of South Wales. Journal of the Geological Society 150: 1121-1136.

Hartley, A.J., 1993b. Silesian sedimentation in south-west Britain: sedimentary responses to the developing Variscan Orogeny. In: Gayer, R.A., Greiling, R.0. \& Vogel, A.K. (eds): Rhenohercynian and Subvariscan fold belts. Vieweg \& Sons (Braunschweig): 157-196.

Hartley, A.J. \& Warr, L.N., 1990. Upper Carboniferous foreland basin evolution in SW Britain. Proceedings of the Ussher Society 7: 212-216.

Haszeldine, R.S. \& Anderton, R., 1980. A braidplain facies model for the Westphalian B Coal Measures of north-east England. Nature 284: 51-53.

Haubold, H. \& Sarjeant, W.A.S., 1973. Tetrapodenfährten aus den Keele und Enville Groups (Permokarbon, Stefan und Autun) von Shropshire und South Staffordshire, Grossbritannien. Zeitschrift für Geologische Wissenschaften, Berlin 1: 895-933.

Havlena, V., 1964. Geologie uhelných ložisek 2. Nakladateství Československé akademie věd (Praha): 437 pp.

Havlena, V., 1965. Geologie uhelných ložisek 3. Nakladateství Československé akademie věd (Praha): $382 \mathrm{pp}$. 
Havlena, V. \& Pešek, J., 1980. Stratigrafie, paleogeografie a základní strukturní členění limnického permokarbonu Čech a Moravy. Sborník Př́roda 34: 1-144.

Heckel, P.H., 1991. Lost Branch Formation and revision of upper Desmoinesian stratigraphy along Midcontinent outcrop belt. Kansas Geological Survey, Geology Series 4: 1-67.

Heckel, P.H., 2002. Overview of Pennsylvanian cyclothems in midcontinent North America and brief summary of those elsewhere in the world. In: Hill, L.V., Henderson, C.H. \& Bamber, E.W. (eds): Carboniferous and Permian of the world, Proceedings of the XIV ICCP. Canadian Society of Petroleum Geologists Memoir 19: 79-98.

Heckel, P.H. \& Clayton, G., 2006. The Carboniferous System. Use of the new official names for subsystems, series and stages. Geologica Acta 3: 403-407.

Hess, J.C., Backfisch, S. \& Lippolt, H.J., 1983. Konkordantes Sanidin- und diskordante Biotit-alter eines Karbontuffs der Baden-Badener Senke, Nordschwarzwald. Neues Jahrbuch für Geologie und Paläontologie, Monatshefte: 277-292.

Hess, J.C., Lippolt, H.J., Holub, V.M. \& Pešek, J., 1985. Isotopic ages of two Westphalian $C$ tuffs - a contribution to the Upper Carboniferous timescale. Terra Cognita 5: 236-237.

Hollmann, G., 1997. Incremental 2D reconstruction of the Variscan foreland thrust belt (eastern Ardenne, Belgium). Aardkundige Mededelingen 8: 111-114.

Hollmann, G. \& Von Wintereld, C., 1999. Laterale Strukturvariationen eines Vorlandüberschiebungsgürtels. Zeitschrift der Deutschen Geologischen Gesellschaft 150: 431-450.

Holub, V., Jaroš, J., Malý, L., Matínek, K., Pešek, J., Prouza, V., Spudil, J. \& Tásler, R., 2001. Geologie a ložiska svrchnopaleozoických limnických pánví České republiky. Český geologický ústav (Praha): 243 pp.

Horton, D.E. \& Poulsen, C.J., 2009. Paradox of late Paleozoic glacioeustasy. Geology 37: 715-718.

Hoskins, J.H. \& Cross, A.T., 1943. Monograph of the Paleozoic cone genus Bowmanites (Sphenophyllales). American Midland Naturalist 30: 47-148.

Hoth, K., (in press). Die Grobklastit-Horizonte im Zwickauer Oberkarbon. Schriftenreihe Bergbau in Sachsen 15.

Hoth, K. \& Wolf, P., 2007. Untersuchungen zum Ressourcenpotential der ostdeutschen Steinkohlenvorkommen. Schriftenreihe für Geowissenschaften 16: 187-193.

Iannuzzi, R. \& Pfefferkorn, H.W., 2002. A pre-glacial, warm-temperate floral belt in Gondwana (late Visean, Early Carboniferous). Palaios 17: 571-590.

Izart, A., Palain, C., Malartre, F., Fleck, S. \& Michels, R., 2005. Paleoenvironments, paleoclimates and sequences of Westphalian deposits of Lorraine coal basin (Upper Carboniferous, NE France). Bulletin de la Société Géologique de France 176: 301-315.

Jachowicz, A., 1972. Charakterystyka mikroflorystyczna i stratygrafia karbonu produktywnego Górnośląskiego Zagłębia Węglowego. Prace Instytutu Geologicznego 61: 185-277.

Jachowicz, A. \& Dybova-Jachowicz, S., 1983. Application of palynology to geological research in Carboniferous coal basins of Poland. In: Bojkowski, K. \& Porzycki, J. (eds): Geological problems of coal basins of Poland. Geological Institute (Warsaw): 165-185.

Jarzembowski, E.A., 2001a. Insecta (insects). In: Encyclopaedia of Life Sciences. Wiley (Chichester): 1-7.
Jarzembowski, E.A., 2001b. Review of early insects and palaeocommunities. In: Deuve, T. (ed.): Origin of the Hexapoda. Annales de la Société entomologique de France, N. S. 37: 11-19.

Jarzembowski, E.A., 2003. Palaeoentomology: towards the big picture. In: Krzemińska, E. \& Krzemiński, W. (eds): Proceedings of the 2nd Congress on palaeoentomology, 2001. Acta Zoologica Cracoviensia 46 (Supplement): 25-36.

Jarzembowski, E.A., 2004. Atlas of animals from the late Westphalian of Writhlington, United Kingdom. Geologica Balcanica 34: 47-50.

Jarzembowski, E.A., 2005a. Insects. In: Selley, R. C., Cocks, L. R. M., \& Plimer, I. R. (eds): Encyclopaedia of geology 2. Elsevier (0xford): 295-300.

Jarzembowski, E.A., 2005b. Colour and behaviour in Late Carboniferous terrestrial arthropods. Zeitschrift der Deutschen Gessellschaft für Geowissenschaften 156: 381-386.

Jarzembowski, E.A., 2007. IGCP 469 - Late Variscan terrestrial biotas and palaeoenvironments. African Invertebrates 48: 248.

Jarzembowski, E.A., 2008. The oldest insect from Romania: a new Carboniferous blattodean. Studia Geologica Polonica 129: 43-50.

Jarzembowski, E.A. \& Schneider, J.W., 2007. The stratigraphical potential of blattodean insects from the late Carboniferous of southern Britain. Geological Magazine 144: 449-456.

Jones, D.G., 1958. A note on new Namurian plant localities at the head of the Neath Valley, South Wales. Geological Magazine 95: 77-81.

Jones, J.A., 1972. Qartzarenite and litharenite facies in the fluvial foreland deposits of the Trenchard Group (Westphalian) Forest of Dean. Sedimentary Geology 8: 177-198.

Jones, J.A., 1989. The influence of contemporaneous tectonic activity on Westphalian sedimentation in the South Wales Coalfield. Occasional Publications of the Yorkshire Geological Society 6: 243-253.

Jones, J.A., 1991. A mountain front model for the Variscan deformation of the South Wales coalfield. Journal of the Geological Society 148: 881-891.

Jongmans, W.J., 1911. Anleitung zur Bestimmung der Karbonpflanzen WestEuropas mit besonderer Berücksichtigung der in den Niederlanden und den benachbarten Länderen gefundenen oder noch $\mathrm{zu}$ erwartenden Arten. I Band. Thallophytae, Equisetales, Sphenophyllales. Mededelingen van de Rijksopsporing van Delfstoffen 3: 1-482.

Jongmans, W.J. \& Kukuk, P., 1913. Die Calamariacean des RheinischWestfälischen Kohlnenbeckens. Mededelingen van Rijks Herbarium, Leiden 20: 1-89.

Josten, K.-H., 1991. Die Steinkohlen-Floren Nordwestdeutschlands. Fortschritte in der Geologie von Rheinland und Westfalen 36: $434 \mathrm{pp}$.

Josten, K.-H., 1995. Stratigraphie des Oberkarbons: Untersuchung der Makrofloren. DGMK-Forschungsbericht 459: 1-239.

Josten, K.-H., 2005. Florenstratigraphie des Oberkarbons in Nordwestdeutschland. In: Deutsche Stratigraphische Kommission (ed.): Stratigraphie von Deutschland - Das Oberkarbon (Pennsylvanium) in Deutschland. Courier Forschungsinstitut Senckenberg 254: 119-132.

Josten, K.-H. \& Van Amerom, H.W.J., 1999. Die Pflanzenfossilien im Westfal D, Stefan und Rotliegend Norddeutschlands. Fortschritte in der Geologie von Rheinland und Westfalen 39: 1-168.

Josten, K-H. \& Laveine, J-P., 1984. Paläobotanisch-stratigraphische Untersuchungen im Westphalian C-D von Nordfrankreich und Nordwestdeutschland. Fortschritte in der Geologie von Rheinland und Westfalen 32: 89-117. 
Kalibová-Kaiserová, M., 1956. Zpráva o palynologickém výzkumu českých permokarbonských pánví. Zprávy o Geologických Výzkumoch (ÚÚG) 1955: 82-83.

Kędzior, A., Gradziński, R., Doktor, M. \& Gmur, D., 2007. Sedimentary history of a Mississippian to Pennsylvanian coal-bearing succession - an example from the Upper Silesia Coal Basin, Poland. Geological Magazine 144: 487-496.

Kellaway, G.A., 1969. The Upper Coal Measures of south-west England compared with those of South Wales and the southern Midlands. Compte rendu, Sixiéme Congres International de Stratigraphie et de Géologie du Carbonifére (Sheffield, 1967) 2: 1039-1056.

Kellaway, G.A. \& Welch, F.B.A., 1993. Geology of the Bristol district. Memoirs of the British Geological Survey, xii +199 pp.

Kelling, G., 1974. Upper Carboniferous sedimentation in south Wales. In: Owen, T.R. (ed.): The Upper Palaeozoic and post-Palaeozoic rocks of Wales. University of Wales Press (Cardiff): 185-244.

Kelling, G., 1988. Silesian sedimentation and tectonics in the South Wales Basin: a brief review. In: Besly, B. \& Kelling, G. (eds): Sedimentation in a synorogenic basin complex, the Upper Carboniferous of northwest Europe. Blackie (London): 38-42.

Kelling, G. \& Collinson, J.D., 1992. Silesian. In: Duff, P.M.D. \& Smith, A.J. (eds): Geology of England and Wales. Geological Society (London): 239-273.

Kerp, J.H.F., 1996. Post-Varsican late Palaeozoic Northern Hemisphere gymnosperms: the onset to the Mesozoic. Review of Palaeobotany and Palynology 90: 263-285.

Kidston, $\boldsymbol{R} ., 1901$. Carboniferous lycopods and sphenophylls. Transactions of the Natural History Society of Glasgow, New Series 6: 25-140.

Kidston, R., 1924. Fossil plants of the Carboniferous rocks of Great Britain. Part 5. Memoirs of the Geological Survey of Great Britain, Palaeontology 2: 377-522.

Kidston, R., Cantrill, T.C. \& Dixon, E.E.L., 1917. The Forest of Wyre and the Titterstone Clee Hill Coal Fields. Transactions of the Royal Society of Edinburgh 51: 999-1084.

Kidston, R. \& Jongmans, W.J., 1917. Flora of the Carboniferous of the Netherlands and adjacent regions. Vol. I, Calamites of western Europe. Mededelingen van de Rijksopsporing van Delfstoffen 7: 1-207 (Atlas published in 1915).

Knauff, W., Köwing, K. \& Rabitz, A., 1971. Der erste Nachweis von Horizonten mit Foraminiferen im Westfal D von Nordwestdeutschland. Fortschritte in der Geologie von Rheinland und Westfalen 18: 257-262.

Kneuper, G., 1967. Neue geologische Karte vom saarländischen Steinkohlengebirge. Schacht und Heim 9-10 (Supplement): 1-4.

Kneuper, G., 1971. The Saar-Nahe District. In: Bachmans, M. and other 28 co-authors: The Carboniferous deposits in the Federal Republic of Germany. A Review. Fortschritte in der Geologie von Rheinland und Westfalen 19: 146165.

Koenig, C., 1825. Icones fossilium sectiles. London: 44 pp.

Kombrink, H., Leever, K.A., Van Wees, J.D., Van Bergen, F., David, P. \& Wong, T.E., 2008. Late Carboniferous foreland basin formation and Early Carboniferous stretching in Northwestern Europe - Inferences from quantitative subsidence analyses in the Netherlands. Basin Research 20: 377-395.

Konstantinova, V., 1980. Morfologia i razpredelenie na ekzinitovata sastavka vav vaglishtata ot Dobrudzhanskia basein. Izvestiya na Geologicheskiya Institut 12: $45-54$.
Konstantinova, V. \& Nikolov, Z., 1974. Petrology of Upper Carboniferous coal in Bulgaria's Dobrudja Basin. Compte Rendu $7^{\mathrm{e}}$ Congrès International de Stratigraphie et du Géologie du Carbonifère (Krefeld, 1971) 3: 317-331.

Korsch, R.J. \& Schäfer, A., 1995. The Permo-Carboniferous Saar-Nahe Basin, south-west Germany and north-east France: basin formation and deformation in a strike-slip regime. International Journal of Earth Sciences 84: 293-318.

Kotas, A., 1994. Geological background. In: Kotas, A. (ed.): Coal-bed methane potential of the Upper Silesian Coal Basin, Poland. Prace Państwowego Instytutu Geologicznego (Warszawa) 142: 6-18.

Kotas, A. \& Malczyk, W., 1972. The Paralic Series of the Lower Namurian stage of the Upper Silesian Coal Basin. Prace Instytutu Geologicznego 61, 329-425. (In Polish, with English summary).

Kotasowa, A., 1979. Fitostratygrafia najwyzszego odcinka profilu karbonu produktywnego Grnoslaskiego Zaglebia Weglowego. Kwartalnik Geologiczny 23: $525-532$

Kotková, J. \& Parish, R., 2000. Evidence for high exhumation rate in central European Variscides: U-Pb ages of granulite metamorphism of clasts deposited in Upper Viséan conglomerates. Geolines 10: 41-42.

Köwing, K. \& Rabitz, A., 2005. 0snabrücker Karbon. In: Deutsche Stratigraphische Kommission (Ed.): Stratigraphie von Deutschland. - Das Oberkarbon (Pennsylvanium) in Deutschland. Courier Forschungsinstitut Senckenberg 254: 255-270

Krings, M., Kerp, H., Taylor, E.L. \& Taylor, T.N., 2001. Reconstruction of Pseudomariopteris busquetii, a vine-like Late Carboniferous-Early Permian pteridosperm. American Journal of Botany 88: 767-776.

Kullmann, J., Wagner, R.H. \& Winkler Prins, C.F., 2007. Significance for international correlation of the Perapertú Formation in northern Palencia, Cantabrian Mountains. Tectonic/stratigraphic context and descriptions of Mississippian and upper Bashkirian goniatites. Revista Espñola de Paleontología 22: 127-145

Labandeira, C.C., 2002. Paleobiology of predators, parasitoids, and parasites: death and accommodation in the fossil record of continental invertebrates. Paleontological Society Papers 8: 211-249.

Labandeira, C.C., 2006. The four phases of plant-arthropod associations in deep time. Geologica Acta 4: 409-438.

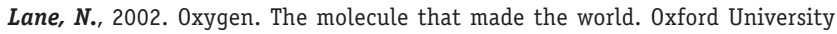
Press: $388 \mathrm{pp}$.

Laveine, J.-P., 1967. Contribution a l'étude de la flore du terrain houiller. Les Neuroptéridées du Nord de la France. Études Géologiques pour l'Atlas Topographie Souterraine 1(5): 1-344.

Laveine, J.-P., 1977. Report on the Westphalian D. In: Holub, V.M. \& Wagner, R.H. (eds): Symposium on Carboniferous Stratigraphy. Geological Survey (Prague): 71-83.

Laveine, J.-P., 1986. The size of the frond in the genus Alethopteris Sternberg (Pteridospermopsida, Carboniferous). Geobios 19: 49-56.

Laveine, J-P., 1987. La flore du basin houiller du Nord de la France. Biostratigraphie et méthodologie. Annales de la Société géologique du Nord 106: 87-93.

Laveine, J.-P., 1989. Guide paléobotanique dans le terrain houiller Sarro-Lorrain. Houillères du Bassin de Lorraine (Merlebach): $154 \mathrm{pp}$.

Laveine, J.-P., Lemoigne, Y., \& Zhang Shanzhen, 1993. General characteristics and paleobiogeography of the Parispermaceae (genera Paripteris Gothan and Linopteris Presl), pteridosperms from the Carboniferous. Palaeontographica, Abteilung B 230: 81-139. 
Ledran, C., 1966. Contributions à l'étude des feuilles de Cordaitales. Théses présentées à la Faculté des Sciences de l'Académie de Reims, Série 1.

Leeder, M.R. \& Harman, M., 1990. Carboniferous geology of the Southern North Sea Basin and controls on hydrocarbon prospectivity. In: Hardman, R.F.P. and Brooks, J. (ed.): Tectonic Events rsponsible for Britain's 0il and Gas Reserves. Geological Society of London, Special Publication No. 55: 87-105.

Libertín, M. \& Bek, J., 2008. Review of monolete-producing CarboniferousPermian sphenophylls. Terra Nostra 2008/2: 168.

Lippolt, H.J., Hess, J.C. \& Burger, K., 1984. Isotopische Alter von pyroklastischen Sanidinen aus Kaolin-Kohlentonstein als Korrelationsmarker für das mitteleuropäische Oberkarbon. Fortschritte in der Geologie von Rheinland und Westfalen 32: 119-150.

Lojka, R., Drábková, J., Zajíc, J., Sýkorová, I., Francủ, J., Bláhová, A. \& Grygar, T., 2009. Climate variability in the Stephanian B based on environmental record of the Mšec Lake deposits (Kladno-Rakovník Basin, Czech Republic). Palaeogeography, Palaeoclimatology, Palaeoecology 280: 78-93.

Lucas, S.G., Schneider, J.W. \& Cassinis, G., 2006. Non-marine Permian biostratigraphy and biochronology: an introduction. In: Lucas, S.G., Cassinis, G. and Schneider, J.W. (eds): Non-marine Permian biostratigraphy and biochronology. Geological Society, London, Special Publication 265, 1-14.

Luckert, J. \& Bautsch, H.-J., (in press). Kohlentonsteine. Schriftenreihe Bergbau in Sachsen 15.

Lund, J.J., 2001. Vittatina in Westphalian D of the North Sea? In: 1st Meeting of the Commission Internationale de Microflore du Paléozoïque Spores and Pollen Subcommission, National University of Ireland, Cork, Ireland, $2^{\text {nd }}$ to $7^{\text {th }}$ September 2001, Programme and Abstracts: 24.

Lyons, P.C. \& Darrah, W.C., 1989. Earliest conifers of North America: upland and/or paleoclimatic indicators? Palaios 4: 480-486.

Lyons, P.C., Spears, D.A, Outerbridge, W.F., Congdon, R.D. \& Evans, H.T., 1994. Euramerican tonsteins: overview, magmatic origin, and depositional-tectonic implications. Palaeogeography, Palaeoclimatology, Palaeoecology 106: 113-134.

Marchioni, D., Gibling, M.R. \& Kalkreuth, W., 1996. Petrography and depositional environment of coal seams in the Carboniferous Morien Group, Sydney Coalfield, Nova Scotia. Canadian Journal of Earth Sciences 33: 863-874.

Marshall, A.E. \& Smith, A.H.V., 1964. Assemblages of miospores from some Upper Carboniferous coals and their associated sediments in the Yorkshire Coalfield. Palaeontology 7: 656-673.

Martin, C.A.L., Doubleday, P.A. \& Stewart, S.A., 2002. Upper Carboniferous and Lower Permian tectonostratigraphy on the southern margin of the Central North Sea. Journal of the Geological Society, London 159: 731-749.

Matl, K., 1966. Problem identyfikacji warstw zabrskich (siodłowych s.s.) w niecce chwałowickiej karbonu górnośląskiego. Przegląd Geologiczny 6: 265-268.

Matysová, P., Leichman, J., Grygar, T. \& Rössler, R., 2008. Cathodoluminiscence of silicified trunks from the Permo-Carboniferous basis in eastern Bohemia, Czech Republic. European Journal of Mineralogy 20: 217-231.

Maynard, J., Hofmann, W., Dunay, R.E., Bentham, P.N., Dean, K.P. \& Watson, I., 1997. The Carboniferous of western Europe: the development of a petroleum system. Petroleum Geoscience 3: 97-115.

McLean, D., Owens, B. \& Bodman, D., 2004. Palynostratigraphy of the Upper Carboniferous Langsettian-Duckmantian Stage boundary in Britain. In: Beaudin, A.B. \& Head, M.J. (eds): Palynology and micropalaeontology of boundaries. Geological Society of London, Special Publication No. 230: 123-135.
McLean, D., Owens, B. \& Neves, $R$., 2005. Carboniferous miospore biostratigraphy of the North Sea. In: Collinson, J.D., Evans, D.J., Holliday, D.W. \& Jones, N.S. (eds): Carboniferous hydrocarbon resources: the southern North Sea and surrounding areas. Occasional Special Publication of the Yorkshire Geological Society 7: 13-24.

Mencl, V., Matysová, P. \& Sakala, J., 2009. Silicified woods from the Czech part of the Intra Sudetic Basin (Late Pennsylvanian, Bohemian Massif, Czech Republic): systematics, silicification and palaeoenvironment. Neues Jahrbuch für Geologie und Paläontologie, Abhandlungen 252/3: 269-288.

Menning, M., Weyer, D., Wendt, I., Drozdzewski, G. \& Hambach, U., 2005. Eine Numerische Zeitskala für das Pennsylvanium in Mitteleuropa. In: Deutsche Stratigraphische Kommission (ed.): Stratigraphie von Deutschland - Das Oberkarbon (Pennsylvanium) in Deutschland. Courier Forschungsinstitut Senckenberg 254: 181-189

Meyen, S.V., 1970. Epidermisuntersuchungen an permischen Landpflanzen des Angaragebietes. Paläontologische Abhandlungen B 3: 523-552.

Meyen, S.V., 1982. The Carboniferous and Permian floras of Angaraland (a synthesis). Biological Memoirs 7: 1-110.

Migier, T., 1980. The Carboniferous phytostratigraphy of the Lublin coal Basin. Biulletyn Instytutu Geologicznego 328: 61-73.

Mitchell, A.A., 2003. Towards a global fossil insect database. In: Krzemińska, E. \& Krzemiński, W. (eds): Proceedings of the 2nd Congress on palaeoentomology, 2001. Acta zoologica cracoviensia 46 (Supplement): 51-57.

Mitchell, A.A., 2007. EDNA The world-wide fossil insect catalogue. African Invertebrates 48: 249.

Möhring, G. \& Schäfer, A., 1990. Caliche im Stefan des Saar-Nahe-Beckens. Mainzer geowissenschaftlicher Mitteilungen 19: 63-80.

Moore, L.R. \& Blundell, C.R.K., 1952. Some effects of the Malvernian phase of earthmovements in the South Wales Coalfield, a comparison with other coalfields in south Britain. Compte rendu 3e Congrès de Stratigraphie et de Géologie du Carbonifère (Heerlen, 1951) 2: 463-473.

Musiał, E. \& Tabor, M., 1988. Stratygrafia karbonu na podstawie makrofauny. In: Z. Dembowski, J. Porzycki (eds), Karbon Lubelskiego Zagłębia Węglowego. Prace Instytutu Geologicznego 122: 88-122.

Narkiewicz, M., Jarosiński, M., Krzywiec, P. \& Waksmundzka, M. I., 2007. Regionalne uwarunkowania rozwoju i inwersji basenu lubelskiego w dewonie i karbonie. (Regional controls on the Lublin Basin development and inversion in the Devonian and Carboniferous). Biuletyn Państwowego Instytutu Geologicznego 422: 19-34.

Narkiewicz, M., Poprawa, P., Lipiec, M., Matyja, H. \& Miłaczewski, L., 1998. Subsidence development and basin origin. Prace Państwowego Instytutu Geologicznego 165: 31-46. (In Polish).

Nascimento, F.E.M. \& Laurance, W.F., 2002. Total aboveground biomass in central Amazonian rainforests: a landscape-scale study. Forest Ecology Management 168: 311-321.

Nel, A., Nel, P., Petrulevičius, J.F., Perrichot, V., Prokop, J. \& Azar, D., in press. The Wagner Parsimony using Morphological Characters: a new method for palaeosynecological studies. Annales de la Société Entomologique de France.

Němejc, $F$., 1933. Floristicko-stratigrafická studie o poměrech v uhelných revírech u Žacléře, Svatoňovic a u Žd'árků (blíže Hronova). Věstník Československé Společnosti Nauk, Třída math.-přírodověd 5: 1-34.

Nĕmejc, F., 1940. The pecopterides of the coal districts of Bohemia. Sborník Národního Musea v Praze 2 B: 1-28. 
Němejc, F., 1953a. Úvod do floristické stratigrafie kamenouhelných oblastí v ČSR. Československé Akademie Věd (Prague): 173 pp.

Němejc, F., 1953b. Taxonomical studies on the fructifications of the Calamitaceae collected in the coal districts of Central Bohemia. Sborník Národního Musea v Praze 9 B: 3-62.

Němejc, F., 1958. Biostratigrafické studie v karbonu ceského krídla vnitrosudetské páanve. Rozpravy Československé Akademie Věd 68(6): 1-67.

Novik, E.O., 1952. Kamennougol'naya flora evropeiskoi chasti SSSR. Akademii Nauk SSSR, Moscow, Paleontologiya SSSR, Novaya Seriya 1: 468 pp.

Novik, E.O., 1954. Kamennougol'naya flora vostochnoi chasti Donetskogo basseina. Akademii Nauk Ukrainskoi SSR, Kiev, Trudy Instituta Geologicheskikh Nauk, Seriya Stratigrafii i Paleontologii 7: 138 pp.

Okajima, R., 2008. The controlling factors limiting maximum body size of insects. Lethaia 41: 423-430.

Opluštil, S., 2005. Evolution of the Middle Westphalian river valley drainage system in central Bohemia (Czech Republic) and its palaeogeographic implication. Palaeogeography, Palaeoclimatology, Palaeoecology 222: 223-258.

Opluštil, S. \& Cleal, C.J., 2007. A comparative analysis of some Late Carboniferous basins of Variscan Europe. Geological Magazine 144: 417-448.

Opluštil, S. \& Pešek, J., 1998. Stratigraphy, palaeoclimatology and palaeogeography of the Late Palaeozoic continental deposits in the Czech Republic. Geodiversitas 20: 597-619.

Opluštil, S., Pšenička, J., Libertín, M., Bashforth, A. \& Šimůnek, Z., 2009. A Middle Pennsylvanian (Bolsovian) peat-forming forest preserved in situ in volcanic ash of the Whetstone Horizon in the Radnice Basin, Czech Republic. Review of Palaeobotany and Palynology 155: 234-274.

Opluštil, S., Pšenička, J., Libertín, M. \& Šimůnek, Z., 2007. Vegetation patterns of Westphalian and lower Stephanian mire assemblages preserved in tuff beds of the continental basins of Czech Republic. Review of Palaeobotany and Palynology 143: 107-154.

Opluštil, S., Sýkorová, I. \& Bek, J., 1999. Sedimentology, coal petrography and palynology of the Radnice Member in the S-E part of the Kladno-Rakovník Basin, Central Bohemia. Acta Universitatis Carolinae - Geologica 43: 599-623.

Pallardy, S.G. \& Kozlowski, T.T., 2008. Physiology of wody plants. 3rd edition. Elsevier (Amsterdam): $454 \mathrm{pp}$.

Pascucci, V., Gibling, M.R. \& Williamson, M.A., 2000. Late Paleozoic to Cenozoic history of the offshore Sydney Basin, Atlantic Canada. Canadian Journal of Earth Sciences 37: 1143-1165.

Pearce, T.J., McLean, D., Wray, D., Wright, D.K., Jeans, C.J. \& Mearns, E.W., 2005. Stratigraphy of the Upper Carboniferous Schooner Formation, southern North Sea: chemostratigraphy, mineralogy, palynology and Sm-Nd isotope analysis. In: Collinson, J.D., Evans, D.J., Holliday, D.W. \& Jones, N.S. (eds): Carboniferous hydrocarbon resources: the southern North Sea and surrounding areas. Occasional Special Publication of the Yorkshire Geological Society 7: 165-182.

Peppers, R.A., 1985. Comparison of miospore assemblages in the Pennsylvanian System of the Illinois Basin with those in the Upper Carboniferous of western Europe. Proceedings of the $9^{e}$ International Carboniferous Congress (Washington \& Urbana, 1979) 2: 483-502.

Peppers, R.A., 1996. Palynological correlation of major Pennsylvanian (Middle and Upper Carboniferous) chronostratigraphic boundaries in the Illinois and other coal basins. Geological Society of America Memoir 188: 1-111.
Peppers, R.A., 1997. Palynology of the Lost Branch Formation of Kansas - new insights on the major floral transition at the Middle-Upper Pennsylvanian boundary. Review of Palaeobotany and Palynology 98: 223-246.

Pešek, J., 1994. Carboniferous of Central and Western Bohemia (Czech Republic). Czech Geological Survey (Prague): 61 pp.

Pešek, J., 2004. Late Palaeozoic limnic basis and coal deposits of the Czech Republic. Folia Musei Rerum Naturalium Bohemiae 0ccidentalis, Geologica 1: 1-188.

Pešek, J., Jaroš, J., Malý, L., Martínek, K., Prouza, V., Spudil, J. \& Tásler, R., 2001. Geologie a ložiska svrchnopaleozoických limnických pánví České republiky. Český geologický ústav (Prague): 243 pp.

Pešek, J., Opluštil, S., Kumpera, O., Holub, V. \& Skoček, V., 1998. Paleogeographic Atlas, Late Paleozoic and Triassic Formations, Czech Republic. Czech Geological Survey (Prague): 53 pp.

Pešek, J. \& Urban, M., 1990. The tectonic evolution of the Plzeň basin (Upper Carboniferous, West Bohemia): a review and reinterpretation. Folia Musei Rerum Naturalium Bohemiae 0ccidentalis, Geologica 32: 1-56.

Petrunkevitch, A., 1953. Paleozoic and Mesozoic Arachnida of Europe. Memoirs of the Geological Society of America 53: 1-128.

Peyser, C.E. \& Poulsen, C.J., 2008. Controls on Permo-Carboniferous precipitation over tropical Pangaea: a GCM sensitivity study. Palaeogeography, Palaeoclimatology, Palaeoecology 268: 181-192.

Pfefferkorn, H.W., Archer, A.W. \& Zodrow, E.L., 2001. Modern tropical analogs for Carboniferous standing forests: comparison of extinct Mesocalamites with extant Montrichardia. Historical Biology 15: 235-250.

Pfefferkorn, H.W., Gastaldo, R.A., DiMichele, W.A. \& Phillips, T.L., 2008. Pennsylvanian tropical floras from the United States as a record of changing climate. In: Fielding, C.R., Frank, T.D. \& Isbell, J.L. (eds): Resolving the Late Paleozoic ice age in time and space. Geological Society of America Special Paper 441: 305-316.

Pfefferkorn, H.W. \& Thomson, M.C., 1982. Changes in dominance patterns in upper Carboniferous plant-fossil assemblages. Geology 10: 641-644.

Pharaoh, T.C., Winchester, J.A., Verniers, J., Lassen, A. \& Seghedi, A., 2006. The western accretionary margin of the East European Craton: an overview. In: Gee, D.G. \& Stephenson, R.A. (eds): European Lithosphere Dynamics. Geological Society, London, Memoirs, 32, 291-311.

Phillips, T.L., 1981. Stratigraphic occurrences and vegetational patterns of Pennsylvanian pteridosperms in Euramerican coal swamps. Review of Palaeobotany and Palynology 32: 5-26.

Phillips, T.L. \& Cecil, C.B., 1985. Paleoclimatic controls on coal resources of the Pennsylvanian System of North America - introduction and overview of contributions. International Journal of Coal Geology 5: 1-6.

Phillips, T.L. \& DiMichele, W.A., 1981. Paleoecology of Middle Pennsylvanian age coal swamps in southern Illiniois/Herrin Coal Member at Sahara Mine No. 6. In: Niklas, K.J. (ed.): Paleobotany, paleoecology and evolution. Praeger Press (New York): 231-285.

Phillips, T.L. \& DiMichele, W.A., 1992. Comparative ecology and life-history biology of arborescent lycopsids in Late Carboniferous swamps of North America. Annals of the Missouri Botanical Garden 79: 560-588.

Phillips, T.L., Peppers, R.A. \& DiMichele, W.A., 1985. Stratigraphic and interregional changes in Pennsylvanian coal-swamp vegetation: environmental inferences. International Journal of Coal Geology 5: 43-109. 
Pietzsch, K., 1942. Die sächsischen Vorkommen. In: Der Deutsche Steinkohlenbergbau, 1: 243-251

Plotnick, R.E., Kenig, F., Scott, A. \& Glasspool, I., 2008. Stop 3: exceptionally well-preserved paleokarst and Pennsylvanian cave-fills. In: Curry, B. (ed.): Deglacial history and paleoenvironments of northern Illinois. Illinois State Geological Survey. Open File Report 2008-01: 79-87.

Poole, E.G., 1969. The stratigraphy of the Geological Survey Apley Barn Borehole, Witney, Oxfordshire. Bulletin of the Geological Survey of Great Britain 29: 1-77.

Porzycki J., 1979. Litostratygrafia osadów karbonu Lubelskiego Zagłębia Węglowego. In: T. Migier (ed.): Stratygrafia Węglonośnej Formacji Karbońskiej w Polsce, II Sympozjum Sosnowiec, 4-5 maja 1977: 19-27.

Potonié, R. \& Kremp, G., 1954. Die Gattungen der Palaözoischen Sporae dispersae und ihre Stratigraphie. Geologische Jahrbuch 69: 111-193.

Potonié, R. \& Kremp, G., 1955. Die Sporae dispersae des Ruhrkarbons ihre Morphographie und Stratigraphie mit Ausblicken auf Arten anderer Gebiete und Zeitabschnitte. Teil I. Palaeontographica, Abteilung B 98: 1-136.

Poulsen, C.J., Pollard, D. Montañez, I. \& Rowley, D., 2007. Late Paleozoic tropical climate response to Gondwanan glaciations. Geology 35: 771-774.

Powell, J.H., Chisholm, J.I., Bridge, D.M., Rees, J.G., Glover, B.W. \& Besly, B.M., 2000. Stratigraphical framework for Westphalian to Early Permian red-bed successions of the Pennine Basin. Geological Survey (Keyworth) (Research Report No. R/00/01): 28 pp.

Proctor, C.J., 1994. Carboniferous fossil plant assemblages and palaeoecology at the Writhlington Geological Nature Reserve. In: Jarzembowski, E.A. (ed.): Writhlington Special Issue. Proceedings of the Geologists' Association 105: 277-286.

Prokop, J. \& Nel, A., 2007. An enigmatic Palaeozoic stem-group: Paoliida, designation of new taxa from the Upper Carboniferous of the Czech Republic (Insecta: Paoliidae, Katerinkidae fam. nov.). African Invertebrates 48, 77-86.

Prokop, J. \& Ren, D., 2007. New significant fossil insects from the Upper Carboniferous of Ningxia in northern China (Palaeodictyoptera, Archaeorthoptera). European Journal of Entomology 104: 267-275.

Prokop, J., Nel, A. \& Hoch, I., 2005. Discovery of the oldest known Pterygota in the Lower Carboniferous of the Upper Silesian Basin in the Czech Republic (Insecta: Archaeorthoptera). Geobios 38: 383-387.

Prokop, J., Smith, R., Jarzembowski, E. A. \& Nel, A., 2006. New homoiopterids from the Late Carboniferous of England (Insecta: Palaeodictyoptera). Comptes Rendus Palevol 5: 867-873.

Prüfert, J., 1994. Erläuterungen zur Geologischen Karte von NordrheinWestfalen 1:25 000; Blatt 5002 Geilenkirchen (2. Edition). Krefeld.

Pšenička, J., Bek J., Cleal C.J., Wittry, J. \& Zodrow, E.L., 2009. Description of synangia and spores of the holotype of the Carboniferous fern Lobatopteris miltoni, with taxonomic comments. Review of Palaeobotany and Palynology 155: 133-144.

Pšenička, J. Zodrow, E.L., Mastalerz, M., \& Bek, J., 2005. Functional groups of fossil marattialeans,: chemotaxonomic implications for Pennsylvanian tree ferns and pteridophylls. International Journal of Coal Geology 61: 259-280.

Purkyñová, E., 1962. Flóra produktivního karbonu ostravsko-karvinského revíru. Pracovní metody geologické služby 3: 1-116.

Purkyñová, E., 1986. Floristická zonálnost žacléřského souvrství v důlním poli Dolu Šverma u Žacléře (vnitrosudetská pánev). Časopis Slezského Muzea Opava (A) 35: 57-63.
Quirk, D.G., 1993. Interpreting the Upper Carboniferous of the Dutch Cleaver Bank High. In: Parker, J.R. (ed.): Petroleum Geology of Northwest Europe: Proceedings of the 4th Conference. Geological Society (London): 687-706.

Quirk, D.G., 1997. Sequence stratigraphy of the Westphalian in the northern part of the Southern North Sea. In: Ziegler, K., Turner, P. \& Daines, S.R. (eds): Petroleum Geology of the Southern North Sea: Future Potential. Geological Society of London, Special Publication No. 123: 153-168.

Rabitz, G., 1966. Cordaiten aus dem flözführenden Oberkarbon des Ruhrgebiets. Fortschritte in der Geologie von Rheinland und Westfalen 13: 303-316.

Ramsbottom, W.H.C., Calver, M.A., Eagar, R.M.C., Hodson, F., Holliday, D.W., Stubblefield, C.J. \& Wilson, R.B., 1978. A correlation of Silesian rocks in the British Isles. Geological Society (London) (Special Report No.10): 1-82.

Raoult, J. F. \& Meilliez, F., 1987. The Variscan Front and the Midi Fault between the Channel and the Meuse River. Journal of Structural Geology 9: 473-479.

Read, C.B. \& Mamay, S.H., 1964. Upper Paleozoic floral zones and floral provinces of the United States. Professional Papers of the U. S. Geological Survey 454-K: 1-35.

Remy. W., 1955. Untersuchungen von kohlig erhaltenen fertilen und strilen Sphenophyllen und Formen unsicherer systematischer Stellung. Abhandlungen der Deutschen Akademie der Wissenschaften zu Berlin, Klasse für Chemie, Geologie und Biologie 1955 1: 5-40.

Remy. W. \& Remy, R., 1962. Sphenophyllum majus Bronn sp., Sphenophyllum saarensis n. sp. und Sphenophyllum orbicularis n. sp. aus dem Karbon des Saargebietes. Monatsberichte der Deutschen Akademie der Wissenschaften zu Berlin 1962 4: 235-246.

Ren, D., Nel, A. \& Prokop, J., 2008. New early griffenfly, Sinomeganeura huangheensis from the Late Carboniferous of northern China (Meganisoptera: Meganeuridae). Insect Systematics \& Evolution 38: 223-229.

Rippon, J.H., 1996. Sand body orientation, palaeoslope analysis and basin-fill implications in the Westphalian A-C of Great Britain. Journal of the Geological Society, London 153: 881-900.

Rolfe, W.D.I., 1980. Early invertebrate terrestrial faunas. In: Panchen, A.L. (ed.): The terrestrial environment and the origin of land vertebrates. Systematics Association Special Volume 15: 117-157.

Roscher, M. \& Schneider, J.W., 2005. An annotated correlation chart for continental late Pennsylvanian and Permian basins and the marine scale. In: Lucas, S.G. \& Ziegler, K.E. (eds): The non-marine Permian. Bulletin of the New Mexico Museum of Natural History and Science 30: 282-291.

Rösler, J., Pälchen, W., Odssenkopf, W. \& Taubert, P., 1967. Die Kohlentonsteine aus den Steinkohlenbecken von Zwickau-Ölsnitz, Freital-Döhlen (bei Dresden) und Doberlug. Freiberger Forschungshefte C 211: 1-146.

Rothwell, G.W., 1975. The Callistophytaceae (Pteridospermopsida): I. Vegetative structures. Palaeontographica, Abteilung B 151: 176-196.

Rothwell, G.W., 1981. The Callistophytales (Pteridospermopsida). Reproductively sophisticated gymnosperms. Review of Palaeobotany and Palynology 32: 103-121.

Rothwell, G.W., Scheckler, S.E. \& Gillespie, W.H., 1989. Elkinsia gen. nov., a Late Devonian gymnosperm with cupulate ovules. Botanical Gazette 150: 170-189.

Rothwell, G. W. \& Warner, S., 1984. Cordaioxylon dumusum n. sp (Cordaitales). I. Vegetative structures. Botanical Gazette 145: 275-291.

Rothwell, N.R. \& Quinn, P., 1987. The Welton Oilfield. In: Brooks, J. \& Glennie, K. (eds): Petroleum geology of North West Europe. Graham \& Trotter (London): 181-189. 
Rowley, D.B., Raymond, A., Parrish, J.T., Lottes, A.L., Scotese, C.R. \& Ziegler, A.M., 1985. Carboniferous paleogeographic, phytogeographic, and paleoclimatic reconstructions. International Journal of Coal Geology 5: 7-42.

Royer, D.L., Berner, R.A., Montañez, I.P., Tabor, N.J. \& Beerling. D.J., 2009. C02 as a primary driver of Phanerozoic climate. GSA Today 14: 4-10.

Rutkowski, J., 1972. Osady stefanu Górnośląskiego Zagłębia Węglowego. Prace Instytutu Geologicznego 61: 539-556.

Ryan, R.J., Boehner, R.C. \& Calder, J.H., 1991. Lithostratigraphical revisions of the upper Carboniferous to lower Permian strata in the Cumberland Basin, Nova Scotia and the regional implications for the Maritimes Basin in Atlantic Canada. Bulletin of Canadian Petroleum Geology 39: 289-314.

Saunders, W.B. \& Ramsbottom, W.H.C., 1986. The mid-Carboniferous eustatic event. Geology 14: 208-212.

Schäfer, A., 1986. Die Sedimente des Oberkarbons und Unterrotliegenden im Saar-Nahe-Becken. Mainzer Geowissenschaftliche Mitteilungen 15: 239-365.

Schäfer, A., 1989. Variscan molasse in the Saar-Nahe Basin (W-Germany), Upper Carboniferous and Lower Permian. Geologische Rundschau 78: 499-524.

Schäfer, A., 2005. Sedimentologisch-numerisch begründeter Stratigraphischer Standard für das Permo-Karbon des Saar-Nahe-Beckens. In: Deutsche Stratigraphische Kommission, V. (ed.): Stratigraphie von Deutschland V. Das Oberkarbon (Pennsylvanium) in Deutschland. Courier Forschungsinstitut Senckenberg 254: 369-394.

Schäfer, A. \& Korsch, R.J., 1998. Formation and sediment fill of the Saar-Nahe Basin (Permo-Carboniferous, Germany). Zeitschrift der Deutschen Geologischen Gesellschaft 149: 233-269.

Schäfer, A. \& Sneh, A., 1983. Lower Rotliegend fluvio-lacustrine sequences in the Saar-Nahe Basin. Geologische Rundschau 72: 1135-1145.

Scheuvens, D. \& Zulauf, G., 2000. Exhumation, strain location, and emplacement of granitoids along the western part of the Central Bohemian shear zone (Bohemian Massif). International Journal of Geological Sciences 89: 617-630.

Schindler, T. \& Heidtke, V.H (eds), 2007. Kohlensümpfe, Seen und Halbwüsten. Dokumente einer rund 300 Millionen Jahre alten Lebewelt zwischen Saarbrücken und Mainz. POLLICHIA Sonderveröffentlichung 10: 1-318.

Schneider, J.W., Goretzki, J. \& Rößler, R., 2005a. Biostratigraphisch relevante nicht-marine Tiergruppen im Karbon der variscischen. Vorsenke und der Innensenken. Courier Forschungsinstitut Senckenberg 254: 103-118.

Schneider, J.W., Hoth, K., Gaitzsch, B.G., Berger, H.J., Steinborn, H., Walter, H. \& Zeidler, M.K., 2005b. Carboniferous stratigraphy and development of the Erzgebirge Basin, East Germany. Zeitschrift der Deutschen Gesellschaft für Geowissenschaften 156: 431-466.

Schneider, J.W. \& Rößler, R., 1996. A Permian calcic paleosol containing rhizoliths and microvertebrate remains - environment and taphonomy; Erzgebirge basin, Germany. Neues Jahrbuch für Geologie und Paläontologie, Abhandlungen 202: 243-258.

Schneider, J.W., Schretzenmayr, S. \& Gaitzsch, B.G., 1998. Excursion Guide. Rotliegend reservoirs at the margin of the southern Permian Basin. Leipziger Geowissenschaften 7: 15-44.

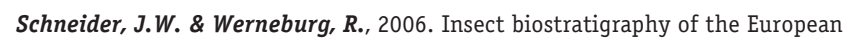
continental Late Pennsylvanian and Early Permian. In: Lucas, S.G., Cassinis, G. \& Schneider, J.W. (eds): Non-marine Permian biostratigraphy and biochronology. Geological Society, London, Special Publication 265: 325-336.
Schneider, J.W., Werneburg, R., Lucas, S.G. \& Béthoux, O., 2003. Insect biochronozones - a powerful tool in the biostratigraphy of the Pennsylvanian and the Permian. Abstracts. XVth International Congress on Carboniferous and Permian Stratigraphy, 10-15 August. Utrecht: 470-473.

Schultka, S. \& Kahlert, E., in press. Zur Makroflora der Zwickau-Formation. Schriftenreihe Bergbau in Sachsen 15.

Schuster, A., 1968. Karbonstratigraphie nach Bohrlochmessungen. Erdöl-Erdgas Zeitschrift 84: 439-457.

Schuster, A., 1971. Die Westfal Profile der Bohrungen Bockraden 1-5 bei Ibbenbüren und ihre Parallelisierung mit dem Bohrprofil Norddeutschland 8 und dem jüngsten Ruhrkarbon nach Bohrlochmessungen. Fortschritte in der Geologie von Rheinland und Westfalen 18: 39-88

Scott, A.C., 1977. A review of the ecology of Upper Carboniferous plant assemblages, with new data from Strathclyde. Palaeontology 20: 447-473.

Scott, A.C., 1978. Sedimentological and ecological control of Westphalian B plant assemblages from West Yorkshire. Proceedings of the Yorkshire Geological Society 41: 461-508.

Scott, A.C., 1979. The ecology of Coal Measure floras from northern Britain. Proceedings of the Geologists' Association 90: 97-116.

Scott, A.C. \& Chaloner, W.G., 1983. The earliest fossil conifer from the Westphalian B of Yorkshire. Proceedings of the Royal Society of London, Series B 220: 163-182.

Scott, A.C., Galtier, J. \& Clayton, G., 1985. A new late Tournaisian (Lower Carboniferous) flora from the Kilpatrick Hills, Scotland. Review of Palaeobotany and Palynology 44: 81-99.

Selter, V., 1990. Sedimentologie und Klimaentwicklung im Westfal C/D und Stefan des nordwestdeutschen Oberkarbon-Beckens. DGMK Berichte 310 (unpublished report).

Šetlík, J., 1977. Results on recent investigation on the Carboniferous flora of Bohemia. In: Holub, V. \& Wagner, R. H. (eds): Symposium on Carboniferous Stratigraphy. Czechoslovakian Geological Survey (Prague): 315-340.

Seward, A.C., 1898. Fossil plants. Volume 1. Cambridge University Press: 452 pp. Shabica C.W. \& Hay A.A. (eds), 1997. The fossil fauna of Mazon Creek. Northeastern Illinois University (Chicago): 308 pp.

Sheil, $\boldsymbol{D}$. \& Murdiyarso, $\boldsymbol{D}$., 2009. How forests attract rain: an examination of a new hypothesis. BioScience 59: 341-347.

Shukla, J., Nobre, C. \& Sellers, P., 1990. Amazon deforestation and climate change. Science 247: 1322-1325.

Shulga, W.F., Zdanowski, A., Zaytseva, L.B., Ivanova, A.W., Korol, N.D., Kotasowa, A., Kotas, A., Kostik, I.E., Lelik, B.I., Migier, T., Manitshev, W.I., Matrofailo, M.N., Ptak, B., Savtchuk, W.S., Sedaeva, G.M. \& Stepanenko, J.G., 2007. Correlation of the Carboniferous coal-bearing formations of the Lviv-Volyn and Lublin basins. (in Russian, English summary). Kiev (National Academy of Sciences of Ukraine, and the Institute of Geological Sciences, Polish State Geological Institute - Upper Silesian Branch: 428 pp.

Shute, C.H. \& Cleal, C.J., 2002. Ecology and growth habit of Laveineopteris: a gymnosperm from the Late Carboniferous tropical rain forests. Palaeontology 45: 943-972.

Siedlecki, S., 1951. Utwory stefańskie i permskie we wschodniej części Polskiego Zagłębia Węglowego. Acta Geologica Polonica 2, 300-348.

Šimůnek, Z., 1988. Varieties of the species Alethopteris grandinioides Kessler from the Kladno Formation (Westphalian C, D, Bohemia). Casopis pro mineralogii a geologii 33: 381-394. 
Šimůnek, Z., 1994. Megaflora of tuffaceous interbeds in coal seams of the Nýřany Member (Westphalian D) at the Dobré štěstí Mine in the Plzeň Basin (Czech Republic). Vest. Cesk. geol. œst., 69, 31-46.

Šimůnek, Z., 2007a. Cuticlular analysis of medullosalean pteridosperms from the Radnice Member (Pennsylvanian) of the Central and Western Bohemian basins (Czech Republic). In: Wong, Th.E. (ed.): Proceedings of the $\mathrm{XV}^{\text {th }}$ International Congress on Carboniferous and Permian Straigraphy. Utrecht, the Netherlands, 10-16 August. Royal Netherlands Academy of Arts and Sciences (Amsterdam): 389-402.

Šimůnek, Z., 2007b. New classification of the genus Cordaites from the Carboniferous and Permian of the Bohemian Massif, based on cuticle micromorphology. Sborník Národního Muzea v Praze, Serie B, Přírodní Vědy 62: 97-210.

Skoček, V., 1990. Stephanian lacustrine-deltaic sequence in central and northeastern Bohemia (in Czech with English summary). Sborník geologických věd, Rada Geologie 45: 91-122.

Skoček, V., 1993. Fossil calcretes in the Permocarboniferous sequences; Bohemian Massif, Czechoslovakia. Véstník Českého geologického ústavu 68: 45-51.

Skoček, V. \& Holub, V., 1968. Origin, age and characteristics of fossil Late Palaeozoic weathering residues in the Bohemian Massif. Sborník geologických věd, Rada Geologie 14: 3-46.

Skopec, J., Pešek, J. \& Kobr, M., 2000. Fosilní říční sít na svrchu slánského souvrství v mšensko-roudnické pánvi. Uhlí rudy geologický průzkum 5: 3-11.

Smith, A.H.V., 1962. The palaeoecology of Carboniferous peats based on the miospores and petrography of bituminous coals. Proceeding of Yorkshire Geological Society 33: 423-474.

Smith, A.H.V. \& Butterworth, M.A., 1967. Miospores in the coal seams of the Carboniferous of Great Britain. Special Papers in Palaeontology 1: 1-324.

Stampfli, G.M. \& Borel, G.D., 2004. The TRANSMED Transects in Space and Time: constraints on the paleotectonic evolution of the Mediterranean Domain. In: Cavazza, W., Roure, F., Spakman, W., Stampfli, G.M. \& Ziegler P. (eds): The TRANSMED Atlas: the Mediterranean Region from Crust to Mantle. Springer Verlag (Heidelberg): 53-80.

Stead, J.T.G., 1974. The sedimentology of the Upper Coal Measures of the Forest of Dean and adjacent areas. Unpublished Ph. D. Thesis, University of Wales, Swansea.

Sternberg, K.M., 1838. Versuch einer geognostisch-botanischen Darstellung der Flora der Vorwelt., Volume 2, Parts 7-8. G. Hässe und Söhne (Prague): 81-220.

Stewart, W.N. \& Rothwell, G.W., 1993. Paleobotany and the evolution of plants (2nd edition). Cambridge University Press: $521 \mathrm{pp}$.

Stidd, B.M., 1974. Evolutionary trends in the Marattiales. Annals of the Missouri Botanical Gardens 61: 388-407.

Stille, H., 1924. Grundfragen der vergleichenden Tektonik. Borntraeger (Berlin): $324 \mathrm{pp}$.

Streel, M., Somers, Y. \& Dusar, M., 2008. The miospores of the Westphalian C / Westphalian D transition in the Campine Basin (Belgium) in the context of the macroflora zonations. Geologica Belgica 11: 243-250.

Strehlau, K., 1990. Facies and genesis of Carboniferous coal seams of Northwest Germany. International Journal of Coal Geology 15: 245-292.

Süss, M.P., 1996. Sedimentologie und Tektonik des Ruhr-Beckens: Sequenzstratigraphische Interpretation und Modellierung eines Vorlandbeckens der Varisziden. Doktorate Thesis, Rheinische Friedrich-Wilhelms-Universität, Bonn.
Süss, M.P., 2005. Zyklotheme, Zyklen und Sequenzen Steuernde Faktoren der Sedimentation im Ruhr-Becken. In: Deutsche Stratigraphische Kommission (ed.): Stratigraphie von Deutschland - Das Oberkarbon (Pennsylvanium) in Deutschland. Courier Forschungsinstitut Senckenberg 254: 161-168

Süss, M.P., Drozdzewski, G. \& Schäfer, A., 2000. Sequenzstratigraphie des kohleführenden Oberkarbons im Ruhr-Becken. Geologisches Jahrbuch A 156: 45-106.

Süss M.P., Drozdzewski, G. \& Schäffer, A., 2007. Sedimentary environment dynamics and the formation of coal in the Pennsylvanian Variscan foreland in the Ruhr Basin (Germany, Western Europe). International Journal of Coal Geology 69: 267-287.

Talens, J. \& Wagner, R.H., 1995. Stratigraphic implications of Late Carboniferous and Early Permian megafloras in Lérida, south-central Pyrenees; Comparison with the Cantabrian Mountains. Coloquios de Paleontologia 47: 177-192.

Tandon, S.K. \& Gibling, M.R., 1997. Calcretes at sequence boundaries in Upper Carboniferous cyclothems of the Sydney Basin, Atlantic Canada. Sedimentary Geology 112: 43-67.

Tásler, R., Čadková, Z., Dvořák, J., Fediuk, F., Chaloupský, J., Jetel, J., Kaiserová-Kalibová, M., Prouza, V., Schovánková-Hrdličková, D., Středa, J., Strída, M. \& Šetlík, J., 1979. Geology of the Bohemian part of the IntraSudetic Basin. Academie (Prague): 296 pp. (in Czech with English Summary).

Taylor, T.N., 1969. On the structure of Bowmanites dawsonii spores. Palaeontographica, Abteilung B 125: 65-72.

Taylor, T.N., 1970. The morphology of Bowmanites dawsonii spores. Micropaleontology 16: 243-248.

Taylor, W.A., 1986. Ultrastructure of sphenophyllalean spores. Review of Palaeobotany and Palynology 47: 105-128.

Tenchov, Y.G., 1976. Composition pecularities of the Carboniferous flora of the Svoge Basin, West Bulgaria. Geologica Balcanica 6: 3-11.

Tenchov, Y.G., 1987. Fosilite na Balgariya. I (1) Paleozoi fosilna flora. Megaflora. 1. Chlenestostableni i lepidofiti. Bulgarian Academy of Sciences (Sofia): $165 \mathrm{pp}$.

Tenchov, Y.G., 1989. Possible position of the Variscan chains between the Balkan and Caucasus. Geologica Balcanica 19(3): 3-7.

Tenchov, Y., 1993. Sedimentation and erosion during the Late Carboniferous in the Dobrudzha coal field (northeast Bulgaria). Geologica Balcanica 23: 3-18.

Tenchov, Y.G., 2004a. The Rakovski Formation (Carboniferous, NE Bulgaria) stratigraphy, sedimentary conditions and interpretation. Geologica Balcanica 34: 85-96.

Tenchov, Y.G., 2004b. The genus Lonchopteris Brongniart in the Dobrudzha Carboniferous Basin, Bulgaria. Geologica Balcanica 34: 97-104.

Tenchov, Y.G., 2005. Early Westphalian sediments of Dobrudzha Coalfield (NE Bulgaria) - an interpretation of their stratigraphy and sedimentation conditions. Zeitschrift der Deutschen Gesellschaft für Geowissenschaften 156: 467-480.

Tenchov, Y.G., 2007a. The Carboniferous of Svoge Coalfield (Bulgaria). Geologica Balcanica 36; 5-15.

Tenchov, Y.G., 2007b. Late Westphalian and early Stephanian sediments of the Dobrudzha Coalfield, NE Bulgaria. Geological Magazine 144: 497-511.

Tenchov, Y., 2007c. Carboniferous megaflora composition peculiarities of Svoge and Dobrudzha coalfield, Bulgaria. Abstracts, IGCP 469 Meeting (Leiden).

Tenchov, Y.G. \& Kulaksuzov, G., 1972. Litostratigrafiya na gorniya Karbon ot Dobrudzhanskiya vaglishten baseyn. Izvestiya na Geologicheskiya Institut, Seriya Stratigrafiya i Lithologiya 21: 41-62. 
Tenchov, Y.G. \& Popov, A.B., 1987. The genus Linopteris Presl (Late Carboniferous) in Dobrudza Coal Basin. Geologica Balcanica 17: 15-32.

Tenchov, Y.G. \& Popov, A.B., 1991. Morphogenetical transition between genera Neuropteris (Brongniart) and Reticulopteris Gothan in Dobrudza Coal Basin. Geologica Balcanica 20: 41-51.

Thomas, B.A., 1978. New records of Carboniferous lycopod cones. Geological Journal 13: 11-14.

Thomas, B.A., 1997. Upper Carboniferous herbaceous lycopsids. Review of Palaeobotany and Palynology 95: 129-153.

Thomas, B.A., 2005. A reinvestigation of Selaginella species from the Asturian of the Zwickau coalfield, Germany and their assignment to the new sub-genus Hexaphyllum. Zeitschrift der Deutschen Gesellschaft für Geowissenschaften 156: 1-12.

Thomas, B.A., 2007. Phytogeography of Asturian (Westphalian D) lycophytes throughout the Euramerican belt of coalfields. Geological Magazine 144: 457463.

Thomas, B.A. \& Cleal, C.J., 1994. Plant fossils from the Writhlington Nature Reserve. Proceedings of the Geologists' Association 105: 15-32.

Thomas, B.A. \& Tenchov, Y., 2004. The Upper Westphalian lycophyte floras of the Dobrudzha Coalfield (Bulgaria) and a comparison with those of southern Britain and Cape Breton (Canada). Geologica Balcanica 34: 105-110.

Torsvik, T.H. \& Cocks, R.M., 2004. Earth geography from 400 to 250 Ma: a palaeomagnetic, faunal and facies review. Journal of the Geological Society, London 161: 555-572.

Trotter, F.M., 1942. Geology of the Forest of Dean coal and ironstone field (Part). Memoirs of the Geological Survey U.K. (London): $95 \mathrm{pp.}$

Uhl, D. \& Cleal, C.J., in press. Late Carboniferous vegetation change in lowland and intramontane basins in Germany. International Journal of Coal Geology.

Valterová, P., 1979. Paleopalynologicko-stratigrafický výzkum českého křídla vnitrosudetské pánve. MSc Thesis, Prague.

Van Adrichem Boogaert, H.A. \& Kouwe, W.F.P., 1993. Stratigraphic nomenclature of the Netherlands, revision and update by RGD and NOGEPA. Mededelingen Rijks Geologische Dienst 50: sections A-J.

Van Amerom, H.W.J., 1996. The biostratigraphy of borehole 'De Lutte-6' (East Twente, the Netherlands). Mededelingen Rijks Geologische Dienst, Nieuwe Serie 55: 83-98.

Van Amerom, H.W.J. \& Pagnier, H.J.M., 1990. Palaeoecological studies of Late Carboniferous plant macrofossils from Borehole Kemperkoul-1 (Sittard, the Netherlands). Mededelingen Rijks Geologische Dienst, Nieuwe Serie 44-4: 1-19.

Van Buggenum, J.M. \& Den Hartog Jager, D.C., 2007. Silesian. In: Wong, Th.E., Batjes, D.A.J. \& de Jager, J.: Geology of the Netherlands. Royal Netherlands Academy of Arts and Sciences: 43-62.

Van der Laar, J.G.M. \& Van der Zwan, C.J., 1996. Palynostratigraphy and palynofacies reconstruction of the Upper-Carboniferous of borehole De Lutte- 6 (East Twente, the Netherlands). Mededelingen Rijks Geologische Dienst 55: 61-82.

Van der Meer, M. \& Pagnier, H., 1996. Sediment petrography of sandstone bodies of borehole 'De Lutte-06' (East Twente, the Netherlands) and its regional significance. Mededelingen Rijks Geologische Dienst, 55: 31-60.
Van der Zwan, C.J., Van der Laar, J.G.M., Pagnier, H.J.M. and Van Amerom, H.J.W., 1993. Palynological, ecological and climatological synthesis of the upper Carboniferous of the well De Lutte-6 (East Netherlands). Comptus Rendus XII International Conference on the Carboniferous and Permian 1: 167-186.

Van Hoof, T.B., Abbink, O.A., van Waveren, I.M. \& Van Konijnenburg-van Cittert, J.H.A., 2007. Revision of the palaeobotanical and palynological interpretation of the Late Carboniferous interval of the De Lutte- 6 well, the Netherlands. CIMP Lisbon Abstracts: 103.

Van Waveren, I.M., Abbink, O.A., Van Hoof, T.B. \& Van Konijnenburg-van Cittert, J.H.A., 2008. Revision of the late Carboniferous megaflora from the De Lutte-06 well (Twente, the Netherlands), and its stratigraphical implications. Netherlands Journal of Geosciences 87: 339-352.

Vasey, G.M., 1994. Classification of Carboniferous non-marine bivalves: systematics versus stratigraphy. Journal of the Geological Society 151: 1023-1033.

Vasey, G.M. \& Bowes, G.E., 1985. The use of cluster analysis in the study of some non-marine bivalvia from the Westphalian D of the Sydney Coalfield, Nova Scotia, Canada. Journal of the Geological Society 142: 397-410.

Vasey, G.M. \& Zodrow, E.L., 1983. Environmental and correlative significance of a non-marine algal limestone (Westphalian D), Sydney Coalfield, Cape Breton Island, Nova Scotia. Maritime Sediments and Atlantic Geology 19: 1-10.

Wagner, R.H., 1974. The chronostratigraphic units of the Upper Carboniferous in Europe. Bulletin de la Société Belge de Géologie, de Paléontologie et d'Hydrologie 83: 235-253.

Wagner, R.H., 1977. Comments on the upper Westphalian and Stephanian floras of Czechoslovakia, with particular reference to their stratigraphic age. In: Holub, V.M. \& Wagner, R.H. (eds): Symposium on Carbononiferous Stratigraphy. Geological Survey (Prague): 441-457.

Wagner, R.H., 1998. Consideraciones sobre los pisos de la Serie Estefaniense. Monografias de la Academia de Ciencias, Exactas Físicas, Químicas y Naturales de Zaragoza 13: 9-19.

Wagner, R.H., 2004. The Iberian Massif: a Carboniferous assembly. Journal of Iberian Geology 30: 93-108.

Wagner, R.H. \& Alvarez-Vázquez, C., 1991. Floral characterisation and biozones of the Westphalian D Stage in NW Spain. Neues Jahrbuch für Geologie und Paläontologie, Abhandlungen 183: 171-202.

Wagner, R.H., Fernandez-Garcia, L. \& Eagar, R.M.C., 1983. Geology and palaeontology of the Guardo Coalfield (NE León - NW Palencia), Cantabrian Mts. Instituto Geologico y Minero de España (Madrid): 109 pp.

Wagner, R.H. \& Lemos de Sousa, M.J., 1983. The Carboniferous megafloras of Portugal - a revision of identifications and discussion of stratigraphic ages. In: Lemos de Sousa, M.J. \& Oliviera, J.T. (eds): The Carboniferous of Portugal. Memórias dos Serviços Geológicos de Portugal 29, 127-152.

Wagner, R.H. \& Lyons, P.C., 1997. A critical analysis of the higher Pennsylvanian megafloras of the Appalachian region. Review of Palaeobotany and Palynology 95, 255-283.

Wagner, R.H. \& Spinner, E., 1972. The stratigraphic implications of the Westphalian D macro- and microflora of the Forest of Dean Coalfield (Gloucestershire), England. Proceedings of the $24^{\text {th }}$ International Geological Congress 7: 428-437. 
Wagner, R.H. \& Winkler Prins, C.F., 1970. The stratigraphic succession, flora and fauna of Cantabrian and Stephanian A rocks at Barruelo (prov. Palencia), N.W. Spain. In: Streel, M. \& Wagner, R.H. (eds): Colloque sur la stratigraphie du Carbonifère. Les Congrès et Colloque de l'Université de Liège 55: 487-551.

Wagner, R.H. \& Winkler Prins, C.F., 1979. The lower Stephanian of Western Europe. Palaeontological characteristics of the main subdivisions of the Carboniferous. Compte rendu $8^{\mathrm{e}}$ Congrès International de Stratigraphie et de Géologie du Carbonifère (Moscow, 1975) 3: 111-140.

Wagner, R.H. \& Winkler Prins, C.F., 1985. Stratotypes of the two lower Stephanian stages, Cantabrian and Barruelian. Compte rendu $10^{\mathrm{e}}$ Congrès International de Stratigraphie et de Géologie du Carbonifère (Madrid, 1983) 4: 473-483.

Wagner, R.H. \& Winkler Prins, C.F., 2002. Tectonics vs. cyclothems: Carboniferous sedimentation in the Cantabrian Mountains, Spain. In: Hill, L.V., Henderson, C.H. \& Bamber, E.W. (eds): Carboniferous and Permian of the world, Proceedings of the XIV ICCP. Canadian Society of Petroleum Geologists Memoir 19: 228-238.

Waksmundzka M.I., 2005. Ewolucja facjalna i analiza sekwencji w paralicznych utworach karbonu z północno-zachodniej i centralnej Lubelszczyzny. Unpublished Ph.D. thesis. Polish Geological Institute, Warsaw.

Waksmundzka, M.I. \& Ptak, B., 2006. Depositional environments and petrographical characteristics of the Namurian and Westphalian coals in the Lublin Carboniferous Basin, SE Poland. Abstracts, IGCP 469 - Late Variscan terrestrial biotas and palaeoenvironments (Kraków): 25-29.

Walton, J., 1936. On the factors which influence the external form of fossil plants; with descriptions of the foliage of some species of the Palaeozoic equisetalean genus Annularia Sternberg. Philosophical Transactions of the Royal Society of London, Series B 226: 219-237.

Ward, P., Labandeira, C., Laurin, M. \& Berner, R.A., 2006. Confirmation of Romer's Gap as a low oxygen interval constraining the timing of initial arthropod and vertebrate terrestrialization. Proceedings of the National Academy of Sciences of the United States of America 103: 16818-16822.

Warr, L.N., 2000. The Variscan Orogeny: the welding of Pangea. In: Woodcock, N. \& Strahan, R. (eds): Geological history of Britain and Ireland. 0xford (Blackwell): 271-294.

Wartmann, R., 1969. Studie über die papillen-förmigen Verdickungen auf der Kutikule bei Cordaites an Material aus dem Westfal C des Saar-Karbons. Argumenta Palaeobotanica 3: 199-207.

Waters, C.N., Browne, M.A.E., Dean, M.T. \& Powell, J.H., 2007. Lithostratigraphical framework for Carboniferous secessions in Great Britain (onshore). British Geological Survey Research Report RR/07/01: 1-60.

Waters, C.N. \& Davies, S.J., 2006. Carboniferous: extensional basins, advancing deltas and coal swamps. In: Brenchley, P.J. \& Rawson, P.F. (eds): The geology of England and Wales. London (The Geological Society): 173-223.

Waters, C.N., Waters, R.A., Barclay, W.J. \& Davies, J.R., 2009. A lithostratigraphical framework for the Carboniferous successions of southern Great Britain (onshore). British Geological Survey Research Report RR/09/01: 1-184.

Webb, T.J., Gaston, K.J., Hannah, L. \& Woodward, F.I., 2006. Coincident scales of forest feedback on climate and conservation in a diversity hotspot. Proceedings ofthe Royal Society, London, Series B 273: 757-765.

Weiss, C.E., 1884. Beitrage zur fossilen Flora. III Steinkohlen-Calamarien. II. Abhandlungen zur Geologische Spezialkarte von Preussen und den Thüringischen Staaten 5: 1-203.
Weithofer, K.A., 1896. Die geologischen Verhältnisse des Bayer-Schachtes und benachbarten Teiles der Pilsner Kohlenmulde. Österreichische Zeitschrift für Berg- und Hüttenwesen 44(25-28): 317-321, 331-335, 345-349, 355-357.

Weithofer, K.A., 1902. Geologische Skizze des Kladno-Rakonitzer Kohlenbeckens. Verhandlungen der Kaiserlich-Königlich Geologischen Reichsanstalt: 399-420.

White, $\boldsymbol{D}$. \& Thiessen, $\boldsymbol{R} ., 1913$. The origin of coal. Bulletin of the U.S. Bureau of Mines 38: 1-390.

White, J.C., Gibling, M.R. \& Kalkreuth, W.D., 1994. The Backpit seam, Sydney Mines Formation, Nova Scotia: a record of peat accumulation and drowning in a Westphalian coastal mire. Palaeogeography, Palaeoclimatology, Palaeoecology 106: 223-239.

Wightman, W.G., Scott, D.B., Medioli, F.S. \& Gibling, M.R., 1994. Agglutinated foraminifera and thecamoebians from the Late Carboniferous Sydney coalfield, Nova Scotia: paleoecology, paleoenvironments and paleogeographical implications. Palaeogeography, Palaeoclimatology, Palaeoecology 106: 187-202.

Williamson, W.C., 1871. On the organization of Volkmannia dawsonii, an undescribed verticillate strobilus from the lower Coal Measures of Lancashire. Memoirs of the Manchester Literary and Philosophical Society 5: 28-40.

Winchester, T.C., Pharaoh, T.C., Verniers, J., Ioane, D. \& Seghedi, A., 2006. Palaeozoic accretion of Gondwana-derived terranes to the East European Craton: recognition of detached terrane fragments dispersed after collision with promontories. In: Gee, D.G. \& Stephenson, R.A. (eds): European lithosphere dynamics. Geological Society, London, Memoirs 32: 323-332.

Witzmann, F., Kahlert, E. \& Schultka, S., (in press). Zur Makrofauna der Zwickau-Formation. Schriftenreihe Bergbau in Sachsen 15.

Wnuk, C. \& Pfefferkorn, H.W., 1984. The life habits and paleoecology of Middle Pennsylvanian medullosan pteridosperms based on an in situ assemblage from the Bernice Basin (Sullivan County, Pennsylvania, U.S.A.). Review of Palaeobotany and Palynology 41: 329-351.

Woodland, A.W., Evans, W.B. \& Stephens, J.V., 1957. Classification of the Coal Measures of South Wales with special reference to the Upper Coal Measures. Bulletin of the Geological Survey of Great Britain 13: 6-13.

Worssam, B.C., 1963. The stratigraphy of the Geological Survey Upton Borehole, 0xfordshire. Bulletin of the Geological Survey of Great Britain 20: 107-162.

Wrede, V. \& Ribbert, K.-H., 2005. Das Oberkarbon (Silesium) am Nordrand des rechtsrheinischen Schiefergebirges (Ruhrkarbon). In: Deutsche Stratigraphische Kommission (ed.): Stratigraphie von Deutschland - Das Oberkarbon (Pennsylvanium) in Deutschland. Courier Forschungsinstitut Senckenberg 254: 225-254

Wrede, V. \& Zeller, M., 2005. Eifelnordrand, Aachen-Erkelenz und Untergrund der Niederrheinischen Bucht. In: Deutsche Stratigraphische Kommission (ed.): Stratigraphie von Deutschland - Das Oberkarbon (Pennsylvanium) in Deutschland. Courier Forschungsinstitut Senckenberg 254: 199-224

Zdanowski, A., 2007. Rozpoznanie złóż węgla kamiennego i boksytów w Lubelskim Zagłębiu Węglowym. Biuletyn Państwowego Instytutu Geologicznego 422: 35-50.

Zdanowski, A. \& Żakowa, H., 1995. The Carboniferous System in Poland. Prace Pañstwowego Instytutu Geologicznego 148: 1-215.

Zeiller, $R_{.}, 1894$. Sur les subdivisions du Westphalien de la France d'après les caractères de la flore. Bulletin de la Société Géologique de France 22: 483. 
Zherikhin, V.V., 2002. Ecological history of terrestrial insects. In: Rasnitsyn, A.P. \& Quicke, D.L.J. (eds): History of insects. Kluwer (Dordrecht): 331-388.

Ziegler, P.A., 1990. Geological atlas of western and central Europe. Shell (The Hague): $239 \mathrm{pp}$.

Ziegler, P.A. \& Dézes, P., 2006. Crustal evolution of Western and Central Europe. In: Gee, D.G. \& Stephenson, R.A. (eds): European lithosphere dynamics. Geological Society, London, Memoirs 32: 43-56.

Ziegler, A.M., Hulver, M.I. \& Rowley, D.B., 1997. Permian world topography and climate. In: Martini, I.P. (ed.): Late Glacial and post-Glacial environmental changes - Quarternary, Carboniferous-Permian and Proterozoic. Oxford University Press: 111-146.

Zodrow, E.L., 1985. Odontopteris Brongniart in the Upper Carboniferous of Canada. Palaeontographica, Abteilung B 196: 79-110.

Zodrow, E.L., 1989. Revision of Silesian sphenophyll biostratigraphy of Canada. Review of Palaeobotany and Palynology 58: 177-195.

Zodrow, E.L., 1991. A coal-sulfur model for Sydney Coalfield (Upper Carboniferous), Nova Scotia, Canada. Atlantic Geology 27: 127-142.

Zodrow, E.L., 2002. The 'medullosalean forest' at the Lloyd Cove Seam (Pennsylvanian, Sydney Coalfield, Nova Scotia, Canada). Atlantic Geology 38: 178-195.

Zodrow, E.L., 2007. Reconstructed tree fern Alethopteris zeilleri (Carboniferous, Medullosales). International Journal of Coal Geology 69: 68-89.

Zodrow, E.L. \& Cleal, C.J., 1985. Phyto- and chronostratigraphical correlations between the late Pennsylvanian Morien Group (Sydney, Nova Scotia) and the Silesian Pennant Measures (South Wales). Canadian Journal of Earth Sciences 22: $1465-1473$.

Zodrow, E.L. \& Cleal, C.J., 1998. Revision of the pteridosperm foliage Alethopteris and Lonchopteridium (Upper Carboniferous), Sydney Coalfield, Nova Scotia, Canada. Palaeontographica, Abteilung B 247: 65-122.

Zodrow, E.L. \& McCandish, K., 1980. Upper Carboniferous fossil flora of Nova Scotia. Nova Scotia Museum (Halifax, N.S., Canada): 275 pp.

Zodrow, E.L., Šimůnek, Z., Cleal C.J., Bek, J. \& Pšenička, J., 2006. Taxonomic revision of the Palaeozoic marattialean fern Acitheca Schimper. Review of Palaeobotany and Palynology 138: 239-280.

Zulauf, G., Dörr, W., Fiala, J., Kotková, J., Maluski, H. \& Valverde-Vaquero, P., 2002a. Evidence for high-temperature diffusional creep preserved by rapid cooling of lower crust (North Bohemian shear zone, Czech Republic). Terra Nova 14: 343-354.

Zulauf, G., Bues, C., Dörr, W. \& Vejnar, Z., 2002b. $10 \mathrm{~km}$ minimum throw along the West Bohemian shear zone: Evidence for dramatic crustal thickenning and high topography in the Bohemian Massif (European Variscides). International Journal of Earth Sciences 91: 850-864. 